FABIANA DA ROCHA CLETO

\title{
REFERENCIAIS TECNOLÓGICOS PARA A CONSTRUÇÃO DE EDIFÍCIOS
}

Dissertação apresentada à Escola Politécnica da Universidade de São Paulo para obtenção do Título de Mestre em Engenharia. 


\section{REFERENCIAIS TECNOLÓGICOS PARA A CONSTRUÇÃO DE EDIFÍCIOS}

Dissertação apresentada à Escola Politécnica da Universidade de São Paulo para obtenção do Título de Mestre em Engenharia.

Área de Concentração:

Engenharia de Construção Civil e Urbana

Orientador:

Prof. Dr. Francisco Ferreira

Cardoso 
À minha família e aos amigos, pelo apoio, incentivo e compreensão nos momentos mais dificeis. 


\section{Agradecimentos}

"A vida coloca na nossa frente algumas pessoas especiais e maravilhosas, sempre nos momentos certos como uma surpresa ou um presente..."

...assim iniciei e terminei o meu mestrado, com o incentivo e com o apoio de pessoas que considero muito e serão, por mim, sempre lembradas...

Agradeço ao prof. Dr. Vanderley John por ter apostado em mim, quando fui sua orientanda de iniciação científica no $3^{\circ}$ ano da EPUSP, me convidando para continuar na Escola e fazer o mestrado...

À profa . Dra. Mércia por ter me convidado a participar da "família" do TGP, grupo no qual me identifiquei com a área de gestão e tecnologia da construção civil...

Ao prof. Dr. Francisco Cardoso, meu grandioso orientador, que desde o início acreditou no meu trabalho, pois sempre que precisei ele esteve ali, me ajudando e cada vez mais me incentivando a continuar meus estudos...muitíssimo obrigada!

Ao prof. Dr. Ercio Thomaz, pelo incentivo para eu iniciar o mestrado, pelas suas importantes contribuições ao estudo e pelo constante apoio...

Ao prof. Dr. Cláudio Mitidieri, que acompanhou toda a minha trajetória no mestrado, contribuindo muito com suas sugestões à pesquisa e me indicando caminhos com sua experiência e paciência...

Ao prof. Dr. Sérgio Leusin e, novamente, à prof ${ }^{a}$. Dra. Mércia pelas valiosas contribuições dadas na minha banca de qualificação, que certamente vieram a enriquecer esse trabalho...

Ao Dr. Raphael Pillegi, da CDHU, agradeço pela atenção e por "abrir as portas" ao meu trabalho...

Ao eng. Michel Bazin, do CSTB, pela atenção e por disponibilizar o material de que precisamos para o estudo dos documentos franceses...

Às amigonas politécnicas Fernanda Schiesari, pela paciência e ajuda nas traduções dos textos em francês, e Mariana Yoshioka, pelos conselhos que contribuíram para a finalização do meu mestrado...

A todos que contribuíram direta ou indiretamente no desenvolvimento desse trabalho, que não se sintam esquecidos se não citados nessa única página apenas...

Aos colegas de trabalho do IPT, Alessandra, Berçot, Cristina, Fúlvio, Julio, Luciana, Maria, Tatiana,

Vera, enfim, a todos pela amizade que torna nosso ambiente de trabalho mais alegre no dia-a-dia...

Às colegas de turma do mestrado, Ana Luiza, Auriciane, Fabiana, Juliana, Manuela, Rosiany, Gabriela e Patrícia...pelas risadas nos momentos de relax e pelos estudos quando necessários...

Ao Yolle...simplesmente uma das melhores "surpresas ou presentes" que vou levar desse mestrado...

Ao meu pai, pela constante força...meu alicerce na vida, em quem tento me espelhar mas que com certeza ainda preciso aprender muito para alcançar sua sabedoria e paciência com tudo e com todos...

À minha mãe, que sempre esteve ao meu lado apesar de todos os problemas enfrentados e de toda a "bagunça" que eu fiz com meus "montes de papéis"...À minha irmã Fernanda, que muitas vezes compreendeu meus "estudos noturnos" no quarto...

À avó Elza, que sempre me incentivou a escrever o meu "livro"... À avó Gracinda e ao avô Albano que dizem que sou "tão estudiosa"...Ao avô Oswaldo que, com certeza, torce por mim lá "de cima"...

A Deus, absoluto e acima de tudo, por me iluminar e colocar essas pessoas na minha vida... 


\section{Resumo}

Os referenciais tecnológicos são documentos técnicos de referência, não normativos, elaborados e consensualizados por agentes da cadeia produtiva, visando à disseminação das boas práticas para o processo de produção de edifícios (planejamento, projeto, execução, uso, manutenção e pós-uso), com o intuito de se obter qualidade e adequado desempenho do produto final, bem como de consolidar e difundir o conhecimento no setor. Documentos como esses já são efetivamente utilizados em diversos países, como modelos de códigos de práticas (model codes ou codes of practices) e guias de práticas recomendadas (best practice guides); enquanto a construção civil brasileira, apesar de algumas iniciativas, ainda está aquém do desejado nessa área. Assim, o objetivo dessa dissertação é analisar, discutir e propor orientações técnicas, metodológicas e institucionais para a elaboração e implementação de referenciais tecnológicos para o setor de edificações no Brasil. Para tanto, faz-se uma pesquisa e caracterização de documentos nacionais, como cadernos de encargos e manuais técnicos, discutindo a estrutura e o conteúdo dos mesmos e mostrando ainda, por meio de um estudo de caso, a aplicação prática de um documento utilizado em habitações de interesse social no Estado de São Paulo (Manual de Controle de Obras e Serviços). Apresentam-se, ainda, alguns documentos estrangeiros, além de um estudo mais detalhado sobre os documentos técnicos utilizados na França (Documents Techniques Unifiés - DTU), discutindo-se a sua adaptação à realidade brasileira. Concluise o trabalho analisando, dentre outros fatores, o conceito de referenciais tecnológicos, seu contexto e interfaces, dando orientações quanto à estrutura e ao conteúdo de documentos desse tipo e citando dificuldades e oportunidades de desenvolvimento e aplicação dos mesmos, bem como a necessidade de ações paralelas, incluindo de natureza institucional, que contribuam para o seu uso prático e efetivo. 


\begin{abstract}
The "technical references" are documents that can be used in different phases of the a building project, with no legal effect as standards or Codes, developed by the agents of the industry, to establish and disseminate best practices for planning, design, execution, use, maintenance and post-use phases, with the aim of to achieve quality and performance of the final product and to consolidate and to broadcast knowledge. Such documents exist in different countries, as the "model codes" or "codes of practices" and the "best practice guides", but this is not the case in Brazil, even though we can find some initiatives in this way. Consequently, the objective of this research is to analyse, discuss and propose technical, methodological and institutional orientations to the implementation of technical references for the building construction sector in Brazil. For this purpose, there is a review of documents such as procurement texts and technical manuals, an analysis of their structures and contents and a deeper examination of the application of the document used in social housing projects in Sao Paulo. Some foreign documents are also analysed, as well as the technical documents model used in France (Documents Techniques Unifiés - DTU), discussing its adaptation to fit Brazilian reality. The conclusion of this work lies in the analysis, amongst other factors, of the concept of technical reference documents, its context and interfaces, bringing orientation concerning their structure and content, and presenting difficulties and opportunities of developing and using them, as well as showing the need of additional actions, including those of institutional nature, that contribute to their practical and effective use.
\end{abstract}




\section{SUMÁRIO}

\section{Resumo}

\section{Abstract}

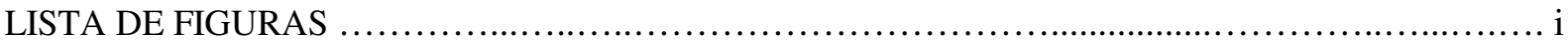

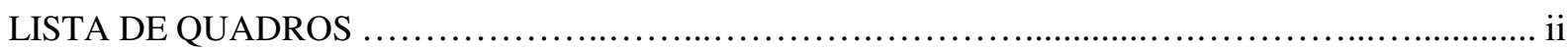

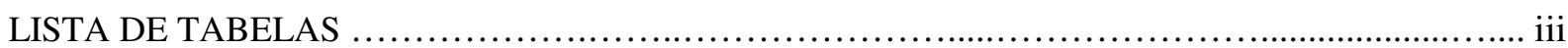

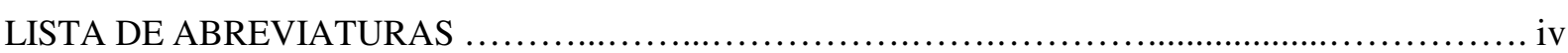

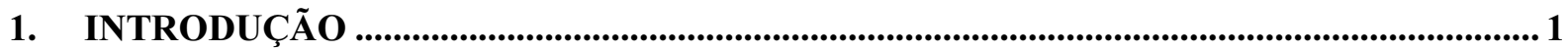

1.1. CONCEITOS IMPORTANTES PARA O ENTENDIMENTO DO TRABALHO …................................... 1

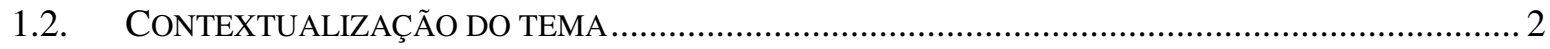

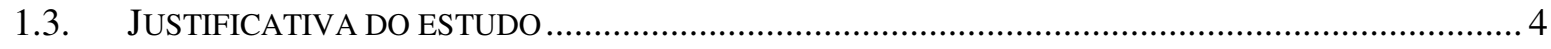

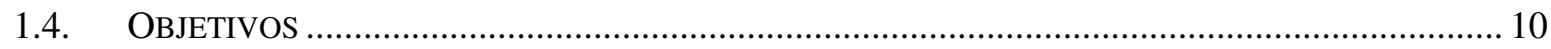

1.5. METOdologia DE DESENVOLVIMENTO DO TRABALHO ….................................................... 11

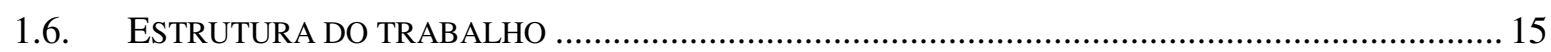

2. INSERÇÃO DE REFERENCIAIS TECNOLÓGICOS NA CONSTRUÇÃO DE EDIFÍCIOS: QUALIDADE, DESEMPENHO E GESTÃO DO CONHECIMENTO ..................... 17

2.1. PROGRAMAS DA QUALIDADE PARA A CONSTRUÇÃO CIVIL E A INTEGRAÇÃO DOS

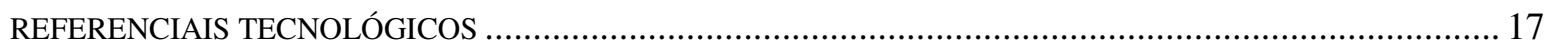

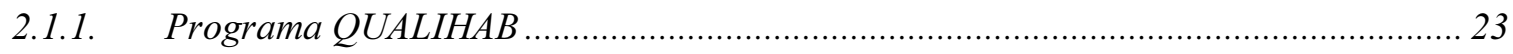

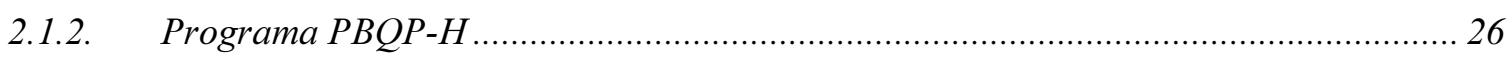

2.2. O CONCEITO DE DESEMPENHO NA CONSTRUÇÃO DE EDIFÍCIOS E O DESENVOLVIMENTO DE

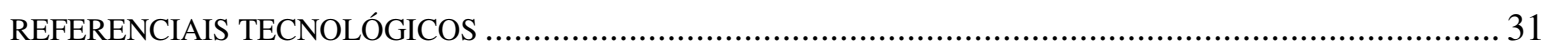

2.3. INTERFACE DOS REFERENCIAIS TECNOLÓGICOS COM A GESTÃO DO CONHECIMENTO NA

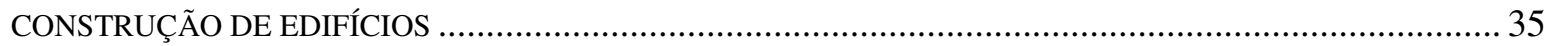

3. REFERENCIAIS TECNOLÓGICOS PARA A CONSTRUÇÃO DE EDIFÍCIOS............... 42

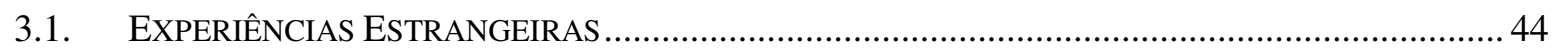

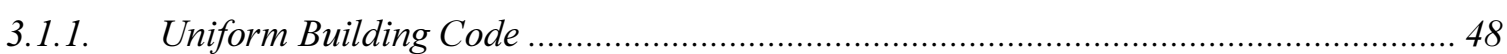

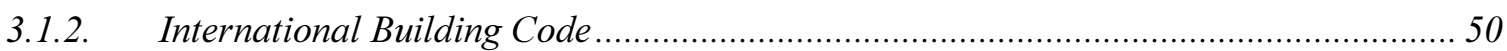

3.1.3. Project Resource Manual - CSI Manual of Practices................................................. 51

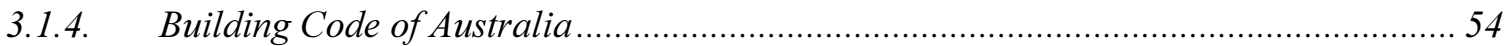




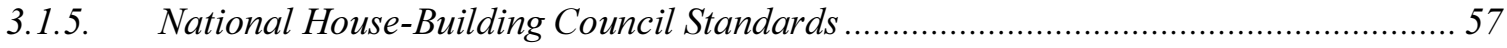

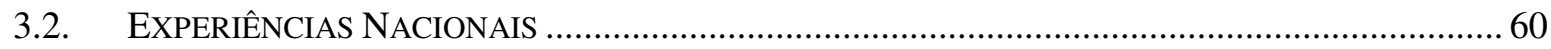

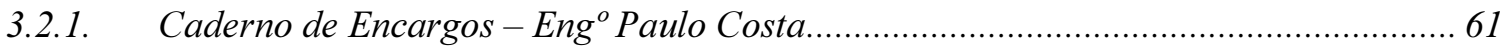

3.2.2. Caderno de Encargos do Governo do Estado do Rio de Janeiro................................... 62

3.2.3. Manual Técnico do DOP - Governo do Estado de São Paulo........................................ 63

3.2.4. Caderno de Encargos - Editora PINI .......................................................................... 65

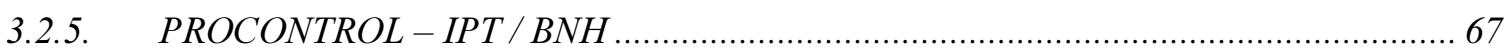

3.2.6. Caderno de Encargos da Prefeitura do Município de São Paulo .................................. 71

3.2.7. Estudos para o controle de qualidade dos componentes, elementos e do produto final

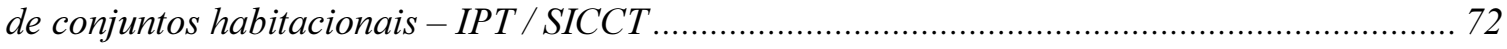

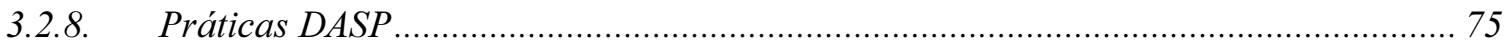

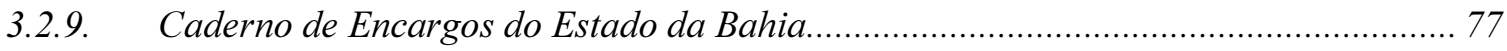

3.2.10. Manual de Obras Públicas - Edificações (Práticas da SEAP) ..................................... 80

3.2.11. Manual Técnico de Engenharia da CAIXA para o Estado de São Paulo ...................... 82

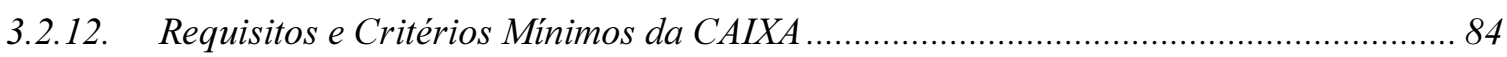

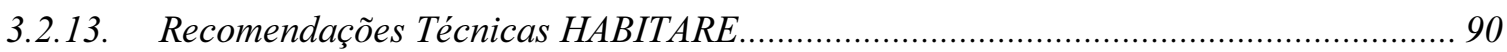

3.2.14. Guia da Qualidade dos Processos Construtivos ........................................................ 92

\section{ESTUDO DOS DOCUMENTOS TÉCNICOS UNIFICADOS (DTU) - EXPERIÊNCIA DO}

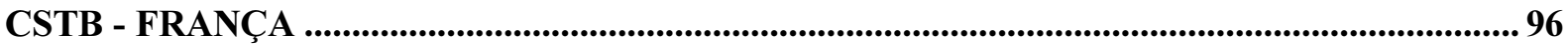

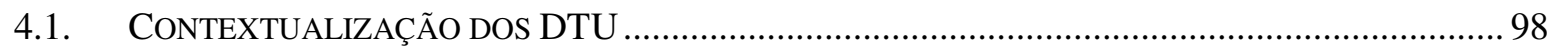

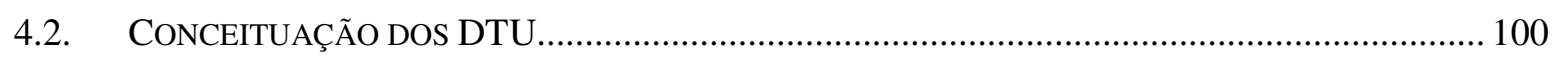

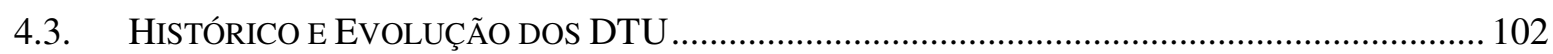

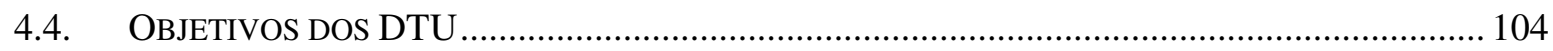

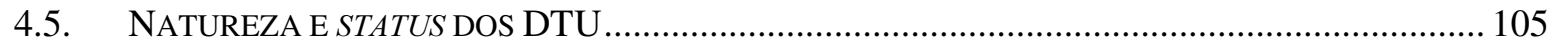

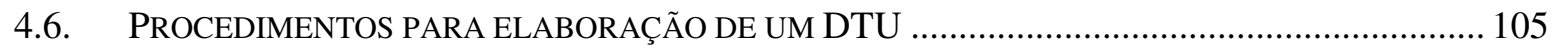

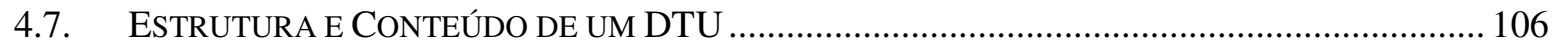

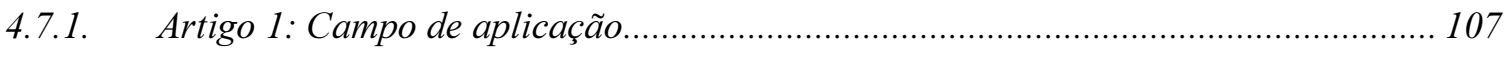

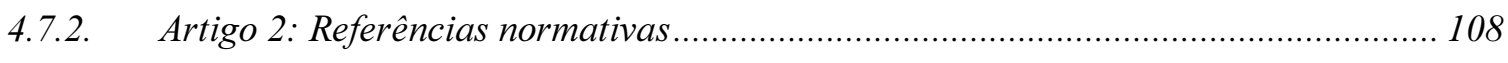

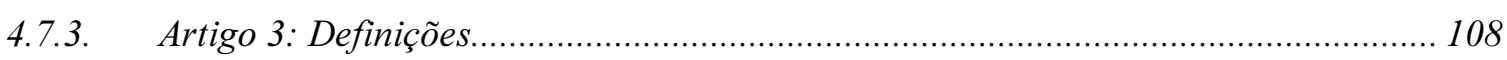

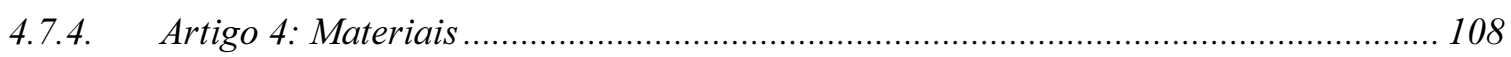

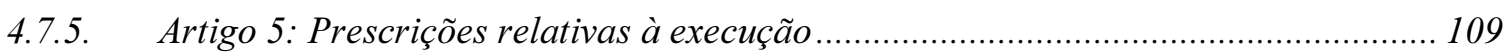

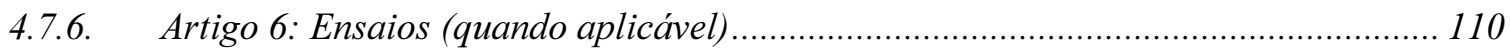

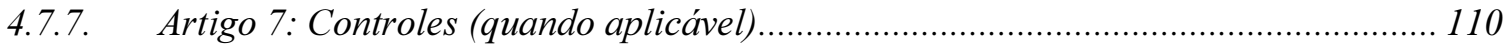

4.7.8. Artigo 8: Condições de início de uso (quando aplicável) ......................................... 110

4.7.9. Artigo 9: Condições de uso normal e de manutenção .............................................. 110 
4.8. VAntagens E Desvantagens do Sistema DTU

4.9. REFLEXÕES SOBRE O CONTEXTO BRASILEIRO E A ADOÇÃO DOS DTU

5. ESTUDO DO MANUAL DE CONTROLE DE OBRAS E SERVIÇOS (MCOS) EXPERIÊNCIA DA CDHU - SÃO PAULO

5.1. CONCEITUAÇÃO DO MCOS E INSERÇÃO NO PROGRAMA QUALIHAB .............................. 120

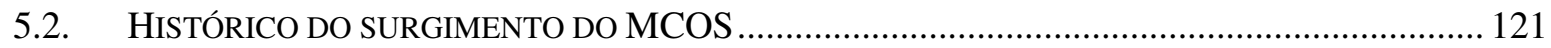

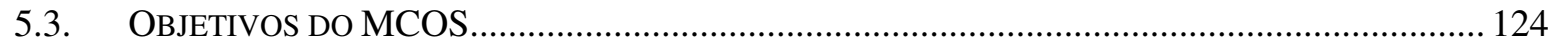

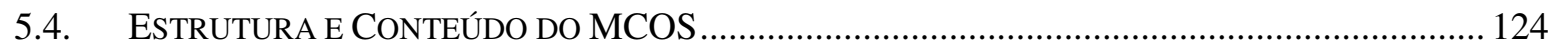

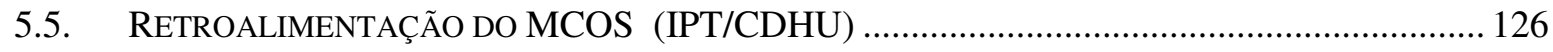

5.6. ANÁLISE DO CONTEÚDO DO MCOS À LUZ DA APLICAÇÃO PRÁTICA …................................. 127

5.7. OPINIÃO DE UM CONSTRUTOR SOBRE O MCOS ................................................................... 135

5.8. PROCESSO DE APRIMORAMENTO DO MCOS ................................................................... 139

6. ANÁLISES E DISCUSSÕES SOBRE REFERENCIAIS TECNOLÓGICOS PARA A

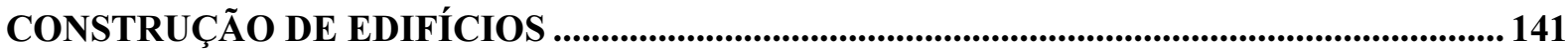

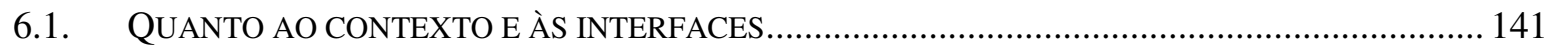

6.2. QUANTO AO CONCEITO DE REFERENCIAIS TECNOLÓGICOS ................................................ 143

6.3. QUANTO AO CONTEÚDO E À ESTRUTURA DOS DOCUMENTOS ............................................ 146

6.4. QUANTO À ELABORAÇÃO E IMPLEMENTAÇÃO DOS REFERENCIAIS TECNOLÓGICOS: ASPECTOS

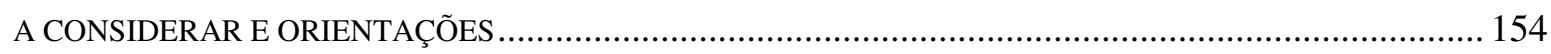

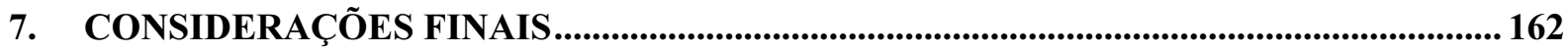

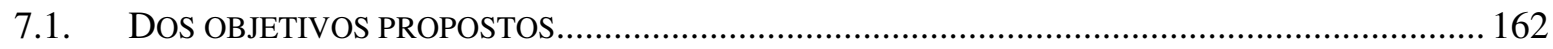

7.2. DAS RECOMENDAÇÕES PARA TRABALHOS FUTUROS ........................................................ 163

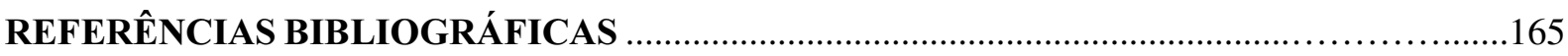

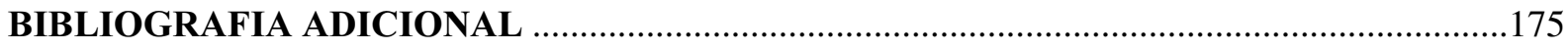

ANEXO A - Manual de Controle de Obras e Serviços - Desvios e Tolerâncias Admitidas: Serviço de Alvenaria Estrutural.

APÊNDICE A - Resumo das constatações apontadas nas vistorias às obras: serviço de alvenaria estrutural

APÊNDICE B - Proposta de base para estrutura de um modelo de documento técnico de referência para a construção de edifícios 


\section{LISTA DE FIGURAS}

Figura 1- Distribuição percentual de normas do CB-02 por tipo. (Fonte: Sanchez, 2003) 7

Figura 2 - Distribuição percentual de normas do CB-02 por idade. (Fonte: Sanchez, 2003) .... 8

Figura 3 - Representação gráfica da metodologia do presente estudo.

Figura 4 - Inserção dos referenciais tecnológicos nos Programas da Qualidade.

Figura 5 - Árvore do conhecimento elaborada pelo CDCON. (Fonte: http://www.cdcon.ufjf.br/ projeto/aconhecimento.php)

Figura 6 - Representação simplificada das etapas do processo de produção de um edifício. .43

Figura 7 - Estrutura dos Códigos de Edificações nos EUA. (Fonte: William E. Koffel, P.E. Koffel

Associates, Inc. in Code Update: International Building Code NFPA 5000, s.d.).

Figura 8 - Esquema de articulação das informações nos documentos técnicos propostos no

PROCONTROL. (Fonte: IPT, 1981b).

Figura 9 - Modelo de estrutura do Caderno de Cláusulas Técnicas de um DTU. (Fonte: CGNorBât, 2001).......

Figura 10 - Percentual de obras com não-conformidade nos serviços de execução, no Projeto IPT/CDHU. (Fonte: Baseado em IPT, 2004).

Figura 11 - Estrutura de referenciais tecnológicos subdividida por etapas do processo de produção do empreendimento ou da obra. Cada etapa contempla os diversos serviços ou elementos da construção.

Figura 12 - Estrutura de referenciais tecnológicos subdividida por serviços ou elementos da construção. Para cada elemento são contempladas as diversas etapas do processo de produção do empreendimento ou da obra.

Figura 13 - Esquema ilustrativo da leitura dos referenciais tecnológicos por agentes específicos de cada etapa do processo de produção de edifícios, no caso, os projetistas. 


\section{LISTA DE QUADROS}

Quadro 1 - Esquema ilustrativo da estrutura do MCOS. 125

Quadro 2 - Manual de Controle de Obras e Serviços - Desvios e Tolerâncias Admitidas: serviço de

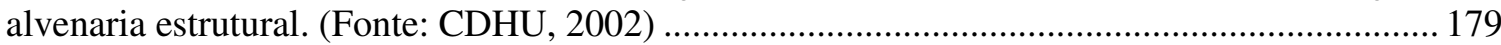

Quadro 3 - Obra A: Vistoria 1. (Fonte: Baseado em IPT, 2004) ........................................................ 182

Quadro 4 - Obra A: Vistoria 2. (Fonte: Baseado em IPT, 2004) ........................................................ 183

Quadro 5 - Obra B: Vistoria 1. (Fonte: Baseado em IPT, 2004) ...................................................... 184

Quadro 6 - Obra B: Vistoria 2. (Fonte: Baseado em IPT, 2004) ..................................................... 185

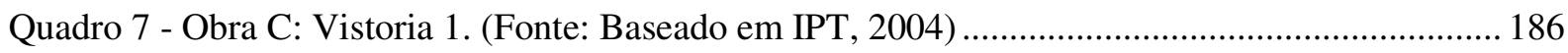

Quadro 8 - Obra C: Vistoria 2. (Fonte: Baseado em IPT, 2004) …................................................. 187

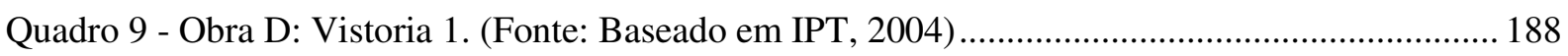

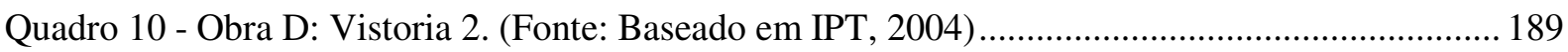

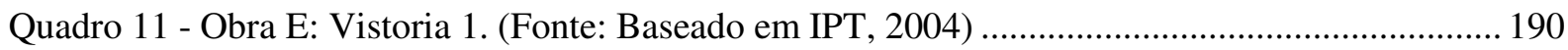

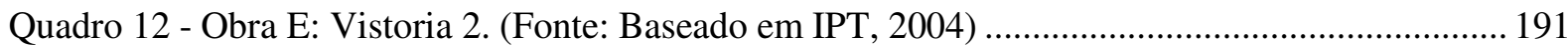




\section{LISTA DE TABELAS}

Tabela 1 - Situações relevantes para diferentes estratégias de pesquisa. (Fonte: Cosmos Corporation apud Yin, 2001)

Tabela 2 - Definição dos propósitos dos estudos e estratégias das pesquisas realizadas no presente trabalho, com base em Yin (2001)......

Tabela 3 - Interferência dos principais agentes envolvidos no processo de produção de edifício, quanto à qualidade do processo e do produto final. (Fonte: Helene; Souza, 1988)......

Tabela 4 - Os princípios da organização baseada no conhecimento. (Fonte: Adaptado de Sveiby, K.E. The new organizational wealth: managing and measuring knowledge-based Assets, BerrettKoehler Publishers, Inc., San Francisco, 1997 apud Pereira, 2003) .... 36

Tabela 5 - Tipos de referenciais tecnológicos estudados neste trabalho e as respectivas etapas contempladas do processo de produção.

Tabela 6 - Exemplos de códigos de práticas estrangeiros. (Fonte: Informações obtidas em pesquisas realizadas no Banco de Dados de Normas Técnicas do IPT, 2005).

Tabela 7 - Tipo e abrangência dos documentos técnicos do PROCONTROL. (Fonte: IPT, 1981a) .... 71

Tabela 8 - Documentos de Requisitos e Critérios Mínimos da CAIXA. (Fonte:

https://webp.caixa.gov.br/urbanizacao/caixacidade/links_menu_lat_esq.asp)

Tabela 9 - Descrição do projeto de implantação das obras estudadas (conjuntos habitacionais).

(Fonte: Baseado em IPT, 2004)

Tabela 10 - Principais características construtivas das obras estudadas (conjuntos habitacionais).

(Fonte: Baseado em IPT, 2004)

Tabela 11 - Não-atendimento aos requisitos constantes do MCOS para o serviço de alvenaria estrutural, nas obras estudadas. (Fonte: Baseado em IPT, 2004)

Tabela 12 - Ocorrência, nas obras estudadas, de não-conformidades cujos requisitos ou tolerâncias não fazem parte do conteúdo do MCOS. (Fonte: Baseado em IPT, 2004) 


\section{LISTA DE ABREVIATURAS E SIGLAS}

ABAI

$\mathrm{ABCB}$

$\mathrm{ABCP}$

ABECE

ABNT

ABRATEC

ACT

AFNOR

AGC

AIA

ANICER

ANTAC

APEOP

ASTM

BCA

$\mathrm{BCC}$

$\mathrm{BCMC}$

BID

$\mathrm{BNH}$

BOCA

BSI

$\mathrm{CABO}$

CAIXA

CBCA

CBIC

CCS

CCT

CDHU
Associação Brasileira da Argamassa Industrializada

Australian Building Codes Board

Associação Brasileira de Cimento Portland

Associação Brasileira de Engenharia e Consultoria Estrutural

Associação Brasileira de Normas Técnicas

Associação Brasileira das Empresas de Tecnologia da Construção Civil

Acordo de Cooperação Técnica Financeira

Association Française de Normalisation

Associated General Contractors of America

American Institute of Architects

Associação Nacional da Indústria Cerâmica

Associação Nacional de Tecnologia do Ambiente Construído

Associação Paulista de Empresários de Obras Públicas

American Society for Testing and Materials

Building Code of Australia

Building Codes Committee

Board for the Coordination of Model Codes

Banco Interamericano de Desenvolvimento

Banco Nacional da Habitação

Building Officials and Code Administrators

British Standards Institution

Council of American Building Officials

Caixa Econômica Federal

Centro Brasileiro da Construção em Aço

Câmara Brasileira da Indústria da Construção

Cahier des Clauses administratives Spéciales

Cahier des Clauses Techniques

Companhia de Desenvolvimento Habitacional e Urbano do Estado de São Paulo 
CEUBa

CGNorBât

CIB

CIESP

COBRACON

COE

COHAB

COMAT

CONDER

CONESC

CONSITRA

CPOS

CSC

CSI

CSTB

DASP

DBIA

DERBA

DIN

DOP

DRYWALL

DTU

EDIF

EJCDC

EPUFBA

EPUSP

EUA

FEP

FIESP

FINEP
Caderno de Encargos Único do Estado da Bahia

Commission Générale de Normalisation du Bâtiment

Conseil International du Bâtiment

Centro das Indústrias do Estado de São Paulo

Comitê Brasileiro de Construção Civil

Caderno de Orientações de Empreendimento

Companhia Metropolitana de Habitação

Comissão de Materiais, Tecnologia, Qualidade e Produtividade

Companhia de Desenvolvimento Urbano do Estado da Bahia

Serviço de Construções Escolares

Consórcio Setorial para Inovação em Tecnologia de Revestimentos de Argamassa

Companhia Paulista de Obras e Serviços

Construction Specifications Canadá

Construction Specifications Institute

Centre Scientifique et Technique du Bâtiment

Departamento Administrativo do Serviço Público

Design-Build Institute of America

Departamento de Infra-estrutura de transportes da Bahia

Deutsches Institut fur Normung

Departamento de Edifícios e Obras Públicas do Estado de São Paulo

Associação Brasileira dos Fabricantes de Chapas para Drywall

Documentos Técnicos Unificados

Departamento de Edificações da Prefeitura do Município de São Paulo

Engineers Joint Contract Documents Committee

Escola Politécnica da Universidade Federal da Bahia

Escola Politécnica da Universidade de São Paulo

Estados Unidos da América

Fundação Escola Politécnica

Federação das Indústrias do Estado de São Paulo

Financiadora de Estudos e Projetos 
FIRJAN

GIDUR

HABITARE

HIS

HLM

IAB

IBC

IBGE

ICBO

ICC

IFCI

IPT

ISO

JSA

MCOS

MCT

MDIC

MOP

MPO

MTE

NBS

NF-DTU

NHBC

NTC

PBQP

PBQP-H

PBS

PDCA

PES

PIB

PIS
Federação das Indústrias do Estado do Rio de Janeiro

Gerência de Filial de Apoio ao Desenvolvimento Urbano

Programa de Tecnologia de Habitação

Habitação de Interesse Social

Habitation à Loyer Modéré

Instituto de Arquitetos do Brasil

International Building Code

Instituto Brasileiro de Geografia e Estatística

International Conference of Building Officials

International Code Council

International Fire Code Institute

Instituto de Pesquisas Tecnológicas do Estado de São Paulo

International Standard Organization

Japanese Standards Association

Manual de Controle de Obras e Serviços

Ministério da Ciência e Tecnologia

Ministério do Desenvolvimento, Indústria e Comércio Exterior

Manual of Practice

Ministério do Planejamento e Orçamento

Manual Técnico de Engenharia

National Bureau of Standards

Normas Francesas - Documentos Técnicos Unificados

National House-Building Council

Instituto Colombiano de Normas Tecnicas y Certificación

Programa Brasileiro da Qualidade e Produtividade

Programa Brasileiro da Qualidade e Produtividade do Habitat

Singapore Productivity and Standards Board

Plan, Do, Check, Act

Procedimentos de Execução dos Serviços

Produto Interno Bruto

Procedimentos de Inspeção dos Serviços 
PPA

PRM

PROCONTROL

PRONAT

PROTECH

PROURB

PSQ

QUALIBAT

QUALIHAB

QUALIOP

RT

SA

SABS

SBCCI

SEAP

SEBRAE

SECOVI

SEMUS

SENAI

SENAI-RJ

SEPURB

SiAC

SICCT

SINAENCO

SindusCon-OESP

SindusCon-Rio

SindusCon-SP

SiQ

SIRIM
Plano Plurianual

The Project Resource Manual - CSI Manual of Practice

Programa de Controle de Qualidade das Construções Habitacionais

Programa Nacional de Tecnologia da Habitação

Programa de Difusão de Tecnologia para Construção de Habitação de Baixo Custo

Programa de Desenvolvimento Urbano

Programa Setorial da Qualidade

Qualification et Certification des Entreprises du Bâtiment

Programa da Qualidade da Construção Habitacional do Estado de SP

Programa de Qualidade das Obras Públicas da Bahia

Referência Técnica IPT

Standards Australia

South African Bureau of Standards

Southern Building Code Congress International

Secretaria de Estado da Administração e Patrimônio

Serviço Brasileiro de Apoio às Micro e Pequenas Empresas

Sindicato das Empresas de Compra, Venda, Locação e Administração de Imóveis Comerciais e Residenciais

Serviço de Engenharia e Manutenção de Unidades de Saúde

Serviço Nacional de Aprendizagem Industrial

Serviço Nacional de Aprendizagem Industrial do Estado do Rio de Janeiro

Secretaria de Políticas Urbanas

Sistema de Avaliação da Conformidade de Empresas de Serviços e Obras da Construção Civil

Secretaria da Indústria, Comércio, Ciência e Tecnologia do Estado de São Paulo

Sindicato Nacional das Empresas de Arquitetura e Engenharia Consultiva

Sindicato Intermunicipal de Araçatuba das Indústrias de Construção Civil

Sindicato da Indústria da Construção Civil no Estado do Rio de Janeiro

Sindicato da Indústria da Construção Civil do Estado de São Paulo

Sistema de Qualificação de Empresas de Serviços e Obras

Standards and Industrial Research Institute of Malaysia 
SNZ

SISG

SUCAB

UBC

UFG

UFRJ
Standards New Zealand

Sistema de Serviços Gerais

Superintendência de Construções Administrativas da Bahia

Uniform Building Code

Universidade Federal de Goiás

Universidade Federal do Rio de Janeiro 


\section{Capítulo 1}

\section{INTRODUÇão}

\subsection{Conceitos importantes para o entendimento do trabalho}

O presente trabalho, tendo como título "Referenciais tecnológicos para a construção de edifícios", induz a um prévio questionamento que precisa ser respondido de antemão: o que são os tais referenciais tecnológicos? Sendo estes definidos, passa-se então a entender, com maior facilidade, o emprego dos mesmos na construção de edifícios, que é o tema em estudo.

A definição mais recente, do ano de 2005, encontra-se no Regimento do Sistema de Avaliação da Conformidade de Empresas de Serviços e Obras da Construção Civil (SiAC) ${ }^{1}$ do Programa Brasileiro de Qualidade e Produtividade do Habitat (PBQP-H). No Capítulo II - "Das definições", Art. 3º temse:

"Referencial Tecnológico: Documento não normativo constituído por um conjunto de requisitos de caráter tecnológico e definidos pelo cliente ou por entidade de classe, que recomenda práticas ou procedimentos para projeto, produção, instalação, manutenção ou utilização de produto."

A princípio esta é a definição adotada no presente trabalho. Porém, no intuito de que este estudo contribua para o avanço do tema, tal conceito será discutido e aprimorado nos capítulos subseqüentes, sendo que no Capítulo 6 são propostas algumas modificações a essa definição.

Os referenciais tecnológicos são, portanto, documentos técnicos de referência, e podem ser utilizados, por exemplo, para as seguintes aplicações:

\footnotetext{
${ }^{1}$ Regimento válido a partir de 21 de março de 2005, data da publicação da Portaria no 118 (de 15/3/2005) no Diário Oficial da União, nº 54, Seção 1.
} 
- formalizar e disseminar o conhecimento de práticas bem sucedidas, podendo abordar etapas do processo de produção dos edifícios, desde o projeto até a execução, o controle dos serviços e do produto final, incluindo seu uso e manutenção;

- homogeneizar e padronizar alguns critérios técnicos, que tenham um caráter repetitivo, após a obtenção de consenso entre os agentes do setor da construção civil interessados;

- balizar relações contratuais, facilitando a definição dos serviços e do produto que se deseja obter, por meio de especificações, procedimentos e exigências, por exemplo para a construção de edifícios;

- suprir lacunas existentes na normalização técnica, potencializando a utilização da mesma; e

- serem utilizados, na prática das obras, como documentos técnicos que contribuem para a melhoria da qualidade do processo de produção dos edifícios e para se obter o adequado desempenho destes.

\subsection{Contextualização do tema}

Os referenciais tecnológicos estão inseridos no setor da construção civil, o qual possui efetiva relevância para o país, principalmente no âmbito econômico e social. Segundo dados do estudo realizado, em 2004, pela Federação e pelo Centro das Indústrias do Estado de São Paulo (FIESP/CIESP), a cadeia produtiva da construção civil representa cerca de $16 \%$ do Produto Interno Bruto (PIB) do país, incluindo o segmento de materiais de construção, a construção propriamente dita de edificações e obras de infra-estrutura, bem como diversos serviços de comercialização imobiliária, serviços técnicos de construção e atividades de manutenção de imóveis. O mesmo estudo evidencia a importância do setor como valiosa fonte empregatícia, principalmente como absorvedora de mão-deobra menos qualificada, gerando 15 milhões de empregos, dos quais 4 milhões são empregos diretos. O setor da construção civil é segmentado, segundo o Instituto Brasileiro de Geografia e Estatística (IBGE) em dois principais sub-setores: construção pesada e edificações, sendo este último o foco do presente trabalho.

De modo geral, face às singularidades e complexidade do processo produtivo, a construção de edifícios em geral e a construção habitacional em particular têm apresentado inúmeros problemas e deficiências. Farah (1992) expôs que o subsetor habitacional era caracterizado pela alta incidência de patologias, por elevados índices de desperdícios de diversas naturezas, pela baixa produtividade, pela reduzida mecanização e pelo uso intensivo de mão-de-obra; muitas de suas constatações e conclusões podiam, inclusive, ser generalizadas para a construção de edifícios, de um modo geral. No entanto, esse panorama vem mudando desde então, sendo possível se verificar iniciativas, algumas já 
consolidadas, como as voltadas à melhoria da qualidade e à racionalização de processos construtivos, e outras ainda citadas como "estratégias para a modernização da construção civil" pela Associação Nacional de Tecnologia do Ambiente Construído (ANTAC), em 2002, como: qualificação dos recursos humanos, integração da cadeia produtiva, gestão ambiental, bem como as inovações relacionadas à tecnologia da informação e à gestão do conhecimento. É preciso, ainda, citar o uso de inovações na construção civil relacionadas às tecnologias de produtos, processos e sistemas construtivos; a preocupação com a sustentabilidade dos edifícios não só ambiental, mas também a econômica e social; e a introdução do conceito de mentalidade enxuta na construção civil, dentre outros.

Por outro lado, também quanto à contextualização da construção civil habitacional, ainda tem-se um cenário de elevado déficit nessa área, da ordem de 7,2 milhões de habitações, segundo o ConstruBusiness (2005), realizado pela FIESP. Assim, a produção de habitações de interesse social (HIS) em larga escala tende a ser uma prioridade, o que faz com que a preocupação com a quantidade de moradias construídas possa ser um fator agravante em relação à qualidade e ao desempenho das mesmas. Além disso, o paradigma de que, para a viabilidade econômica dessas obras, deva-se ter um custo total de execução significativamente baixo, também pode influenciar negativamente a qualidade e o desempenho em questão. Acrescenta-se a isso, o fato de que a maioria dos moradores não detém condições financeiras de realizar a manutenção adequada dos edifícios implicando, muitas vezes, na necessidade de intervenção, a posteriori, por parte do agente promotor da habitação. A pesquisa relatada por Ioshimoto (1988) já demonstrava o alto índice de incidência de manifestações patológicas em conjuntos habitacionais do Estado de São Paulo e, segundo o autor, estas podem ter origem em quaisquer das etapas de produção ou utilização das edificações, relacionando-se diretamente ao nível de controle de qualidade exercido em cada uma dessas etapas e da compatibilidade entre as mesmas. Atualmente, considerando vários trabalhos realizados no âmbito de Programas da Qualidade, particularmente os realizados pelo Instituto de Pesquisas Tecnológicas (IPT), verifica-se uma sensível melhora nas condições dessas habitações, apesar de existirem ainda problemas.

Dessa forma, seria interessante que os referenciais tecnológicos fossem utilizados de forma mais rigorosa, e talvez prioritária, nas obras de HIS para auxiliar na melhoria da qualidade e do desempenho destas. Além disso, destaca-se que a elaboração e o uso de tais documentos técnicos de referência seriam facilitados perante o caráter repetitivo das técnicas construtivas adotadas em tais obras. Entretanto, é relevante salientar que os referenciais tecnológicos podem ser empregados em qualquer construção, desde que adequados a ela. Assim, neste trabalho, são estudados referenciais tecnológicos aplicados à construção de edifícios em geral, independente da sua tipologia ou padrão. 
O contexto aqui apresentado, considerando o panorama atual da situação sócio-econômica da construção civil do país, a necessidade de se introduzir melhorias na qualidade dos processos de produção dos edifícios e de se garantir o desempenho dos mesmos e, em especial das construções habitacionais, fundamenta a elaboração e disseminação de referenciais tecnológicos. Atualmente, ainda se busca o controle e a garantia da qualidade ${ }^{2}$ no processo (técnico e organizacional) envolvido em todo o empreendimento, para com isto ter confiança de que serão gerados bons produtos. Este trabalho se interessa pelas etapas iniciais do empreendimento, de concepção e execução, sendo a elaboração e o uso de referenciais tecnológicos elementos decisivos nesse processo.

\subsection{Justificativa do estudo}

A partir do contexto apresentado no item anterior, resumidamente, percebe-se que a qualidade de algumas construções em geral, e das habitacionais em particular, não se encontra de todo satisfatória, observando-se ainda, apesar de certa evolução, a deterioração algumas vezes precoce tanto das unidades habitacionais quanto das áreas comuns dos edifícios, gerando ônus aos usuários, às construtoras e, no caso das HIS, ao poder público. As razões dessas deficiências são várias e parte delas pode ser encontrada nas falhas cometidas em cada uma das etapas do processo de produção do edifício: planejamento; projeto; fabricação, controle e recebimento de materiais e componentes; execução propriamente dita e até mesmo na etapa de utilização (operação e manutenção) da obra acabada. Assim, uma das formas de se reduzir a quantidade e a intensidade das falhas em cada uma dessas etapas, a ser vista nesse trabalho, é implantando um conjunto de documentos técnicos de referência, por meio de Programas da Qualidade da construção de edifícios, por exemplo.

Portanto, a implementação de referenciais tecnológicos surge como uma alternativa para se tentar minimizar alguns problemas ainda apontados na construção de edifícios, como não-conformidades de projeto ou de execução, que possam gerar não-conformidades ou patologias, em particular na construção habitacional. É importante ressaltar que a elaboração dos referenciais tecnológicos visa, preponderantemente, à qualidade e ao desempenho da edificação e de seu entorno.

Assim, uma das abordagens deste trabalho é a seguinte: partindo-se do princípio que se tenham documentos técnicos de referência, bem definidos e de consenso entre os agentes envolvidos na cadeia produtiva do setor, que incorporem as boas práticas construtivas, como por exemplo especificações de projeto, procedimentos de execução e parâmetros de controle da qualidade do processo e do produto,

\footnotetext{
${ }^{2}$ Segundo a NBR ISO 9000:2000, o controle da qualidade é a "parte da gestão da qualidade focada no atendimento dos requisitos da qualidade", enquanto a garantia da qualidade é a "parte da gestão da qualidade focada em prover confiança de que os requisitos da qualidade serão atendidos".
} 
tem-se que a obediência a esses referenciais tecnológicos seria um dos aspectos essenciais a ser considerado durante todas as etapas do processo de produção do empreendimento, visando à obtenção de um produto final com qualidade e adequado desempenho.

Considera-se, portanto, que os referenciais tecnológicos podem abranger desde o planejamento da obra, seu projeto e execução, até o uso e manutenção do edifício e inclusive o seu pós-uso (como reforma ou demolição). Desse modo, tal documentação técnica pode estabelecer as especificações e os procedimentos a serem atendidos pelo vários agentes intervenientes na construção de edifícios: projetistas, construtores, fabricantes de materiais e componentes, órgãos responsáveis pelo planejamento, construção e manutenção, etc. Entretanto, é importante destacar que cada uma das etapas do processo de produção possui um objetivo e situa-se em contextos diferentes e, portanto, muitas vezes o tipo de documento a ser respectivamente aplicado também é diferente, conforme abordado mais detalhadamente no Capítulo 3 deste trabalho.

De modo geral, autores discutem a importância de se ter documentos técnicos de referência, normativos ou não, implementados efetivamente na construção de edifícios, sendo a documentação uma importante ferramenta para, por exemplo, a contratação de serviços. Sabbatini (1989), há mais de quinze anos, já abordava a documentação como um dos passos para a evolução tecnológica na construção de edifícios, citando a criação ou aperfeiçoamento de procedimentos operacionais e procedimentos organizacionais (planejamento, administração e controle das operações construtivas). Observa-se, porém, que alguns documentos relevantes, como os desenvolvidos no âmbito do Programa de Controle da Qualidade das Construções Habitacionais (que são inclusive apresentados no Capítulo 3), já haviam sido elaborados na época, datados do início da década de 80.

Compartilha da mesma opinião Barros (1996), expondo que "só é possível 'cobrar' aquilo que foi previamente e devidamente "combinado"”. A autora explica que a documentação funciona como elemento facilitador das relações entre empresa construtora, fornecedores e subcontratados, isso porque tanto a compra de materiais quanto a contratação de serviços podem ser feitas com base em procedimentos formalizados, deixando os agentes externos à empresa cientes de suas responsabilidades e funções. Desse modo, por meio do desenvolvimento de procedimentos operacionais pode-se estabelecer, entre outras coisas, as condições de controle dos serviços executados.

Em relação a uma aplicação mais prática da documentação técnica na construção civil, Tourinho (2001) cita em seu trabalho que quando uma construtora tem os procedimentos de cada etapa e de cada atividade de sua obra estabelecidos e documentados e os seus operários trabalham de acordo com tais procedimentos, ela tem, então, um processo produtivo passível de ser controlado sistematicamente, 
minimizando a variabilidade inerente a atividades artesanais e improvisações. Nesse contexto, o autor expõe que: "do controle do processo produtivo nasce, naturalmente, a qualidade do produto final".

Para o controle do processo de produção em sua etapa de execução, ainda quanto ao desenvolvimento e implantação de documentação técnica de referência, Meseguer (1991) faz uma analogia interessante: "os procedimentos estão para a execução dos serviços assim como as especificações estão para os materiais" e ressalta a importância desses documentos.

No decorrer desse trabalho, é possível perceber que há muito que no Brasil existem documentos com características dos referenciais tecnológicos, definidos por contratantes de projetos e obras, por exemplo. No entanto, o impacto dos mesmos nas construções a que se destinavam parece não ser muito conhecido.

Assim, o que se pode observar é que mesmo demonstrada a importância da elaboração e do uso da documentação técnica de referência na construção de edifícios, tanto de especificações de projeto e procedimentos de execução quanto de controle do processo de produção, ainda existem lacunas e obstáculos a serem superados para a sua efetiva implementação de modo extensivo.

Mesmo ciente das dificuldades a enfrentar, percebe-se que o setor da construção civil movimenta-se em prol de melhorias que consideram o resgate do desenvolvimento do tema desse trabalho. A já citada inclusão de uma definição de 'referencial tecnológico' em documento do PBHP-H é uma indicação disto, sabendo-se, ainda, que definições anteriores já constavam de documento do Programa da Qualidade da Construção Habitacional do Estado de São Paulo (QUALIHAB), desde 2001, conforme será visto no Capítulo 2 deste trabalho.

Além disso, por exemplo, a ANTAC destaca, entre outros aspectos, a necessidade de produção e disseminação de documentos técnicos de referência na construção civil brasileira em uma de suas estratégias para modernização do "Macro-complexo Construção Civil"3. Tais estratégias estão inseridas no "Plano Estratégico para Ciência, Tecnologia e Inovação na área de Tecnologia do Ambiente Construído com ênfase na Construção Habitacional”, , desenvolvido em 2002, e salientam que a construção civil brasileira ressente-se da falta de modelos de códigos de práticas (code models) e

\footnotetext{
${ }^{3}$ O Macro-complexo Construção Civil reúne a Indústria da Construção Civil e todas as cadeias produtivas que fornecem insumos para este setor: extração e beneficiamento de minerais não metálicos, insumos metálicos, madeira, cerâmica e cal, cimento, e insumos químicos (SOUZA; SILVA, 1993 apud ANTAC, 2002).

${ }^{4}$ Documento elaborado em parceria com o Ministério da Ciência e Tecnologia (MCT), a Financiadora de Estudos e Projetos (FINEP) e o PBQP-H, no âmbito do Programa Fórum de Competitividade do Ministério do Desenvolvimento, Indústria e Comércio Exterior (MDIC).
} 
guias de práticas recomendadas (best practice guides) que consolidem e disseminem procedimentos bem sucedidos de projeto e produção. Tais documentos podem ser utilizados como: "referência para a elaboração de códigos de obras, estabelecimento de contratos, produção de procedimentos de sistemas da qualidade, realização de treinamento de recursos humanos e a emissão de seguros-garantia, entre outras finalidades".

Apesar da citada "falta" desses tipos de documentos técnicos de referência no Brasil, historicamente, várias iniciativas foram realizadas nesse sentido. No Capítulo 3, deste trabalho, apresenta-se um levantamento de alguns referenciais tecnológicos nacionais, como por exemplo: cadernos de encargos, manuais técnicos, códigos de obras, relatórios de programas para controle da qualidade e guias de práticas recomendadas.

Esses tipos de documentos, que indicam as melhores práticas, segundo a ANTAC (2002), são amplamente utilizados em alguns países desenvolvidos, contribuindo para a adequada aplicação das prescrições das normas técnicas. Portanto, tem-se, aqui, mais um aspecto importante a respeito dos referenciais tecnológicos: o fato de poderem suprir algumas lacunas da normalização técnica nacional, colaborando com o uso da mesma. No Brasil, um estudo realizado por Sanchez (2003) analisou o percentual das normas do Comitê Brasileiro da Construção Civil CB-02 da Associação Brasileira de Normas Técnicas (ABNT), 375 normas, de acordo com seus respectivos tipos: normas gerais para viabilidade e contratação (6 normas); projeto e especificação (223 normas); execução de serviços (38 normas); controle tecnológico (106 normas); e manutenção (2 normas). A distribuição percentual dessa análise pode ser observada na Figura 1, destacando-se que apenas 10\% das normas tratam da execução dos serviços de um empreendimento.

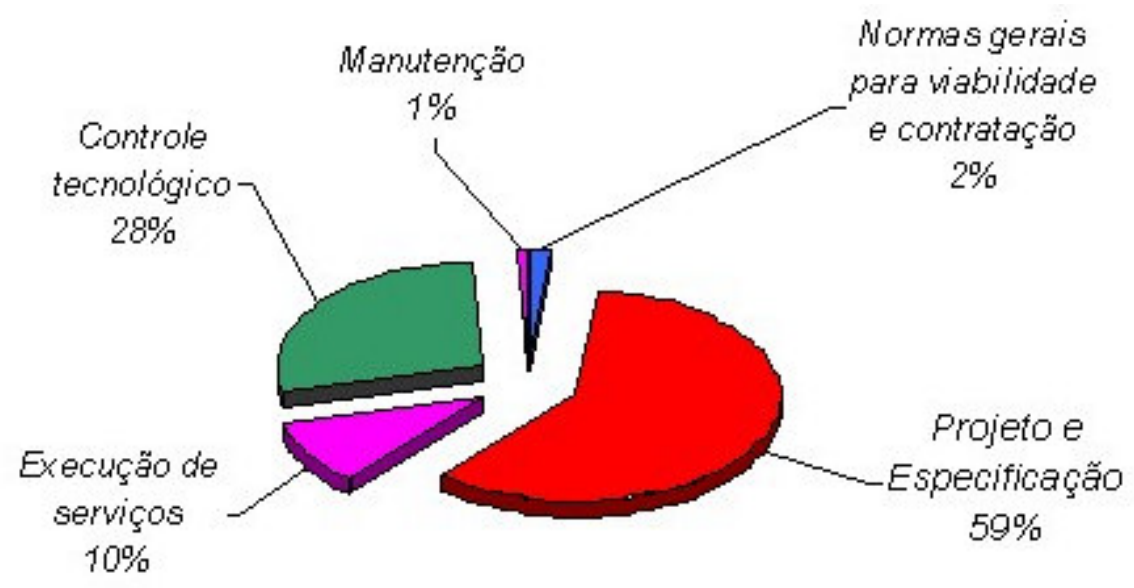

Figura 1- Distribuição percentual de normas do CB-02 por tipo. (Fonte: Sanchez, 2003) 
Ainda com relação às normas técnicas nacionais do CB-02, Sanchez (2003) realizou uma classificação de acordo com suas respectivas idades, isto é, conforme o tempo de publicação de cada norma. Foram considerados quatro intervalos de tempo: anterior ao ano 1990 (126 normas), entre 1990 e 1995 (102 normas), entre 1995 e 2000 (95 normas) e posterior ao ano 2000 (52 normas). A distribuição percentual obtida pode ser melhor visualizada na Figura 2, constatando-se que mais da metade das normas técnicas analisadas (51\%) foram publicadas há mais de 10 anos.

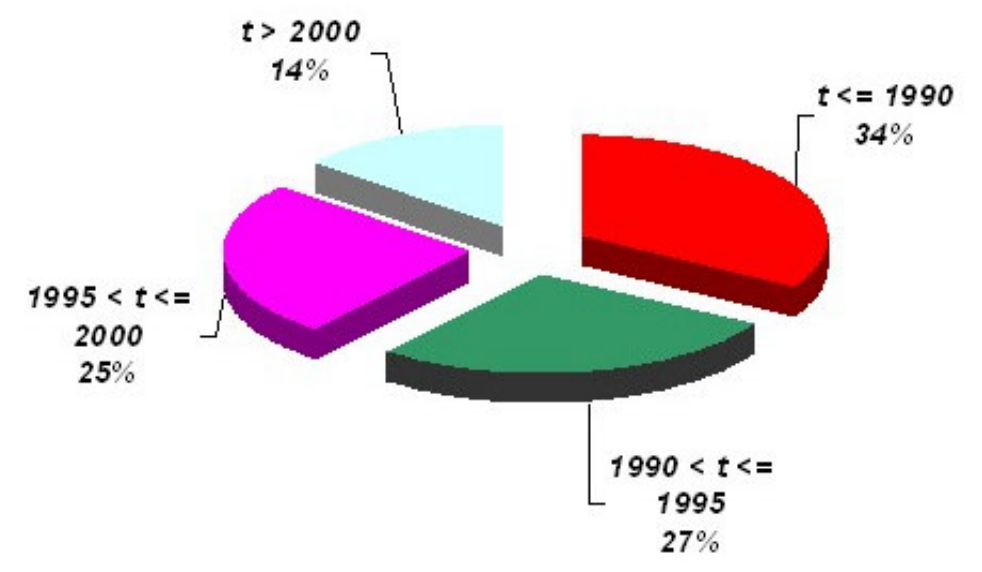

Figura 2 - Distribuição percentual de normas do CB-02 por idade. (Fonte: Sanchez, 2003) Nota: no gráfico, $t$ corresponde ao tempo de publicação da norma.

Do estudo de Sanchez (2003), observa-se que talvez fosse interessante desenvolver mais normas técnicas que dizem respeito à execução de serviços da construção civil, bem como atualizar algumas normas existentes. Porém, esse é um processo demorado e complexo, considerando-se que o Brasil possui características distintas e muito heterogêneas para cada Estado. Um primeiro passo poderia ser a criação de documentos técnicos que abrangessem as práticas locais de determinado Estado no que se refere à execução dos diferentes serviços que concorrem para a construção de um edifício e, após sua consolidação, a sua adaptação a outras regiões, de acordo com as particularidades existentes em cada local.

Além de contribuírem como embasamento complementar às normas técnicas, com referências de especificações, procedimentos de execução ou de controle que ainda não foram normalizados, ou como uma atualização às normas que se encontram obsoletas, os referenciais tecnológicos colaboram com a difusão da informação e do conhecimento. Isto é, tendo em mãos documentos que formalizem as boas práticas já consolidadas e renomadas na construção civil, os profissionais do setor adquirem maior segurança e facilidade para a realização dos respectivos serviços, uma vez que a experiência prática ou teórica bem-sucedida encontra-se registrada e pode ser aplicada. Assim, esse trabalho também se vincula à gestão da informação e do conhecimento, sendo os referenciais tecnológicos uma ferramenta para o compartilhamento e uso desses aspectos, criando e fixando padrões de referência e sistematização. 
Ressalta-se, ainda, que os referenciais tecnológicos também podem ser utilizados para complementar o ensino acadêmico, ou seja, como fonte de pesquisa para alunos de cursos de graduação ou pósgraduação dos cursos de engenharia civil ou arquitetura, ou ainda de tecnólogos ou técnicos, contribuindo para a formação de profissionais preparados para o mercado da construção civil, cientes de práticas que possam ser aplicadas no processo de produção de edifícios.

Sabe-se que, mesmo nos dias de hoje, uma considerável parte dos profissionais do setor ainda deparase com a insuficiência de informação ou pouco conhecimento a respeito de determinadas especificações técnicas, critérios de projeto, procedimentos de execução ou controle do processo de produção. Vê-se, nesse âmbito, a importância de se formalizar tais informações em documentos técnicos de referência que possam homogeneizar algumas ações e mantê-las atualizadas continuamente para colaborar com tais profissionais.

Além disso, perante algumas dificuldades encontradas para estipular exatamente o que se deseja obter como produto final da construção de edifícios com uma determinada finalidade, como a habitacional, por exemplo quanto ao nível de desempenho, bem como para se exigir que sejam realizados determinados procedimentos de execução ou de controle no processo de produção dos edifícios, os referenciais tecnológicos podem ser inseridos como base de relações contratuais, formalizando em contratos aspectos relevantes que possam ser cobrados pelos agentes promotores da habitação, por exemplo.

Percebe-se, do exposto até então, que os referenciais tecnológicos podem ser utilizados por diferentes clientes ou profissionais da construção civil, desde os responsáveis pelos projetos, suprimentos, execução ou controle das obras e os funcionários que executam os serviços até os estudantes da área, as entidades setoriais e os empreendedores e agentes promotores das habitações, que podem ser órgãos públicos ou empresas privadas. Assim, para cada um desses agentes, os respectivos documentos trazem benefícios que são notados no decorrer de cada uma das etapas do processo de produção de um edifício. Benefícios estes trazidos pela organização, compilação e apresentação racional de aspectos relevantes, para as determinadas etapas, que normalmente se encontram dispersos em vários textos de difícil consulta e assimilação.

Este trabalho, pretende resgatar discussões e ressaltar a importância dos documentos técnicos de referência no setor da construção civil no Brasil, inserindo-se o conceito do termo 'referencial tecnológico', no intuito de que mais um passo seja dado com relação a esse tema. Pretende-se despertar um maior interesse das entidades setoriais, empresas, financiadores, profissionais e pesquisadores da construção civil em elaborar e utilizar referenciais tecnológicos, uma vez que tais iniciativas podem influenciar no processo de produção e no produto final obtido. 
A apresentação, neste trabalho, de exemplos de documentação técnica de referência mostra que a preocupação com esse assunto não é recente, resgatando um pouco da história nesse campo. Entretanto, deve-se deixar claro que não se pretende esgotar o assunto, mas sim deixá-lo em pauta para início e continuidade de novas ações que colaborem com a formalização e disseminação das 'melhores práticas' aplicáveis à construção, visando à garantia da qualidade e do desempenho dos edifícios.

Acredita-se que o cenário atual encontra-se propício para absorver idéias e análises relativas ao tema desse trabalho, portanto justifica-se aqui o presente estudo, dada a exposição da importância da elaboração e do uso dos referenciais tecnológicos na construção de edifícios no Brasil e da necessidade de iniciativas a serem desenvolvidas de forma mais efetiva nessa área.

\subsection{Objetivos}

Buscando contribuir para a melhoria da qualidade e do desempenho da construção de edifícios, por meio da consolidação e disseminação do conhecimento tecnológico e gerencial relacionados às etapas do processo de produção de edifícios, tem-se como objetivo principal do presente trabalho:

- analisar, discutir e propor orientações para a elaboração e implementação de referenciais tecnológicos para a construção de edifícios no Brasil.

Assim, alguns objetivos secundários também são atingidos com esse estudo:

- apresentação e discussão de conceitos relativos aos referenciais tecnológicos, sua inserção na construção de edifícios e algumas interfaces, no caso, com o conceito de qualidade, desempenho e gestão do conhecimento;

- identificação e apresentação de alguns modelos de documentos técnicos de referência já existentes, por meio de um breve levantamento do estado-da-arte de referenciais tecnológicos na construção de edifícios, analisando-se experiências estrangeiras e nacionais;

- conhecimento, com maior profundidade, dos seguintes documentos:

- Documentos Técnicos Unificados (DTU), utilizados na França - com o objetivo de obter informações que possam ser integradas aos documentos brasileiros; e

- Manual de Controle de Obras e Serviços (MCOS), documento utilizado em obras habitacionais no Estado de São Paulo - com o intuito de analisar uma aplicação prática de um tipo de referencial tecnológico nacional. 
Como delimitação do escopo da pesquisa, em relação às etapas do processo de produção de edifícios, o foco, neste trabalho é dado aos documentos de especificação de projeto, de procedimentos de execução e de controle do processo de execução. Portanto, são priorizadas as etapas de projeto e execução, não sendo contemplados, por exemplo, documentos específicos em relação às etapas de entrega do edifício e de manutenção e uso do mesmo.

\subsection{Metodologia de Desenvolvimento do Trabalho}

Para a concretização dos objetivos propostos, o trabalho parte de um estudo teórico, apoiado nas principais bibliografias encontradas sobre o tema, e se complementa com estudos, de caráter qualitativo, envolvendo descrições e análises de documentos técnicos de referência. Por fim, tem-se uma síntese e análise global do tema estudado, embasando as discussões e algumas propostas desse estudo. Portanto, o trabalho está estruturado em três etapas, conforme pode ser visto na Figura 3.

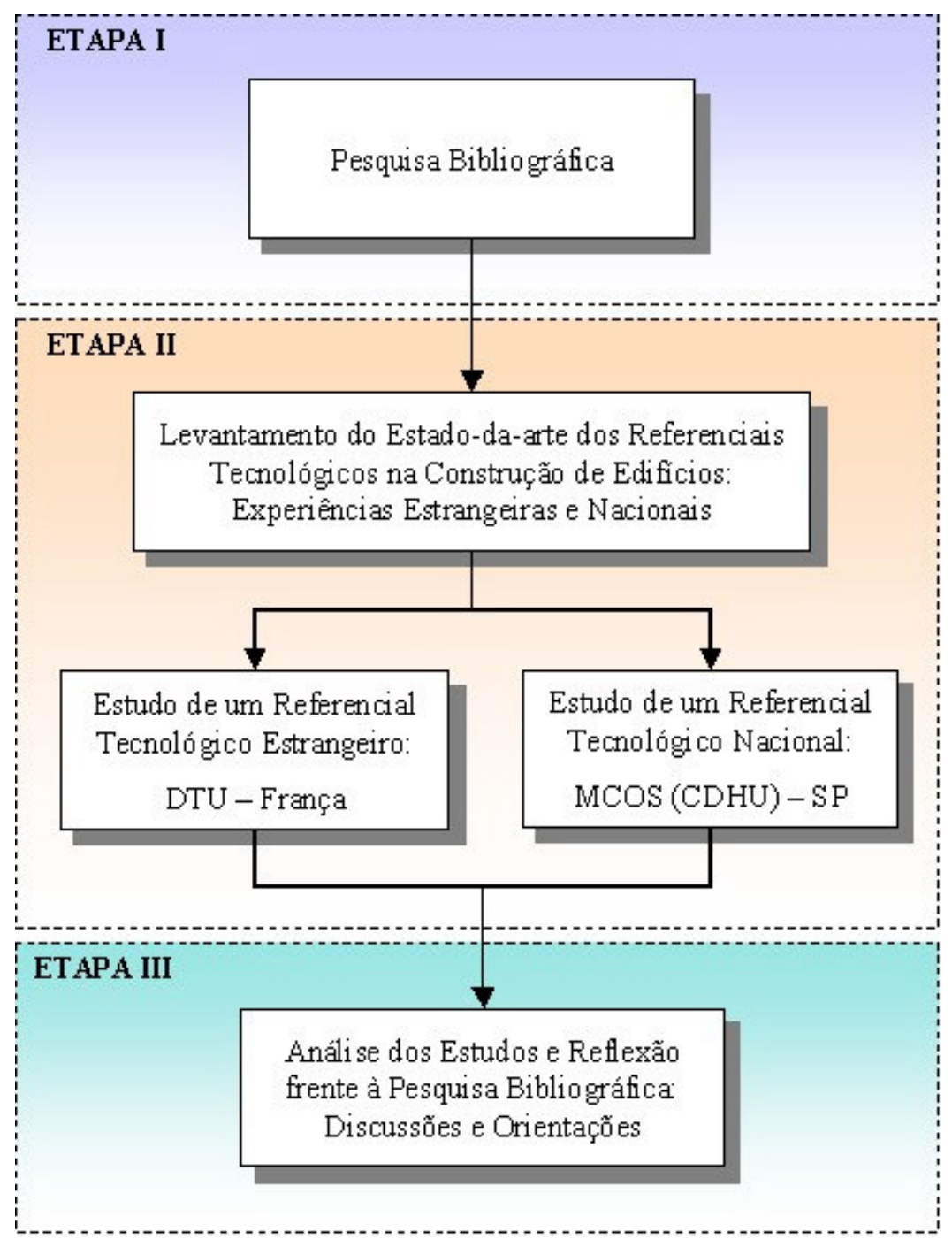

Figura 3 - Representação gráfica da metodologia do presente estudo. 
Etapa I - Pesquisa e análise de referências bibliográficas.

Este item envolve a pesquisa de informações sobre o atual contexto do setor da construção civil no Brasil, particularmente quanto aos aspectos que podem influenciar direta ou indiretamente a qualidade e o desempenho dos edifícios, bem como os aspectos relacionados à disseminação e gestão da informação e do conhecimento. A análise dessa bibliografia dá suporte à contextualização e justificativa do trabalho (Capítulo 1), constatando-se a importância e a necessidade do presente estudo.

Este item ainda contém pesquisas bibliográficas que fundamentam o Capítulo 2, a respeito do conceito de qualidade, principalmente quanto ao surgimento e a implantação de Programas da Qualidade no Brasil, os quais contêm em seus Regimentos definições do termo 'referenciais tecnológicos'. Estudase, também, o conceito de desempenho, abordando o atual desenvolvimento deste como normalização técnica na construção de edifícios. Desta análise depreende-se subsídios para identificar os fatos que culminaram na situação atual da construção no Brasil, em relação a esses conceitos, tendo como principal foco a inserção dos referenciais tecnológicos nesse cenário. Para tanto, também se pesquisa sobre a gestão do conhecimento, pelo vínculo que esta apresenta com a elaboração e difusão dos referenciais tecnológicos, incluindo-se alguns conceitos e contextualização atual.

\section{Etapa II - Desenvolvimento dos estudos sobre referenciais tecnológicos.}

Após a realização da pesquisa bibliográfica introdutória ao trabalho, são realizados os três estudos relativos aos referenciais tecnológicos utilizados na construção de edifícios, conforme apresentado, anteriormente, nos objetivos, e mostrado na Figura 3. Os três estudos são os seguintes: quanto ao estado-da-arte de referenciais tecnológicos na construção de edifícios (Capítulo 3); quanto aos Documentos Técnicos Unificados (DTU), utilizados na França (Capítulo 4); e quanto ao Manual de Controle de Obras e Serviços (MCOS), utilizado pela CDHU (Capítulo 5).

A metodologia para o desenvolvimento de tais estudos tem como base as estratégias de pesquisas definidas por Yin (2001). Segundo o autor, existem cinco tipos de estratégias de pesquisas, as quais são selecionadas de acordo com as condições de utilização de cada uma delas. Basicamente, têm-se três condições: o tipo de questão de pesquisa proposto; a extensão de controle que o pesquisador tem sobre eventos comportamentais efetivos; e o grau de enfoque em acontecimentos históricos em oposição a acontecimentos contemporâneos. Ver Tabela 1, a seguir. 
Tabela 1 - Situações relevantes para diferentes estratégias de pesquisa.

(Fonte: Cosmos Corporation apud Yin, 2001)

\begin{tabular}{l|c|c|c}
\hline $\begin{array}{c}\text { Estratégia de } \\
\text { pesquisa }\end{array}$ & $\begin{array}{c}\text { Forma da questão de } \\
\text { pesquisa }\end{array}$ & $\begin{array}{c}\text { Exige controle } \\
\text { sobre eventos } \\
\text { comportamentais? }\end{array}$ & $\begin{array}{c}\text { Focaliza } \\
\text { acontecimentos } \\
\text { contemporâneos? }\end{array}$ \\
\hline Experimento & como, por que & sim & sim \\
\hline Levantamento & quem, o que, onde, quantos & não & sim \\
\hline Análise de arquivos & quem, o que, onde, quantos & não & sim / não \\
\hline Pesquisa histórica & como, por que & não & não \\
\hline Estudo de caso & como, por que & não & sim \\
\hline
\end{tabular}

Ainda segundo Yin (2001), a visão mais apropriada dessas estratégias é pluralística, ou seja, tais estratégias não são mutuamente exclusivas, podendo-se utilizar mais de uma em um único estudo. Além disso, o autor ressalta que existem três propósitos de estudo: descritivo, exploratório ou explanatório. E, assim, cada estratégia apresentada pode ser aplicada a esses distintos propósitos.

Portanto, para o presente trabalho adotou-se os propósitos e estratégias vistos, a seguir, na Tabela 2.

Tabela 2 - Definição dos propósitos dos estudos e estratégias das pesquisas realizadas no presente trabalho, com base em Yin (2001).

\begin{tabular}{l|c|c}
\hline \multicolumn{1}{c|}{ Estudos realizados neste trabalho } & $\begin{array}{c}\text { Propósito dos } \\
\text { Estudos }\end{array}$ & $\begin{array}{c}\text { Estratégias de } \\
\text { Pesquisa }\end{array}$ \\
\hline $\begin{array}{l}\text { Estado-da-arte de referenciais tecnológicos } \\
\text { na construção de edifícios }\end{array}$ & $\begin{array}{c}\text { Descritivo } \\
\text { Exploratório }\end{array}$ & $\begin{array}{c}\text { Levantamento de dados } \\
\text { Análise de arquivos } \\
\text { Pesquisa histórica }\end{array}$ \\
\hline $\begin{array}{l}\text { Documentos Técnicos Unificados } \\
\text { (DTU), utilizados na França }\end{array}$ & $\begin{array}{c}\text { Descritivo } \\
\text { Exploratório }\end{array}$ & $\begin{array}{c}\text { Levantamento de dados } \\
\text { Análise de arquivos }\end{array}$ \\
\hline $\begin{array}{l}\text { Manual de Controle de Obras e Serviços } \\
\text { (MCOS), utilizado pela CDHU }\end{array}$ & $\begin{array}{c}\text { Descritivo } \\
\text { Explanatório }\end{array}$ & $\begin{array}{c}\text { Eevantudo de caso } \\
\text { Análise de arquivos }\end{array}$ \\
\hline
\end{tabular}

Nesta etapa foram também realizadas algumas entrevistas, que são referenciadas ao longo do texto, com profissionais que desenvolveram determinados documentos estudados, pesquisadores do IPT e um diretor de obras de uma empresa que trabalha com a Companhia de Desenvolvimento Habitacional e Urbano do Estado de São Paulo (CDHU).

O primeiro estudo, relativo ao estado-da-arte de referenciais tecnológicos na construção de edifícios, é considerado exploratório no sentido de se partir da hipótese de que já existem documentos técnicos de referência estrangeiros e nacionais e, então, buscá-los e encontrá-los utilizando-se as estratégias de pesquisa citadas na Tabela 2 para tal estudo. A seguir, confirmada a existência de tais documentos, o 
propósito é descrevê-los no presente trabalho, incluindo a verificação de suas respectivas estruturas e conteúdos como, por exemplo, se contêm especificações de projeto, procedimentos de execução, parâmetros de controle do processo, requisitos de desempenho, definição de características de materiais, exigência de ensaios, etc. A seleção dos documentos foi limitada àqueles que apresentavam um ou mais dos três aspectos seguintes: especificações do produto (projeto e desempenho do edifício, incluindo materiais e componentes), procedimentos de execução dos serviços correspondentes às etapas do processo de produção de um edifício e documentos de controle do processo de execução, conforme Tabela 5 do Capítulo 3. Segundo esse critério, todos os documentos encontrados e de possível acesso, desde que fizessem parte de um contexto contratual entre agentes da cadeia produtiva ou que visassem à disseminação do conhecimento e das boas práticas da construção de edifícios, foram apresentados nesse trabalho. Foram, porém, encontradas algumas dificuldades como a obtenção de determinados documentos estrangeiros, que não estavam disponibilizados em bibliotecas e precisariam ser comprados, e alguns documentos nacionais por serem muito antigos, ou muito recente, estando inclusive em fase de desenvolvimento.

O segundo estudo, o qual se refere aos Documentos Técnicos Unificados (DTU) utilizados na França, é descritivo no sentido de que um dos propósitos é apresentar tais documentos, ainda pouco conhecidos no Brasil. Para tanto, foram utilizados relatórios de pesquisadores brasileiros a respeito do assunto, além de documentos franceses que foram traduzidos neste trabalho. Desse modo, pretende-se, ainda, descrever a estrutura, o conteúdo e a forma de elaboração de um DTU, no intuito de que tais conhecimentos possam contribuir para o desenvolvimento de um sistema semelhante para o Brasil. Assim, o outro propósito é explorar o uso dos DTU para o contexto brasileiro, apresentando, inclusive, algumas análises já feitas por pesquisadores franceses e brasileiros; e nesse sentido, é considerado um estudo exploratório.

O terceiro estudo, o qual trata do Manual de Controle de Obras e Serviços (MCOS) utilizado pela CDHU, pode ser considerado descritivo por também se ter o propósito de apresentar este documento que, por ser de uso recente e restrito às construções habitacionais promovidas pela CDHU, em São Paulo, acredita-se que seu conhecimento não seja de todo abrangente. Além disso, o citado propósito explanatório é devido à apresentação da aplicação prática desse documento, considerada aqui como um estudo de caso, uma vez que aborda como o MCOS está sendo aplicado nas obras, por meio de vistorias técnicas, das quais a autora deste trabalho também participou. Segundo Yin (2001), o estudo de caso é a estratégia escolhida ao se examinarem acontecimentos contemporâneos, mas quando não se podem manipular comportamentos relevantes. Como fonte de evidências dos estudos de caso, podese ter, por exemplo, documentação, registros em arquivos, entrevistas e observações diretas. A partir disso, também se realiza uma análise do conteúdo do Manual. 
As informações relevantes que são particulares a cada estudo são dadas no início do respectivo capítulo referente a cada um deles. São informações como, por exemplo, o por quê de se ter escolhido o DTU e o MCOS para uma análise mais detalhada, com base em quê foram feitas tais pesquisas e o que se pretende obter como resultado.

Etapa III - Análise dos estudos, discussões e orientações.

Nesta etapa, são feitas análises, realizando-se uma reflexão com as informações obtidas nas pesquisas de referências bibliográficas (Etapa I) e por meio da compilação dos dados obtidos nos três estudos desenvolvidos (Etapa II), concluindo-se o trabalho com discussões e algumas orientações para estruturação de referenciais tecnológicos na construção brasileira de edifícios (Capítulos 6 e 7).

\subsection{Estrutura do trabalho}

Este trabalho está estruturado em sete capítulos, sendo este o primeiro, no qual tem-se a introdução, contendo alguns conceitos importantes para o entendimento do trabalho, a contextualização do tema, a justificativa do estudo, o objetivo e a metodologia utilizada para o desenvolvimento da pesquisa.

No segundo capítulo são apresentados aspectos de natureza mais conceitual, relativos à inserção dos referenciais tecnológicos na construção de edifícios. Após um breve histórico do surgimento dos Programas da Qualidade na construção civil no Brasil, são abordados os vínculos destes com o tema, incluindo as definições do termo 'referenciais tecnológicos' encontradas nos respectivos Regimentos desses programas. Apresenta-se, também, o conceito de desempenho, particularmente a atual discussão de um projeto de Norma de desempenho de edifícios habitacionais, o que incentiva a geração de referenciais tecnológicos. E, por fim, aborda-se a interface e a contribuição dos referenciais tecnológicos com a gestão do conhecimento na construção de edifícios.

O capítulo três apresenta um breve levantamento do estado-da-arte dos referenciais tecnológicos na construção de edifícios. São apresentados alguns tipos de documentos técnicos de referência e, a seguir, faz-se uma descrição de algumas experiências internacionais e nacionais. Apresenta-se alguns documentos, visando mostrar experiências já desenvolvidas quanto a esse assunto e obter referências, principalmente quanto à estrutura e ao conteúdo de cada um deles, que sirvam para auxiliar a elaboração de referenciais tecnológicos. Em relação à pesquisa de experiências estrangeiras, são apresentados os seguintes documentos: Project Resource Manual - CSI Manual of Practices, National House-Building Council Standards, Uniform Building Code, Building Code of Austrália e International Building Code. Quanto aos documentos técnicos de referência nacionais tem-se: Cadernos de Encargos elaborados, respectivamente, pelos engenheiros Paulo Costa e Milber Guedes; 
os Cadernos de Encargos do Governo do Estado do Rio de Janeiro, da Bahia e de São Paulo, bem como da Prefeitura do Município de São Paulo; as Práticas DASP e Práticas SEAP, aplicáveis a nível Federal; os Relatórios do Programa de Controle de Qualidade das Construções Habitacionais (PROCONTROL) e dos Estudos para o Controle de Qualidade dos Componentes, Elementos e do Produto Final de Conjuntos Habitacionais, ambos trabalhos realizados pelo IPT, sendo o primeiro para o extinto Banco Nacional da Habitação (BNH) e o segundo para a então Secretaria da Indústria, Comércio, Ciência e Tecnologia do Estado de São Paulo (SICCT); o Manual Técnico do então Departamento de Edifícios e Obras Públicas (DOP) da Secretaria de Obras e do Meio Ambiente do Governo do Estado de São Paulo; os Documentos de Requisitos e Critérios Mínimos a serem atendidos para solicitação de financiamento junto à Caixa Econômica Federal (CAIXA); o Manual Técnico de Engenharia da CAIXA, aplicado ao Estado de São Paulo; as Recomedações Técnicas HABITARE; e o Guia da Qualidade dos Processos Construtivos (software ainda em desenvolvimento pelo Senai-RJ, Sinduscon-RJ, Clube da Qualidade na Construção e patrocínio do Sebrae-RJ).

O quarto capítulo refere-se ao estudo dos Documentos Técnicos Unificados implementados na França. Apresenta-se o funcionamento dos mesmos, o histórico, os objetivos, as vantagens e desvantagens, a elaboração, o conteúdo e outros dados e informações relevantes para a análise sobre os DTU e o contexto brasileiro, a qual é feita no final do capítulo. Os mesmos cobrem as etapas de projeto, execução, controle e, inclusive, manutenção.

O capítulo cinco apresenta o estudo sobre o Manual de Controle de Obras e Serviços (MCOS) da CDHU. Apresentam-se algumas ações que levaram à elaboração de tal Manual, os objetivos do mesmo, seu conteúdo e estrutura, dentre outros detalhes relevantes. Realiza-se uma análise de seu conteúdo, quando da sua aplicação em algumas obras de conjuntos habitacionais do Estado de São Paulo, visando apresentar, à luz de uma experiência prática, um documento técnico de referência aplicado ao controle do processo de execução e recebimento de serviços.

O sexto capítulo apresenta uma análise da pesquisa bibliográfica realizada e dos três estudos apresentados anteriormente, resultando em discussões e orientações sobre a elaboração e o uso de referenciais tecnológicos na construção de edifícios no Brasil.

Finalmente, o capítulo sete apresenta as considerações finais a respeito deste trabalho, mostrando o atendimento aos objetivos estabelecidos e propondo alguns temas para a continuidade do estudo. Seguem, ainda, as referências bibliográficas utilizadas na pesquisa, algumas bibliografias adicionais para consulta, um Anexo ("Manual de Controle de Obras e Serviços - Desvios e Tolerâncias Admitidas: Serviço de Alvenaria Estrutural") e dois Apêndices elaborados pela autora ("Resumo das constatações apontadas nas vistorias às obras: serviço de alvenaria estrutural" e "Proposta de base para estrutura de um modelo de documento técnico de referência para a construção de edifícios”). 


\section{Capítulo 2}

\section{INSERÇÃo DE REFERENCIAIS TECNOLÓGICOS NA CONSTRUÇÃo DE EDIFÍCIOS: QUALIDADE, DESEMPENHO E GESTÃO DO CONHECIMENTO}

$\mathrm{Na}$ busca de ganhos de eficiência técnica e econômica surgem, como verdadeiros desafios para as empresas, as tentativas de melhoria da qualidade e do desempenho de seus produtos, processos ou mesmo de seus sistemas de gestão.

Os referenciais tecnológicos podem contribuir para a superação desses desafios, desde que sejam adequadamente elaborados e efetivamente utilizados na prática, no dia-a-dia das empresas.

Atualmente, a implementação de referenciais tecnológicos está inserida nos principais Programas da Qualidade da construção civil brasileira: o Programa da Qualidade da Construção Habitacional do Estado de São Paulo (QUALIHAB) e o Programa Brasileiro da Qualidade e Produtividade do Habitat (PBQP-H). Portanto, neste capítulo, apresenta-se um breve histórico do surgimento desses programas no país, visando ao entendimento da importância e necessidade dos mesmos para o setor da construção civil. Pretende-se ainda elucidar a estrutura de funcionamento desses Programas, explicitando a integração dos referenciais tecnológicos ao seu contexto e, inclusive, abordando as definições do termo 'referenciais tecnológicos' encontradas nos seus respectivos Regimentos.

Salienta-se, aqui, que o desenvolvimento de documentos técnicos de referência extrapola o conceito de gestão da qualidade, estando também vinculado à especificação do desempenho do produto que se deseja obter e à consolidação e disseminação do conhecimento do setor. Desse modo, apresentam-se, ainda neste capítulo, tais interfaces, discutindo aspectos que estão correlacionadas à elaboração dos referenciais tecnológicos.

\subsection{Programas da Qualidade para a construção civil e a integração dos referenciais tecnológicos}

Primeiramente, são apresentados alguns dados históricos para contextualizar as iniciativas que levaram ao surgimento dos atuais Programas da Qualidade para a construção civil no Brasil, incluindo a 
evolução do conceito da qualidade, das normas de gestão da qualidade e da adaptação destas para a construção civil.

Diversos autores, dentre eles Garvin (1992), Picchi (1993), CTE (1994), Souza (1997) e Mekbekian (1997), apontam que a qualidade sempre evoluiu atrelada à indústria, podendo ser organizada em quatro períodos distintos do século passado:

- Era da inspeção:

Perdurou até o final da década de 20, sendo intensamente acelerada com a Revolução Industrial e a adoção do "Gerenciamento Científico" pregado por Frederick Taylor a partir do final do século XIX, o qual separava o planejamento da execução, tornando possível um crescimento considerável na produtividade. A preocupação básica, segundo Mekbekian (1997), era a verificação da uniformidade dos produtos por meio de aparelhos de medida e mensuração, com a orientação de inspecionar a qualidade.

- Era do controle estatístico da qualidade:

Seu início é marcado pela publicação da obra Economic Control of Quality of Manufactured Product, de autoria de W. A. Shewhart, no ano de 1931. Segundo Garvin (1992), Shewhart foi o primeiro a reconhecer que a variabilidade era fato presente na indústria, podendo ser entendida por meio dos princípios da probabilidade e da estatística. Essa era perdurou entre as décadas de 30 e 40, e de acordo com Mekbekian (1997), teve a preocupação básica de controlar a uniformidade dos produtos por meio de instrumentos e técnicas estatísticas, seguindo como orientação o controle da qualidade.

- Era da garantia da qualidade:

Nessa era, segundo Garvin (1992), a qualidade passou de uma disciplina restrita e baseada na produção fabril para uma disciplina com implicações mais amplas para o gerenciamento. A prevenção de problemas continuou sendo o objetivo fundamental, mas os instrumentos da profissão se expandiram para muito além da estatística. Esse período perdurou até fins da década de 60 , sendo a qualidade vista como um problema a ser resolvido e enfrentado de maneira pró-ativa, ou seja, por meio da prevenção de defeitos. A preocupação básica era a coordenação de toda a cadeia de produção, desde o projeto até o mercado, incluindo a contribuição de todos os grupos funcionais, especialmente dos projetistas, para prevenir falhas conceituais, por meio de programas e sistemas da qualidade. 
- Era da gestão estratégica da qualidade:

Teve seu início em fins dos anos 60 e início dos anos 70, perdurando até os dias atuais. A partir da década de 70, a qualidade é encarada como uma oportunidade de concorrência, com o objetivo de atender às necessidades do mercado e do consumidor. Além do controle exercido em todas as atividades do processo de produção, destaca-se a formalização dos processos, a garantia da qualidade dos serviços, a estabilidade dos processos e rotinas, as ações sistemáticas e planejadas, a confiabilidade / certificação, a satisfação do cliente, a avaliação e melhoria contínua, o desenvolvimento de recursos humanos e as ações preventivas (CTE, 1994). A preocupação básica da 'era da gestão estratégica da qualidade', segundo Mekbekian (1997), é o impacto estratégico que o atendimento das necessidades do mercado e do consumidor proporciona à empresa. Para tanto, os métodos utilizados passam a ser: o planejamento estratégico, estabelecimento de objetivos e a mobilização da organização, com a participação de todos na empresa e uma forte liderança exercida por parte da alta gerência. Os profissionais da qualidade passam a ter responsabilidades no estabelecimento de objetivos, educação e treinamento, trabalho consultivo com outros departamentos e delineamento de programas.

Dessa forma, a abordagem da qualidade evoluiu desde inspecionar, controlar e construir a qualidade, até a questão de gerenciar a qualidade, o que marca esse quarto período. Em paralelo, observa-se que, nos últimos anos, os mercados tomaram-se extremamente competitivos, e o campo de competição dos anos 90 foi a qualidade, tendo-se um consumidor mais exigente e esclarecido. Devido a esse aumento da competição entre as empresas, e segundo Scardoelli; Silva (1994), mesmo em empresas de construção civil, estas se voltaram para o processo de produção, procurando otimizar as atividades produtivas como forma de reduzir custos, aumentar a motivação da mão-de-obra, melhorar a qualidade do produto final e melhor atender aos clientes.

Tendo em vista o panorama de evolução do conceito da qualidade e a criação da International Organization for Standardization (ISO) $)^{5}$, observou-se a realização de algumas iniciativas para a indústria uniformizar os seus conceitos, padronizar modelos para garantia da qualidade e fornecer diretrizes para implantação da gestão da qualidade nas organizações. Uma iniciativa foi o surgimento das normas de sistemas da qualidade, as quais também evoluíram ao longo do tempo.

\footnotetext{
${ }^{5}$ A ISO foi criada em 1947, como uma organização não governamental, com representantes de 25 países que se reuniram com o objetivo de instituir uma organização que tem por meta facilitar a coordenação internacional e unificar normas da indústria.
} 
Em 1987, foi lançada a série de normas ISO 9000 - Normas de Garantia da Qualidade, estabelecendo diretrizes gerais para a implementação de políticas da qualidade nas empresas. Em 1994 chega ao Brasil a versão da série ISO 9000, já revisada, onde foi adotada pela ABNT a mesma numeração da série ISO 9000, porém com a denominação NBR ISO 9000. A série era composta pelas seguintes normas:

- $\quad$ NBR ISO 9001 - Requisitos de gestão desde o projeto até a assistência técnica;

- NBR ISO 9002 - Requisitos para a gestão da produção e suprimentos;

- NBR ISO 9003 - Requisitos para a gestão dos controles e ensaios finais do processo;

- $\quad$ NBR ISO 9004 - Diretrizes para implementação do sistema de qualidade.

A Norma NBR ISO 9000 estabelecia diretrizes gerais para a implementação de políticas da qualidade nas empresas, além de orientações para a seleção do modelo de garantia da qualidade a ser observado nos acordos comerciais.

As normas da série ISO 9000 versão 1994 eram de difícil interpretação, focadas no sistema da organização e exigiam uma complexa documentação do sistema, entre outras particularidades. Estas deficiências causaram o detrimento dos objetivos reais da norma e, freqüentemente, a obtenção do certificado foi mais importante que a melhoria da qualidade e do sistema de gestão.

A necessidade da atualização das normas ISO 9000, em decorrência das exigências do mercado, culminou na sua versão 2000. A versão 2000 aboliu as normas NBR ISO 9002 e 9003, e incorporou os requisitos referentes a elas em uma norma única, a NBR ISO 9001:2000.

A série ISO 9000:2000, em relação à versão anterior, apresenta o seu foco no cliente, um enfoque no processo e maior ênfase na avaliação e melhoria da empresa e do próprio sistema de gestão. Atualmente, as normas da série ISO 9000 continuam sendo um guia para a implantação da qualidade em qualquer setor produtivo de bens ou serviços, servindo para orientar as relações comerciais entre produtores e consumidores.

Entretanto, quanto ao setor da construção de edifícios no Brasil, em virtude das exigências dos clientes (usuários), da necessidade de modernização dos procedimentos de controle da qualidade e da própria implementação dos sistemas de gestão da qualidade das empresas do setor, os agentes da cadeia produtiva perceberam que havia uma lacuna tecnológica e gerencial na cadeia produtiva. Esta lacuna, que dificultava a implantação da norma internacional no setor, acabou orientando-o para que buscasse um conjunto de requisitos e diretrizes que contemplassem as características específicas e as devidas particularidades do setor da construção civil, as quais não fazem parte, explicitamente, do escopo das normas da série NBR ISO 9000, de características genéricas. 
Essas características específicas, que diferenciam a indústria da construção civil de todas as demais, já foram abordadas por diversos autores. Dentre eles, Farah (1992) e Picchi (1993) citaram na época as principais particularidades encontradas: o caráter nômade, ou seja, o produto (obra) fica e a indústria se muda; os produtos, em geral, são únicos, havendo pouca ou nenhuma repetição; o ciclo de produção é longo, normalmente sendo medido em anos; a mão-de-obra ainda tem baixa qualificação; a indústria é tradicional, muitas vezes não incorporando inovações; existem especificações complexas, confusas e conflitantes; há dificuldade em se cumprir orçamentos e prazos; o ambiente de trabalho muitas vezes está sujeito a riscos de saúde e segurança dos operários; o valor unitário do produto final é alto; o produto tem longa vida útil; etc.

Considerando tais constatações, nos anos 90, foram implementadas algumas ações que visaram, entre outros fins, adaptar os requisitos genéricos normalizados à realidade das exigências específicas desse setor no Brasil, por meio de Programas da Qualidade com enfoque na construção de edifícios.

Além disso, no processo de produção dos edifícios existem diversos intervenientes, ou seja, agentes envolvidos que interferem na qualidade do processo e do produto final (no caso, o edifício) conforme visto na Tabela 3 na página a seguir, podendo ainda interferir no desempenho do edifício. Portanto, todos esses atores devem ser considerados quando da elaboração de um Programa da Qualidade voltado à construção.

Assim, os 'primeiros passos' para a elaboração dos Programas da Qualidade na construção no Brasil originaram-se no contexto apresentado, ou seja, de evolução do conceito da qualidade, da necessidade de adequação das normas NBR ISO 9000 às particularidades da indústria da construção civil e da constatação da necessidade de melhorias na qualidade dos edifícios (principalmente as habitações de interesse social). Portanto, de uma evolução natural de interesses do setor da construção e, com base nas experiências brasileiras do passado, principalmente as induzidas pelo $\mathrm{BNH}^{6}$, além de experiências estrangeiras, em particular da França, surgiram, no início dos anos 90, Programas da Qualidade específicos para a construção civil brasileira.

\footnotetext{
${ }^{6}$ O BNH foi criado em 1964 para realizar operações de crédito e gerir o Fundo de Garantia do Tempo de Serviço (FGTS), por intermédio de bancos privados ou públicos e de agentes promotores, como as Companhias Habitacionais e as Companhias de Água e Esgoto. O BNH foi extinto, por decreto presidencial, em 1986 e as suas funções passaram a ser assumidas, sobretudo, pela Caixa Econômica Federal.
} 
Tabela 3 - Interferência dos principais agentes envolvidos no processo de produção de edifício, quanto à qualidade do processo e do produto final. (Fonte: Helene; Souza, 1988)

\begin{tabular}{|c|c|c|}
\hline Interveniente & Papel no Processo & Interferência na Qualidade \\
\hline Agente Financeiro & $\begin{array}{l}\text { Fornece recursos financeiros para } \\
\text { viabilizar o empreendimento }\end{array}$ & $\begin{array}{l}\text { Define os níveis de desempenho a } \\
\text { atender }\end{array}$ \\
\hline Promotor & $\begin{array}{l}\text { Toma a decisão de construir e faz o } \\
\text { planejamento do empreendimento }\end{array}$ & $\begin{array}{l}\text { Define os níveis de desempenho } \\
\text { desejados }\end{array}$ \\
\hline Projetista & Projeta, especifica e calcula & $\begin{array}{l}\text { Define o desempenho potencial e as } \\
\text { qualidades específicas }\end{array}$ \\
\hline Fabricante & $\begin{array}{l}\text { Fabrica materiais, componentes e } \\
\text { equipamentos }\end{array}$ & $\begin{array}{l}\text { Responde pela qualidade dos materiais, } \\
\text { componentes e equipamentos }\end{array}$ \\
\hline $\begin{array}{l}\text { Laboratórios de } \\
\text { Ensaio }\end{array}$ & $\begin{array}{l}\text { Ensaia materiais, componentes, } \\
\text { elementos, sistemas e equipamentos }\end{array}$ & $\begin{array}{l}\text { Comprova a conformidade } \\
\text { Avalia o desempenho }\end{array}$ \\
\hline Construtor & Executa as obras & $\begin{array}{l}\text { Responde pela qualidade dos serviços e } \\
\text { do produto final }\end{array}$ \\
\hline $\begin{array}{l}\text { Empresas de } \\
\text { Organização e } \\
\text { Controle }\end{array}$ & $\begin{array}{l}\text { Gerencia partes do empreendimento e } \\
\text { projeta e executa planos de controle }\end{array}$ & Controla a qualidade \\
\hline $\begin{array}{l}\text { Associações } \\
\text { Normativas }\end{array}$ & $\begin{array}{l}\text { Produzem normas preferencialmente por } \\
\text { consenso entre consumidores e } \\
\text { produtores }\end{array}$ & $\begin{array}{l}\text { Define a qualidade de forma geral } \\
\text { Certifica a conformidade }\end{array}$ \\
\hline Proprietário & $\begin{array}{l}\text { Toma a decisão de construir e contrata } \\
\text { os serviços } \\
\text { Promove a manutenção do produto final }\end{array}$ & $\begin{array}{l}\text { Influi na qualidade através da forma de } \\
\text { contratação } \\
\text { Mantém o desempenho ao longo do } \\
\text { tempo }\end{array}$ \\
\hline $\begin{array}{l}\text { Universidades e } \\
\text { Institutos de } \\
\text { Pesquisa }\end{array}$ & $\begin{array}{l}\text { Forma profissionais } \\
\text { Desenvolve novos conhecimentos e } \\
\text { novas tecnologias } \\
\text { Difunde informações tecnológicas }\end{array}$ & $\begin{array}{l}\text { Desenvolve metodologias de controle e } \\
\text { fornece assistência tecnológica ao } \\
\text { processo de produção } \\
\text { Gera documentação técnica de } \\
\text { referência }\end{array}$ \\
\hline Estado & Estabelece a legislação pertinente & $\begin{array}{l}\text { Define a qualidade de forma geral } \\
\text { Aprova projetos } \\
\text { Pune a falta de qualidade }\end{array}$ \\
\hline $\begin{array}{l}\text { Associações } \\
\text { Profissionais }\end{array}$ & $\begin{array}{l}\text { Ordena o exercício e a responsabilidade } \\
\text { dos profissionais }\end{array}$ & $\begin{array}{l}\text { Identifica os responsáveis pela qualidade } \\
\text { das partes }\end{array}$ \\
\hline Usuário & Desfruta e opera o produto final & $\begin{array}{l}\text { Explicita necessidades } \\
\text { Sofre as conseqüências da má qualidade }\end{array}$ \\
\hline
\end{tabular}

Nota: Além dos intervenientes observados na Tabela 3, podem ser citados os Organismos de Certificação Credenciados, responsáveis por avaliar produtos, processos e sistemas segundo referenciais pré-definidos e cuja interferência na qualidade dá-se por meio da certificação da conformidade.

Em relação aos programas de gestão e de certificação da qualidade, Melhado (2001) cita que a implementação destes tem como base "a padronização, o controle e a melhoria dos processos, através da formalização e padronização dos procedimentos de execução e da monitorização e avaliação desses procedimentos". Com isso, segundo o autor, as empresas buscam ampliar o domínio técnico e a previsibilidade sobre os insumos utilizados e sobre os processos de trabalho. O objetivo é obter maior 

conhecimento

controle sobre a qualidade dos produtos e serviços gerados e facilitar a introdução consistente de novas técnicas e tecnologias de produção em direção à melhoria contínua.

Além disso, conforme observado por Vivancos (2001), a tendência de desenvolvimento de parâmetros técnicos, como códigos de prática e normas técnicas, tende a aumentar em função do aumento da demanda por qualidade e da implementação desses Programas da Qualidade no Brasil, como o QUALIHAB e o PBQP-H, visando garantir maior regulamentação e padronização de critérios tecnológicos dos processos de produção no setor de edificações. A seguir, esses dois Programas são vistos mais detalhadamente.

\subsubsection{Programa QUALIHAB}

Segundo Motta (1995), a Secretaria da Habitação do Estado de São Paulo e a CDHU começaram a se dar conta de que, no início da década de 90, uma série de problemas construtivos observados poderiam ter sido evitados se existisse uma verdadeira política da qualidade nos empreendimentos habitacionais financiados pelo Estado.

Nesse sentido, e considerando-se as razões já apontadas anteriormente, foram desenvolvidas diversas ações que culminaram com o destaque do pioneiro Programa QUALIHAB, implementado e coordenado pelo maior agente promotor de habitações de interesse social no país, a CDHU, juntamente com o apoio da Escola Politécnica da Universidade de São Paulo (EPUSP) e do Instituto de Pesquisas Tecnológicas do Estado de São Paulo (IPT).

O QUALIHAB, em suas ações voltadas às empresas de serviços e obras, possui diversas semelhanças com o que preconiza a série de normas de sistemas de qualidade, tanto quanto aos objetivos, quanto aos meios (requisitos a serem observados), pois, segundo Cardoso et al (1999) o Programa parte da adaptação da norma NBR ISO 9002:1994 às características do setor de edificações, incorporando o conceito de "níveis de certificação".

No que se refere às ações voltadas para as empresas construtoras, o QUALIHAB foi inspirado no modelo francês do Programa QUALIBAT (Qualification et Certification des Entreprises du Bâtiment), existente desde 1992, que envolve um sistema de certificação das empresas construtoras e de empresas que executam serviços especializados nos canteiros de obra, complementar a outro sistema de qualificação de empresas, existente desde o final da Segunda Grande Guerra. Tem como objetivo fornecer aos clientes informações sobre as empresas que atuam no setor e atestar a implementação de um Sistema de Garantia da Qualidade. 
Segundo Mitidieri Filho (2005) ${ }^{7}$, a primeira reunião para discussão do QUALIHAB foi realizada em dezembro de 1993 no IPT, com a participação da CDHU, EPUSP, Sindicato da Indústria da Construção Civil do Estado de São Paulo (SindusCon-SP), entre outros agentes da cadeia produtiva. A primeira iniciativa de implantar legalmente o Programa foi em 1994, sendo o QUALIHAB formalmente instituído em 1996, por meio do Decreto № 41.337, do Governo do Estado de São Paulo.

O QUALIHAB foi planejado segundo princípios modernos de 'parceria' e 'evolução gradativa da qualidade', reunindo praticamente toda a cadeia produtiva da construção civil e servindo, inclusive, de paradigma para outros programas da qualidade que se desenvolveram pelo país.

Consolidado ao longo de dez anos de implantação, o QUALIHAB constitui experiência prática para agentes promotores da habitação, empresas construtoras, fabricantes de materiais e o meio técnico em geral, visando principalmente à melhoria da qualidade da habitação de interesse social entregue pela CDHU à população do Estado de São Paulo.

O Programa está estruturado segundo uma Coordenação Geral e uma Secretaria Executiva, que coordenam três comitês: o Comitê de Projetos e Obras que congrega as entidades representativas das empresas de construção e projetos, dentre outras; o Comitê de Materiais, Componentes e Sistemas Construtivos que congrega as entidades dos produtores de insumos para as obras e, de sistemas construtivos; e, o Comitê Interno, encarregado de implantar um sistema de Gestão da Qualidade na CDHU.

Utilizando o seu poder de compra junto ao mercado da construção civil, a CDHU, por meio do Programa QUALIHAB, vem induzindo os segmentos do meio produtivo a estabelecerem, com a empresa, Acordos Setoriais que visam ao desenvolvimento de programas da qualidade para cada um dos setores representados, ditos Programas Setoriais da Qualidade (PSQ). Deste modo, está, por exemplo, exigindo em seus editais de licitações que as empresas construtoras obedeçam aos programas setoriais e às normas técnicas e comprovem sua qualificação, como condição para serem habilitadas a executarem obras para a Companhia.

Cada entidade participante, ao firmar o Acordo Setorial com a CDHU e o QUALIHAB, assume o compromisso de desenvolver o PSQ junto às empresas que representa. No caso do Comitê de Projetos e Obras, o objetivo do PSQ foi implementar um sistema único da qualidade, o qual contempla a revisão e complementação de normas ABNT referente ao setor em questão, a elaboração de programas de treinamento e o incentivo à certificação de sistemas.

\footnotetext{
${ }^{7}$ Em entrevista concedida no dia 16 de maio de 2005 a esta autora.
} 
Portanto, a diretriz básica do QUALIHAB para a elaboração desses Programas Setoriais da Qualidade baseia-se num tripé, composto por ações de desenvolvimento ligadas: à implementação de sistemas da qualidade; ao desenvolvimento da normalização técnica e documentos técnicos de referência; e ao treinamento de mão-de-obra.

E é aqui que se inserem os referenciais tecnológicos, integrando-se a uma das bases do tripé: a relacionada ao desenvolvimento de normalização técnica ou documentos técnicos de referência. É importante ressaltar que apesar da inserção dos referenciais tecnológicos ser apresentada, prioritariamente, nesta base, existe uma interação com as demais. Isso porque tais documentos devem ser considerados incorporados pelas empresas que possuem um sistema de gestão da qualidade e, ainda como documentação técnica de referência, podem, futuramente, influenciar ações de treinamento e qualificação da mão-de-obra para o setor. Desse modo, um esquema ilustrativo da inserção e das interações dos referenciais tecnológicos nos Programas da Qualidade pode ser visto na Figura 4, a seguir.

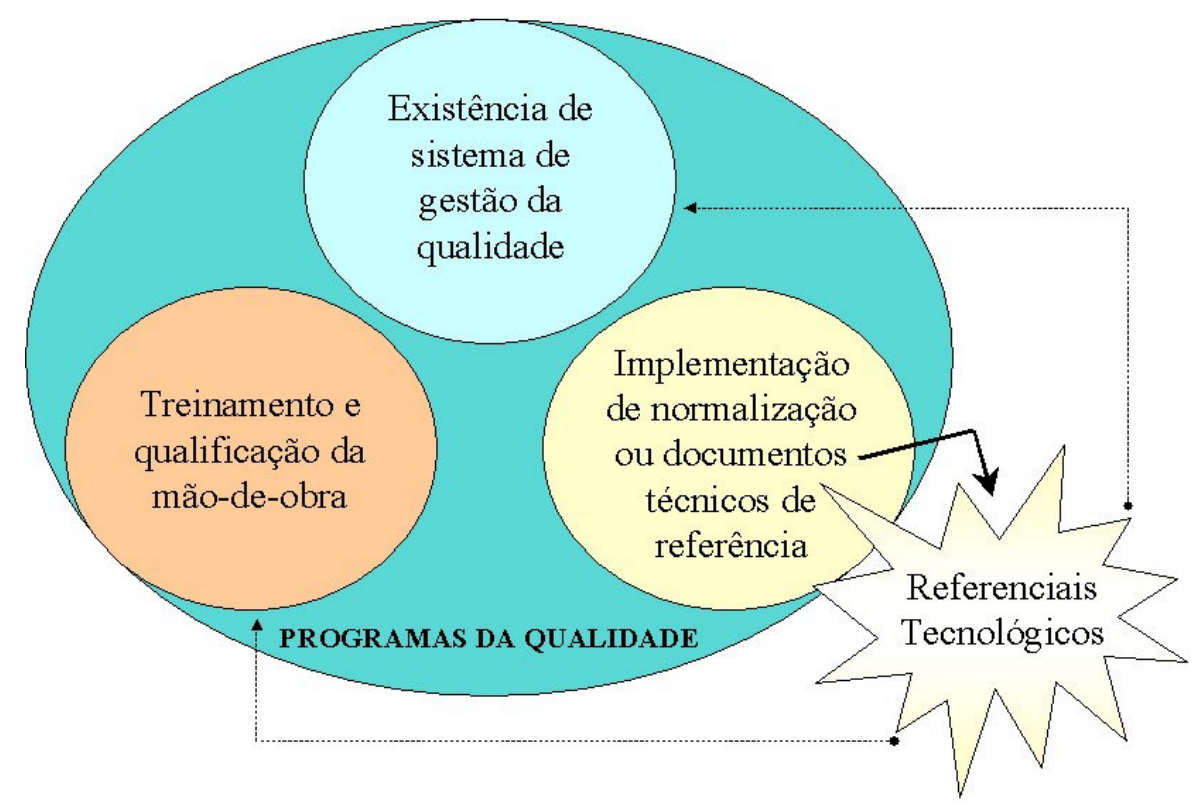

Figura 4 - Inserção dos referenciais tecnológicos nos Programas da Qualidade.

Ressalta-se, entretanto, que apesar de já existir a preocupação com a implementação de documentos técnicos de referência no Programa, o termo em si 'ReferenciaisTecnológicos' ainda não era citado nem definido no Regimento de Qualificação de Sistemas do QUALIHAB, pelo menos até a sua versão de junho de 2000.

Somente a partir da versão de julho de 2001 é que foi encontrada a definição de Referenciais Tecnológicos para materiais, componentes e equipamentos, bem como para serviços de execução, as quais são a seguir descritas: 
Capítulo 2 - Inserção de referenciais tecnológicos na construção de edifícios: qualidade, desempenho e gestão do conhecimento

"Referenciais Tecnológicos referentes a materiais, componentes e equipamentos de obras: São constituídos por um conjunto de requisitos definidos pela CDHU que permitem a homogeneidade das ações para inspeção e recebimento dos mesmos, contendo, conforme o caso, as tolerâncias permitidas".

"Referenciais Tecnológicos referentes a serviços de execução: São constituidos por um conjunto de requisitos definidos pela CDHU que permitem a homogeneidade das ações para o seu controle de produção e de recebimento, contendo, conforme o caso, as tolerâncias permitidas".

Em maio de 2003 foi publicada uma versão revisada do Regimento de Qualificação de Sistemas do QUALIHAB, válida até os dias de hoje, a qual suprimiu a definição de Referenciais Tecnológicos para materiais, componentes e equipamentos, referentes às especificações, e manteve a definição anterior para os Referenciais Tecnológicos referentes a serviços de execução. Estes últimos, porém, passaram a ser também denominados como "Manual de Controle de Obras e Serviços - Lista de Verificação e Desvios Admitidos". Portanto, o Capítulo III - "Das definições", em seu artigo 9, apresenta a seguinte definição:

"Referenciais Tecnológicos ou Manual de Controle de Obras e Serviços - Lista de Verificação e Desvios Admitidos, referentes a serviços de execução: São constituídos por um conjunto de requisitos definidos pela CDHU que permitem a homogeneidade das ações para o seu controle de produção e de recebimento, contendo, conforme o caso, as tolerâncias permitidas".

Esse referencial tecnológico de serviços, ou seja, o Manual de Controle de Obras e Serviços será estudado, mais detalhadamente, no Capítulo 5 deste trabalho.

Não se deve esquecer, no entanto, que o Programa QUALIHAB abrange somente o Estado de São Paulo. A importância de se instituir Programas da Qualidade voltados à construção também é vista a nível nacional, verificando-se a existência de ações para o desenvolvimento de programas que atendam a esse setor no Brasil, conforme visto a seguir.

\subsubsection{Programa PBQP-H}

Em meados dos anos oitenta, de acordo com Cardoso et al (2001), o Estado começou a desenvolver ações de fomento ao desenvolvimento tecnológico na área da produção habitacional, por meio de programas tais como o Programa de Desenvolvimento Urbano (PROURB) e o Programa de 
Tecnologia de Habitação (HABITARE), da Financiadora de Estudos e Projetos (FINEP) do Ministério de Ciência e Tecnologia (MCT). Já no início dos anos noventa, surgiram como complemento o Programa Nacional de Tecnologia da Habitação (PRONAT), em 1991, do então Ministério da Ação Social e o Programa de Difusão de Tecnologia para Construção de Habitação de Baixo Custo (PROTECH), em 1993, do então Ministério do Bem Estar Social.

O Programa Brasileiro de Qualidade e Produtividade (PBQP) foi criado em 1991, com a finalidade de difundir os novos conceitos de qualidade, gestão e organização da produção. Reformulado, a partir de 1996, para ganhar mais agilidade e abrangência setorial, o Programa vem procurando descentralizar suas ações e ampliar o número de parcerias, sobretudo com o setor privado.

A partir do PBQP, surgiu o Programa Brasileiro da Qualidade e Produtividade na Construção Habitacional (PBQP-H), o qual foi instituído em 18 de dezembro de 1998 com a assinatura da Portaria n. 134, do então Ministério do Planejamento e Orçamento.

No ano 2000 foi estabelecida a necessidade de uma ampliação do escopo do Programa, que passou a integrar o Plano Plurianual (PPA) e a partir de então englobou também as áreas de Saneamento e Infra-estrutura Urbana. Assim, o "H" do Programa passou de Habitação para Habitat ${ }^{8}$, conceito mais amplo e que reflete melhor sua nova área de atuação.

O PBQP-H é um programa de adesão voluntária que se propõe a organizar o setor da construção civil em torno de duas questões principais: a melhoria da qualidade do habitat e a modernização produtiva. Este Programa conta atualmente com onze Projetos ${ }^{9}$ :

- Projeto 01- Estruturação e Gestão do PBQP-Habitat;

- Projeto 02- Sistema Nacional de Aprovações Técnicas;

- Projeto 04- Sistema de Qualificação de Empresas de Serviços e Obras - SiQ;

- Projeto 05- Qualidade de Materiais e Componentes;

- Projeto 06- Sistema Nacional de Comunicação e Troca de Informações;

- Projeto 07- Formação e Requalificação dos Profissionais da Construção Civil;

- Projeto 08- Qualidade de Laboratórios;

\footnotetext{
${ }^{8}$ Entende-se aqui o termo "Habitat" segundo a definição do Ministério do Desenvolvimento, Indústria e Comércio Exterior (MDIC): "unidade habitacional e o seu entorno, serviços essenciais de abastecimento de água, coleta e tratamento de esgotos, coleta de resíduos sólidos e sua destinação final, drenagem, distribuição de energia elétrica e gás, transportes coletivos, além de outros serviços que garantem a qualidade de vida das comunidades urbanas: abastecimento, segurança pública, educação, saúde, etc.” Informações disponíveis em: $<$ http://www.mdic.gov.br>. Acesso em: 15/7/2005.

${ }^{9}$ Informações disponíveis em: <http://www.cidades.gov.br/pbqp-h/projetos_geral.htm>. O Projeto 03 não está explícito nesse site. Nota-se que o Projeto 04, hoje, deveria se chamar Sistema da Avaliação da Conformidade de Empresas de Serviços e Obras (SiAC), conforme será visto mais adiante. Acesso em: 25/2/2006.
} 
- Projeto 09- Aperfeiçoamento da Normalização Técnica para a Habitação;

- Projeto 10- Assistência Técnica à Autogestão;

- Projeto 11- Cooperação Técnica Internacional;

- Projeto 12- Cooperação Técnica Internacional - Brasil e Mercosul.

Cada um dos Projetos citados corresponde a um conjunto de ações destinado a solucionar um problema específico na área da qualidade e que incorporaram, para sua elaboração, o diagnóstico feito em 1990 pelo PBQP, que identificou os "gargalos" existentes no setor da construção civil, com o objetivo de contribuir diretamente para o desenvolvimento do Programa.

O Projeto 09, intitulado “Aperfeiçoamento da Normalização Técnica para Habitação”, é de particular interesse para o presente estudo, pois se relaciona aos referenciais tecnológicos. Seus principais objetivos são: aumentar a produção de normas técnicas, a participação na normalização e a utilização das normas técnicas na cadeia produtiva. Tal projeto busca aumentar o envolvimento do meio técnico e a abrangência, eficiência e eficácia do sistema de normalização desenvolvendo ações específicas em conjunto com a ABNT e os diversos Comitês Brasileiros e as diversas entidades representativas da sociedade, incluindo as instituições de ensino e pesquisa superior, órgãos governamentais. Estas ações vêm sendo desenvolvidas a partir de um diagnóstico da situação de normalização, incluindo pesquisa com envolvidos nas diferentes fases da cadeia de normalização, acompanhado de busca de referências internacionais (benchmark) em países com maior sucesso na utilização de normas técnicas.

Também o Projeto 04, sob o título de "Sistema de Qualificação de Empresas de Serviços e Obras (SiQ)", apresenta interesse na medida em que foi dele que resultou a formulação do sistema que leva à certificação dos Sistemas de Gestão da Qualidade das empresas construtoras, o Sistema de Avaliação da Conformidade de Empresas de Serviços e Obras (SiAC). Este exige que as construtoras implementem procedimentos de execução e de inspeção para os serviços presentes nas obras ditos 'controlados', o que também se correlaciona ao desenvolvimento e uso de referenciais tecnológicos.

No âmbito desse Projeto é que se encontraram as definições do termo 'referenciais tecnológicos', contempladas pelo PBQP-H. A versão do Regimento do SiQ, publicada em dezembro de 2002, definia Referenciais Tecnológicos relativos tanto a materiais e componentes, quanto a serviços de execução. $\mathrm{O}$ Capítulo II do SiQ, intitulado "Das definições”, apresentava o seguinte: 
Capítulo 2 - Inserção de referenciais tecnológicos na construção de edifícios: qualidade, desempenho e gestão do conhecimento

"Referenciais Tecnológicos referentes a materiais e componentes: São constituídos por um conjunto de requisitos definidos pelo cliente ${ }^{10}$, por entidade de classe ou ainda por entidade de normalização que permitem a homogeneidade das ações para inspeção e recebimento de um dado material ou componente, contendo, conforme o caso, as tolerâncias permitidas".

"Referenciais Tecnológicos referentes a serviços de execução: São constituídos por um conjunto de requisitos definidos pelo cliente, por entidade de classe ou ainda por entidade de normalização que permitem a homogeneidade das ações para o controle de produção e de recebimento de um dado serviço de execução de obra, contendo, conforme o caso, as tolerâncias permitidas".

Nota-se que estas definições são bem similares às primeiras definições encontradas no Regimento do QUALIHAB, apresentadas no item anterior. A diferença está na entidade que define os referenciais tecnológicos, sendo que o QUALIHAB limita-se à CDHU enquanto o PBQP-H expande essa responsabilidade para a empresa contratante, entidades de classe ou de normalização.

Em março de 2005, entrou em vigor o Regimento do SiAC (antigo SiQ). No Capítulo II - "Das definições", Art. $3^{\circ}$, tem-se a seguinte definição, já citada na introdução deste trabalho:

"Referencial Tecnológico: Documento não normativo constituído por um conjunto de requisitos de caráter tecnológico e definidos pelo cliente ou por entidade de classe, que recomenda práticas ou procedimentos para projeto, produção, instalação, manutenção ou utilização de produto."

Em relação às definições anteriores, percebe-se, primeiramente, que a definição é genérica no sentido de não haver distinção do termo entre materiais e serviços. Uma outra mudança em relação à versão anterior do SiQ é a supressão da entidade de normalização como um dos possíveis responsáveis pela definição dos referenciais tecnológicos, além de estar explícito na definição que se trata de um documento não normativo. Esse caminho foi tomado pois se entendeu que os referenciais tecnológicos, no momento atual, estão ainda em desenvolvimento e consolidação, e que seria precipitado vinculá-los a normas ou a iniciativas vinculadas a entidades de normalização. Por outro lado, a definição valoriza ações definidas por clientes, como no caso da CDHU, ou de entidades de classe, que devem ter um papel ativo no processo de sua elaboração. Atinha-se, igualmente, com a

\footnotetext{
${ }^{10}$ Cliente: "Pessoa física ou jurídica para quem a empresa solicitante trabalha. Pode ou não corresponder ao usuário final do produto projetado e construído" (SiQ, 2002).
} 
idéia da diversidade dos referenciais quanto aos seus tipos funcionais, conforme será melhor discutido no Capítulo 3.

Considerando essa nova definição aplicada não à especificação de materiais, mas sim focada no processo de produção de um produto, seus termos induzem a uma idéia de abordagem mais ampla, uma vez que inclui recomendação de práticas ou procedimentos que podem envolver diferentes etapas desse processo: projeto, produção, instalação, manutenção ou utilização de produto; enquanto as versões anteriores dos referenciais tecnológicos de serviços de execução definiam requisitos apenas para o controle de produção e de recebimento de tais serviços.

Com relação à exigência dos Referenciais Tecnológicos pelo PBQP-H, consta do "Regimento Específico do SiAC da Especialidade Técnica Execução de Obras" "11 que quando estes vierem a existir e forem reconhecidos pela Comissão Nacional ${ }^{12}$, podendo ser referentes a materiais, componentes, equipamentos de obras e serviços de execução, os mesmos devem ser considerados nas auditorias para a certificação da conformidade do sistema de gestão da qualidade das empresas construtoras. Isso mostra uma clara valorização dos referenciais tecnológicos por parte do SiAC.

Verifica-se que a implantação de especificações do produto, procedimentos de execução e de controle pelas empresas construtoras vai ao encontro dos conceitos de controle e de garantia da qualidade, tornando-se obrigatória nos referenciais normativos dos sistemas evolutivos da qualidade, tanto do Programa QUALIHAB quanto do PBQP-H. De fato, em relação a este último, mesmo na versão já alinhada com a NBR ISO 9001:2000 do Sistema de Qualificação de Empresas de Serviços e Obras Construtoras (SiC-Construtoras) e agora na do Sistema de Avaliação da Conformidade de Empresas de Serviços e Obras da Construção Civil - Construtoras (SiAC-Construtoras), que aborda a gestão da qualidade, continua-se a exigir a implantação de procedimentos documentados de execução e de controle dos chamados "serviços de execução controlados".

Assim, vista a inserção dos referenciais tecnológicos nos Programas QUALIHAB e PBQP-H e a interface dos mesmos com as questões relativas à qualidade, ressalta-se que, além da qualidade do processo de produção, também é importante que os documentos técnicos de referência considerem aspectos relativos ao desempenho dos produtos.

\footnotetext{
${ }^{11}$ Esse Regimento Específico é parte integrante do Regimento Geral (Anexo II). A citação feita no texto é encontrada no Art. 24 de tal Regimento Específico do SiAC.

12 Comissão Nacional $(\mathrm{CN})$ : "Instância do SiAC de caráter neutro, constituída por representantes de contratantes, fornecedores e entidades de apoio técnico da Construção Civil, que tem como objetivos principais zelar pelo funcionamento do Sistema de Avaliação da Conformidade e fazê-lo progredir." (Regimento Geral do SiAC, Capítulo II - Das definições).
} 


\subsection{O conceito de desempenho na construção de edifícios e o desenvolvimento de referenciais tecnológicos}

A preocupação com o desempenho dos edifícios está cada vez maior, no país, nos dias de hoje. Nesse sentido, os referenciais tecnológicos podem contribuir com a formalização e disseminação de critérios e requisitos de desempenho.

Portanto, são a seguir apresentados alguns conceitos sobre desempenho, visando ao entendimento do termo e à contextualização de seu atual emprego na construção de edifícios, particularmente para a construção habitacional, já que inclui a descrição do processo de elaboração de um projeto de norma de desempenho para habitações no Brasil.

Primeiramente, quanto à questão conceitual do desempenho, tem-se que esta já foi abordada por diversos autores brasileiros, sendo sistematizada pelo então chamado Conseil International du Bâtiment (CIB) nos anos 70. A palavra 'desempenho', segundo o CIB (1975) apud Souza (1983), significa "comportamento em utilização", caracterizando que um produto deve apresentar certas propriedades que lhe permitam cumprir a sua função quando submetido a determinadas influências ou ações durante sua vida útil.

A aplicação do conceito de desempenho no processo da construção tem o potencial de produzir edifícios melhores, uma vez que existe a possibilidade de identificação mais precisa das exigências humanas e das ações externas que agem nos edifícios e, por conseqüência, dos requisitos e critérios de desempenho a serem observados. Assim, a utilização de tal conceito, de acordo com Souza (1983), implica em definir quais as condições a serem satisfeitas pelo produto, tanto a nível qualitativo quanto quantitativo, quando submetido a condições normais de uso.

Sabendo-se que tanto o edifício quanto suas partes constituintes possuem determinadas propriedades e características que influenciam o modo como elas reagem às condições de exposição, ou seja, às ações a que estão submetidas durante sua vida útil, existe a possibilidade de prever o suposto comportamento do edifício, isto é, realizar uma avaliação do seu provável desempenho quanto aos seus componentes, elementos ou sistemas construtivos. Essa avaliação, segundo Souza (1982), é baseada em requisitos e critérios de desempenho, bem como em métodos de avaliação que permitem verificar se o edifício e suas partes atendem às condições estabelecidas. Nesse contexto, na época em questão, foi desenvolvido um estudo por Sabbatini (1984), o qual obteve alguns parâmetros de desempenho relacionados às paredes de alvenaria estrutural sílico-calcárea, como isolamento térmico e acústico, resistência ao fogo, resistência estrutural e permeabilidade à água de chuva. 

conhecimento

Segundo Mitidieri Filho (1998), apesar de algumas iniciativas implementadas nos anos 30 e 40, o conceito de desempenho aplicado à construção, do modo como era conhecido à sua época e se conhece hoje, data do final da década de 60. O autor ainda cita que o uso da expressão inglesa "performance requirements" data de 1930 e que ações internacionais começaram a ser desenvolvidas a partir de 1960 pelo CIB, alguns institutos de pesquisas como o Centre Scientifique et Technique du Bâtiment (CSTB) na França, outros europeus e americanos, e pelo National Bureau of Standards (NBS), tendo-se uma normalização de desempenho desde 1979 pela ISO (Comitê ISO/TC59).

No Brasil, a questão do desempenho foi inicialmente abordada de forma sistemática pelo IPT, no início dos anos 80, quando foram estabelecidas diretrizes para avaliação do desempenho de soluções inovadoras para habitações térreas unifamiliares. Em 1981 foi concluído um trabalho do IPT para o $\mathrm{BNH}$, que objetivava definir, pela primeira vez no país, critérios técnicos que norteassem a aprovação e financiamento de construções de caráter social. Este trabalho foi desenvolvido com base na normalização ISO, definindo-se 14 parâmetros de desempenho para habitações populares, os quais, por serem tecnicamente rigorosos, não se "ajustaram" ao perfil do programa habitacional do Brasil na época. Percebe-se que tal trabalho pode ser considerado como uma tentativa de elaboração de referenciais tecnológicos para o desempenho da construção habitacional, uma vez que houve um estudo visando à definição de parâmetros de desempenho e foram constituídos documentos técnicos de referência, mesmo que estes não tenham sido, efetivamente, aplicados.

A partir de então, foram desenvolvidos diversos estudos que levaram à conclusão, em 1995, de outro trabalho realizado pelo IPT, desta vez com o apoio da FINEP, sobre normas mínimas de desempenho, intitulado: "Elaboração de Normas Mínimas de Desempenho para Habitações de Interesse Social”. A seguir, em 1998, foi publicado mais um importante documento de referência, então denominado: "Critérios Mínimos de Desempenho para Habitações Térreas de Interesse Social"13, o qual baseava-se no trabalho de 1995, já citado. Tal publicação, sob a forma de "texto para discussão", foi apresentada como proposta para um debate nacional sobre a futura qualidade da habitação popular, representando, como citado no próprio trabalho, "avanços e aprimoramentos em relação a pesquisas realizadas no início da década de 80". Este estudo, segundo IPT (1998), aborda a avaliação de desempenho traduzida em seis exigências dos usuários: desempenho estrutural, estanqueidade à água, segurança ao fogo, conforto térmico, conforto acústico e durabilidade, sendo um documento técnico de referência até os dias atuais.

\footnotetext{
${ }^{13}$ Este trabalho, realizado pelo IPT, teve o apoio da FINEP e do então Ministério do Planejamento e Orçamento (MPO) por intermédio da Secretaria de Políticas Urbanas (SEPURB), no âmbito do PBQP-H, o qual estava no início de sua estruturação.
} 
Esse contexto, de evolução dos trabalhos relativos ao desempenho das construções habitacionais, deu início à etapa de elaboração de uma norma técnica, como um aprimoramento da documentação de referência já existente e um aumento da abrangência da mesma a nível nacional. O desenvolvimento dessa norma é um marco importante, particularmente para o presente trabalho, devido à sua interface com os referenciais tecnológicos no que diz respeito, por exemplo, à definição de padrões técnicos delimitados que poderão ser incorporados a documentos técnicos não normativos e, se necessário, adaptados para diferentes regiões do país.

Assim, para dar início à elaboração de tal norma relativa ao desempenho de edificações no Brasil foi constituída uma Comissão de Estudos, formalmente, em 2001. Desde então, e ainda em 2006, está em curso um amplo processo de discussão e revisão do projeto de norma, denominado: "Projeto de Norma 02:136.01.001:2002: Desempenho de edifícios habitacionais de até cinco pavimentos ${ }^{14 ”,}$, no âmbito do Comitê Brasileiro de Construção Civil (COBRACON) / CB-02.

Segundo Borges (2004), o desenvolvimento de uma norma de desempenho surgiu da necessidade de algumas ações como: avaliação de produtos, os quais eram avaliados a partir da referência de produtos tradicionais; elaboração de normas e códigos de obra; metodologia de controle de qualidade e composição de metodologias de projeto. Vê-se, de acordo com a exposição do autor, atual responsável pela condução do processo de criação da norma, que a falta de alguns referenciais tecnológicos, como códigos de obra, colaboraram para a iniciativa de desenvolvimento dessa normalização. E, como conseqüência, a implementação de tal norma poderá contribuir para a complementação das lacunas que existiam nas documentações técnicas de referência.

De acordo com o próprio Projeto de Norma 02:136.01.001, em sua versão de julho de 2004, as normas de desempenho são estabelecidas com base nas respostas que um produto deva apresentar, independentemente dos seus materiais constituintes e do processo de produção. O projeto de norma incorpora a definição dada pelo CIB em 1975, ou seja, entende-se o conceito de desempenho como sendo o "comportamento em uso de um produto". Portanto, para o caso da habitação, é necessário explicitar as qualidades minimamente necessárias para que sejam atendidas as condições básicas de segurança, saúde, higiene e bem-estar dos usuários.

Ainda segundo tal projeto de norma, a normalização de desempenho para habitações visa alavancar tecnicamente a qualidade requerida e a oferta de moradias, estabelecendo-se regras claras e objetivas

\footnotetext{
${ }^{14}$ Apesar do Projeto de Norma 02:136.01.001:2002 ser intitulado como sendo para edifícios habitacionais de até cinco pavimentos, com exceção dos critérios que dependam diretamente da altura do edifício (segurança estrutural - estado limite último; segurança contra incêndio - rotas de fuga, equipamentos de extinção, etc.), os demais critérios poderão ser aplicados também para edifícios habitacionais com mais de cinco pavimentos, conforme especificado no próprio documento.
} 

conhecimento

para quem vai desenvolver, produzir, financiar ou ocupar e manter um imóvel habitacional. Em relação ao setor público, tem-se o objetivo inclusive de equalizar, a nível nacional, os parâmetros que norteiam os investimentos em habitações de interesse social, respeitando-se as características regionais e considerando a realidade social, econômica e industrial do país. Observa-se, portanto, que esses objetivos estão bastante próximos do que se almeja com o desenvolvimento de determinados referenciais tecnológicos, isto é, servir como padrões para cada um dos diversos agentes da cadeia produtiva da construção civil, desde quem produz a habitação até quem a utiliza e mantém, homogeneizando alguns parâmetros na construção habitacional, particularmente para a habitação de interesse social.

Para tanto, o projeto de norma define os requisitos ${ }^{15}$ e critérios ${ }^{16}$ de desempenho que se aplicam ao edifício habitacional como um todo, e que não podem ser avaliados de forma isolada para um ou mais elementos específicos, sendo composta pelas seguintes partes: Parte 1 - Requisitos gerais, Parte 2 Estrutura, Parte 3 - Pisos internos, Parte 4 - Fachadas e paredes internas, Parte 5 - Coberturas e Parte 6 - Sistemas hidrossanitários.

Para os diferentes elementos e partes da construção estabelecem-se níveis mínimos de desempenho ("Nível M"), os quais devem ser obrigatoriamente atendidos. No caso de diferentes possibilidades de agregação de qualidade aos produtos e diferentes relações custo / benefício, a exigência de desempenho pode ser excedente às necessidades mínimas, podendo atender respectivamente aos níveis de desempenho "I" (intermediário) e "S" (superior).

Portanto, o nível de desempenho pretendido para cada caso deve ser previamente definido pelos agentes públicos financiadores e promotores de habitação, bem como pelos incorporadores em geral, ou pelo próprio usuário final, no caso da construção auto-gerida. Os projetistas, em consenso com os respectivos construtores / fabricantes, devem indicar o nível de desempenho e da vida útil de projeto explicitamente nas suas especificações. Posteriormente, para avaliar o desempenho indicado, deve-se submeter a edificação ou suas partes constituintes a uma investigação sistemática baseada em métodos consistentes, capazes de produzir uma interpretação objetiva sobre o comportamento esperado do produto nas condições de uso definidas. Em função disso, a avaliação de desempenho exige o domínio de uma ampla base de conhecimentos científicos e tecnológicos sobre cada aspecto funcional de uma

\footnotetext{
${ }^{15}$ Requisitos de desempenho: "condições qualitativas que devem ser cumpridas pela habitação, a fim de que sejam satisfeitas as exigências do usuário". (Projeto de Norma 02:136.01.001, julho de 2004)

${ }^{16}$ Critérios de desempenho: "conjunto de especificações e procedimentos que visam representar tecnicamente as exigências do usuário segundo as Normas Técnicas vigentes. São expressos de forma a possibilitar a análise objetiva do atendimento ou não às exigências estabelecidas." (Projeto de Norma 02:136.01.001, julho de 2004)
} 
edificação, sobre materiais e técnicas de construção, bem como sobre as diferentes exigências dos usuários nas mais diversas condições de uso.

Embora o Projeto de Norma esteja voltado a edifícios habitacionais, os conceitos básicos que ensejam os aspectos como os destacados acima são válidos para outros tipos de edifícios. Os parâmetros adequados a estes, em função de seu uso, é que variam, devendo, no futuro, ser motivo de normas específicas, principalmente no caso de edifícios de uso público, como instituições de ensino, de saúde, etc.

Assim, percebe-se que é importante que a elaboração dessas normas pressuponha que, além de serem documentos técnicos de referência com definições de requisitos e critérios de desempenho, sejam um meio para consolidar e disseminar o conhecimento adquirido por pesquisadores no âmbito acadêmico para os profissionais e empresas que atuam no mercado da construção, como projetistas e construtores por exemplo. Desse modo, integrar essa "ponte" que realiza a difusão da informação e do conhecimento científico e tecnológico também é um dos alvos almejados pelos referenciais tecnológicos, conforme apresentado no item a seguir.

\subsection{Interface dos referenciais tecnológicos com a gestão do conhecimento na construção de edifícios}

Não é sem motivo que a gestão do conhecimento tem se tornado tema dos mais relevantes na discussão acadêmica e empresarial. Se, segundo Toffler $(1980)^{17}$, as forças determinantes da riqueza e do poder foram a terra, o capital e o trabalho durante os períodos que ele chamou de primeira e segunda ondas, agora, desde o final do milênio, na terceira onda, a sociedade da informação, prevista por Peter Druker ${ }^{18}$, está se manifestando com todo o seu vigor e destacando o papel chave desempenhado pelo conhecimento (ORSI, 2003).

Essa idéia também é abordada por Perrotti (2004), o qual apresenta a existência de três eras econômicas distintas: era da agricultura, era da indústria e era do conhecimento; marcadas, respectivamente, pelas revoluções agrícola, industrial e da informação.

A Tabela 4, a seguir, mostra um comparativo entre os paradigmas da era industrial e da era do conhecimento, apontando diferenças marcantes nos sistemas de produção.

\footnotetext{
${ }^{17}$ Toffler, Alvin. A terceira onda. Record, 1980. (apud Orsi, 2003)

${ }^{18}$ Druker, Peter et al. Gestão do conhecimento - o advento da nova organização. Harvard Business Review. Campus, 2001. (apud Orsi, 2003)
} 
Tabela 4 - Os princípios da organização baseada no conhecimento.

(Fonte: Adaptado de Sveiby, K.E. The new organizational wealth: managing and measuring knowledge-based Assets, Berrett-Koehler Publishers, Inc., San Francisco, 1997 apud Pereira, 2003)

\begin{tabular}{l|l|l}
\hline \multicolumn{1}{c|}{ Item } & \multicolumn{1}{c|}{\begin{tabular}{c}
\multicolumn{1}{c|}{ Paradigma da } \\
era industrial
\end{tabular}} & \multicolumn{1}{c}{$\begin{array}{c}\text { Paradigma da } \\
\text { era do conhecimento }\end{array}$} \\
\hline Pessoas & Geradores de custos ou recursos & Geradores de receitas \\
\hline Informação & Instrumento de controle & $\begin{array}{l}\text { Ferramenta para a comunicação: } \\
\text { recurso }\end{array}$ \\
\hline Produção & $\begin{array}{l}\text { Operários processando recursos } \\
\text { físicos para criar produtos } \\
\text { tangíveis }\end{array}$ & $\begin{array}{l}\text { Trabalhadores do conhecimento } \\
\text { convertendo conhecimento em } \\
\text { estruturas intangíveis }\end{array}$ \\
\hline $\begin{array}{l}\text { Fluxo de } \\
\text { informação }\end{array}$ & $\begin{array}{l}\text { Mediante a hierarquia } \\
\text { organizacional }\end{array}$ & Mediante redes colegiadas \\
\hline $\begin{array}{l}\text { Gargalos da } \\
\text { produção }\end{array}$ & $\begin{array}{l}\text { Capital financeiro e habilidades } \\
\text { humanas }\end{array}$ & Tempo e conhecimento \\
\hline Fluxo da produção & $\begin{array}{l}\text { Direcionado pelas máquinas; } \\
\text { seqüencial }\end{array}$ & Direcionado pelas idéias; caótico \\
\hline $\begin{array}{l}\text { Relações com os } \\
\text { clientes }\end{array}$ & $\begin{array}{l}\text { Unidirecional através dos } \\
\text { mercados }\end{array}$ & $\begin{array}{l}\text { Interativa através de redes } \\
\text { pessoais }\end{array}$ \\
\hline Conhecimento & $\begin{array}{l}\text { Uma ferramenta ou recurso entre } \\
\text { outros }\end{array}$ & O foco do negócio \\
\hline
\end{tabular}

Portanto, os novos paradigmas da atual era da informação e do conhecimento justificam o crescimento exponencial pelo tema na última década. Tem-se, ainda, uma ligação entre competitividade e conhecimento, sendo este um diferencial para as empresas, já que a grande exigência de capacidade competitiva do mundo moderno as obriga a terem uma grande capacidade de aprender. Além disso, o desenvolvimento intenso de novas tecnologias, a contínua inovação dos produtos e a necessidade de se aumentar a competitividade para atender a uma demanda do mercado cada mais exigente, requer das empresas a busca permanente do conhecimento.

É também nesse contexto que a elaboração dos referenciais tecnológicos se insere, ou seja, como forma de contribuir para a formalização e registro de conhecimentos relevantes para as empresas e agentes que integram a cadeia produtiva da construção civil, particularmente da construção de edifícios. Assim, os documentos técnicos de referência auxiliam na consolidação e na difusão do conhecimento, visando à disseminação de práticas bem sucedidas empregadas no processo de produção dos edifícios, organizando e divulgando informações que possam colaborar com a melhoria da qualidade do processo e do desempenho do produto final.

Segundo Santiago (2002), a finalidade do registro é colocar o conhecimento em formato utilizável para que, a partir daí, as empresas possam mensurar sua possível utilização. Para o caso do presente 
trabalho, entende-se que as empresas consideradas podem ser, por exemplo, desde empreendedores, projetistas, construtoras, gerenciadoras até entidades de classe e clientes finais.

É importante destacar a diferença entre os registros de dados, informações ou conhecimentos. De acordo com Teixeira Filho (2000), de modo bastante simplificado, 'dado' é um valor sem significado, 'informação' é um dado com significado e 'conhecimento' é uma informação estruturada e contextualizada. Para o autor, o conhecimento é o elemento habilitador da decisão. Entretanto, muitas vezes o que existe nas empresas é uma enorme quantidade de dados que, por não serem interpretados e não estarem associados a nenhum contexto nas organizações, acabam não sendo utilizados e nem proporcionando informações ou conhecimentos relevantes para a tomada de decisões.

No caso, o foco aqui é dado para o conhecimento, o qual subdivide-se em duas formas complementares elucidadas por Nonaka e Takeuchi (1997): conhecimento explícito e conhecimento tácito. Segundo os autores, a diferenca dos dois formatos mencionados situa-se no fato de que o conhecimento explícito pode ser articulado na linguagem formal e sistemática, inclusive em afirmações gramaticais, expressões matemáticas, especificações, manuais e assim por diante, enquanto o conhecimento tácito é difícil de ser formulado ou comunicado, sendo um conhecimento pessoal e específico ao contexto, incorporado à experiência individual envolvendo fatores intangíveis, como, por exemplo, crenças pessoais, perspectivas e sistemas de valor.

Assim, conforme ressaltado por Santiago (2002), o resgate do conhecimento explícito se consegue através da codificação deste por meio de relatórios, documentos e procedimentos prescritivos; o que se correlaciona, neste trabalho, ao desenvolvimento dos referenciais tecnológicos no âmbito da construção de edifícios. Desta forma, todas as atividades e processos funcionais podem ser escritos de maneira clara e de fácil entendimento para que sejam utilizados pelos demais profissionais do setor. Já o conhecimento tácito, por se encontrar exclusivamente na cabeça das pessoas, compreende um processo mais complexo para a sua captura exigindo intenso contato entre as pessoas.

Quanto ao processo ou ciclo do conhecimento, tem-se que este se apresenta segundo um modelo dividido em quatro grandes fases: geração; captura e análise; síntese e arquivo; disseminação e uso (PERROTTI, 2004). Entretanto, o termo 'gestão do conhecimento' é relativamente novo, e ainda existem controvérsias quanto a sua definição. Adota-se aqui a definição de Machado Neto (1998): "conjunto de estratégias para criar, adquirir, compartilhar e utilizar ativos de conhecimento, bem como estabelecer fluxos que garantam a informação necessária no tempo e formato adequados, a fim de auxiliar na geração de idéias, solução de problemas e tomada de decisão". 
Atualmente, muitas empresas já reconhecem a necessidade de gerir o conhecimento e o quanto fundamental é para elas se estruturarem e adotarem essa prática de gestão. Dentre os processos que compõem a gestão do conhecimento, a etapa de compartilhamento do conhecimento é essencial, sendo responsável pela multiplicação dos conhecimentos já existentes, por promover a utilização dos mesmos e, indiretamente, também por estimular a criação de novos conhecimentos. Ressalta-se, aqui, mais uma vez a interface com a implementação de referenciais tecnológicos para a construção de edifícios, sendo que estes devem estar incorporados na cultura das empresas do setor.

Para a gestão do conhecimento em si, a Internet possui grande importância quanto à captação, o armazenamento e principalmente a difusão dos conhecimentos, ainda mais pelo seu grande potencial de incrementar a interação dos indivíduos nas organizações, o que também colabora para a criação do conhecimento (SANTIAGO, 2002). Ainda segundo o autor, a utilização da tecnologia da informação para a gestão do conhecimento está justamente associada ao objetivo de "criar novo conhecimento, disseminá-lo na organização e incorporá-lo nas atividades, serviços e produtos da organização". Assim, a tecnologia possui um papel de facilitar fortemente a criação, registro e disseminação do conhecimento ao permitir que todos na organização possam fazer parte deste processo em qualquer instante e independente de sua localização.

Portanto, os referenciais tecnológicos podem estar inseridos, inclusive, na Internet, desde que estejam devidamente organizados para facilitar o acesso aos documentos, abrangendo assim uma gama maior de pessoas que serão beneficiadas com tal conhecimento. Entretanto, quanto aos sistemas voltados à difusão de boas tecnologias, Amorim (2002) expõe que para a difusão de experiências não basta a publicação de relatórios técnicos, sendo preciso formatar a informação de modo compatível com o interesse dos usuários e definir padrões para consolidar esse gênero de informação. $\mathrm{O}$ autor ainda cita que a utilização da tecnologia da informação como instrumento de melhoria do ambiente construído e de integração na América Latina ainda está no campo das potencialidades, necessitando de maiores investimentos nesse sentido.

Assim, melhorar a comunicação, a troca e a integração da informação são desafios técnicos e organizacionais que devem ser superados. Um desses desafios, para Tristão et al (2005), é a padronização de estruturas de informação para a indústria da construção, o que envolve definir a linguagem que pode ser usada para comunicar informação entre diversas partes. Sob este tópico amplo, os autores apresentam esforços de padronização que estão atualmente a caminho. Relata que o trabalho de padronização para troca e comunicação de dados na construção civil tem sido conduzido pelo CIB - W78 e pelo comitê da ISO TC 59 - sub-comitê SC-13 que é responsável pela organização 
da informação no processo construtivo. Dois documentos importantes foram publicados, a ISO TR $14117 / 1994^{19}$ - Classificação da informação na indústria da construção, depois de revisada foi publicada numa versão mais resumida como ISO DIS 12006-2 - Organization of information about construction works - Part 2: Framework for classification of information. Segundo os autores, ambos documentos vêm servindo de linha orientadora para os desenvolvimentos mundiais no assunto.

Ainda de acordo com Tristão et al (2005), na ISO o comitê TC 59 - Building Construction é responsável pela padronização nos seguintes campos:

- terminologia para edifícios e engenharia civil;

- organização da informação no processo construtivo: projeto, produção, manutenção e demolição;

- definição das exigências geométricas gerais para edifícios e engenharia civil, incluindo coordenação modular (os seus princípios básicos), regras gerais para juntas, tolerâncias e forma; e

- elaboração de regras gerais de desempenho para edifícios e obras de engenharia civil.

Com relação a isso, tem-se que todos esses campos citados inserem-se no contexto do presente trabalho, podendo contribuir para a elaboração de referenciais tecnológicos para a construção de edifícios. Inclusive, quanto aos dois primeiros campos, com relação à terminologia e organização da informação, encontra-se em andamento um Projeto denominado "Desenvolvimento de Terminologia e

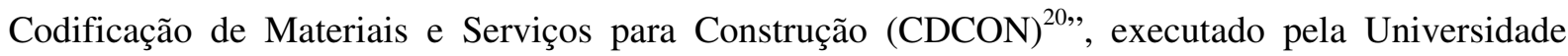
Federal Fluminense (UFF), sob a coordenação do prof. Dr. Sérgio Roberto Leusin de Amorim. O objetivo desse Projeto é obter um consenso em torno de uma sistemática padronizada para terminologia e uma norma de conteúdo para a codificação da construção, visando que esta se torne um projeto de Norma Brasileira. Portanto, o CDCON pretende elaborar a terminologia do segmento edificações, padronizar a classificação e codificação de materiais e serviços para construção e estabelecer um vocabulário controlado. Desse modo, o Projeto pretende atingir um consenso e estabelecer, senão uma referência única nestes aspectos, ao menos uma sistemática comum que

\footnotetext{
${ }^{19}$ INTERNATIONAL ORGANIZATION FOR STANDARDIZATION. ISO Technical Report 14177:1994: Classification of Information in the construction industry. Geneva, 1994.

${ }^{20}$ Informações a respeito desse Projeto disponíveis em: <http://www.cdcon.ufjf.br>. Acesso em: 5/1/2006.
} 
Capítulo 2 - Inserção de referenciais tecnológicos na construção de edifícios: qualidade, desempenho e gestão do conhecimento

permita uma plena compatibilidade entre os sistemas, o que torna essencial a participação de diversas entidades de classe de agentes do setor ${ }^{21}$.

Ainda com relação ao CDCON, um de seus aspectos importantes é a possibilidade de implantar uma gestão de conhecimento na construção, baseada em uma terminologia plenamente aceita e interrelacionada com produtos e serviços (ver Figura 5).

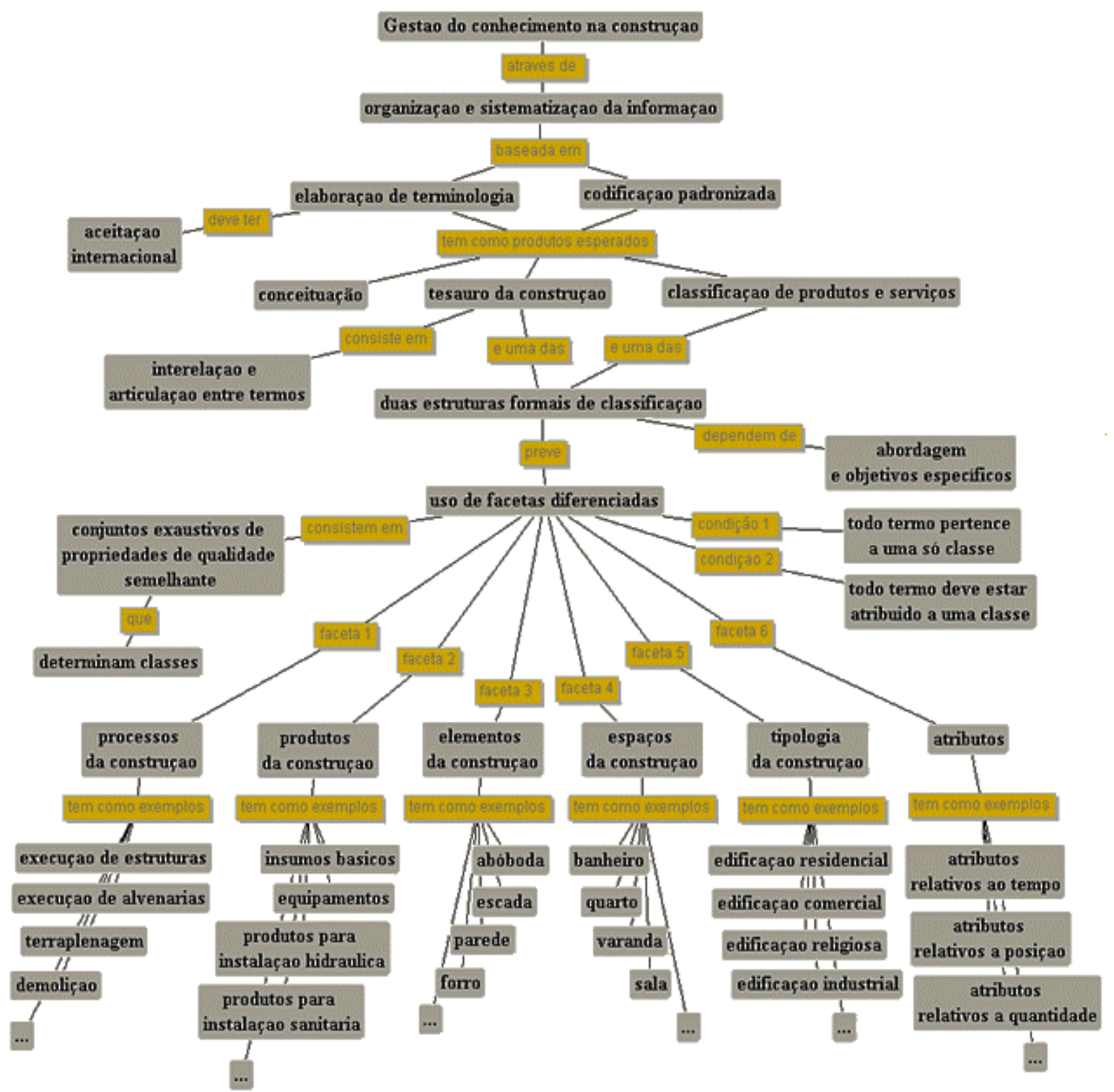

Figura 5 - Árvore do conhecimento elaborada pelo CDCON.

(Fonte: http://www.cdcon.ufjf.br/projeto/aconhecimento.php)

\footnotetext{
${ }^{21}$ Este Projeto é liderado pela Associação Nacional de Tecnologia do Ambiente Construído (ANTAC), concebido em resposta a um Edital da linha HABITARE, da FINEP, e apoiado também pelo Conselho Nacional de Desenvolvimento Científico e Tecnológico (CNPq), Ministério da Ciência e Tecnologia (MCT) e Associação Nacional dos Comerciantes de Material de Construção (ANAMACO). Têm-se ainda como co-executores: Universidade Federal de Juiz de Fora (UFJF), Universidade do Rio Grande do Sul (UFRG), Universidade Federal de Santa Catarina (UFSC) e Associação Nacional dos Comerciantes de Material de Construção (ANAMACO).
} 
$\mathrm{Na}$ Figura 5, também se observa que o CDCON criou a classificação por facetas, no intuito de se obter esquemas de classificação que possam acompanhar as mudanças e a evolução do conhecimento, sendo que uma dessas facetas refere-se aos processos da construção, descrevendo os processos ao longo de todo o ciclo de vida do espaço construído (desde sua concepção até a demolição ou reciclagem), o que se aproxima do tema abordado no presente trabalho.

Nesse contexto, relacionado ao uso de uma terminologia aceita e à formalização das informações e do conhecimento por meio de documentos, Amorim (1995) já destacava: "é preciso que os atores tenham um código comum, uma linguagem de representação das situações abordadas que seja a mais uniforme possível, para garantir a uniformidade dos objetivos da cadeia de produção, ou seja, sua convergência". Portanto, é necessário criar instâncias que diminuam a possibilidade de conflitos e "ruídos" na transmissão das informações, uma vez que existem diversas interfaces que relacionam atividades onde participam mais de um desses atores: incorporador, arquiteto, gerenciador, empresa construtora, subcontratados, dentre outros. Além disso, ainda segundo Amorim (1995), a situação das edificações no Brasil, na fase de execução da construção, ainda possui formas de transmissão da informação, primordialmente, verbais, ou seja, pouco documentada; realidade esta que não se alterou substancialmente nestes últimos dez anos. Assim, entende-se no presente estudo que a implementação dos documentos técnicos de referência no decorrer do processo de produção dos edifícios possa contribuir para facilitar a formalização e a circulação de informação e conhecimento, de modo eficiente e homogêneo, onde todos "falem a mesma língua".

Conclui-se, desse capítulo, que a atual abordagem e relevância da utilização dos conceitos de gestão do conhecimento, desempenho e gestão da qualidade no setor da construção de edifícios no Brasil, têm que ser motivo de uma reflexão de modo a embasar a elaboração de documentos técnicos de referência, consolidando ‘boas práticas’ para projeto, execução e controle de componentes, elementos ou sistemas construtivos. Ou seja, é importante que tais documentos utilizados no processo de produção de edifícios contenham, por exemplo, especificações do produto, procedimentos de execução e controle de serviços que visem à qualidade e à garantia do desempenho do produto final, além de formalizar e disseminar o conhecimento para o setor. Alguns documentos técnicos de referência são analisados no Capítulo 3, a seguir, buscando caracterizá-los e perceber, dentre outros aspectos, em que medidas atendem a este preceito. 


\section{Capítulo 3}

\section{REFERENCIAIS TECNOLÓGICOS PARA A CONSTRUÇÃo DE EDIFÍCIOS}

O desenvolvimento de referenciais tecnológicos, como documentação técnica de referência, foi um dos temas apontados pela ANTAC (2003), no Seminário "Cidades, Ciência e Tecnologia", como uma das prioridades em termos de desenvolvimento científico e tecnológico na área de construção para o Brasil.

Nesse sentido, por meio de pesquisas bibliográficas, verificou-se que, apesar de ainda serem uma prioridade para o país, algumas iniciativas no sentido de elaborar documentos técnicos de referência já foram ou tentaram ser implementadas no Brasil. Assim, o presente capítulo apresenta uma breve caracterização do estado-da-arte de tais documentos, sendo o termo "estado-da-arte" entendido como o "nível de desenvolvimento atingido (por uma ciência, uma técnica) na atualidade", conforme definição de Ferreira (2004).

Salienta-se, porém, que não se pretende esgotar o assunto, muito menos abranger todo e qualquer tipo de documento técnico de referência existente. Pretende-se, sim, colocar em pauta o tema, atualizando alguns conceitos, bem como apresentar e discutir alguns documentos considerados relevantes.

Assim, além das experiências nacionais, verificou-se que tais documentos são amplamente utilizados em outros países, particularmente nos países desenvolvidos, dos quais alguns já possuem extensa experiência nessa área. Portanto, esse capítulo também tem como objetivo levantar algumas experiências estrangeiras que possam servir como referência para o Brasil, balizando o desenvolvimento de iniciativas que incorporem idéias já consolidadas no exterior.

No entanto, antes de apresentar as experiências estrangeiras e nacionais quanto aos documentos técnicos de referência, é preciso ressaltar que existem diferentes tipos funcionais desses documentos, podendo estes ser de naturezas distintas, com foco, objetivo, público alvo ou campo de atuação também distintos. 
Considera-se, aqui, a definição de documento adotada pela NBR ISO 9000:2000, na qual documento é a "informação (dados significativos) e o meio no qual ela está contida"; sendo que, atualmente, esse meio pode também ser virtual, como Internet e softwares.

Assim, quanto aos tipos de documentos tem-se, por exemplo, os utilizados em sistemas de gestão da qualidade, de acordo com a NBR ISO 9000:2000:

- “documentos que estabelecem requisitos; tais documentos são referidos como especificações;

- documentos que estabelecem recomendações ou sugestões; tais documentos são referidos como diretrizes;

- documentos que fornecem informações sobre como realizar atividades e processos de forma consistente; tais documentos podem incluir procedimentos documentados, instruções de trabalho e desenhos."

Para Barros (1996), a existência de determinados documentos pode auxiliar na redução da variabilidade do processo de produção, passando pela sua padronização. Dentre eles, estão os que se referem aos seguintes procedimentos de produção: de projeto, de execução dos serviços e de controle.

Considera-se, entretanto, de maneira simplista, as seguintes etapas do processo de produção e ciclo de vida de um edifício, partindo-se do planejamento, projeto, execução, entrega do produto final, uso e manutenção do edifício, até a etapa de pós-uso (demolição, reforma ou reciclagem do edifício), conforme pode ser visualizado na Figura 6, a seguir.

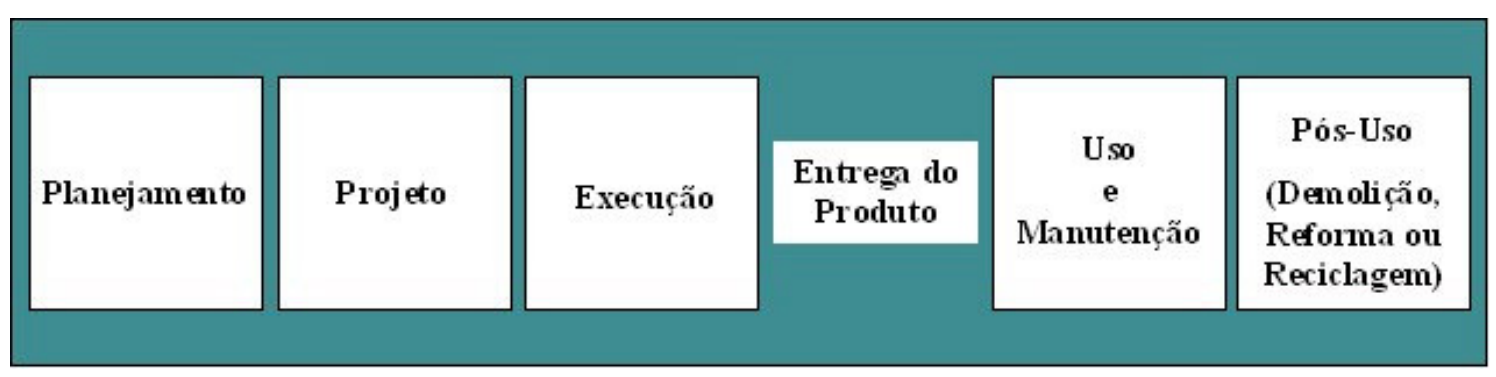

Figura 6 - Representação simplificada das etapas do processo de produção de um edifício.

Assim, por exemplo, para a etapa de projeto, são utilizados documentos técnicos de referência para a especificação do produto, visando o seu desempenho; nesta etapa também se inclui a especificação dos materiais e componentes a serem empregados na obra, podendo abranger o controle de recebimento desses produtos que deverá ser feito durante a obra. Já para a etapa de execução, é importante o uso de documentos que contenham os procedimentos adequados para a execução, bem como os que considerem as referências para o controle do processo de execução e recebimento dos serviços. O 
documento de controle do produto pode ser empregado na etapa de entrega do edifício. Na etapa de uso e manutenção do edifício são utilizados documentos que apresentem, por exemplo, procedimentos que englobem operação, manutenção e conservação do mesmo; e, posteriormente, procedimentos de demolição, reciclagem ou reforma a serem empregados na etapa de pós-uso do edifício.

Portanto, pode-se dizer que cada um desses tipos de documento está num contexto diferente, associando-se, também, tais documentos a diferentes agentes do setor, os quais têm interesses específicos. Uma discussão mais aprofundada a respeito de alguns tipos dos documentos técnicos de referência, bem como dos respectivos agentes envolvidos quando da elaboração ou utilização de cada um deles, é realizada no Capítulo 6.

No presente trabalho, considera-se, basicamente, três tipos de referenciais tecnológicos de interesse, a serem estudados neste capítulo, os quais são sintetizados na Tabela 5.

Tabela 5 - Tipos de referenciais tecnológicos estudados neste trabalho e as respectivas etapas contempladas do processo de produção.

\begin{tabular}{l|l}
\hline \multicolumn{1}{c|}{$\begin{array}{c}\text { Tipos de referenciais tecnológicos } \\
\text { para construção de edifícios }\end{array}$} & $\begin{array}{c}\text { Etapas correspondentes } \\
\text { do processo de produção }\end{array}$ \\
\hline Referenciais tecnológicos de especificação do produto & Projeto \\
\hline Referenciais tecnológicos de procedimentos de execução & Execução \\
\hline Referenciais tecnológicos de controle do processo de execução & Execução \\
\hline
\end{tabular}

Ressalta-se que documentos de procedimentos e de controles podem também ser empregados para outras etapas, como uso e pós-uso do edifício. No entanto, os mesmos não fazem parte do escopo do presente trabalho.

Assim, considerando-se a limitação da pesquisa, foram selecionados alguns documentos técnicos de referência para a construção de edifícios, constituindo experiências estrangeiras e nacionais.

\subsection{Experiências Estrangeiras}

Na legislação inglesa, conforme explicitado por HOLT (1997) apud Formoso et al (2003), tem-se a hierarquização das exigências da legislação, de acordo com o grau de detalhamento, segundo três níveis principais: normas, regulamentos e códigos de práticas.

As normas e os regulamentos são legislações, tendo os regulamentos a função de detalhar os requisitos técnicos mínimos exigíveis para cada tópico das normas, fornecendo os parâmetros para implantação e 
controle, por exemplo. Já os códigos de práticas não possuem status legal e visam à complementar as normas e os regulamentos, apresentando exemplos de boas práticas para cumprir aquelas legislações.

Desse modo, com o uso dos códigos de práticas, por exemplo, facilita-se a atualização de normas que são, muitas vezes, extensas e complexas. Os modelos de códigos de prática (model codes ou codes of practices) e guias de práticas recomendadas (best practice guides) já são amplamente utilizados em alguns países.

Primeiramente, quanto aos model codes, ou codes of practices, tem-se que seu principal objetivo é auxiliar aos órgãos governamentais, principalmente as municipalidades, a elaborarem os seus códigos de edificações e de desenvolvimento urbano, conforme exposto pela ANTAC (2003). Para tanto, existem organizações criadas para elaborar esses documentos, as quais contam com participação voluntária de vários agentes da cadeia produtiva, a exemplo do que acontece na elaboração de normas técnicas. Ressalta-se, entretanto, que os modelos de códigos têm valor legal somente se estes forem adotados pelo poder público de uma determinada jurisdição ${ }^{22}$. Em realidade, tais documentos reúnem um conjunto de códigos mais específicos, podendo estes ser relacionados ao projeto arquitetônico de edificações, instalações de prevenção de incêndio, proteção ambiental, conservação de energia, manutenção de edificações, planejamento e desenvolvimento urbano, etc.

A ANTAC (2003) ainda aponta os principais benefícios dos modelos de código de prática. São eles:

- “facilitar a elaboração da legislação local e regional referente a códigos de obras, planos diretores de desenvolvimento urbano e outros documentos semelhantes, principalmente para os municípios pequenos, que não possuem corpo técnico qualificado; e

- estabelecer parâmetros que permitam o desenvolvimento de produtos para a Construção Civil que tenham o potencial de serem comercializados em amplas regiões geográficas”.

Os codes of practices, consistem, portanto, em documentos para formalizar as boas práticas a serem adotadas na execução de determinados serviços. A maior parte desses documentos já se encontra normalizada, podendo-se citar como exemplo os códigos de práticas utilizados pelos ingleses, dos quais muitos já foram incorporados pela British Standards Institution (BSI).

${ }^{22}$ Canadia Comission on Building and Fire Codes. Canada's construction system: the context for model codes. (ANTAC, 2003) 
Existem códigos de práticas em diversos países, inclusive já sob o status de normas técnicas. A Tabela 6 , a seguir, apresenta alguns países que possuem esse tipo de documento, juntamente com um respectivo exemplo.

Tabela 6 - Exemplos de códigos de práticas estrangeiros. (Fonte: Informações obtidas em pesquisas realizadas no Banco de Dados de Normas Técnicas do IPT, 2005)

\begin{tabular}{|c|c|c|c|}
\hline País & $\begin{array}{l}\text { Organização de } \\
\text { Normalização }\end{array}$ & Identificação / Título do Documento & Data \\
\hline África do Sul & $\begin{array}{l}\text { South African Bureau of } \\
\text { Standards (SABS) }\end{array}$ & $\begin{array}{l}\text { SABS 0120-2 G: Code of Practice for Use } \\
\text { with Standardized Specifications for Civil } \\
\text { Engineering Construction and Contract } \\
\text { Documents - Part 2: Project Specification } \\
\text { Section G: Concrete (Strutural) }\end{array}$ & 1982 \\
\hline Alemanha & $\begin{array}{l}\text { Deutsches Institut fur } \\
\text { Normung (DIN) }\end{array}$ & $\begin{array}{l}\text { DIN 19667: Draenung von Deponien; } \\
\text { Technische Regeln fuer Bemessung, } \\
\text { Bauausfuehrung und Betrieb }\end{array}$ & 1991 \\
\hline Austrália & Standards Australia (SA) & $\begin{array}{l}\text { SAA/SNZ HB62-1: Code of Practice for } \\
\text { Safe Erection of Building Steelwork - Part } \\
\text { 1: Low Rise Buildings and Strutures }\end{array}$ & 1995 \\
\hline Colômbia & $\begin{array}{l}\text { Instituto Colombiano de } \\
\text { Normas Tecnicas y } \\
\text { Certificación (NTC) }\end{array}$ & $\begin{array}{l}\text { NTC 2895: Code of Practice for Concrete } \\
\text { Bases and Screeds to Receive in-situ } \\
\text { Floorings }\end{array}$ & - \\
\hline Itália & $\begin{array}{l}\text { Ente Nazionale Italiano di } \\
\text { Unifacazione }\end{array}$ & $\begin{array}{l}\text { UNICEI 70016: Codice di Buona Pratica per } \\
\text { la Valutacione della Conformitá }\end{array}$ & 1999 \\
\hline Japão & $\begin{array}{l}\text { Japanese Standards } \\
\text { Association (JSA) }\end{array}$ & $\begin{array}{l}\text { Z 8310: Technical Drawing - General Code } \\
\text { of Drawing Practice }\end{array}$ & 1984 \\
\hline Malásia & $\begin{array}{l}\text { Standards and Industrial } \\
\text { Research Institute of } \\
\text { Malaysia (SIRIM) }\end{array}$ & $\begin{array}{l}\text { MS 1195: Code of Practice for Structure Use } \\
\text { of Concrete - Part 1: Design and } \\
\text { Construction }\end{array}$ & 1991 \\
\hline $\begin{array}{l}\text { Nova } \\
\text { Zelândia }\end{array}$ & $\begin{array}{l}\text { Standards New Zealand } \\
\text { (SNZ) }\end{array}$ & $\begin{array}{l}\text { NZS } 4230 \text { - Part 1: Code of Practice for the } \\
\text { Design of Masonry Structures }\end{array}$ & 1990 \\
\hline $\begin{array}{l}\text { Reino Unido } \\
\text { (Inglaterra) }\end{array}$ & $\begin{array}{l}\text { British Standards } \\
\text { Institution (BSI) }\end{array}$ & $\begin{array}{l}\text { BS 5628-2: Code of Practice for the Use of } \\
\text { Masonry - Part 2: Structural Use of } \\
\text { Reinforced and Prestresse Masonry }\end{array}$ & 2000 \\
\hline Singapura & $\begin{array}{l}\text { Singapore Productivity } \\
\text { and Standards Board } \\
\text { (PBS) }\end{array}$ & $\begin{array}{l}\text { CP } 61 \text { - Part 2: Code of Practice for } \\
\text { Packaging and Containers for Hazardous } \\
\text { Substances }\end{array}$ & 1994 \\
\hline
\end{tabular}

Já os guias de práticas recomendadas (best practice guides) diferenciam-se das normas técnicas por não terem um caráter regulamentador e por não serem necessariamente de abrangência nacional. Isto é, segundo a ANTAC (2003), tais documentos podem ter um caráter regional, se necessário, de forma

\footnotetext{
${ }^{23}$ Título em inglês: Drainage of Landfills; Code of Practice for Design, Construction and Operation.

${ }^{24}$ Título em inglês: Code of Good Practice for Conformity Assessment.
} 
a levar em conta as diferenças regionais de clima, tecnologia e cultura. Assim, não são resultado de um processo formal e regulamentado e não seguem necessariamente os princípios da normalização técnica.

A linguagem desses documentos técnicos de referência tende a ser mais simples e direta (num nível menos abstrato) que as normas, sendo focados no atendimento das necessidades dos seus usuários (por exemplo, projetistas, engenheiros, operários, etc.). Em geral, referem-se a procedimentos consolidados no meio técnico, sobre os quais existe um consenso - raramente podem ser elaborados para tecnologias inovadoras (ANTAC, 2003). Salienta-se, ainda, que esse tipo de documento deve ser desenvolvido de forma articulada às normas técnicas, considerando-se que um sistema de normalização técnica geralmente contém dois principais tipos de normas:

- "normas de produto (materiais, componentes e alguns sistemas), as quais se subdividem em especificações de produtos e métodos de ensaio; e

- normas de procedimentos de projeto ou processo de produção. Caberia aos guias de práticas recomendadas complementar as normas de procedimentos, de forma que estas passassem a ser, em geral, documentos de tamanho relativamente reduzido, contendo apenas diretrizes mais gerais para projeto ou processos de produção. Essa estrutura de documentação é utilizada em diversos países desenvolvidos, trazendo maior dinamismo à produção do conjunto de documentos técnicos (normas técnicas e guias de boas práticas), de forma a torná-lo mais adaptável à introdução de inovações tecnológicas” (ANTAC, 2003).

Nesse contexto, conhecidos os conceitos dos códigos de práticas e guias de práticas recomendadas, são apresentados, aqui, cinco documentos técnicos de referência estrangeiros que incorporam boas práticas para a execução de edifícios. Os três primeiros referem-se aos Estados Unidos da América (EUA), o quarto à Austrália e o quinto à Inglaterra.

Quanto aos documentos do EUA, a título de esclarecimento, explica-se primeiramente, de modo sucinto, a estrutura da elaboração e do uso destes no país. Sabe-se que nos EUA existem, basicamente, três Códigos de Edificações (Building Codes) elaborados por diferentes instituições e adotados em distintas regiões do território. São eles: o National Building Code, elaborado pelo Building Officials and Code Administrators (BOCA); o Standard Building Code, sob responsabilidade do Southern Building Code Congress International (SBCCI); e o Uniform Building Code, desenvolvido pelo International Conference of Buildings Officials (ICBO). Este último código é apresentado no item 3.1.1; aos demais não foi possível se ter acesso. Recentemente, no final da década de 90, essas três instituições de caráter regional, reuniram-se e fundaram o International Code Council (ICC), no intuito de se ter uma abrangência em todo o país. O ICC, então, com o auxílio dos representantes do BOCA, SBCCI e ICBO, elaborou um documento de caráter nacional, unindo aspectos pertinentes de 
cada um dos códigos desenvolvidos pelas respectivas instituições. Este documento foi denominado International Building Code e é apresentado no item 3.1.2 do presente trabalho. Para uma melhor visualização da estrutura dos Códigos de Edificações nos EUA, ver a Figura 7, a seguir.

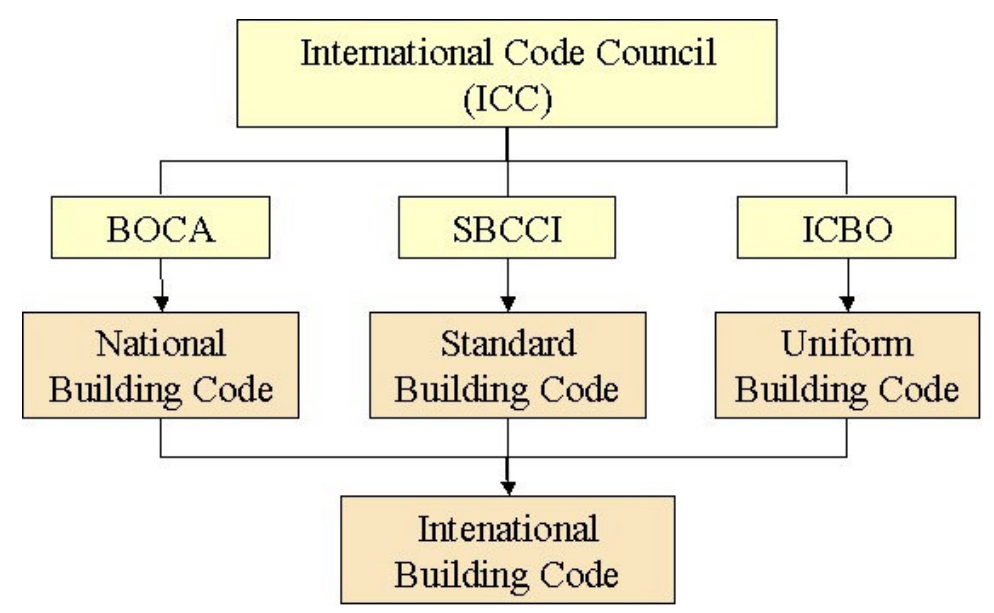

Figura 7 - Estrutura dos Códigos de Edificações nos EUA. (Fonte: William E. Koffel, P.E. Koffel Associates, Inc. in Code Update: International Building Code NFPA 5000, s.d.)

Já quanto ao terceiro documento dos EUA, a ser apresentado no item 3.1.3, trata-se de um "Manual" e não de um "Código". Percebe-se, portanto, o escopo diferenciado desse documento em relação aos dois anteriores, sendo que tal Manual recomenda boas práticas para o setor da construção civil, tendo sido elaborado por um instituto característico do setor: o Construction Specifications Institute (CSI).

Já o documento técnico de referência da Austrália é, também, um "Código de Edificações", similar às características dos dois primeiros documentos dos EUA, denominado Building Code of Australia, conforme item 3.1.4. E, por fim, o documento utilizado na Inglaterra, aqui apresentado no item 3.1.5, tem um caráter distinto dos demais, não sendo um "Code" e sim "standards", ou padrões que recomendam boas práticas da construção, elaborados por um órgão que fornece garantia e seguro para novos edifícios habitacionais no país.

A seguir, são apresentadas informações mais detalhadas a respeito de cada um desses documentos estrangeiros.

\subsubsection{Uniform Building Code}

De acordo com o prefácio do próprio documento, o norte-americano Uniform Building Code (UBC) colabora para o aprimoramento do processo de produção de edifícios e promove maior segurança aos usuários, uniformizando as leis e exigências para os edifícios. Os fundamentos desse código tornam possível o uso de produtos e sistemas inovadores; assim, materiais, projetos e métodos construtivos 
alternativos podem ser utilizados, desde que se comprove o atendimento aos requisitos de desempenho especificados (caso haja necessidade, ensaios podem ser solicitados).

O UBC foi referendado primeiramente pela International Conference of Building Officials (ICBO), na sexta reunião anual de negócios (Annual Business Meeting), realizada em Phoenix (Arizona), em outubro de 1927. Desde então, têm sido publicadas edições revisadas deste código em intervalos de, aproximadamente, três anos. As novas edições incorporam as mudanças aprovadas desde a última publicação do documento.

A elaboração do conteúdo do UBC é feita de modo que este seja compatível com as publicações relacionadas ao tema, visando fornecer um conjunto completo de documentos para uso no setor da construção civil. No próprio UBC tem-se uma lista de códigos uniformes (Uniform Codes) e documentos de referência relacionadas ao assunto, no âmbito do ICBO, que podem ser utilizados para pesquisas complementares. Tal listagem é atualizada a cada edição, visando maior conhecimento a respeito desses tipos de documentos e aprimoramento da administração de programas de inspeção em edifícios. Alguns destes códigos são publicados em parceria com outras organizações tais como o International Fire Code Institute (IFCI) e o International Code Council (ICC).

Para que sejam identificadas as alterações em relação à edição imediatamente anterior, são inseridas linhas verticais contínuas nas margens do texto válido do código, a não ser que um capítulo inteiro tenha sido revisado ou um capítulo novo tenha sido adicionado (nesses casos, uma anotação é escrita no início do respectivo capítulo).

O conteúdo da edição de 1994, a qual é analisada no presente trabalho, foi re-formatado de acordo com o formato padrão de códigos estabelecido pelo Council of American Building Officials (CABO), nos EUA.

O Uniform Building Code é subdivido em três volumes. O primeiro trata de termos administrativos, planejamento de execução do edifício, segurança ao fogo, necessidades do usuário (como acessibilidade), materiais não-estruturais (vidro, gesso, plástico) e recomendações para inspeções em campo (por exemplo, de telhados e sistemas prediais). O volume 2 contempla recomendações para projetos estruturais (fundações, contenções, requisitos para estruturas em concreto, alvenarias, estruturas em aço e em madeira). Por fim, o volume 3 contém padrões estabelecidos para materiais, bem como requisitos e métodos de ensaios, de acordo com o estabelecido pelo ICBO ou pelas normas da American Society for Testing and Materials (ASTM).

O objetivo do UBC é prover padrões mínimos de segurança, saúde e bem-estar público, uniformizando e controlando projeto, execução, qualidade de materiais, uso e ocupação, locação e manutenção dos 
edifícios regulamentados por este código. As prescrições deste documento podem ser aplicadas para construção, reforma, demolição, manutenção e uso dos edifícios em questão.

\subsubsection{International Building Code}

Segundo informações contidas no próprio documento, os "códigos oficiais" reconhecem a necessidade de serem códigos modernos e atualizados, que abranjam projeto e execução de edifícios, por meio de requisitos que visem o adequado desempenho do produto. Assim, por iniciativa do International Code Council (ICC), foi concebido, nos EUA, o International Building Code (IBC), para tentar suprir essas necessidades, apresentando regulamentos que garantam a saúde pública e a segurança.

O primeiro projeto do International Building Code foi preparado em 1997 por cinco pré-subcomitês apontados pelo ICC e que consistiam de representantes do BOCA, do ICBO e do SBCCI. O intuito era elaborar uma minuta de uma série de regulamentos para a construção de edifícios que seguissem as orientações dos códigos-modelo e que, inclusive, abrangesse os demais códigos-modelo existentes. Como base para o desenvolvimento deste documento foi utilizado o último código-modelo promulgado por cada uma das citadas instituições, bem como artigos desenvolvidos pelo Board for the Coordination of Model Codes (BCMC). Embora se percebeu que existiam muitas similaridades entre os códigos, foi despendida especial atenção com as diferenças identificadas, tendo os comitês definido critérios para a resolução das diferenças técnicas. Os critérios ou princípios foram baseados na tentativa de estabelecer requisitos compatíveis com o escopo de um código de construção civil que protegesse adequadamente a saúde pública, a segurança e o bem estar; que não aumentasse os custos da construção de forma desnecessária; que não restringissem o uso de novos materiais, técnicas ou métodos de construção; e que não dessem tratamento privilegiado para tipos ou classes particulares de materiais, produtos ou processos de execução.

No intuito de obter a opinião de usuários do código, das indústrias e demais agentes interessados do setor da construção civil, criou-se o já citado fórum de debate público. Os pré-comitês consideraram todos os comentários submetidos a esse fórum realizado em 1997. A seguir, foi realizada uma audiência pública em 1998 e duas em 1999. Os subcomitês técnicos consideraram as contribuições efetuadas tanto no fórum público quanto nas três audiências públicas, e ainda realizaram revisões editoriais no intuito de analisar questões de correlação e consistência dos documentos.

O International Building Code está disponível para ser utilizado em situações locais específicas, pretendendo-se que o seu uso em um órgão governamental seja realizado de acordo com os procedimentos estabelecidos nas leis locais. 
Publicado em 2000, o International Building Code é mantido em constante atualização. As sugestões de alterações e propostas são analisadas e discutidas com os agentes participantes do processo. Ressalta-se, porém, que apesar das especificações e dos procedimentos que constam do IBC, teoricamente, assegurarem a qualidade e o desempenho dos edifícios, os membros participantes do desenvolvimento deste código não possuem nenhuma responsabilidade quanto ao cumprimento ou não de seu conteúdo. Somente o órgão governamental pode estabelecer que tal código seja lei, mediante sua autoridade.

Esse código estabelece parâmetros mínimos para os edifícios e seus subsistemas, utilizando disposições prescritivas e relacionadas ao desempenho. O documento é fundamentado em princípios que tornam possível o uso de novos materiais e novas técnicas de projetos. Além disso, o International Building Code foi concebido para ser compatível com toda a gama de "códigos internacionais" publicados pelo ICC.

Dentre os benefícios promovidos pelo IBC está o processo de desenvolvimento do model code, aqui traduzido como "código-modelo", o qual oferece um fórum internacional para que profissionais do setor da construção civil possam discutir desempenho e requisitos de códigos prescritivos. Este fórum proporciona um campo para o debate de revisões a serem propostas nos documentos e, além disso, esse processo também incentiva a cooperação internacional na aplicação das providências, tornando o código-modelo mais consistente.

Quanto ao seu conteúdo e estrutura, o IBC está subdividido em 35 capítulos e 10 anexos. Os capítulos tratam, dentre outros assuntos, de procedimentos administrativos; uso e ocupação do solo; requisitos de desempenho dos edifícios como resistência ao fogo, eficiência energética, segurança estrutural e conforto térmico; acessibilidade; especificações, materiais, procedimentos e requisitos de desempenho para fundação, estruturas de concreto, alvenarias, estruturas em aço e madeira, coberturas e telhados; requisitos gerais para o uso de vidro, gesso, plástico, etc. No último capítulo são citadas as normas de referência.

\subsubsection{Project Resource Manual-CSI Manual of Practices}

O prefácio desse documento faz uma breve introdução à história dos documentos técnicos empregados na construção civil. Como o presente capítulo tem por objetivo tratar do estado-da-arte dos referenciais tecnológicos, apresenta-se, sucintamente, a seguir, algumas informações a respeito dessa evolução dos documentos técnicos de referência, nos EUA. 
Assim, segundo o prefácio do manual aqui analisado, desde a era em que os primeiros povos começaram a construir estruturas para finalidades além de suas exigências pessoais, surgiu a necessidade de comunicar exatamente os desejos dos proprietários e dos "projetistas" àqueles profissionais que efetivamente executavam a construção. Tal comunicação foi se tornando cada vez mais complexa, à medida que a sociedade e a tecnologia se expandiram. Na época medieval, a arte da comunicação na construção civil evoluiu gradualmente, incluindo desenhos complementados por palavras escritas. No século XVII, surgiram os contratos escritos entre os reis e seus construtores, contendo: acordos, condições de contrato, projetos e especificações. No começo do século XX, o processo de produção do edifício, embora ainda relativamente simples e com poucos agentes envolvidos, passou a requerer descrições mais extensas para complementar os projetos da construção. Isto pode ser considerado o começo dos documentos de especificação, da forma como são conhecidos atualmente. $\mathrm{O}$ uso de especificações detalhadas aumentou durante a crise ocorrida nos anos de $1930 \mathrm{e}$ essa tendência continuou durante a Segunda Grande Guerra, período de expansão industrial nos EUA, no início dos anos 40 .

Em 1948, um grupo de pesquisadores norte-americanos organizou o Construction Specifications Institute (CSI) com a finalidade de melhorar as práticas da especificação na construção civil e indústrias afins. O CSI logo desenvolveu um método padrão para organizar as especificações de projeto, que se tornou a base do que, hoje, se considera um sistema de comunicação detalhado na construção civil nos EUA. Em 1961, o CSI publicou o seguinte documento: "A Tentative Proposal for a Manual of Practice for Specification Writing Methods". Este estudo conduziu à publicação do primeiro Manual of Practice, em 1967. Durante este mesmo período, o American Institute of Architects (AIA) adotou o título "Project Manual" em vez do então utilizado que citava a palavra "especificação". A finalidade era enfatizar que o livro das "especificações" continha mais do que o nome estava indicando e distinguia os documentos escritos dos desenhos. $\mathrm{O}$ uso do termo "Project Manual" e sua definição têm, desde então, ganho aceitação na indústria da construção civil norteamericana, como uma terminologia padrão e como um guia de conceito.

No início dos anos de 1960, o CSI e o Construction Specifications Canadá (CSC), trabalharam juntos no desenvolvimento, na publicação e na implementação dos padrões de 'práticas'. Essa parceria com o CSC continua a existir na forma de desenvolvimento e publicação conjunta de documentos técnicos e administrativos, resultando nas seguintes publicações: UniFormat ${ }^{\mathrm{TM}}$, MasterFormat ${ }^{\mathrm{TM}}$, SectionFormat $^{\mathrm{TM}}$ e PageFormat ${ }^{\mathrm{TM}}$.

O Manual of Practice (MOP) é reconhecido, atualmente, pela indústria da construção civil de toda a América do Norte, como sendo a base na qual os Manuais de Especificações e Projeto devem ser elaborados e implementados e, ainda, como os produtos devem ser apresentados à indústria da 
construção civil. Embora existam livros, artigos e softwares sofisticados nessa área, que podem auxiliar os usuários, projetistas, contratantes e representantes do setor, entre outros agentes envolvidos na construção civil, o MOP tornou-se uma fonte detalhada de informações, tanto na teoria quanto na prática, para o decorrer do ciclo de vida do edifício. A edição de 2004 foi renomeada como "The Project Resource Manual - CSI Manual of Practice (PRM)", indicando o seu caráter mais abrangente.

O CSI não é o único Instituto a formalizar seus padrões de 'práticas' em um guia de referência. Têmse, por exemplo, os seguintes manuais: Architect's Handbook of Professional Practice, do AIA; o Design-Build Manual of Practice, elaborado pelo Design-Build Institute of America (DBIA); e o Construction Estimating \& Bidding: Theory-Principles-Process, da Associated General Contractors of America (AGC). O PRM complementa estas publicações, identificando a importância das especificações aos agentes envolvidos na construção civil e servindo como base para a elaboração de documentos técnicos.

O PRM explicita o padrão do CSI para as 'praticas' de especificações da construção, além de complementar o documento The Uniform Drawing System ${ }^{\mathrm{TM}}$, contribuindo para a homogeneidade dos documentos das empresas de projeto e construção norte-americanas.

Além de o PRM ser a base preliminar para os programas de educação continuada e certificação profissional do CSI, é também um recurso útil para a área acadêmica, podendo ser utilizado como livro em cursos de tecnologia e gestão da construção. Pode ser usado ainda na área de administração de contratos e especificações.

O PRM foi concebido para ser uma ferramenta prática e acessível a todos os agentes envolvidos na cadeia produtiva da construção civil local, incluindo os proprietários (usuários) dos edifícios, arquitetos, engenheiros, projetistas, construtoras, empreendedores, gerenciadoras, representantes do setor, instituição financeira, etc, incentivando a troca de informação e conhecimento entre eles e promovendo a melhoria da comunicação, de técnicas e de procedimentos da construção.

A atual edição do PRM foi publicada em 2004 e corresponde à quinta revisão do MOP. As edições anteriores foram elaboradas de acordo com o formato (modelo) desenvolvido para os programas de educação e certificação do CSI. Já a atual apresenta as informações para cada estágio do ciclo de vida de um empreendimento, numa seqüência progressiva, desde seu planejamento e projeto, documentação, construção, até o uso e manutenção do mesmo. Esse novo formato evidenciou o caráter de interdependência entre os processos de produção dos edifícios, promovendo a necessidade de se ter o conceito de equipe para a obtenção do sucesso desse encadeamento. 
É importante notar que o PRM recomenda técnicas e uma filosofia para preparar, organizar, usar e interpretar documentos da construção civil, porém não contém as informações técnicas necessárias para desenvolver e produzir as especificações. Segundo o próprio documento, esse tipo de conhecimento técnico deve ser adquirido nas escolas ou na experiência profissional.

A atual edição foi revisada, expandida e reorganizada para identificar os interesses, as responsabilidades e as atividades de outros participantes do ciclo de vida dos empreendimentos, passando a incluir mais agentes da cadeia produtiva da construção civil e entidades que influenciam o ambiente construído. O novo formato do PRM está organizado de acordo com os seguintes módulos:

- módulo 1 - Introdução

- módulo 2 - Concepção do empreendimento

- módulo 3 - Liberação do empreendimento

- módulo 4 - Projeto

- módulo 5 - Documentos da construção

- módulo 6 - Orçamento / Negociação / Compra (Contratação)

- módulo 7 - Construção

- módulo 8 - Gerenciamento de facilidades

O objetivo do PRM é servir como um documento de referência que abrange uma ampla gama de informações necessárias para os profissionais envolvidos nos processos de projeto e construção de edifícios. Assim, parte-se do princípio que quanto melhor cada participante compreender os papéis e as responsabilidades dos outros participantes, melhor cada um poderá executar os seus próprios.

O PRM não pretende ser o único documento de referência para tais processos, e sim tem a intenção de complementar o material de referência já preparado por outras entidades, tais como o AIA, DBIA, AGC, e o Engineers Joint Contract Documents Committee (EJCDC).

\subsubsection{Building Code of Australia}

A primeira versão do Building Code of Australia (BCA), segundo Hunt (2005), foi elaborada em 1988, porém não foi aplicada em caráter nacional. Em 1990 foi publicada a primeira versão do documento que teve aplicação em todo o território australiano. A versão seguinte foi publicada em 1996, inserindo pela primeira vez os requisitos de desempenho exigidos para os edifícios. A versão mais recente do BCA data de 2005.

O Building Code of Australia é um documento detalhado, prescritivo, de requisitos e padrões técnicos para projeto e execução de edifícios e estruturas similares. É produzido e mantido pelo Australian 
Building Codes Board (ABCB). O BCA é aplicado em todo o território da Austrália, como um Código uniforme, porém, permite que sejam consideradas as variações climáticas, geológicas ou geográficas de cada região. Assim, a legislação relativa ao controle dos edifícios de cada Estado e Território adota o BCA, descrevendo tais diferenças e variações atribuídas ao documento, podendo excluir ou adicionar exigências.

O ABCB foi estabelecido em 1994, por meio de acordo entre a administração da Comunidade Britânica e cada governo de Estado e Território da Austrália. É constituído por representantes da Comunidade Britânica, de cada Estado e Território, do governo local e da indústria da construção civil. A missão do $\mathrm{ABCB}$ é desenvolver ações para que os edifícios, a nível nacional, tenham adequado desempenho, custos razoáveis e que atendam às necessidades da comunidade e da indústria do setor. O conselho técnico do $\mathrm{ABCB}$ é formado pelo Building Codes Committee (BCC), o qual é responsável pelos assuntos técnicos desenvolvidos no BCA.

O objetivo do documento Building Code of Australia é estabelecer os padrões mínimos aceitáveis de requisitos de desempenho dos edifícios, como segurança estrutural, segurança contra incêndio, bem como condições de saúde e conforto para a população da Austrália, trazendo benefícios a serem observados no presente e mantidos no futuro. Assim, o BCA deve ser de fácil entendimento, conter padrões que tenham um custo condizente com a realidade local, ter uma aplicação que não onere desnecessariamente a construção dos edifícios e abranger o necessário para o interesse público.

Segundo informações obtidas no artigo "What is the Building Code of Australia?" 25, cada Estado e Território da Austrália tem o poder de decidir quais requisitos e padrões técnicos, referentes ao edifício, que considera necessário. Entretanto, por ser desejável que todos os australianos tenham o mesmo nível de segurança e conforto nos edifícios, se fez interessante que tais Estados e Territórios cooperassem na elaboração de um código unificado de requisitos e padrões. Assim, o BCA é este código, fazendo com que o setor da construção civil utilize um único documento em toda a nação o que, conforme o artigo, é mais eficiente do que ter diversos códigos separados.

Quanto ao conteúdo do BCA, tem-se que tal documento é composto por dois volumes, sendo que um contempla os edifícios comerciais e públicos, e o outro as habitações e seus edifícios anexos. Cada volume possui requisitos de desempenho relacionados à segurança estrutural, à resistência ao fogo, à acessibilidade, à saúde e ao conforto, aplicáveis a cada tipo de edifício. O BCA abrange tópicos que incluem a capacidade de resistência das estruturas; requisitos de ventilação e iluminação; facilidade de acesso aos edifícios; recomendações para escadas, rampas e balaústres; para saídas de emergência;

\footnotetext{
${ }^{25}$ Artigo disponível em: <http://www.dhw.wa.gov.au/files/building_codes.pdf>. Acesso em: 3/1/2006.
} 
para área sanitária; para equipamentos de detecção de incêndio; e para sistemas de emergência e alarme. O BCA não cobre o aspecto visual dos edifícios, sua localização, nem outras questões de planejamento urbano.

É importante salientar que ambos os volumes do BCA foram desenvolvidos de modo a permitir flexibilidade para o uso de inovações tecnológicas, sejam produtos, projetos ou processos construtivos.

O BCA está estruturado de acordo com os seguintes itens:

- Objetivos: são indicações gerais de quais necessidades estão sendo contempladas pelos requisitos de desempenho. Este item é utilizado apenas como guia para auxiliar a interpretação do documento.

- Indicações funcionais: explicam como um edifício pode satisfazer às necessidades identificadas no item 'Objetivos' e também é usado somente como um guia para o BCA.

- Requisitos de desempenho: são as exigências com as quais o edifício deve estar de acordo, a fim de satisfazer aos regulamentos (Buildings Regulations). Os requisitos de desempenho visam a detalhar os níveis da segurança e conforto exigidos para os edifícios e partes específicas dos mesmos. Ressalta-se, entretanto, que os requisitos de desempenho apenas indicam os resultados a serem atingidos, mas não descrevem o processo de execução demandado para atendê-los. Desse modo, as exigências de desempenho permitem a utilização de tecnologias inovadoras, desde que sejam mantidas as condições de segurança e conforto do edifício.

- Prescrições consideradas satisfatórias: este item é também chamado de 'Construção aceitável' e tem o intuito de descrever uma solução, isto é, um meio para se atender às exigências de desempenho. Estas prescrições e recomendações facilitam o projeto e a aprovação de edifícios tradicionais, ou seja, nos quais a inovação não é o foco. Este item descreve as características a serem consideradas em um edifício, mas não fornece uma razão para tais. Entretanto, se uma construção estiver de acordo com as 'Prescrições julgadas satisfatórias', automaticamente também estará de acordo com os 'Requisitos de desempenho' relevantes. Neste item são contemplados, por exemplo, procedimentos para fundações, alvenarias, estruturas de aço e de madeira, revestimentos, telhados e coberturas.

Assim, um usuário do BCA deve escolher se prefere utilizar um processo já descrito no item 'Prescrições consideradas satisfatórias' ou se prefere adotar uma solução alternativa. Caso opte pela segunda opção, o responsável pela construção deve comprovar que a solução alternativa especificada satisfaz as exigências do item 'Requisitos de desempenho'. 
São feitas revisões e complementações regulares do BCA, visando ao aprimoramento do mesmo e à atualização de seu conteúdo devido ao avanço da tecnologia na construção civil local.

\subsubsection{National House-Building Council Standards}

O documento National House-Building Council Standards (NHBC-Standards) estabelece requisitos técnicos, padrões de desempenho e recomendações para projeto e execução de edifícios habitacionais aceitáveis pelo NHBC, no Reino Unido. Segundo informações obtidas no site do $\mathrm{NHBC}^{26}$, tal documento tem sido utilizado já há muitos anos. O documento disponível para análise no presente trabalho data de 1991, porém a publicação mais recente é de 2005. Os requisitos dispostos no documento são elaborados e revisados por um comitê que representa as principais organizações interessadas em promover melhorias na construção de edifícios. Em tal comitê têm-se construtores, organizações representativas dos consumidores e entidades profissionais.

Os padrões estipulados no NHBC-Standards estão de acordo com os Regulamentos do Edifício (Building Regulations) e com as Normas Britânicas (British Standards). Além disso, têm como base os próprios registros do NHBC de patologias e defeitos encontrados em edifícios habitacionais, tentando especificar ações preventivas para minimizar tais problemas.

Durante a construção dos edifícios, os inspetores do NHBC realizam vistorias nas obras, durante as principais etapas do processo de produção, para se certificarem, de forma prática, que o construtor está executando a obra de acordo com os padrões estabelecidos no NHBC-Standards e se os riscos são aceitáveis no âmbito do Buildmark ${ }^{27}$. Entretanto, o inspetor do NHBC não verifica cada detalhe da construção em cada propriedade, uma vez que a responsabilidade de construir conforme os padrões do NHBC e os Regulamentos do edifício é do próprio construtor.

Uma das maneiras do NHBC continuar promovendo a melhoria da qualidade dos novos edifícios e casas é realizando a revisão e o aprimoramento contínuo de seus requisitos técnicos. Assim, em 2003, o NHBC-Standards foi submetido a uma ampla revisão de diversos capítulos, tendo-se ainda introduzido uma série de modificações para realinhar tal documento com as mudanças realizadas nos Regulamentos dos Edifícios e nas Normas Britânicas e Européias. Em 2005, foram adicionados dois

\footnotetext{
${ }^{26}$ Disponível em: <http://www.nhbc.co.uk/Newscentre/Library/filedownload,16299,en.pdf>. Acesso em: 3/1/2006.

${ }^{27}$ O Buildmark é um acordo entre o construtor, o NHBC e cada comprador das edificações, funcionando como um segurogarantia. Na primeira parte do livro do Buildmark são especificados os direitos e as obrigações dos construtores e do NHBC. Os construtores devem seguir as recomendações do NHBC-Standards; e o NHBC fornece um seguro-garantia de desempenho durante a execução da obra, nos dois primeiros anos depois da construção e do terceiro ao décimo ano do edifício, sob determinadas condições específicas. Na segunda parte do livro apresenta-se um Guia do Usuário para os compradores dessas habitações (NHBC, 1990).
} 
novos capítulos, contemplando as seguintes inovações tecnológicas: as fachadas-cortina e as estruturas metálicas leves - light steel frame.

Além de trabalhar para melhorar a especificação de seus próprios padrões, o NHBC contribui de forma significativa para o setor da construção civil no Reino Unido. Estabelecido há quase 70 anos, o NHBC é um órgão responsável por fornecer garantia e seguro para novos edifícios habitacionais no Reino Unido. Como uma companhia sem fins lucrativos, sua finalidade primeira é implementar requisitos e padrões técnicos na construção, bem como fornecer a 'defesa do consumidor' para os proprietários de novas casas e edifícios. Isto é feito por meio do registro dos construtores. Mais de 18.000 construtores de casas, que constroem aproximadamente $85 \%$ das novas casas construídas a cada ano no Reino Unido, são registrados no NHBC. Os construtores que se candidatam ao registro passam por uma avaliação técnica e financeira, podendo ser rejeitados. O não comprimento do NHBC-Standards conduz à uma investigação que pode levar ao cancelamento do registro do construtor.

O NHBC fornece garantia e seguro que os construtores podem passar aos compradores dos edifícios. Por exemplo, por 10 anos, a garantia e o seguro do Buildmark protegem os proprietários de novas casas contra defeitos específicos que resultam da construção não-conforme com o NHBC-Standards.

O NHBC considera o feed-back das sugestões de profissionais do setor da construção civil e as informações fornecidas pelos proprietários dos edifícios, visando a retroalimentação de seu conteúdo.

Quanto à estrutura e conteúdo do NHBC-Standards, tem-se, em sua edição de 1991, que tal documento é apresentado em dois volumes, sendo cada volume dividido em 5 partes, as quais são ainda subdivididas em um ou mais capítulos. As partes desse documento seguem as etapas usuais do processo de produção de um edifício. Os capítulos, em geral, são estruturados em seções que citam informações sobre projeto, materiais e execução de cada parte. Em alguns casos, pode ser que um ou mais desses aspectos não seja(m) incluso(s). As informações gerais sobre os requisitos e padrões técnicos encontram-se no primeiro volume. Além disso, tal volume contempla requisitos técnicos e recomendações para alguns materiais, para os serviços preliminares de execução da obra, para as etapas de fundação, contenção e infra-estrutura. Já o segundo volume aborda os requisitos técnicos e recomendações para a execução da estrutura propriamente dita (incluindo paredes internas e a fachada), dos telhados e coberturas, dos revestimentos e acabamentos, dos serviços externos (como garagens, calçadas, etc.) e serviços complementares.

Os padrões especificados no NHBC-Standards são efetivamente válidos para todos os construtores registrados no NHBC que tiveram sua adesão durante ou após a publicação dos mesmos. Cada capítulo mostra a data de vigência de seus requisitos, sendo estes aplicáveis a todo o Reino Unido, a menos que se indiquem exceções. 
O NHBC-Standards apresenta três tipos de dados, os quais, no intuito de facilitar o entendimento do documento são escritos em diferentes cores (respectivamente: vermelho, azul escuro e azul claro). São eles:

- requisitos técnicos;

- padrões de desempenho; e

- recomendações.

Quanto aos requisitos técnicos, cada capítulo contém os cinco mandamentos relativos a estes, que devem ser cumpridos pelo construtor. São apresentados os seguintes: requisitos legais, os quais incluem, por exemplo, assuntos relacionados à saúde e segurança do edifício, assuntos estes que não são abordados pelo NHBC-Standards; requisitos de projeto e especificações que visam ao adequado desempenho do edifício; requisitos de materiais, produtos e componentes ${ }^{28}$ que devem ser adequados para o seu respectivo uso; requisitos relacionados à mão-de-obra para que toda a obra seja executada de maneira apropriada; e, por fim, os requisitos do projeto estrutural, o qual deve ser realizado por profissionais qualificados e deve atender às normas britânicas e códigos de práticas (Codes of Practices).

Padrões de desempenho alternativos somente são aceitos se o NHBC considerar que estes não são inferiores aos especificados em seu documento e que os requisitos técnicos são compatíveis com os seus.

Em relação às recomendações do NHBC-Standards, estas são baseadas em procedimentos tradicionais e orientações práticas que demonstraram, pela experiência de execução, que são satisfatórias e aceitáveis. O NHBC considera métodos alternativos mediante consulta e análise prévia.

Percebe-se, após a apresentação desse item, que os Codes of Practices são, essencialmente, uma expressão do setor da construção civil de países anglo-saxões (EUA, Inglaterra, Austrália; ver também Tabela 6).

Tem-se, ainda, como um importante referencial tecnológico estrangeiro, o Document Technique Unifié, aqui traduzido como Sistema de Documentos Técnicos Unificados (DTU), utilizado na França. Tal documento é analisado mais detalhadamente, como objeto do estudo exploratório, no Capítulo 4.

\footnotetext{
${ }^{28} \mathrm{O}$ NHBC, quando achar necessário, pode solicitar ao construtor que realize ensaios em amostras de determinados materiais, produtos ou componentes, visando atestar que os mesmos estão de acordo com o especificado no NHBCStandards. O custo do ensaio deve ser pago pelo construtor se o resultado for não-conforme, ou pelo NHBC se o resultado for conforme.
} 
Por outro lado, muitos países ainda precisam desenvolver referenciais desse tipo. Por exemplo, em Portugal, segundo Henriques (2001), a situação da qualidade dos edifícios ainda pode ser caracterizada como insuficiente; e, portanto, como um fator indutor de melhorias nesse setor, o autor ressalta que é "particularmente importante desenvolver em Portugal documentos do tipo 'Code of Practice' ou 'DTU', nos quais são incluídos as pormenorizações e tipologias mais significativas das tecnologias de construção correntes, possibilitando a existência de referências que podem ser utilizadas com segurança pelos intervenientes no processo construtivo".

O Brasil também não têm os documentos do tipo 'Code of Practice' ou 'DTU'. Entretanto, algumas experiências nacionais com documentação técnica de referência são apresentadas no item a seguir.

\subsection{Experiências Nacionais}

Em relação às experiências nacionais, são identificados e analisados alguns documentos técnicos de referência para a construção de edifícios no Brasil, que contribuam para auxiliar na melhoria da qualidade e do desempenho das edificações, ou disseminar o conhecimento, estabelecendo especificações, procedimentos e exigências para as determinadas etapas do processo de produção das mesmas.

A origem dos documentos é diversa, podendo ser obra de autor ou originária de órgão público, por exemplo, de diferentes localidades do país.

A análise de cada um dos documentos está estruturada de acordo com os seguintes itens: responsável pela elaboração do documento, data de publicação, natureza e tipo do documento, origem e objetivo, público-alvo, estrutura e conteúdo. Caso haja detalhes importantes ou particularidades que mereçam uma especial atenção, são feitos comentários gerais no decorrer dos itens.

Assim, são aqui apresentados alguns documentos técnicos selecionados segundo os conceitos e critérios abordados no item 1.5 , relativo à metodologia de desenvolvimento dessa pesquisa. Procurouse adotar a ordem cronológica de apresentação, tomando como referência a primeira edição dos documentos. Embora procure se citar a data da última edição dos mesmos, a pesquisa feita, consideradas as limitações da obtenção de alguns dados e o escopo do trabalho, não torna possível assegurar a precisão absoluta dessa informação, entendendo-se que se houver engano, nesse caso, não haverá prejuízo maior para o atendimento do objetivo do item. 


\subsubsection{Caderno de Encargos - Eng ${ }^{o}$ Paulo Costa}

Responsável: engenheiro civil Paulo Costa.

Data de publicação: em 1939 foi publicada a primeira edição. Posteriormente, Paulo Costa publicou outras edições, revisadas e atualizadas. A mais recente é a $8^{a}$ edição, datada de 1962, publicada pela Editora Científica, no Estado do Rio de Janeiro.

Natureza e Tipo do documento: este documento apresenta-se sob a forma de livro, com o título "Caderno de Encargos para a Construção de Edifícios". Ressalta-se, aqui, que os cadernos de encargos são voltados, fundamentalmente, para a especificação do produto, ou seja, no caso o edifício, ainda que este documento aborde uma descrição sucinta de execução da obra. Portanto, quanto ao tipo do documento, observa-se que é um referencial tecnológico referente à especificação do produto, incluindo uma pequena parte de procedimentos de execução, e não trata do controle do processo.

Origem e Objetivo: este trabalho é fruto da organização de anotações feitas ao longo de anos de prática pessoal do autor, de construir edifícios, com a colaboração de seus colegas de trabalho, sendo talvez o primeiro livro nacional com esse escopo. Segundo o próprio autor, a sua observação constante dos serviços técnicos da construção de edifícios mostrou-lhe a necessidade de "fixar normas técnicas gerais com o fim de reduzir a um mínimo as questões possíveis de controvérsia criando, assim, um melhor e mais claro entendimento entre os interessados".

Público-alvo: profissionais do setor da construção de edifícios, arquitetos, engenheiros, etc. Por se tratar de um caderno de encargos, este documento é, basicamente, o resultado que o contratante de uma obra desejaria obter.

Estrutura e Conteúdo: a $1^{\mathrm{a}}$ edição deste Caderno de Encargos é subdividida em três partes:

- Parte 1: Especificações técnicas

- Parte 2: Unidades compostas

- Parte 3: Tabelas e instruções

A parte de interesse para o presente estudo é a primeira, sendo que a segunda traz elementos relativos aos preços de materiais, mão-de-obra, etc. e a terceira parte trata-se de tabelas, gráficos e instruções geralmente necessários, evitando a busca em outros livros ou manuais.

O conteúdo da Parte 1 é subdividido em itens numerados seqüencialmente que tratam desde a preparação do terreno e execução das fundações até revestimentos e acabamentos. Inclui também itens relativos à medição das obras e indicações para o cálculo de estruturas de concreto armado. Não existe uma estrutura padronizada de apresentação de cada item referente aos serviços de execução de obras. 
Não são citadas normas estrangeiras de referência, as quais seriam as únicas existentes até aquele momento, uma vez que a ABNT, que é o órgão responsável pela normalização técnica no país, foi fundada apenas em 1940.

Já a edição mais recente do livro ( $8^{\mathrm{a}}$ edição), por sua vez, é composta por cinco partes: a primeira parte aborda a construção de edifícios quanto aos aspectos administrativos, bem como as especificações técnicas da obra. São abrangidos os principais serviços de execução desde os trabalhos preparatórios para o início da obra, passando pela fundação, estrutura, revestimento até coberturas e serviços complementares. Ao final da primeira parte são citados, ainda, alguns materiais a serem utilizados. A segunda parte do Caderno trata dos custos da obra e organização de orçamentos. As partes restantes são relacionadas ao detalhamento de alguns serviços específicos, como por exemplo, os voltados aos problemas urbanos como água, esgoto e transportes.

Este documento apresenta-se bastante complexo, de difícil entendimento e leitura, sem lógica aparente de apresentação, os itens relacionados a cada serviço não possuem uma estrutura bem definida e padronizada entre eles. Envolve composições de custos e quantificações de materiais, podendo ser utilizado como apoio para execução de obras, uma vez que abrange tanto a parte técnica como a financeira (orçamentação).

\subsubsection{Caderno de Encargos do Governo do Estado do Rio de Janeiro}

Responsável: elaborado pelo Departamento de Engenharia da Secretaria de Obras do Governo do Estado do Rio de Janeiro.

Data de publicação: primeira edição em março de 1971, porém não foi obtida informação sobre a última edição.

Natureza e Tipo do documento: este documento, intitulado "Caderno de Encargos", foi uma publicação da Editora Diálogo Ltda. em Niterói, no Rio de Janeiro. São citados referenciais tecnológicos para especificação do edifício, bem como procedimentos de execução da obra.

Origem e Objetivo: segundo descrito no Prefácio do próprio "Caderno de Encargos", este representa uma tentativa de homogeneização dos serviços relativos à construção de edifícios públicos pelo Departamento de Engenharia da Secretaria de Obras do Governo do Estado do Rio de Janeiro, apresentando normas de execução de serviços, aspectos referentes à qualidade e aplicação de materiais, dentre outros. 
Público-alvo: agentes do setor da construção civil envolvidos na contratação de obras públicas no Estado do Rio de Janeiro, uma vez que o documento cita especificações e procedimentos exigidos pelo contratante e que devem ser cumpridos pelo contratado.

Estrutura e Conteúdo: este caderno de encargos é subdividido em três partes:

- Parte I - Planejamento da obra

- Parte II - Materiais a empregar

- $\quad$ Parte III - Execução da obra

Em relação à parte de execução da obra, são tratados aspectos administrativos (licitação, contrato, etc.) e aspectos técnicos como por exemplo: movimentos de terra, fundação, estrutura (concreto e alvenaria), cobertura, esquadrias, instalações hidráulica, de esgoto, elétrica, de águas pluviais, revestimentos, pavimentação, pintura, impermeabilização, dentre outros.

Cada item relativo a um serviço de execução da obra da Parte III, em geral, apresenta os seguintes subitens: 'Condições Gerais', nas quais são citadas algumas referências técnicas, por exemplo normas caso existam; 'Normas Gerais' para explicitar os cuidados e procedimentos a serem seguidos, os quais são organizados em alíneas; e, caso necessário, são incorporados subitens relativos às atividades específicas a cada serviço.

\subsubsection{Manual Técnico do DOP - Governo do Estado de São Paulo}

Responsável: este documento estava inserido no âmbito do extinto Departamento de Edifícios e Obras Públicas (DOP) do Governo do Estado de São Paulo, o qual foi uma autarquia que funcionou por 150 anos seguidos e ajudou a executar diversas obras públicas do Estado, tendo sido extinto no final da década de $80^{29}$. Em 1991, a partir do antigo DOP, foi criada a Companhia Paulista de Obras e Serviços $(\mathrm{CPOS})^{30}$, pela Lei Estadual $\mathrm{n}^{\mathrm{o}} 7394$ de 8/7/91, com a finalidade de administrar, planejar, projetar, construir, reformar, conservar e ampliar os edifícios de propriedade do Governo do Estado de São Paulo ou de entidades sob seu controle. Trata-se de uma empresa de economia mista, na qual o Estado é o principal acionista, responsável pela prestação de serviços de engenharia ou de consultoria às diversas entidades do Estado, sendo, atualmente, vinculada à Secretaria de Energia, Recursos Hídricos e Saneamento.

\footnotetext{
${ }^{29}$ Informações obtidas na Revista ENGENHARIA - edição 539. Artigo: CPOS, o braço técnico nas obras públicas. 2000. Disponível em: <http://www.brasilengenharia.com.br/ed539.htm>. Último acesso: 1/7/2005.

${ }^{30}$ Informações disponíveis em:<http://www.cpos.com.br>. Último acesso: 1/7/2005.
} 
Data de publicação: a primeira versão data de 1972. Posteriormente, foram lançadas algumas edições que dizem respeito apenas à terceira parte (Parte C) do Manual Técnico do DOP, denominada "Caderno de Encargos", a qual é de maior interesse para o presente estudo. Estes documentos foram intitulados "Caderno de Encargos de Edificações - Manual Técnico do DOP, Tomo III", tendo sido publicada a $3^{\text {a }}$ edição no ano de 1976.

Natureza e Tipo do documento: está sendo analisada, neste item, somente a parte relativa ao "Caderno de Encargos" do Manual Técnico do DOP. Trata-se de referenciais tecnológicos para especificação do produto, incluindo especificações gerais de cada serviço (exigências quanto aos procedimentos de execução) e critérios de medição.

Origem e Objetivo: segundo os próprios autores do Manual, o objetivo deste documento é auxiliar no relacionamento entre contratante (DOP) e contratado (empresa construtora), sem interferir em questões administrativas, mas sim fornecendo elementos técnicos úteis. Ou seja, objetiva estabelecer as condições técnicas (normas, especificações e coeficientes para composições de preços) referentes à execução de obras e serviços e fixar as obrigações e direitos do DOP e da construtora.

Público-alvo: agentes do setor da construção civil envolvidos na contratação de edifícios e obras públicas no Estado de São Paulo. O documento cita especificações e procedimentos exigidos pelo contratante e que devem ser cumpridos pelo contratado, incluindo a parte técnica e orçamentária (coeficientes para composições de preços).

Estrutura e Conteúdo: o Manual Técnico, em sua primeira edição, era constituído por seis partes, subdivididas em capítulos, conforme visto a seguir:

- Parte A: Generalidades do Manual Técnico

- Parte B: Projetos

- Parte C: Caderno de Encargos

- Capítulo I: Generalidades

- Capítulo II: Especificações de Serviços e Critérios de Medição

- Capítulo III: Especificações de Materiais

- Capítulo IV: Coeficientes para Composições de Preços

- Parte D: PERT/CPM e Cronogramas Físico-financeiros

- Parte E: Normas Gerais de Fiscalização ${ }^{31}$

- Parte F: Obras de Arte

\footnotetext{
${ }^{31}$ Nota-se que o termo "fiscalização", adotado na época, é hoje entendido e denominado como "controle". Portanto, no decorrer do texto, quando pertinente, essa substituição de termos é feita por parte da autora do presente trabalho. Algumas vezes, o termo original foi mantido.
} 
Segundo informações constantes do próprio Manual, na parte relativa a 'Projetos' tem-se uma caracterização dos elementos mínimos necessários à elaboração e apresentação de projetos completos, bem como a integração entre suas partes constituintes: arquitetura, estruturas e instalações. Já no que se refere à parte de 'Caderno de Encargos', o autor ressalta que as "normas gerais” das especificações de serviços foram expostas com o objetivo de "estabelecer as condições mínimas exigíveis para a correta execução de cada serviço". No Capítulo II, dessa parte, o qual tem particular interesse para o presente estudo, são abordados os seguintes serviços: serviços preliminares; movimento de terra; sondagens e fundações; concreto armado; alvenaria de elevação; instalações elétricas; instalações hidráulico-sanitárias; impermeabilizações; cobertura; esquadrias de madeiras; esquadrias metálicas; revestimentos; pisos, rodapés, soleiras e peitoris; vidros, serviços complementares; pintura; aparelhos sanitários e elétricos; limpeza e equipamentos e outras instalações.

A $3^{\circ}$ edição desse Manual Técnico, de 1976, particularmente a que aborda somente o Caderno de Encargos, é constituída por 6 capítulos, abrangendo os seguintes assuntos:

- Generalidades;

- Especificações de materiais;

- Especificações de serviços, coeficientes para composições de preços e critérios de medição para demolições ou retiradas;

- Especificações de serviços, coeficientes para composições de preços e critérios de medição para edificações;

- Especificações de serviços, coeficientes para composições de preços e critérios de medição para conservação;

- Roteiro para a fiscalização.

\subsubsection{Caderno de Encargos - Editora PINI}

Responsável: elaborado pelo engenheiro Milber Fernandes Guedes.

Data de publicação: a $1^{\mathrm{a}}$ edição desse documento foi publicada em 1982, pela Editora PINI. A última versão, atualizada e revisada, é a $4^{\text {a }}$ edição, publicada em fevereiro de 2004 pela mesma Editora.

Natureza e Tipo do documento: trata-se de um livro técnico, intitulado "Caderno de Encargos", o qual é definido pelo próprio autor como "um conjunto de especificações, critérios, condições e 
procedimentos estabelecidos pelo proprietário ${ }^{32}$ para a contratação, execução, fiscalização e controle de obras ou serviços". Portanto, quanto ao tipo do documento, pode-se dizer que são englobados referenciais tecnológicos para especificação do produto, para procedimentos de execução e para controle do processo de produção de edifícios.

Origem e Objetivo: na primeira edição desse documento, o autor cita que o intuito de seu livro é "suprir uma falha na biblioteca de quem projeta, constrói e fiscaliza obras". Na quarta edição, o autor explica o porquê da denominação 'Caderno de Encargos'. Afirma que tal expressão, do francês 'Cahier de Charges', exprime com precisão o espírito do seu livro publicado, uma vez que a palavra 'Caderno' é entendida como significando reunião de folhas, e a palavra 'Encargos' como traduzindo que o texto, impresso nessas folhas, reúne as obrigações do construtor, no que se refere às especificações e aos procedimentos, conforme definição da $\mathrm{ABNT}^{33}$, bem como outras de caráter administrativo, tais como: regime de construção, responsabilidade e garantia, licenças e franquias, seguros e acidentes, recursos e arbitragens, ordens de serviço, assistência técnica e administrativa, recebimento das obras etc. Portanto, a finalidade desse Caderno de Encargos, segundo Guedes (2004), é "além de completar informações de projetos, ser um elemento fundamental para homogeneizar propostas e, em decorrência, facilitar o julgamento das ocorrências".

O Caderno de Encargos, ainda segundo o autor, pretende desempenhar a função de uma minibiblioteca, pois representa um conjunto de definições, dados e normas dispersos em publicações, catálogos e livros nem sempre acessíveis. Por fim, o Caderno de Encargos se propõe a "esclarecer e definir determinados assuntos ligados à construção, os quais, por motivos diversos, permanecem com a sua conceituação indefinida para engenheiros e arquitetos".

Público-alvo: pode ser utilizado por contratantes e contratados para executar construções de edifícios, tendo, segundo o próprio documento, as seguintes funções: servir como guia dos proponentes, permitindo a elaboração de um orçamento correto; ser um documento contratual, esclarecendo e limitando responsabilidades do proprietário e do construtor; e apresentar diretrizes dos serviços e obras, orientando fabricação, escolha, aquisição, utilização ou aplicação de materiais, equipamentos e sistemas. Pode ser lido também por profissionais, pesquisadores ou estudantes de engenharia civil ou arquitetura, como complementação às informações técnicas curriculares.

\footnotetext{
${ }^{32}$ Entende-se por proprietário, segundo o autor, "o contratante das obras". Guedes (2004) ainda cita a definição encontrada na NBR 5671:1990: "pessoa física ou jurídica de direito, que tem a capacidade de determinar a execução de um empreendimento, correndo por sua conta todas as despesas inerentes". Cita ainda que, em se tratando de edifícios públicos, o proprietário é o "órgão que contrata a execução de serviços e obras de construção, complementação, reforma ou ampliação de uma edificação ou conjunto de edificações."

33 A Associação Brasileira de Normas Técnicas reservou o termo "Especificação" para os documentos destinados à caracterização de materiais, elementos de construção e equipamentos, e o título "Procedimento" para prescrever condições de cálculo ou de execução de serviços (GUEDES, 2004).
} 
Estrutura e Conteúdo: quanto à divisão temática desse documento, tem-se que o mesmo está estruturado em três partes, conforme apresentado a seguir:

- Primeira parte - Generalidades: agrupamento de normas contendo condições gerais não tratadas no Edital ou Instruções de Concorrência e no Contrato, bem como outras indicações do mesmo gênero. Essa parte está subdividida em títulos, adotando-se o critério de classificação por ordem cronológica dos eventos ao longo de uma obra.

- Segunda parte - Materiais e Equipamentos: compreende características básicas para todos os materiais e equipamentos de emprego previsível na obra considerada. Tal parte está subdividida em títulos, segundo o critério de classificação por ordem alfabética.

- Terceira parte - Procedimentos: abrange as condições de execução de cada tipo de serviço. Essa parte está subdividida em capítulos, abordando: serviços preliminares; implantação e administração; movimento de terra e serviços correlatos; fundação; estrutura; alvenaria e outras vedações; cobertura; impermeabilização; tratamento térmico e acústico; pavimentação; revestimento; divisórias, forros e pisos falsos; carpintaria e marcenaria; serralharia; ferragens; vidraçaria; pintura; enceramento, lustração e vitrificação; instalação elétrica e de telecomunicações; instalação de água; instalação contra incêndio; instalações sanitárias de esgotos e águas pluviais; instalações especiais; instalação de gás; instalação de transporte vertical; instalação de condicionamento de ar e de ventilação mecânica; lixo; equipamento sanitário e de cozinha; limpeza e verificação final; paisagismo, urbanização e decoração.

Segundo o autor, há a possibilidade de existir uma Quarta parte como complemento do Caderno de Encargos, específica para cada obra. Esta parte, denominada 'Especificações de Serviços' pode conter indicações dos locais de aplicação de cada um dos tipos de serviços, acompanhadas pela caracterização de produtos pela marca, bem como definições precisas dos tipos de sistemas a serem empregados na obra que se está especificando.

\subsubsection{PROCONTROL $-I P T / B N H$}

Responsável: trata-se de algumas ações desenvolvidas no âmbito do Programa de Controle de Qualidade das Construções Habitacionais (PROCONTROL), elaboradas pelo IPT, conforme solicitação do BNH.

Data de publicação: as ações citadas ocorreram entre os anos de 1981 a 1982, sendo que o Relatório Final elaborado pelo IPT é de janeiro de 1983. 
Natureza e Tipo dos documentos: estes documentos são relatórios técnicos emitidos pelo IPT para o BNH. Em particular, de interesse para o presente estudo, têm-se os seguintes tipos de documentos técnicos de referência elaborados pelo Programa: de especificação e procedimentos de execução de serviços, de fiscalização e controle da execução. Assim, quanto ao tipo dos documentos, verifica-se a abrangência no que diz respeito aos três gêneros citados na Tabela 5: referenciais tecnológicos de especificação de produto, de procedimentos de execução e de controle de processo.

Origem e Objetivo: o PROCONTROL visa explicitamente desenvolver documentos técnicos para orientar as atividades de projeto e construção, bem como a avaliação de seus resultados.

Para a elaboração de tais documentos técnicos, de acordo com o IPT (1983) foram realizadas consultas a diversos especialistas e aplicação piloto dos documentos em edificações em fase de execução. Analisaram-se, também, as normas técnicas vigentes na época, fundamentalmente constituída por textos normativos da ABNT. Ainda segundo IPT (1983), para a concretização desses documentos, foram selecionadas obras que utilizavam sistema construtivo tradicional e aplicados os documentos, previamente elaborados, de alvenaria estrutural de blocos de concreto, revestimentos em argamassa, coberturas e estruturas de coberturas, instalações hidráulicas e elétricas. Desse modo, as visitas efetuadas propiciaram uma visão dos tipos de problemas que ocorriam e podiam ocorrer nos serviços de execução e que podiam estar relacionados com a falta de documentos técnicos para execução, fiscalização ou recebimento, levando ao aprimoramento dos textos previamente elaborados. Quanto às consultas aos profissionais, estas foram feitas com o envio dos documentos técnicos a um conjunto de especialistas, estabelecendo-se como critério de seleção os profissionais que trabalhavam com projeto, execução, fiscalização e fabricação de materiais e componentes constituintes de cada serviço. As contribuições do meio técnico foram analisadas e, quando julgadas pertinentes, foram incorporadas aos respectivos documentos.

Em relação à normalização técnica, o IPT (1983) constatou na época que a disponibilidade de textos normativos para cada serviço definido era heterogênea, surgindo, portanto, a preocupação em obter um sistema homogêneo de informações para os elementos da edificação.

Público-alvo: os documentos foram elaborados por pesquisadores para auxiliar na especificação, na execução e no controle de obras voltadas à habitação de interesse social financiadas pelo BNH. Portanto, podiam ser utilizados pelas construtoras em geral e exigidos pelo contratante das obras. A princípio, os documentos técnicos contemplavam edificações térreas unifamiliares e multifamiliares de até quatro pavimentos, construídas segundo processos convencionais. 
Estrutura e Conteúdo: segundo IPT (1981b), a estruturação dos documentos técnicos aplicáveis ao sistema de controle é tal que permite a constituição de um referencial consistente e completo para as etapas do processo construtivo envolvidas em cada elemento da edificação. Por consistente, entende-se uma coerência do "referencial técnico ${ }^{34}$, no sentido de se obter respostas unívocas para os problemas específicos que se apresentam nas diversas fases do processo. Assim, tem-se que: "uma dada recomendação de projeto deverá encontrar rebatimento coerente nas atividades relativas à execução e fiscalização do mesmo item, de maneira que as recomendações inerentes aos diferentes momentos do processo não levem à adoção de soluções conflitantes entre si com respeito ao objeto considerado".

A consistência do referencial técnico, de acordo com o IPT (1981b), deve ser em parte assegurada pela correta estruturação dos principais documentos técnicos relativos aos elementos da edificação. Assim, por meio de uma 'unificação' dos itens fundamentais com base na hierarquia definida no PROCONTROL, "procurou-se criar condições para que um determinado elemento ou parte fundamental deste fosse facilmente analisável quanto a aspectos de conteúdo inerente às diversas etapas do processo construtivo como um todo".

Os principais serviços de execução da edificação, observando-se as respectivas fases de execução da obra, são objeto de documentos técnicos organizados a partir dos seguintes tipos de textos normativos:

- procedimentos para a apresentação de projetos;

- $\quad$ procedimentos de concepção;

- procedimentos de execução;

- procedimentos de fiscalização (qualitativa);

- procedimentos de programação;

- procedimentos de orçamentação;

- procedimentos de medição; e

- especificações.

Tendo em vista promover a consistência do sistema, os diversos documentos são estruturados de maneira unificada para cada elemento considerado, sendo a definição dos itens específicos uma característica do tipo de documento (IPT, 1981b). A articulação das informações pode ser vista na Figura 8, a seguir.

\footnotetext{
${ }^{34}$ Denominação adotada no Relatório Técnico emitido pelo IPT ao BNH (IPT, 1981b).
} 


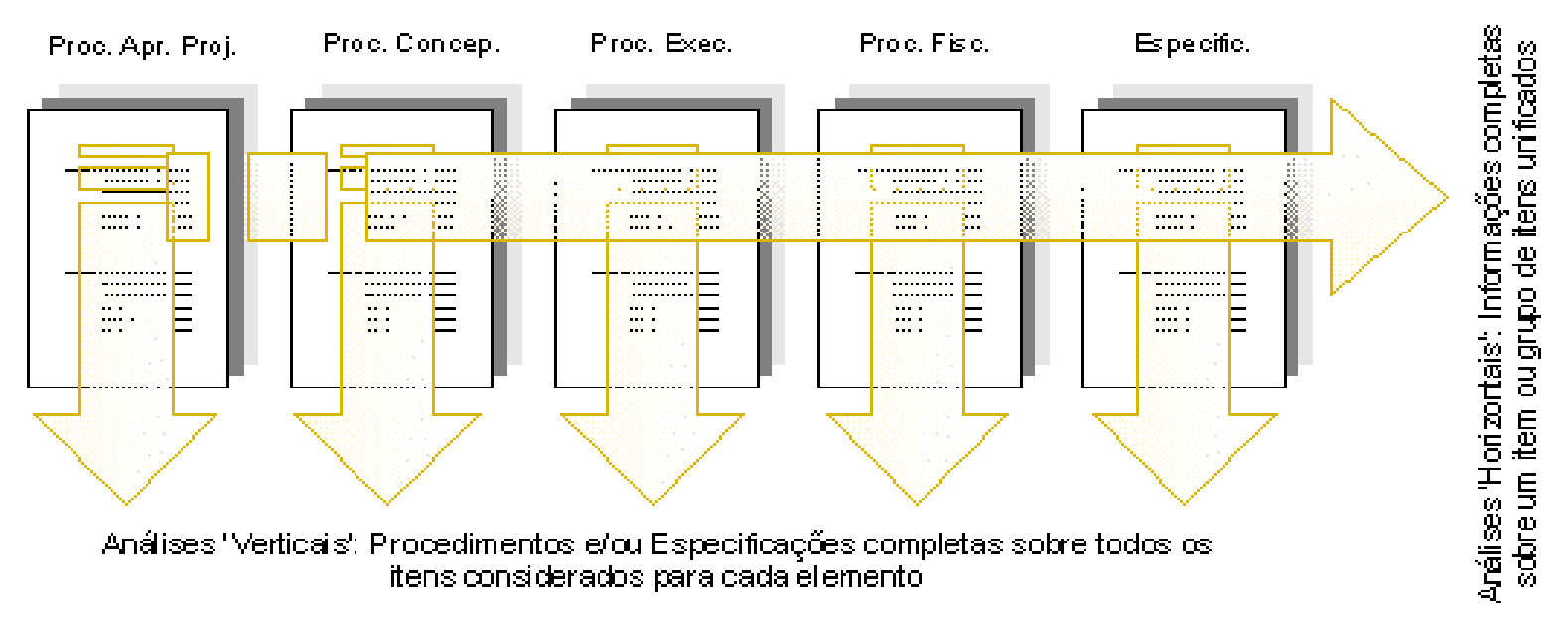

Figura 8 - Esquema de articulação das informações nos documentos técnicos propostos no PROCONTROL. (Fonte: IPT, 1981b)

Conforme visto na Figura 8, a consulta aos documentos técnicos elaborados pelo IPT é feita de maneira diferenciada para cada atividade envolvida no processo. As áreas técnicas responsáveis pelo projeto, execução e fiscalização tendem a utilizar os documentos na 'vertical', enquanto os responsáveis pelo controle global do processo fazem constantes recuperações por item independente, na 'horizontal'.

A estruturação dos procedimentos de concepção, execução e fiscalização, conforme o IPT (1981b), é basicamente a seguinte:

- 1 . Objetivo

- 2. Normas e documentos complementares

- 3. Definições

- 4. Condições Gerais

- 5. Condições Específicas

- 6. Inspeção*

- 7. Aceitação e Rejeição*

- ANEXOS

(*) Apenas para os procedimentos de fiscalização.

Os procedimentos contêm recomendações relativas às atividades envolvidas nos processos de concepção e execução dos elementos, bem como critérios para a fiscalização de obras quanto aos aspectos qualitativos. Entretanto, de acordo com IPT (1982), os procedimentos de concepção relativos aos diversos elementos da edificação são desmembrados dos procedimentos de execução e fiscalização, visando tornar mais simples a consulta, já que o primeiro refere-se, principalmente, aos projetistas enquanto os outros são voltados, predominantemente, ao "pessoal de obra". 
Segundo IPT (1983), foram contemplados os seguintes serviços de execução: fundações, estruturas de concreto armado, alvenarias sem função estrutural (blocos cerâmicos furados, tijolos maciços de barro cozido e blocos vazados de concreto), telhados (telhas cerâmicas e telhas onduladas de cimentoamianto), estruturas de madeira para telhados, instalações prediais (água fria, esgoto, águas pluviais, combate à incêndio e instalações elétricas), pisos cerâmicos, pisos cimentados e revestimentos para paredes e tetos (argamassas e pinturas).

Resumidamente, a abrangência dos documentos técnicos do PROCONTROL e os tipos de documentos estudados estão apresentados na Tabela 7.

Tabela 7 - Tipo e abrangência dos documentos técnicos do PROCONTROL. (Fonte: IPT, 1981a)

\begin{tabular}{c|c|c}
\hline \multirow{2}{*}{$\begin{array}{c}\text { Tipos dos Documentos } \\
\text { Técnicos }\end{array}$} & \multicolumn{2}{|c}{ Abrangência dos Documentos Técnicos } \\
\cline { 2 - 3 } & \multicolumn{1}{c}{ Atividades } & Níveis / Classes dos produtos \\
\hline \multirow{2}{*}{ Procedimentos } & - Concepção & $\checkmark$ Materiais \\
$\checkmark$ Especificações & Planejamento & $\checkmark$ Componentes \\
$\checkmark$ Padronizações & Projeto & $\checkmark$ Elementos e \\
$\checkmark$ Métodos de Ensaio & - Construção / Fabricação & Instalações \\
$\checkmark$ Terminologias & $\checkmark$ Uso & $\checkmark$ Edificações \\
$\checkmark$ Simbologias & - Operação & $\checkmark$ Conjuntos \\
$\checkmark$ Classificações & - Manutenção & Habitacionais \\
\hline
\end{tabular}

Percebe-se, portanto, que os documentos técnicos de referência do PROCONTROL possuem uma estrutura mais clara e elaborada, sendo diferenciada dos "Cadernos de Encargos" vistos anteriormente, os quais possuíam uma estrutura mais simplificada e focada na especificação do edifício.

\subsubsection{Caderno de Encargos da Prefeitura do Município de São Paulo}

Responsável: Departamento de Edificações (EDIF) da Secretaria de Serviços e Obras da Prefeitura do Município de São Paulo.

Data de publicação: a primeira edição foi publicada em 1983. Não se obteve informação sobre a última edição desse documento.

Natureza e Tipo do documento: este documento é um "Caderno de Encargos" e, portanto, sua natureza e tipo são focados na especificação do produto e dos serviços a ser exigida pelo contratante da obra, com alguns procedimentos de execução citados de forma breve. 
Origem e Objetivo: esse documento tem por objetivo "estabelecer as condições técnicas essenciais, no que tange a materiais, serviços e instalações, a serem fielmente observadas na execução de obras afetas ao EDIF". No próprio Caderno de Encargos encontra-se um item declarando que ele deve ser considerado como parte integrante dos contratos assinados entre a Prefeitura e as construtoras, valendo seu inteiro teor como se estivesse efetivamente transcrito nesses contratos.

Na elaboração deste Caderno de Encargos, segundo o mesmo, considerou-se como indispensável o conhecimento, por parte das construtoras, das normas, especificações, métodos, padronizações, classificações, terminologias e simbologias estabelecidas pela ABNT, direta ou indiretamente relacionadas com a construção civil. Existe um item específico no Caderno citando que a Prefeitura, no gerenciamento técnico e administrativo de seus contratos, deve considerar sempre o que está estabelecido no mesmo, "não admitindo, em hipótese alguma, a ignorância de parte ou do todo do Caderno de Encargos que presidirá a execução de seus serviços e obras”. Isto demonstra o caráter rigoroso previsto quanto ao cumprimento desse documento.

Público-alvo: agentes do setor da construção civil, particularmente construtoras, que pretendem executar obras para a prefeitura de São Paulo. É utilizado para balizar tais relações contratuais.

Estrutura e Conteúdo: a parte introdutória deste Caderno apresenta os objetivos e definições utilizadas, bem como algumas exigências de projetos e serviços, principalmente quanto às atribuições da construtora.

O ‘corpo’ do Caderno de Encargos está subdividido em serviços de execução da obra, apresentando-se suas especificações e critérios de medição. São considerados os seguintes serviços: serviços preliminares, trabalhos em terra, fundações, estruturas, alvenarias, impermeabilização, coberturas, esquadrias, instalações elétricas e hidro-sanitárias, revestimentos, forros, pisos e pavimentações, vidros, pintura, limpeza e serviços complementares.

Este documento não possui uma estrutura padronizada e organizada para cada serviço, sendo escrito em tópicos, identificados por alíneas, o que não o deixa muito didático.

3.2.7. Estudos para o controle de qualidade dos componentes, elementos e do produto final de conjuntos habitacionais - IPT / SICCT

Responsável: trata-se de um trabalho desenvolvido pelo IPT para a então Secretaria da Indústria, Comércio, Ciência e Tecnologia do Estado de São Paulo (SICCT).

Data de publicação: os estudos desenvolveram ao longo dos anos de 1983 e 1984. 
Natureza e Tipo do documento: estes documentos são relatórios técnicos emitidos pelo IPT para a SICCT. Os trabalhos e atividades desenvolvidos nesse Projeto IPT/SICCT deram origem a uma série de documentos técnicos de referência apresentados em anexo aos relatórios emitidos. Tais documentos, segundo IPT (1984), podem ser agrupados quanto a objetivos e metodologia em três grupos: "Recomendações para o projeto", "Procedimentos para qualificação e recebimento de materiais e componentes" e "Recomendações para o acompanhamento e a fiscalização da execução". Assim, quanto ao tipo dos documentos, os desenvolvidos nesse Projeto abrange os três gêneros de referenciais tecnológicos, ou seja, de especificação de produto, de procedimentos de execução e de controle de processo. E, além desses, ainda contempla documentos relativos aos materiais e componentes empregados na construção habitacional.

Origem e Objetivo: os estudos realizados para a SICCT tiveram como objetivo a elaboração de recomendações técnicas que pudessem subsidiar as Companhias Metropolitanas de Habitação (COHAB's) e demais órgãos ligados à construção habitacional, no Estado de São Paulo, na implantação de um Programa de Controle de Qualidade para suas obras, haja vista a constatação que o desempenho das construções habitacionais construídas em tal Estado, na época, segundo IPT (1984), estava "deixando a desejar". Além disso, também de acordo com IPT (1984), a necessidade de se elaborar as citadas recomendações justifica-se pelas deficiências dos cadernos de encargos, especificações técnicas e memoriais descritivos da maioria dos agentes do $\mathrm{BNH}$, na época. Assim desenvolveu-se este Projeto contando com a colaboração dos pesquisadores do IPT para elaborar uma documentação técnica de referência que pudesse se utilizada nas obras em questão.

Público-alvo: os documentos foram elaborados para auxiliar na especificação, na execução e no controle de serviços de obras públicas no Estado de São Paulo. Tais documentos subsidiam as COHAB's e empreiteiras na seleção de materiais e componentes utilizados em construções habitacionais e no seu recebimento em obra, subsidiam os projetistas e os técnicos das COHAB's responsáveis pela análise e aprovação de projetos e, ainda, subsidiam a construtora e a equipe de fiscalização das COHAB's. Portanto, podem ser utilizados pelos contratados e exigidos pelo contratante das obras. Assim, segundo IPT (1984), a documentação elaborada deveria ser transferida, na medida do possível, para as COHAB's existentes no Estado de SP para que pudesse ser assimilada pelo corpo técnico e incorporada à documentação desses órgãos para a licitação e contratação de obras, contratação e aprovação de projetos e controle e recebimento de serviços.

Estrutura e Conteúdo: nessa pesquisa, desenvolveram-se documentos técnicos que, para facilitar o entendimento, foram subdivididos em três módulos específicos.

O primeiro módulo consiste em "Recomendações para o projeto", destinado à avaliação e recebimento de projetos executivos das diversas partes da edificação. Trata-se de recomendações relativas a 
elementos como: fundações, alvenarias, coberturas, pisos cimentados, revestimentos de paredes com argamassas, pinturas internas e externas, instalações elétricas e instalações hidráulico-sanitárias. Visam ao estabelecimento de uma documentação básica, abrangendo as condições a serem exigidas dos diferentes elementos da edificação, que possa ser utilizada, segundo IPT (1984), como um "referencial técnico" pelos projetistas e técnicos.

Já o segundo módulo refere-se às "Recomendações para qualificação e recebimento de materiais e componentes", destinado à explicitação das exigências mínimas de qualidade dos produtos utilizados na construção habitacional e à orientação para o controle de recebimento desses produtos em canteiros de obras. Com isso, de acordo com IPT (1984), pretendia-se aprimorar a qualidade de tais produtos e otimizar o controle tecnológico dos mesmos. Estes documentos apresentam uma sistemática para a seleção e recebimento de materiais e componentes empregados na construção habitacional, estabelecendo condições a serem exigidas do fabricante para a seleção do produto, bem como condições a serem exigidas no recebimento em obra. Esse tipo de documento, relativo a materiais e componentes, não faz parte do foco do presente trabalho.

Por fim, o terceiro módulo, de particular interesse para o presente estudo, é relativo às "Recomendações para o acompanhamento e a fiscalização da execução", que contempla os aspectos principais, da execução propriamente dita em canteiro, que podem ser objeto de acompanhamento e controle, indicando os parâmetros qualitativos e quantitativos mínimos para aceitação das partes e do produto final acabado. Estes documentos têm por objetivo indicar as inspeções e vistorias que devem ser efetuadas durante a execução de cada serviço e os critérios para recebimento dos mesmos, seja parcial ou totalmente acabados. Segundo IPT (1984), o conteúdo desses documentos está baseado, preponderantemente, nas normas nacionais e estrangeiras cabíveis, naquele momento, e nos manuais de "bem construir". Na maioria das vezes, o controle é indicado por inspeção visual e equipamentos corriqueiros de obra. Tais recomendações, conforme IPT (1984), por se referirem aos mesmos assuntos dos documentos de "Recomendações para projeto", remetem em alguns pontos àqueles documentos, pois apesar de estarem mais voltados para os aspectos de "como fazer", também se destinam à aceitação do serviço pronto, necessitando da descrição de como "deve ser" o produto acabado.

Além desses três módulos, o Projeto IPT/SICCT também elaborou documentos de recomendações para avaliação de sistemas inovadores, permitindo orientar os técnicos responsáveis pelo controle da qualidade de novos sistemas construtivos. Para tanto, a metodologia de avaliação desenvolvida baseava-se no conceito de desempenho, verificando-se: segurança estrutural, segurança ao fogo, estanqueidade, conforto higrotérmico, conforto acústico e durabilidade. 
Ainda no âmbito desse Projeto, após a elaboração de todos os documentos pertinentes, foram contatados técnicos de sete COHAB's do Estado de São Paulo, da então Companhia de Desenvolvimento Habitacional $(\mathrm{CDH})^{35}$ e da então Caixa Econômica do Estado de São Paulo (NOSSA CAIXA) $^{36}$, com o objetivo de comprovar a adequabilidade dos documentos produzidos e estudar a viabilidade de sua aplicação em situações reais. Sabe-se que foram realizadas algumas reuniões, porém não se tem conhecimento a respeito de ações posteriores.

\subsubsection{Práticas DASP}

Responsável: documento elaborado pelo antigo Departamento Administrativo do Serviço Público (DASP), que era o órgão central do Sistema de Serviços Gerais (SISG), do Ministério do Planejamento, Orçamento e Gestão.

Data de publicação: o Decreto $\mathrm{n}^{\circ}$ 92.100 ${ }^{37}$, de 10 de dezembro de 1985, estabeleceu as Práticas DASP. A partir da vigência deste Decreto, revogou-se o Decreto $n^{\circ} 52.147$, de 25 de junho de 1963. Estes antigos documentos tinham sido editados pela Fundação Getúlio Vargas, em 1964, sob o título: "Obras de Edifícios Públicos". As Práticas DASP foram vigentes até 23 de julho de 1997 quando, conforme a Portaria $\mathrm{n}^{\circ}$ 2.296, foram instituídas as Práticas da SEAP (ver item 3.2.10).

Natureza e Tipo do documento: são documentos técnico-administrativos que foram exigidos a nível nacional até 1997, nos quais são estabelecidas condições mínimas, que servem de roteiro para o desenvolvimento de atividades ligadas à construção civil. No que diz respeito ao tipo dos documentos, pode-se considerar que o foco é a definição de referenciais tecnológicos para especificação e procedimentos de execução dos serviços, a serem exigidos pelo contratante da obra. A parte relativa ao controle do processo de execução é pouco abordada.

Origem e Objetivo: as Práticas DASP estabelecem as exigências mínimas de aceitabilidade na construção, conservação e demolição de edifícios públicos e imóveis residenciais a cargo dos órgãos e entidades integrantes do SISG da União. Assim, a elaboração de projetos, especificações e orçamentos, bem como a execução, controle e medição de obras e serviços de engenharia, no âmbito do SISG, subordinavam-se às Práticas DASP.

\footnotetext{
${ }^{35}$ Atual Companhia de Desenvolvimento Habitacional e Urbano do Estado de São Paulo (CDHU).

${ }^{36}$ Atual Banco Nossa Caixa S.A.

37 Informações disponíveis em: <http://www.planalto.gov.br/CCIVIL_03/decreto/1980-1989/D92100.htm>. As Práticas DASP encontram-se em anexo ao Decreto. Acesso em: 18/7/2005.
} 
Público-alvo: empresas do setor da construção civil, contratadas no âmbito do SISG, que prestem serviços como construção, conservação e demolição de edifícios públicos, servindo como regimento para as licitações e contratos entre as partes interessadas.

Estrutura e Conteúdo: antes das Práticas DASP, o Decreto de 1963 aprovava as 'Normas de Projeto e Métodos de Execução de Serviço', bem como a 'Discriminação Orçamentária' para obras de edifícios públicos, organizados pela Divisão de Edifícios Públicos do DASP. Dentre estes documentos, as 'Normas de Projeto e Métodos de Execução de Serviço' são as que fazem parte do escopo deste estudo, abordando exigências de projeto, especificamente quanto às plantas e aos esquemas que devem ser apresentados para os projetos de arquitetura, estrutural e de instalações; bem como para o levantamento planialtimétrico do terreno e sondagens. Quanto aos serviços cobertos, são apresentadas informações para: preparação do terreno, fundações, estrutura, instalações, elevadores, paredes, cobertura, esquadrias, revestimento, soleiras, rodapés, peitoris, ferragens, vidros, pavimentações, pinturas, elementos decorativos e limpeza.

Em relação aos novos documentos vigentes a partir de 1985, as Práticas DASP, no que tange ao encadeamento dos assuntos, as mesmas são basicamente compostas pelas seguintes partes:

- Objetivo;

- Terminologia ${ }^{38}$

- Condições Gerais e Específicas;

- Etapas (de Projeto, de Especificações, de Execução dos Serviços);

- Normas e Práticas Complementares;

- $\quad$ Anexo(s), quando for o caso.

Foram elaboradas 119 Práticas DASP, as quais são estruturadas de acordo com uma codificação específica para facilitar o entendimento e o acesso aos assuntos procurados. Os documentos subdividem-se nos diferentes estágios, ou etapas da obra:

- Projeto: composto de 38 "Práticas";

- Especificação: composto de 39 "Práticas";

- Orçamento: composto de 1 "Prática";

- Execução: composto de 39 "Práticas";

- Fiscalização: composto de 1 "Prática";

- Medição: composto de 1 "Prática".

\footnotetext{
${ }^{38} \mathrm{O}$ item terminologia é entendido, no documento em questão, como definições-chave para uma linguagem uniforme.
} 
Para cada etapa, têm-se os seguintes grupos (serviços): serviços técnico-profissionais; serviços preliminares; fundações e estruturas; arquitetura e elementos de urbanismo; instalações hidráulicas e sanitárias; instalações elétricas e eletrônicas; instalações mecânicas e de utilidades; instalações de prevenção e combate a incêndio; serviços complementares; serviços auxiliares e administrativos; e serviços de conservação e manutenção.

\subsubsection{Caderno de Encargos do Estado da Bahia ${ }^{39}$}

Responsável: a elaboração desse caderno de encargos foi realizada por uma equipe técnica multidisciplinar de professores da Escola Politécnica da Universidade Federal da Bahia (EPUFBA), entre 1993 e 1994. Em julho de 1997 foi criada uma equipe técnica fixa da EPUFBA, visando dar continuidade ao trabalho juntamente com técnicos da Superintendência de Construções Administrativas da Bahia (SUCAB). Nesse trabalho conjunto, formou-se um grupo integrado que contava, inclusive, com a ajuda de outros órgãos e empresas da área da construção civil. A terceira versão também foi elaborada por uma equipe técnica da EPUFB, instalada na sede da SUCAB, mediante convênio assinado com a Fundação Escola Politécnica (FEP).

Data de publicação: a primeira versão data de 1993. Foi elaborada uma segunda versão desse documento, revista e ampliada, editada em agosto de 1999. Atualmente, encontra-se em vigor a terceira versão, a qual foi publicada, eletronicamente, em novembro de 2002 e vem sendo atualizada periodicamente.

Natureza e Tipo do documento: este documento técnico é um Caderno de Encargos recente, podendo ser acessado via Internet e CD-ROM. Constitui-se, basicamente, por fichas que contêm informações sobre insumos, projetos e serviços exigidos das empresas construtoras para a realização de obras no âmbito da SUCAB. Quanto ao tipo dos documentos, caracteriza-se em referenciais tecnológicos para especificação e, principalmente, procedimentos de execução. Somente para alguns insumos são estipulados critérios de recebimento, inspeção ou controle; para os serviços, não.

Origem e Objetivo: o Caderno de Encargos da Bahia é um documento técnico que tem por objetivo a uniformização dos procedimentos para execução de obras e serviços de engenharia das edificações públicas do Estado da Bahia, por meio da apresentação de Termos de Referência para a elaboração de projetos, especificações de serviços e materiais, pretendendo abranger também índices de composições

\footnotetext{
39 Informações disponíveis em: <http://www.sucab.ba.gov.br/trab_tec_caderno_encargos.asp>, acesso em: 29/6/2005. Também foram obtidas informações em publicações cedidas pela Coordenadora de Qualidade e Pesquisa Tecnológica da Superintendência de Construções Administrativas da Bahia, Dra. Ana Luiza Fontes.
} 
de preços unitários, além de determinar a qualidade e o tipo dos materiais e equipamentos a serem empregados.

Tal documento insere-se na política de "profissionalização" na contratação de obras públicas do Estado, aonde vem sendo desenvolvida uma série de trabalhos técnicos, buscando a melhoria da qualidade das edificações do setor público. Assim, esse Caderno de Encargos visa à padronização e racionalização das obras civis da Bahia, passando a ser parte integrante de todo Edital da SUCAB.

As principais etapas para execução da segunda versão, segundo um dos documentos enviados pela SUCAB, foram: "entendimento do processo para execução do serviço (estudos do detalhamento de anteprojetos / projetos das obras); consulta das fontes de pesquisa / fabricantes (catálogos, livros e revistas técnicas, especificações similares etc.); correção e complementação das especificações da primeira versão; visitas às obras; revisão de textos junto a consultores externos e técnicos da SUCAB".

A versão atual objetiva definir as condições gerais e particulares a serem obedecidas não somente na execução de obras e serviços, assim como na elaboração e apresentação dos projetos elaborados pela SUCAB, direta ou indiretamente.

Público-alvo: para as empresas participantes de licitação na SUCAB, tornou-se obrigatória a aquisição do Caderno de Encargos da Bahia, como documento básico de uniformização dos procedimentos para a elaboração de projetos e execução de obras e serviços de engenharia. Além disso, este trabalho tornou-se referencial para outros órgãos da administração pública estadual.

Estrutura e Conteúdo: em sua primeira versão, esse caderno de encargos foi publicado em três Módulos: Projetos, Materiais e Serviços. Com mudanças substanciais na estruturação dos códigos, nos campos relativos aos termos de referência para Projetos, Insumos e Serviços, a segunda versão possibilitou maior flexibilidade e clareza na elaboração de orçamentos, contendo 22 Termos de Referência no Módulo I (Projetos), 2.849 itens no Módulo II (Insumos) e 3.060 itens no Módulo III (Serviços). Essa versão foi disponibilizada em CD-ROM para as empresas de construção civil cadastradas na SUCAB e alguns órgãos públicos que contratam direta ou indiretamente serviços de construção e reforma.

A terceira, e atual, versão especifica a qualidade e o tipo de materiais e equipamentos a serem empregados, bem como os procedimentos a adotar na execução, controle e recebimento de projetos, obras e serviços. Nessa versão, foram adicionados alguns itens e outros foram excluídos, obtendo-se um total de 2.844 itens no Módulo II (Insumos) e 3.666 itens no Módulo III (Serviços) e sendo mantidos os 22 Termos de Referência no Módulo I (Projetos). 
A novidade na terceira versão desse Caderno de Encargos foi a elaboração do chamado 'Caderno de Encargos Único do Estado da Bahia (CEUBa)', já enriquecido com as especificações dos serviços / insumos do Serviço de Construções Escolares (CONESC) e Serviço de Engenharia e Manutenção de Unidades de Saúde (SEMUS), que está sendo, também, complementado com a incorporação dos serviços da Companhia de Desenvolvimento Urbano do Estado da Bahia (CONDER) e Departamento de Infra-estrutura de Transportes da Bahia (DERBA). Esta parceria faz parte do processo de centralização das atividades para a criação de um banco de dados para orçamento composto de normas, especificações e métodos de execução para as obras públicas no Estado da Bahia.

A terceira versão foi publicada na Internet, com acesso pelo site da SUCAB, dando início ao projeto de reformulação do Caderno e vislumbrando a implementação de aspectos inovadores, como a interação com o Programa de Qualidade das Obras Públicas da Bahia (QUALIOP) e a incorporação de requisitos documentais do $\mathrm{SiAC}$.

Atualmente, o Caderno de Encargos da SUCAB é um manual que funciona como uma base de dados digital, onde se podem fazer consultas às informações de projetos, insumos e serviços. A vantagem da publicação na web é a periodicidade da sua atualização, sempre que detectada a sua necessidade, e a implantação de dispositivos como sistema de busca, para facilitar a localização de itens desejados. Além disso, existe um formulário eletrônico para críticas e sugestões, objetivando o aprimoramento do trabalho. As informações são disponibilizadas em módulos (insumos, projetos e serviços) onde são estabelecidas as diretrizes básicas para elaboração de especificações dos serviços contratados pela SUCAB, obedecendo a uma codificação. Na versão atual tem-se:

- Insumos:

O módulo de insumos contém elementos para: fundações, formas e escoramentos, elementos em aço, fechamentos, revestimentos / acabamentos, coberturas, fixações, instalações elétricas, instalações hidráulicas e drenagens, instalações especiais, impermeabilizações, paisagismo, urbanização, elementos decorativos / mobiliários. As fichas de insumos são padronizadas e apresentadas de acordo com os seguintes tópicos: descrição do insumo, características, utilização, inspeção para recebimento, armazenamento e unidade de compra.

- Projetos:

Quanto aos projetos, o Caderno de Encargos da Bahia contempla: estudos e projetos iniciais, projetos estruturais, projetos de instalações, projetos de tratamentos, isolações e impermeabilizações e projetos complementares. São termos de referência que definem algumas disposições preliminares, e aspectos relativos à apresentação e à entrega do projeto. 
- Serviços:

No que diz respeito aos serviços, tem-se: serviços iniciais, instalações de canteiro, movimento de terras, drenagens, escoramentos e contenções, cargas e transportes, misturas e injeções, fundações, armaduras, formas, elementos de fechamento, esquadrias e vidros, revestimentos, pavimentações, pinturas, coberturas, instalações elétricas e eletrônicas, instalações hidráulicas, instalações especiais, impermeabilizações, isolações e tratamentos, serviços complementares, diversos e equipamentos.

As fichas de serviços são organizadas, de fácil acesso e padronizadas. Apresentam-se de acordo com os seguintes itens:

- descrição do serviço;

- recomendações;

- procedimentos para execução; e

- $\quad$ unidade de compra.

Além disso, tais fichas são sucintas, objetivas e mostram a data da última atualização.

\subsubsection{Manual de Obras Públicas - Edificações (Práticas da SEAP)}

Responsável: Secretaria de Estado da Administração e Patrimônio (SEAP), no âmbito da Secretaria de Logística e Tecnologia da Informação, do Ministério do Planejamento, Orçamento e Gestão.

Data de publicação: 23 de julho de 1997, conforme a Portaria no 2.296, instituída pelo então Ministro de Estado da Administração Federal e Reforma do Estado. As Práticas da SEAP atualizam e complementam as Práticas DASP, que eram vigentes até então, desde 10 de dezembro de 1985 (ver item 3.2.8). Não se obteve informações sobre eventuais mecanismos de atualização das Práticas da SEAP, devendo estar válidas até hoje.

Natureza e Tipo do documento: as Práticas da SEAP são documentos técnico-administrativos, vigentes na Administração Pública Federal. Possuem três módulos específicos: "Práticas de Projeto", "Práticas de Construção" e "Práticas de Manutenção", englobando os tipos de referenciais tecnológicos para especificação e procedimentos de execução dos serviços e extrapolando o escopo do documento para a etapa de manutenção do edifício. Além disso, para cada serviço abordado nas "Práticas de Construção", tem-se um Anexo com os respectivos procedimentos de fiscalização, abrangendo, desse modo, os referenciais tecnológicos de controle de processo também. Portanto, as Práticas da SEAP incorporam os três tipos de documento de interesse para esse trabalho, acrescentando, ainda, os procedimentos exigidos para a manutenção das edificações públicas. 
Origem e Objetivo: as Práticas da SEAP originaram-se das Práticas DASP, considerando, conforme citado na Portaria $\mathrm{n}^{\circ}$ 2296, as seguintes necessidades: instituir procedimentos que consagrassem os avanços tecnológicos inerentes ao projeto, construção, manutenção e demolição de edifícios públicos; reconfigurar a estrutura das normas em três módulos específicos, compostos respectivamente pelas Práticas de Projeto, Práticas de Construção e Práticas de Manutenção; dispor sobre as atividades de manutenção, visando à preservação do desempenho e ao prolongamento da vida útil e à redução de desperdícios e investimentos na recuperação dos edifícios públicos; e incorporar disposições pertinentes à economia e racionalização do uso de energia, garantia e controle de qualidade, e preservação do meio ambiente. Estes documentos têm por objetivo servir como exigências mínimas de aceitabilidade no projeto, construção, manutenção e demolição de edifícios públicos a cargo dos órgãos e entidades integrantes do Sistema de Serviços Gerais (SISG) da União.

Público-alvo: empresas do setor da construção civil, contratadas no âmbito do SISG, que prestem serviços como projeto, construção, conservação e demolição de edifícios públicos, servindo como regimento para as licitações e contratos entre as partes interessadas. Além disso, segundo citado no próprio documento, as Práticas da SEAP constituem-se em material de consulta para os profissionais e empresas do setor.

Estrutura e Conteúdo: os três módulos específicos em que se estruturam as mencionadas Práticas agrupam disposições sobre as atividades de projeto, construção e manutenção, com vistas à preservação do desempenho, ao prolongamento da vida útil e à redução do desperdício e dos investimentos na recuperação dos edifícios públicos. Os documentos consideram, também, os aspectos inerentes à garantia e ao controle de qualidade, à preservação do meio ambiente, à segurança e saúde do trabalhador, à conservação de energia e à eliminação de barreiras arquitetônicas ao acesso de deficientes físicos, entre outros.

As Práticas de Projeto, primeiramente, apresentam informações gerais sobre a elaboração e apresentação dos projetos, incluindo anexo de orçamento. A seguir, são abordados os seguintes serviços: topográficos, geotécnicos, serviços preliminares, fundações e estruturas, arquitetura e elementos de urbanismo, instalações hidráulicas e sanitárias, instalações elétricas e eletrônicas, instalações mecânicas e de utilidades. Para cada serviço, tem-se uma estrutura padrão de apresentação:

- 1. Objetivo

- 2. Terminologia

- 3. Condições Gerais

- 4. Condições Específicas

- 5. Etapas de Projeto 
- 6. Normas e Práticas Complementares

- ANEXO - Especificação

As Práticas de Construção também fornecem, inicialmente, um panorama geral para a construção dos edifícios, incluindo um modelo de Relatório de Andamento dos Serviços e Obras. Os serviços abordados são os seguintes: serviços preliminares, fundações e estruturas, arquitetura e elementos de urbanismo, instalações hidráulicas e sanitárias, instalações elétricas e eletrônicas, instalações mecânicas e de utilidades, instalações de prevenção e combate à incêndio e serviços complementares. Tais serviços são estruturados de acordo com os seguintes itens:

- 1 . Objetivo

- 2. Execução dos Serviços

- 3. Normas e Práticas Complementares

- ANEXO - Fiscalização

O item relativo à execução dos serviços apresenta, em geral, os materiais e equipamentos utilizados, o processo executivo e o recebimento do serviço. Já o anexo sobre a fiscalização apresenta atividades específicas que devem ser realizadas, além das atividades mencionadas na Prática Geral de Construção, para o controle do processo de execução dos serviços.

Por fim, as Práticas de Manutenção, além das condições gerais para a manutenção dos edifícios públicos, apresenta os "Procedimentos e Rotinas de Conservação e Manutenção" para: arquitetura e elementos de urbanismo, fundações e estruturas, instalações hidráulicas e sanitárias, instalações elétricas e eletrônicas, instalações de prevenção e combate à incêndio, instalações mecânicas e de utilidades. Este documento possui, ainda, um item sobre a periodicidade das inspeções, estabelecendose que devem ser em função da intensidade de uso das instalações e componentes, das condições locais, experiência do Contratante e recomendações dos fabricantes e fornecedores.

\subsubsection{Manual Técnico de Engenharia da CAIXA para o Estado de São Paulo}

Responsável: Caixa Econômica Federal sendo, porém, um documento válido apenas no Estado de São Paulo. Existem, igualmente, Manuais Técnicos aplicáveis a outros Estados.

Data de publicação: a versão inicial do documento, editada em dezembro de 1999, esteve sendo revista entre março de 2001 e março de 2002, acolhendo contribuições diversas dos empregados da CAIXA: Escritórios de Negócios e Gerência de Filial de Apoio ao Desenvolvimento Urbano (GIDUR) do Estado de São Paulo, em especial do corpo de engenheiros e arquitetos; e também, acolhendo contribuições significativas dos construtores e incorporadores. As soluções de consenso foram 
incorporadas, e uma segunda versão foi editada, entrando em vigência a partir de agosto de 2002 e sendo válida até o presente momento.

Natureza e Tipo do documento: o Manual Técnico de Engenharia (MTE) é parte integrante do Caderno de Orientações de Empreendimento (COE), o qual contempla procedimentos da CAIXA para concessão de financiamento ao setor privado no Estado de São Paulo. Além do MTE, o COE também contempla o Manual Técnico do Serviço Social. Quanto ao tipo do documento em questão, pode-se afirmar que seu foco situa-se, basicamente, na especificação do produto, uma vez que apresenta as condições mínimas e as exigências do empreendimento que devem ser consideradas na etapa de projeto. Não apresenta procedimentos de execução nem de controle dos serviços, possuindo uma natureza um tanto quanto diferente dos demais documentos analisados nesse capítulo.

Origem e Objetivo: o MTE é fruto de um trabalho conjunto entre a CAIXA-SP e entidades representativas da indústria da construção Civil no Estado de São Paulo: SindusCon-SP, Associação Paulista de Empresários de Obras Públicas (APEOP) e Sindicato das Empresas de Compra, Venda, Locação e Administração de Imóveis Comerciais e Residenciais do Estado de São Paulo (SECOVI). Tal manual tem por princípios: uniformizar os documentos a serem apresentados; orientar o preenchimento dos documentos; tornar transparentes os aspectos relevantes das análises da CAIXASP; e agilizar o trâmite do processo na CAIXA-SP.

Público-alvo: o MTE aplica-se aos empreendimentos passíveis de enquadramento em programas específicos de financiamento pela CAIXA-SP. É utilizado por empresas do setor da construção civil, como orientação para apresentação de empreendimentos habitacionais do setor privado. Mesmo obedecendo a uma estruturação de assuntos padronizada nacionalmente, predominantemente o MTE respeita as peculiaridades estaduais. Assim, por exemplo, o manual apresentado no presente estudo tem aplicabilidade apenas no Estado de São Paulo.

Estrutura e Conteúdo: em relação ao seu conteúdo, o MTE inicialmente apresenta a documentação de engenharia exigida pela CAIXA-SP para concessão de financiamento, informando quando prescindíveis e instruindo como elaborar os documentos. No Capítulo 2 são apresentados os aspectos relevantes das análises da CAIXA-SP, tornando transparentes e uniformes os critérios de análise técnica pelo seu corpo de Engenheiros e Arquitetos. No Capítulo 3 são apresentados aspectos relevantes durante o acompanhamento de obras e conseqüente liberação de recursos. No Capítulo 4, a título informativo, são apresentados assuntos que tendem a interferir em todo o setor da construção civil: programas de qualidade, evolução tecnológica, impacto ambiental, etc. Por fim, apresentam-se todos os modelos padronizados pela CAIXA que podem auxiliar os proponentes. 
A parte de interesse para o presente estudo é o Capítulo 2, o qual contém um item intitulado “Condições Mínimas e Exigências da Caixa Econômica Federal - Estado de SP”. O conceito de condição mínima adotado pela CAIXA, segundo o MTE, não deve ser confundido com o conceito de habitabilidade mínima. A condição da CAIXA almeja atingir um padrão de qualidade adequado às características regionais, de ordem cultural, econômica e social, enquanto que o conceito de habitabilidade mínima é único em qualquer situação. As condições mínimas da CAIXA variam em função da região, do público alvo e do programa habitacional.

Em relação a essas condições mínimas e exigências da CAIXA tem-se, para as unidades habitacionais, especificações para: fundações, estrutura, alvenaria, esquadrias, cobertura, impermeabilização, revestimento interno e pintura, revestimento externo, pisos e calçadas, soleira e peitoril, instalações elétricas e telefonia, instalações hidro-sanitárias e complementos.

\subsubsection{Requisitos e Critérios Mínimos da CAIXA}

Existem, atualmente, cinco documentos de "requisitos e critérios mínimos a serem atendidos para solicitação de financiamento de edifícios junto à CAIXA" que se encontram disponíveis no site da CAIXA $^{40}$, referentes ao item "Inovação e Transferência de Tecnologia em Desenvolvimento Urbano Apoio ao Desenvolvimento, Aperfeiçoamento e Disponibilização de Informações relacionadas à Habitação e Saneamento", relacionados à "Parceria para a divulgação e disseminação de tecnologias da habitação". Os documentos contemplam edifícios habitacionais que utilizam:

- Gesso Acartonado;

- Estruturas em Aço;

- Alvenaria Estrutural;

- Steel Framing;

- Concreto Celular.

Devido ao fato de os três fabricantes de chapas de gesso acartonado atuantes no Brasil serem de origem européia, e fortemente ligados à França, o documento de requisitos e critérios da CAIXA referente a tal tecnologia acabou sendo elaborado sob influência da tradição deste país. Assim, segundo o CSTB (2002), esse documento pode ser considerado como sendo a primeira versão nacional de um documento desenvolvido conforme a orientação dos Documentos Técnicos Unificados, da França, os quais são detalhados no Capítulo 4. O documento em questão foi elaborado por

${ }^{40}$ Documentos disponíveis em: <https://webp.caixa.gov.br/urbanizacao/caixacidade/links_menu_lat_esq.asp>. Acesso em: 6/1/2006. 
profissionais brasileiros e pelo principal financiador da construção no Brasil, a CAIXA. Os demais documentos também foram desenvolvidos, posteriormente, segundo as mesmas premissas. Em vista disso, e do interesse aqui pelos DTU franceses, alguns tópicos de tais documentos, como sua estrutura, são apresentados mais detalhadamente.

Responsável: o responsável pela condução dos trabalhos e elaboração dos documentos é a CAIXA. Porém, é importante ressaltar que tais documentos, em geral, foram elaborados em parceria com especialistas, instituições, sindicatos, associações e entidades representativas de cada setor, com apoio de consultoria externa especializada e de maneira articulada com os fabricantes do produto e construtoras que pretendem utilizá-lo. Por exemplo, o documento sobre 'alvenaria estrutural' teve o apoio da Associação Nacional da Indústria Cerâmica (ANICER) e Associação Brasileira de Cimento Portland $(\mathrm{ABCP})$ e os documentos sobre 'estruturas em aço' e 'steel frame' tiveram o apoio do Instituto Brasileiro de Siderurgia (IBS), do Centro Brasileiro da Construção em Aço (CBCA) e do SindusCon-SP, dentre outros. O documento do gesso acartonado teve o apoio da atual Associação Brasileira dos Fabricantes de Chapas para Drywall (DRYWALL). Já o documento que aborda as paredes de concreto celular foi elaborado sob a coordenação do Departamento de Apoio e Controle Técnico de FURNAS - Centrais Elétricas S.A. e com a colaboração técnica da ABCP.

Data de publicação: a data de publicação da última versão encontrada no site, de cada documento, pode ser vista na Tabela 8 a seguir.

Tabela 8 - Documentos de Requisitos e Critérios Mínimos da CAIXA.

(Fonte: https://webp.caixa.gov.br/urbanizacao/caixacidade/links_menu_lat_esq.asp)

\begin{tabular}{l|c}
\hline \multicolumn{1}{c}{ Título do documento } & Data de publicação \\
\hline $\begin{array}{l}\text { "Paredes de gesso acartonado: requisitos para financiamento pela } \\
\text { CAIXA" }\end{array}$ & Setembro de 2001 \\
\hline $\begin{array}{l}\text { "Edificações habitacionais convencionais estruturadas em aço: } \\
\text { requisitos e critérios mínimos para financiamento pela CAIXA" }\end{array}$ & Maio de 2002 \\
\hline $\begin{array}{l}\text { "Alvenaria estrutural: materiais, execução da estrutura e controle } \\
\text { tecnológico" }\end{array}$ & Março de 2003 \\
\hline $\begin{array}{l}\text { "Sistema construtivo utilizando perfis estruturais formados a frio de } \\
\text { financiamento (Steel Framing): requisitos e condições mínimos para }\end{array}$ & Agosto de 2003 \\
$\begin{array}{l}\text { "Avaliações de sistemas construtivos e estabelecimento de requisitos } \\
\text { para edificações térreas com paredes de concreto celular" }\end{array}$ & Dezembro de 2003 \\
\hline
\end{tabular}

Natureza e Tipo dos documentos: trata-se de documentos analisados, discutidos e revisados por grupos de trabalho específicos, que contam com a participação de representantes dos respectivos setores, 
abrangendo produtores e usuários das técnicas abordadas. A própria CAIXA $^{41}$ afirma que esse processo "exemplifica a nova forma de implementação dos programas habitacionais de Governo, conciliando os interesses das partes envolvidas e se assegurando previamente da garantia de desempenho da tecnologia a ser empregada". Quanto ao tipo dos documentos, de maneira geral, estes englobam referenciais tecnológicos de especificação de produto, de procedimentos de execução e de controle de processo, ou seja, contempla os três tipos de documentos, incluindo exigências de projeto e de desempenho.

Origem e Objetivo: os documentos estabelecem os requisitos e critérios mínimos a serem atendidos nos respectivos processos construtivos para solicitação de financiamentos junto à CAIXA. Tais documentos são resultados de uma ação de consolidação e aperfeiçoamento de processos construtivos 'inovadores' como o gesso acartonado, steel frame e concreto celular ou 'convencionais' como a alvenaria estrutural. Por exemplo, no caso do gesso acartonado, a origem do documento deve-se à falta de uma normalização nacional específica vigente na época, voltada, principalmente, ao processo construtivo e suas interferências com as demais partes do edifício ${ }^{42}$, além do fato de ser uma tecnologia com uso recentemente difundido entre as empresas construtoras. Foram esses motivos que também incentivaram o desenvolvimento dos documentos que abordam as demais inovações tecnológicas, por exemplo, o de steel frame, o qual, em função da inexistência de normalização brasileira sobre o sistema, foi fundamentado em normas e experiências internacionais, em especial as norte-americanas, assim como no exame dos projetos já edificados no Brasil.

Já quanto à origem do documento que contempla tecnologia convencional, por exemplo a alvenaria estrutural, tem-se que, apesar de ser um processo construtivo tradicional, se verificou, de acordo com o próprio documento em questão, a ocorrência de algumas patologias em empreendimentos executados no passado, aliada à inexistência de um conjunto normativo completo sobre o assunto. Assim, esses foram os motivos que levaram ao estabelecimento, pela CAIXA, de requisitos e critérios a serem observados na execução de edificações em alvenaria estrutural. Os mesmos motivos levaram à elaboração do documento sobre estruturas em aço, na tentativa de minimizar a repetição de algumas patologias encontradas no seu processo construtivo.

Público-alvo: empresas do setor da construção civil que trabalham com tais inovações tecnológicas (gesso acartonado, steel frame ou concreto celular) ou procedimentos convencionais de execução de edifícios (alvenaria estrutural ou estruturas em aço), como construtoras, fabricantes de tais produtos ou

\footnotetext{
${ }^{41}$ Informações disponíveis em: <https://webp.caixa.gov.br/urbanizacao/inovacoes/inovacoes.asp>. Acesso em: 5/7/2005.

${ }^{42}$ Atualmente, existem normas técnicas brasileiras para as chapas de gesso acartonado (requisitos, características físicas e geométricas) e para os perfis de aço utilizados para sistemas de vedações em gesso acartonado (requisitos), porém ainda não existem para os outros componentes deste processo construtivo nem para o seu procedimento de execução.
} 
sistemas, dentre outros. Os documentos citam especificações, procedimentos e controles exigidos pelo agente financeiro das obras (CAIXA), e que devem ser cumpridos pelos "contratados". Por serem documentos escritos de forma clara e objetiva, de fácil entendimento, além de conterem critérios de projeto e de desempenho desejável das tecnologias, podem ser utilizados por qualquer profissional do setor da construção civil, como orientação.

Estrutura e Conteúdo:

- Gesso acartonado

O estabelecimento de condições mínimas exigíveis foi feito tendo em vista as recomendações internacionais para a produção de vedações verticais com chapas de gesso acartonado, as Referências Técnicas (RT) ${ }^{43}$ produzidas pelo IPT, afeitas aos produtos nacionais, bem como a experiência de empresas construtoras que vinham empregando essa tecnologia em seus empreendimentos. Segundo o documento, busca-se estabelecer a 'boa prática' para a elaboração de projeto, a execução e o controle do recebimento de vedações verticais com chapas de gesso acartonado.

A estrutura do documento de requisitos para paredes de gesso acartonado é apresentada a seguir:

1. Introdução

2. Objetivo

3. Limitações de emprego do sistema

4. Exigências para emprego do sistema

4.1. Exigências de desempenho

\subsection{Exigências de projeto}

4.3. Exigências de execução e controle de recebimento

5. Garantias e responsabilidades

\subsection{Da construtora}

\subsection{Do fabricante}

6. Validade deste documento

7. Bibliografia de referência

8. Ficha técnica

\footnotetext{
${ }^{43}$ A primeira Referência Técnica (RT) concedida pelo IPT, para o gesso acartonado (considerado uma tecnologia inovadora), foi em 1997. Quando da elaboração do documento da CAIXA, já haviam sido concedidas seis RT para as três empresas fabricantes no Brasil, sendo as três primeiras RT para produtos importados e as três últimas para produtos de fabricação nacional.
} 
- Estruturas em aço

Este documento apresenta os requisitos e critérios mínimos aplicados em edifícios e casas habitacionais, com utilização de estruturas de aço como pilar, viga, laje e estrutura de cobertura, nos empreendimentos objeto de financiamento pela CAIXA.

Nos requisitos de projeto, aborda-se os aspectos do aço, suas especificações e dimensionamento, sempre fazendo referência à utilização das normas existentes. Nos requisitos de desempenho, a segurança estrutural e a segurança ao fogo também são direcionadas às normas existentes, sendo que as ligações do aço aos sub-sistemas de vedação, por não estarem contemplados em norma, são referenciados em Anexos indicando seus procedimentos típicos. O caso específico da ligação entre as alvenarias e as estruturas de aço também está contemplado em Anexo no documento, o qual mostra os procedimentos típicos de tais ligações.

A estrutura do documento em questão é apresentada a seguir:

1. Introdução

2. Objetivo

3. Requisitos para emprego

3.1. Parâmetros gerais

3.2. Requisitos de projeto

3.3. Requisitos de desempenho

3.4. Requisitos de execução e recebimento

3.5. Recomendações para reformas e ampliações

4. Garantias e responsabilidades

4.1. Da construtora

4.2. Do fabricante da estrutura

5. Validade deste documento

- Alvenaria estrutural

Este documento estabelece os critérios e exigências para a construção da estrutura de edifícios habitacionais quando esta for constituída essencialmente de paredes resistentes de alvenaria, nos empreendimentos objeto de financiamento ou contratação pela CAIXA. Porém, algumas características restringem o escopo deste documento, referindo-se o mesmo apenas a edifícios de multipavimentos (habitação coletiva) de 3 a 5 pavimentos; que empreguem processos construtivos de alvenaria estrutural com uma das seguintes tipologias: de alvenaria nãoarmada (auto-suporte) e alvenaria parcialmente armada; e que utilizem paredes de alvenaria de blocos cerâmicos com função estrutural ou de blocos vazados de concreto. 
A estrutura do documento de requisitos para alvenaria estrutural, é apresentada a seguir:

1. Introdução

2. Objetivo

3. Definições e conceitos

4. Exigências para garantia do desempenho estrutural e da durabilidade dos edifícios em alvenaria

5. Exigências e critérios mínimos quanto aos materiais e componentes a serem empregados na execução de paredes de alvenaria

6. Exigências essenciais quanto aos métodos e técnicas construtivas a serem empregados na produção da estrutura de edifícios

7. Exigências e parâmetros para o controle tecnológico a ser adotado na produção da estrutura de edifícios em alvenaria estrutural

8. Bibliografia de referência

- Steel frame

Este documento fornece subsídios para o estabelecimento de critérios de análise de solicitação de financiamento para a construção de edificações com sistema steel frame e, desta forma, possibilita a incorporação desse sistema como mais uma alternativa construtiva dentre aquelas usualmente utilizadas nos empreendimentos habitacionais financiados pela CAIXA. Pode ser aplicado a edificações com até quatro pavimentos.

A estrutura do documento pode ser vista a seguir, ressaltando-se que as exigências de desempenho incluem desempenho estrutural, segurança ao fogo, estanqueidade à água, conforto térmico e acústico e durabilidade.

1. Introdução

2. Objetivo

3. Limitações para emprego do sistema

4. Caracterização do sistema

5. Exigências de desempenho do sistema

6. Componentes do sistema

7. Especificações dos perfis

8. Garantias e responsabilidades

\subsection{Da construtora}

8.2. Do fabricante dos perfis de aço da estrutura

8.3. Dos fabricantes dos demais materiais componentes do sistema construtivo em steel framing

9. Validade deste documento 
10. Disposições transitórias

11. Considerações finais

12. Ficha técnica, glossário

13. Referências bibliográficas

14. Relação de normas citadas neste documento

- Concreto celular

Este documento descreve as conclusões da avaliação de desempenho do sistema construtivo adotado nas habitações construídas em concreto celular espumoso, fundido no local, para todo o país, bem como estabelece os requisitos técnicos que este sistema deva seguir. A estrutura do documento pode ser observada a seguir.

1. Introdução

2. Objeto e objetivo

3. Método

4. Normas e documentos complementares

5. Avaliação do sistema construtivo

6. Requisitos para projetos

7. Garantias e responsabilidades

8. Validade

9. Termos de responsabilidade

10. Referência bibliográfica

\subsubsection{Recomendações Técnicas HABITARE}

Responsável: a série de publicação "Recomendações Técnicas" está inserida no Programa de Tecnologia de Habitação (HABITARE), da FINEP. O volume 1 dessa série, intitulado "Recomendações técnicas para revestimentos de argamassas: boas práticas em projeto, execução e avaliação", teve a parceria da ANTAC, o apoio financeiro da FINEP e da CAIXA e o apoio institucional do Consórcio Setorial para Inovação em Tecnologia de Revestimentos de Argamassa (CONSITRA), da Associação Brasileira da Argamassa Industrializada (ABAI), do SindusCon-SP, da ABCP, da Associação Brasileira das Empresas de Tecnologia da Construção Civil (ABRATEC), da Escola Politécnica da Universidade de São Paulo (EPUSP) e da Universidade Federal de Goiás (UFG). Assim, esta primeira edição, segundo o próprio documento, reúne recomendações que são consenso entre indústria, projetistas e consultores da área. Os autores foram os engenheiros: Luiz Henrique Ceotto, Ragueb Chauki Banduk e Elza Hissae Nakakura. 
Data de publicação: este documento foi publicado em 2005.

Natureza e Tipo do documento: este primeiro volume da série "Recomendações Técnicas HABITARE" trata-se de um livro didático e, portanto, não tem a função de balizar relações contratuais, como alguns dos documentos abordados nesse trabalho. O livro trata somente um serviço, no caso o revestimento de argamassa e, para o mesmo, cita as boas práticas em projeto, execução e avaliação (controle). Desse modo, o documento contempla os três tipos de referenciais tecnológicos: para especificação, procedimentos de execução e controle do processo.

Origem e Objetivo: segundo informações contidas no próprio documento, o Programa HABITARE foi criado com o objetivo de estimular o desenvolvimento de tecnologias para habitação e, atualmente, está também apoiando a edição da série "Recomendações Técnicas HABITARE" . O objetivo é colaborar com a socialização e transferência de conhecimentos. Assim, essa série, que é bastante recente, deve oferecer mais um mecanismo para ajudar na qualificação de profissionais da área de construção e na melhoria da qualidade da habitação. Portanto, a publicação desse primeiro volume, de acordo com o mesmo, foi organizada com o objetivo de informar a sociedade técnica de engenharia sobre o atual estágio do conhecimento e as práticas mais recomendadas para projeto e aplicação de revestimentos de argamassa em edifícios.

Público-alvo: profissionais e empresas do setor da construção civil, em geral. Por ser um material didático, serve como orientação inclusive para estudantes de engenharia ou arquitetura. Segundo o próprio documento, a expectativa é a de que tal publicação seja uma referência para diversos profissionais da cadeia produtiva da construção, auxiliando na busca de soluções para problemas relacionados aos revestimentos de argamassas.

Estrutura e Conteúdo: este documento é subdividido em projeto, planejamento, produção e conservação do revestimento. Na introdução do trabalho, um histórico recupera o início do uso das argamassas, a evolução e causas dos principais problemas. A seguir, o livro traz informações sobre o conteúdo básico de um projeto de revestimento de fachada executado em argamassa, as principais atribuições e responsabilidades de projetistas, administradores de obras, fabricantes de argamassas e profissionais diretamente ligados à construção. A publicação também contempla orientações sobre planejamento, como o processo de escolha e contratação de profissionais. São relacionadas informações que devem ser apresentadas por fornecedores, assim como indicações sobre processos de avaliação de argamassas, tanto em estado fresco como endurecido. Com relação à produção, trata de temas fundamentais, como treinamento, recebimento, armazenagem, rastreabilidade, preparo e controle. Os temas inspeção das fachadas, conservação e limpeza também são contemplados. 


\subsubsection{Guia da Qualidade dos Processos Construtivos}

Responsável: o Projeto "Guia da Qualidade dos Processos Construtivos"44 teve como promotores o Serviço Nacional de Aprendizagem Industrial do Estado do Rio de Janeiro (SENAI-RJ), o Sindicato da Indústria da Construção Civil no Estado do Rio de Janeiro (SindusCon-Rio), o Clube da Qualidade na Construção ${ }^{45}$ e ainda contou com o patrocínio do Serviço Brasileiro de Apoio às Micro e Pequenas Empresas do Estado do Rio de Janeiro (Sebrae-RJ).

Data de publicação: o Guia ainda encontra-se em desenvolvimento, com previsão de lançamento para o $2^{\circ}$ semestre de 2006. Portanto, a idéia aqui é somente registrar mais uma recente e importante iniciativa, que está sendo implementada no setor da construção de edifícios, no que diz respeito ao desenvolvimento de uma documentação técnica de referência.

Natureza e Tipo do documento: Trata-se de um software, que inclui procedimentos de execução e inspeção dos serviços das obras, dentre outros documentos relevantes para o processo de produção de edifícios. Quanto aos tipos de documentos, são contemplados os referenciais tecnológicos de procedimentos de execução e de controle do processo de execução.

Origem e Objetivo: o Projeto originou-se no âmbito da Comissão de Materiais, Tecnologia, Qualidade e Produtividade (COMAT) do SindusCon-Rio, a partir da proposta da empresa Prisma Projetos e Construções Ltda apresentada na reunião da Comissão de abril de 2001. O Projeto recebeu a aprovação na reunião da COMAT, que também se constitui como fórum de análises e decisão do Clube da Qualidade na Construção, passando a incorporar às ações do Clube. Para a elaboração e o desenvolvimento do Projeto constituiu-se a Comissão de Estudo "Construção Padronizada", formada por empresas e entidades participantes da COMAT. Na sua formação inicial, a Comissão de Estudos contou com representantes do SENAI-RJ, da Escola de Engenharia da Universidade Federal do Rio de Janeiro (UFRJ), da empresa Prisma, dentre outras empresas do setor. Posteriormente, tal Comissão de Estudo foi renomeada para Comissão de Estudo "Processos Construtivos" e adquiriu a sua formação definitiva, assumindo a responsabilidade pelo desenvolvimento técnico do Projeto. Os recursos financeiros necessários para a realização desse Projeto foram disponibilizados, inicialmente, pelo Clube da Qualidade na Construção.

\footnotetext{
${ }^{44}$ As informações a respeito do Guia foram cedidas pelo Sr. Roberto da Cunha, que é o Coordenador Tecnológico de Produtos de Construção Civil, do Senai-RJ, e um dos responsáveis pela elaboração do mesmo.

${ }^{45}$ O Clube da Qualidade na Construção é uma ação decorrente do convênio firmado entre o SENAI-RJ e o SindusCon-Rio, em 14/10/1994, para implantação e execução de ações de melhoria da qualidade e produtividade nas empresas do setor no Estado do Rio de Janeiro.
} 
No ano de 2003 o Sebrae-RJ integrou-se ao Projeto, na qualidade de entidade co-patrocinadora, através de parceria com o Sistema FIRJAN (Federação das Indústrias do Estado do Rio de Janeiro) consubstanciada no Acordo de Cooperação Técnica Financeira (ACT). Cabe, ainda, destacar que a empresa Prisma, desde 2001, implantou um sistema de planejamento e controle de obras que estruturava as informações com base no mapeamento das atividades decorrentes dos métodos construtivos $^{46}$ para a produção de uma edificação, estabelecendo um sentido lógico para execução da obra, permitindo que se percebesse a obra como uma linha de montagem, de modo análogo à indústria tradicional. O presente Projeto foi, portanto, concebido a partir do seu desenvolvimento experimental em canteiro de obras, idealizado pela empresa Prisma.

Assim, os objetivos desse Guia são: definir, mapear e estruturar os métodos construtivos de edificações e suas inter-relações, constituindo-se em ferramenta para o planejamento e gerenciamento no canteiro de obra com ênfase na qualidade do desempenho dos serviços prestados, oferecendo às construtoras, em especial àquelas de pequeno porte e prestadoras de serviço do setor, elementos padronizados de métodos de execução, verificação e registro da qualidade, como meio facilitador para obtenção de certificação ou qualificação com base nos requisitos de normas técnicas.

Público-alvo: Pequenas e médias construtoras que atuam no setor de edificações.

Estrutura e Conteúdo: o Guia organiza-se e estrutura-se a partir do mapeamento da tecnologia de produção de uma edificação residencial multifamiliar padrão ${ }^{47}$, contemplando as técnicas de execução de cada serviço, exceto as referentes aos serviços de infra-estrutura do edifício. As atividades pertencentes a cada método construtivo são identificadas, ordenadas e apresentadas na forma de fluxograma que estabelece a seqüência lógica para execução da edificação, considerando não apenas essa sequiência, mas também o modo simultâneo como as atividades e os métodos construtivos ocorrem na produção do edifício. Cada atividade identificada originou uma "Caixa de Serviço". O mapeamento integral dos métodos construtivos de uma edificação, com as respectivas atividades (Caixa de Serviço) inter-relacionadas, organizado na forma de um fluxograma, de modo a demonstrar

\footnotetext{
${ }^{46}$ Ressalta-se que apesar do Guia ser denominado como da qualidade dos "processos construtivos", a conceituação adotada no presente trabalho considera a definição dada por Sabbatini (1989) quanto a esse termo. Segundo o autor, processo construtivo é "um organizado e bem definido modo de se construir um edifício"..."um específico processo construtivo caracteriza-se pelo seu particular conjunto de métodos utilizados na construção da estrutura e das vedações do edifício (invólucro)". Já método construtivo, define o autor como sendo "um conjunto de técnicas construtivas interdependentes e adequadamente organizadas, empregado na construção de uma parte (subsistema ou elemento) de uma edificação". Portanto, entende-se que se trata, nesse caso, de acordo com tais definições, de métodos construtivos e não processos.

47 Prédio residencial, com cinco pavimentos sobre pilotis, estrutura convencional de concreto armado, alvenaria de vedação em bloco cerâmico. Instalações de água fria e quente, de incêndio, de esgoto sanitário, de águas pluviais, de gás, elétrica e especiais (telefone, interfone e pára-raios). Revestimentos externos de argamassa ou placa cerâmica, interno de gesso e em placa cerâmica. Pintura. Esquadrias de madeira, de alumínio e ferro. Pavimentação, interna e externa, de madeira, placa cerâmica, cimento e concreto. Forro de gesso, impermeabilização, cobertura com telha cerâmica ou de cimento amianto. Elevador e exaustão mecânica.
} 
todos os métodos de construção de uma obra como uma "linha de montagem", é uma tarefa dificultada pela quantidade de serviços envolvidos e interligações existentes entre esses na execução de um edifício. De modo a superar estes obstáculos e permitir que o processo de produção do edifício fosse analisado e visualizado, segmentou-se a edificação adotando-se, para tanto, o critério de agrupar espaços físicos que possuíssem características comuns em relação à execução da obra. Cada espaço físico agrupado originou um "Fluxograma do Setor". Os Fluxogramas dos Setores contemplam parte ou totalidade de diversos métodos construtivos de determinados serviços que são organizados e estruturados a partir das Caixas de Serviços. Ao agruparmos as Caixas de Serviços de acordo com o método construtivo de um serviço, por exemplo vedação em alvenaria, gerou-se o "Fluxograma do Bloco de Serviço". Com base na Caixa de Serviço, no Fluxograma Bloco de Serviço e no Fluxograma do Setor, segundo as informações cedidas, foi possível mapear a produção da edificação e estabelecer os fundamentos metodológicos para o desenvolvimento do trabalho. Mapeada a obra e definida a sequiência e a simultaneidade das atividades dos métodos construtivos, elaborou-se os instrumentos que permitirão assegurar o controle da qualidade dos serviços e do produto edifício, de modo integrado. O gerenciamento e o controle da qualidade da obra se efetua pelo Bloco de Serviços, que agrupa os seguintes documentos:

- IES - Instrução de Execução do Serviço

- IVS - Instrução de Verificação do Serviço

- RME - Relação de Material e Equipamento

- RVS - Registro de Verificação do Serviço

O IES e IVS são documentos técnicos de referência para a etapa de execução dos serviços, o RME é um documento para a área de suprimentos e o RVS é o documento onde se registra, por requisitos e ambientes da edificação, o desempenho de cada serviço da obra.

Por fim, Roberto Cunha salienta que todo o trabalho foi desenvolvido por profissionais vinculados ao setor produtivo, com uma visão mais operacional e que está sendo realizada a adequação, a padronização e, inclusive, a conceituação da terminologia empregada.

Além dos documentos já apresentados neste item 3.2, relativos aos referenciais tecnológicos nacionais, tem-se, de relevante para este estudo, o Manual de Controle de Obras e Serviços (MCOS), o qual é aplicado às obras da CDHU. Esse documento é analisado com mais detalhes no Capítulo 5, do presente trabalho, inclusive sob a ótica de sua aplicação prática. 
Conclui-se, do Capítulo 3, que os referenciais tecnológicos estrangeiros realmente são mais estruturados, sendo elaborados por entidades especializadas em seu desenvolvimento e atualização, que já trabalham com isso há anos. Alguns documentos estrangeiros contam mais com a participação dos agentes da cadeia produtiva da construção civil, enquanto outros parecem ser relativamente "impostos" quanto às suas exigências. De qualquer forma, o conhecimento de tais documentos, bem como das respectivas entidades, institutos ou organizações responsáveis pelos mesmos, serve para o nortear o desenvolvimento de um sistema de elaboração e consolidação de referenciais tecnológicos para o Brasil. Inclusive, ao se expor os documentos técnicos já desenvolvidos no país, é possível mostrar que a preocupação com esse tema realmente não é tão recente, porém algumas dificuldades de implementação de determinados documentos, por diversos motivos envolvidos na questão, ainda precisam ser superadas.

Após os estudos dos Documentos Técnicos Unificados e do Manual de Controle de Obras e Serviços, respectivamente apresentados nos Capítulos 4 e 5, como já citado anteriormente, realiza-se, no Capítulo 6, uma comparação e análise sintetizada entre os documentos estudados nesse capítulo, juntamente com outras discussões pertinentes. 


\section{Capítulo 4}

\section{Estudo dos documentos TÉCNICOS UNIFICAdos (DTU) - EXPERIÊNCIA DO CSTB - FRANÇA}

Além dos referenciais tecnológicos estrangeiros já vistos no Capítulo 3, apresenta-se, aqui, mais detalhadamente, o modelo de documentação técnica de referência existente na França: os chamados Documents Techniques Unifiés, traduzidos como Documentos Técnicos Unificados (DTU).

A escolha pelo estudo do modelo francês é feita, dentre outros motivos, devido ao alinhamento existente entre o Brasil e a França em alguns aspectos do setor da construção civil, apesar das diferenças sócio-econômicas. Por exemplo, de acordo com Cardoso (2003), existe uma semelhança entre os modos segundo os quais a questão dos sistemas de gestão da qualidade foi introduzida e vem sendo conduzida nesse setor, em ambos os países. Fato é que o Programa QUALIHAB implantado no Estado de São Paulo foi inspirado no modelo francês do Programa Qualification et Certification des Entreprises du Bâtiment (QUALIBAT), conforme foi visto no item 2.1.1 do Capítulo 2, sendo que ambos exigem a implementação de sistemas de gestão da qualidade baseado em referencial normativo da série de normas ISO 9000.

Um outro motivo que incentivou o estudo do DTU foi a existência de relações institucionais, de longa data, que o CSTB, organismo que tem por responsabilidade o gerenciamento desses documentos, tem com a EPUSP e o IPT, e também com o PBQP-H. Portanto, a troca já consolidada de experiências entre os pesquisadores e profissionais do Brasil e da França, facilitando, inclusive, o acesso a documentos de interesse sobre os DTU, também motivou a escolha pelo seu estudo de uma forma mais completa.

Assim, este capítulo consta de um estudo, cujo propósito é apresentar e descrever os DTU, bem como explorar o uso e a adaptação dos mesmos ao Brasil. Portanto, conforme item 1.5, trata-se de um estudo descritivo e exploratório, e a estratégia de pesquisa para seu desenvolvimento baseia-se em levantamento de dados a respeito de tais documentos e análise de arquivos.

Desse modo, obtém-se, com esse estudo, conhecimentos que enfocam o conceito e funcionamento dos DTU, no âmbito do setor da construção de edifícios na França. São obtidas informações do tipo: o que 
são os DTU, para que servem, o que contêm, quando e onde são utilizados, por quem podem ser empregados e como são elaborados. A análise dessas informações serve como embasamento das discussões feitas para a elaboração de referenciais tecnológicos brasileiros.

Para tanto, fez-se um levantamento de relatórios de pesquisadores e profissionais do setor da construção civil, representantes da EPUSP, IPT e PBQP-H, que participaram de estágios na França, no ano de 2000, para estudos relacionados ao assunto. Além disso, utilizou-se, como base, um relatório elaborado em 2002 pelo engenheiro Michel Bazin, responsável pela área de Normalização e Pareceres Técnicos do Centre Scientifique et Technique du Bâtiment $(\mathrm{CSTB})^{48}$ na França. Tal relatório, fruto da colaboração entre o CSTB e o PBQP-H, tem o objetivo de prestar uma assistência para concepção e elaboração de DTU no Brasil. Analisou-se, também, uma apresentação ministrada pelo eng. Michel Bazin, no Rio de Janeiro, nos dias 20, 21 e 22 de junho de 2002. Foi utilizado, ainda, o Manual do Redator de Normas Francesas - Documentos Técnicos Unificados (NF-DTU), manual este elaborado pela Commission Générale de Normalisation du Bâtiment (CGNorBât) ${ }^{49}$ da França, em 2001. Consultou-se, adicionalmente, o documento publicado pela ANTAC, em 2003, a respeito da "Cooperação Brasil-França", tratada no Seminário Cidades, Ciência e Tecnologia. Este documento possui um capítulo sobre o estado-da-arte na França, baseado em informações de profissionais que atuam no CSTB (Robert Copé e Michel Bazin). Finalmente, pesquisou-se a Enciclopédia de regras técnicas para a construção civil da França (Encyclopedie des règres techniques du bâtiment), elaborada pelo CSTB e Association Française de Normalisation (AFNOR) ${ }^{50}$ e disponível em CDROM, bem como alguns modelos dos próprios documentos encontrados em bibliotecas.

Nesse capítulo, além da apresentação e análise dos documentos propriamente ditos, faz-se uma contextualização dos mesmos, citando-se algumas características peculiares do setor da construção francesa de edifícios, no qual estão inseridos os DTU. Tais informações devem ser consideradas quando se tratar da adaptação dos conceitos desse tipo de documento técnico de um país estrangeiro para o Brasil.

\footnotetext{
${ }^{48}$ A título de curiosidade, o CSTB (traduzido como: Centro Científico e Tecnológico de Edificações) foi fundado em 1947, sendo hoje uma instituição pública com caráter comercial e industrial, sem fins lucrativos, que possui quatro missões: pesquisa aplicada à construção civil; consultoria científica e tecnológica; avaliação técnica de produtos inovadores e certificação de produtos convencionais (possui 40 laboratórios de ensaios); e disseminação do conhecimento, cursos de formação continuada e publicações técnicas. (Informações obtidas na Palestra: "Certificações Francesas para Agentes do Setor da Construção Civil e para Empreendimentos", ministrada pelo Eng. Patrick Nossent, do CSTB, França. Evento realizado no dia 8 de dezembro de 2005, na Escola Politécnica da USP.)

49 Tradução: Comissão Geral de Normalização da Construção.

${ }^{50}$ Tradução: Associação Francesa de Normalização. A AFNOR é equivalente à ABNT no Brasil.
} 


\subsection{Contextualização dos DTU}

$\mathrm{Na}$ legislação francesa que regulamenta a atividade da construção local tem-se que é o Estado quem regula o direito de construir e de demolir. Pode-se pensar que para o Brasil isto também ocorre; entretanto, é importante ressaltar que na França existe uma figura que não se tem no Brasil: o seguroconstrução. Seguro este, de caráter obrigatório, que faz com que sempre exista um "garantidor" do produto edifício, mesmo nos casos em que o empreendedor ou a construtora "desapareça" do mercado, porque, em última instância, há a seguradora. Portanto, a finalidade do seguro-construção, de acordo com Weber (2000), é dar garantias a todos os responsáveis pelo produto edificação. Dos fornecedores ao empreendedor, passando pelos projetistas, construtores e subempreiteras, escritórios de controle, todos necessitam garantir-se mediante apólices de seguro. Essas apólices de seguro são calculadas em função do risco que a atividade de cada um pode introduzir no produto final, a edificação, e do comportamento histórico do agente.

Nesse contexto, é necessária a realização de um controle técnico rigoroso de todo o processo produtivo, assegurando que todos os agentes têm desempenhado como previsto ao longo do empreendimento, garantindo a entrega da obra segundo as especificações e minimizando a ocorrência de sinistros. Todavia, para que haja tal controle, é necessário que se identifique com precisão o que se está controlando e com que referencial técnico. E é aí que a normalização e todos os seus instrumentos e procedimentos ganham sentido, inclusive os DTU. Com relação a isso, a ANTAC (2003) afirma que a existência de tais ferramentas de capitalização coletivas na França, ou seja, as normas, os DTU, os Conselhos Técnicos, etc., complementadas pelas declarações de certificação de conformidade dos produtos, tornam não somente possível mas também crível a introdução generalizada das medidas de seguro da qualidade e sua certificação dentro do setor complexo da concepção e execução dos edifícios.

Salienta-se, aqui, outros aspectos relativos ao controle exercido no âmbito da construção civil francesa, realizado de forma efetiva e rigorosa, o que, em geral, não se observa, dessa maneira, no Brasil. Na França, o controle é exercido nos empreendimentos desde 1926, sendo que até 1978 restringia-se a uma atividade de avaliação de riscos para as seguradoras. Segundo Mitidieri Filho (2000), após 1978, a atividade de controle passou a ser obrigatória para alguns tipos de edifícios, públicos em geral que comportam acima de um determinado número de pessoas, edifícios altos ou mais complexos. $\mathrm{O}$ autor cita, ainda, que excetuando-se as residências unifamiliares ${ }^{51}$, o controle tem sido exercido em $90 \%$ das construções, dividido entre controle obrigatório (45\%) e voluntário (45\%),

\footnotetext{
${ }^{51}$ Para elas, o controle ainda é incipiente, em torno de $1 \%$ das casas.
} 
sendo que apenas $10 \%$ das construções não são controladas. Portanto, mesmo nas construções onde é facultativo, percebe-se que o controle é uma atividade significativa, iniciando-se no planejamento do empreendimento e terminando no recebimento da obra. Ao longo da obra, o controle é baseado em vistorias periódicas, verificando-se inclusive a existência e o atendimento aos DTU e Avis Techniques $(\mathrm{ATEC})^{52}$ para serviços e produtos. Antes do recebimento da obra, o "controlador técnico" (contrôleur technique) emite um relatório, abordando aspectos como solidez, segurança ao fogo, acústica, instalações, isolação térmica etc., sendo que os dois primeiros itens são obrigatórios e devem ser encaminhados à seguradora do empreendimento.

É importante destacar que os DTU, atualmente, estão inseridos na normalização técnica da França, como será explicitado no item relativo ao 'histórico' de tais documentos (item 4.3), e que, de acordo com Mitidieri Filho (2000), a normalização francesa não constitui um processo burocrático, para criar regras, mas sim leva à consolidação, ou mesmo ao desenvolvimento da tecnologia do país.

O autor cita que além das normas francesas homologadas, que incluem os DTU, exitem outros documentos técnicos normativos disponíveis como: fascículos de informações, contendo recomendações técnicas e não prescrições; especificações técnicas de sindicatos, por exemplo; e os ATEC, ou referências técnicas, já apresentados anteriormente. Quanto à inserção dos DTU sob o ponto de vista de conteúdo das normas técnicas, tem-se que estes enquadram-se no tipo 'especificações técnicas de serviços' (execução). Existem ainda outros tipos de normas técnicas, como as fundamentais (a exemplo da NB 0, no Brasil), as de métodos de ensaios, as especificações técnicas de produtos, bem como as normas de organização, a exemplo da ISO 9000, da norma que define a missão dos controladores técnicos e da norma que define as relações entre o construtor e o empreendedor (NF P 03001 - Cahiers des Clauses Administratitives ${ }^{53}$ ).

Entretanto, ressalta-se que, na França, tais documentos normativos são de uso voluntário, sendo somente obrigatório o cumprimento das leis e regulamentos. Mesmo assim, percebe-se que o Sistema DTU está efetivamente inserido e consolidado nas atividades do setor da construção civil na França, principalmente como conseqüência da obrigatoriedade do seguro-garantia, este sim exigido por lei.

\footnotetext{
52 Os ATEC são equivalentes às chamadas "Referências Técnicas" no Brasil, elaboradas para produtos ainda não normalizados. Na França, se houver algum produto não normalizado ou inovador o controlador pode solicitar a apresentação de um ATEC, caso ainda não exista. O controlador também verifica a existência de certificado de conformidade para produtos convencionais e se tais produtos atendem ao uso previsto.

${ }^{53}$ NF P 03 001- Cahiers des Clauses Administratifis. Tradução: Caderno de Cláusulas Administrativas. Essa norma prevê que na ausência de cláusulas técnicas especiais no contrato específico passarão a valer os DTU e ATEC, para efeitos contratuais (WEBER, 2000).
} 
O acesso aos DTU pode ser feito por meio do CD-Reef, o qual se trata de uma enciclopédia digital com regras técnicas da construção civil da França. Este CD-ROM é atualizado a cada seis meses, aproximadamente, e ainda contém Normas Francesas, Avis Techniques, textos legislativos e regulamentares, documentos de regras de cálculos, dentre outros. Todos esses documentos que foram publicados até a data de 15 de março de 2005 estão disponíveis na atual versão do CD-Reef, de setembro de 2005 (CSTB, 2005). A seguir, são detalhados os Documentos Técnicos Unificados.

\subsection{Conceituação dos DTU}

O Sistema DTU é composto por uma série de documentos que registram as boas práticas profissionais para a execução dos mais diferentes serviços para a construção de edifícios na França, com destaque para os envolvidos na execução. Atualmente, grande parte dos DTU constitui-se em Normas Francesas (NF), sendo denominados NF-DTU. Esses documentos são compostos por três partes, nem sempre todas presentes nos documentos, são elas: os Cahier des Clauses Techniques ${ }^{54}$ (CCT); os Cahier des Clauses administratives Spéciales ${ }^{55}$ (CCS), esses dois relativos à execução dos serviços de determinada obra; e os Guias, principalmente aqueles para adaptação das obras e serviços às condições externas.

O Sistema DTU representa o conhecimento tecnológico de toda a construção civil na França, estabelecendo as regras para a execução dos diferentes serviços envolvidos numa obra de edifícios, ou seja, "formalizando" os diferentes métodos construtivos ou mesmo processos, conforme o caso (CARDOSO, 2000).

De acordo com Weber (2000), os DTU formam a base das especificações técnicas da maioria dos contratos entre os diversos agentes da cadeia produtiva da construção, estando todos associados a uma norma que fornece um modelo para a redação desses contratos.

Os DTU não são obrigatórios; porém, são empregados largamente, pois definem os procedimentos de técnicas executivas convencionais, balizando o mercado. A seguradora normalmente "recomenda" a adoção do DTU; caso contrário, o prêmio do seguro é maior, afirma Mitidieri Filho (2000).

De acordo com Cardoso (2000), desde que o Sistema DTU foi criado, um de seus papéis essenciais é o de servir de referência para vários tipos de "contratos": entre o cliente e as empresas contratadas, entre essas e as seguradoras, etc. Mesmo não sendo de uso obrigatório, acabam sendo efetivamente

\footnotetext{
${ }^{54}$ CCT - Caderno de Cláusulas Técnicas de execução das obras.

${ }^{55}$ CCS - Caderno de Cláusulas administrativas Especiais aos contratos do escopo de aplicação.
} 
praticados pelas empresas, fazendo parte dos "hábitos", ou seja, do dia-a-dia das empresas e dos próprios operários.

Segundo Barros (2000), ninguém discute, apenas utiliza as informações contidas em tais documentos. Deve-se ressaltar que a aplicação dos DTU é verificada e relatada pelo controlador técnico para o empreendedor e as seguradoras. $\mathrm{O}$ fato de um procedimento de execução seguir os preceitos de um DTU torna-o crível para as gerenciadoras (controladoras) e facilita (e até possivelmente reduz) a necessidade de novos prêmios de seguro ou mesmo de controles.

A fim de se evitar a necessidade de se redefinir de maneira contratual, detalhadamente, para cada projeto e cada contrato, tudo o que se espera do empreendimento, parece mais útil fazer isso de maneira coletiva e consensual para tudo aquilo que se apresenta repetitivamente em todos os projetos e dar a essas convenções um caráter de Cadernos de Encargos Padrão ao qual todo contrato poderia recorrer, seja na sua totalidade ou parcialmente, seja com ou sem modificações.

Segundo Bazin (2002), um DTU “não deve procurar ser”:

- "um curso de técnicas de construção: de fato, seu aspecto essencialmente contratual é incompatível com desenvolvimentos pedagógicos; porém, a existência de um DTU pode servir de suporte para documentos pedagógicos. O DTU não pode conter disposições sob forma de recomendações que não sejam úteis sob o ponto de vista contratual. Na prática, o momento em que se torna útil recorrer a tais recomendações, estas são dispostas nos comentários não contratuais ou nos anexos, igualmente não contratuais.

- Uma descrição do 'saber fazer' ou dos meios empregados pela empresa para a realização das obras / serviços: a escolha dos meios, dos métodos internos, a experiência e o 'saber fazer' de uma empresa fazem parte do seu patrimônio e da sua capacidade competitiva. O objetivo do DTU não é o de definir meios, mas as qualidades que se exige da obra terminada. Quando essas qualidades são facilmente verificadas na obra, torna-se inútil se fazer referência aos meios pelos quais se atingirá essa qualidade. Exemplo: para um serviço / obra de alvenaria pode-se exigir características de prumo. O DTU pode especificar que o desvio de prumo não deverá ser superior a x centímetros por andar ou pela altura global; em compensação não será especificado o meio pelo qual o operário atingirá esse objetivo (que ele utilize um fio de prumo ou o raio laser). Entretanto, quando a conformidade final de uma obra não pode ser simplesmente constatada ou verificada por uma inspeção de recebimento na obra, mas que se possa identificar as condições que são indispensáveis ao bom resultado da obra, essas condições podem ser lembradas pelo DTU e assim impostas contratualmente pelo 
empreendedor. Por exemplo: a molhagem das alvenarias antes da execução dos revestimentos de argamassa tradicionais.

- Um Manual de garantia da qualidade: tal manual diz respeito a uma dada organização e aos processos que uma empresa construtora implementa para o seu sistema de produção; o DTU não é um meio para tratar disso. Na medida em que um DTU especifica de maneira padronizada uma categoria de serviço / obra repetitivo, ele pode servir de base para a definição de procedimentos de garantia da qualidade das empresas construtoras envolvidas com esse tipo de serviço / obra. Nada proíbe a introdução nos documentos do tipo DTU de certas referências destinadas a identificar diferentes pontos chaves a se introduzir num sistema de garantia da qualidade visando estabelecer a conformidade com relação ao DTU.

- Um tratado exaustivo de regras aplicáveis a todo tipo de empreendimento: uma tal orientação vai de encontro a eficácia requerida e não se coaduna com a idéia de se ter um escopo muitas vezes limitado para o qual um consenso dentre as profissões pode ser legitimamente estabelecido. Fora desse escopo, é conveniente que se indique a necessidade de tratar contratualmente caso a caso as disposições a serem adotadas no empreendimento".

Além do caráter de serem unificados, segundo a CGNorBât (2001), os DTU possibilitaram um grande avanço ao terem sido estabelecidos de forma paritária. Destinados a serem incorporados nos contratos da construção, devem ser discutidos e aceitos pelas partes interessadas: empresas construtoras e fornecedores, clientes representados pelos seus arquitetos e escritórios de controle; o CSTB era originalmente o fomentador e o "árbitro" do processo.

\subsection{Histórico e Evolução dos DTU}

A idéia de se elaborar Cadernos de Encargos padrões, segundo Bazin (2002), tem sua origem na constatação de que, mesmo se cada construção é única e original, um certo número de escolhas, decisões e disposições decorrentes e comumente empregadas, desde que digam respeito a produtos e tecnologias consolidadas e ao projeto considerado, apresentam um caráter repetitivo, independentemente dos agentes específicos de um dado empreendimento.

A partir daí, existe um forte interesse de reunir o conjunto dos elementos susceptíveis de apresentarem esse caráter repetitivo, de maneira a se poder se referir de forma padronizada a tal conjunto, por ocasião do estabelecimento das especificações do projeto, e a permitir se concentrar a atenção na parte das especificações que restam particulares ao empreendimento considerado ou à equipe de agentes que nele atuam. Na prática, tais cadernos de encargos padrões podem ser elaborados, para em seguida 
serem adaptados caso a caso, conforme o contrato, por qualquer organização, por conta própria e segundo a necessidade de cada um.

De acordo com Bazin (2002), este foi o caso que ocorreu na França antes do surgimento dos DTU, quando algumas entidades de profissionais como a dos arquitetos ou diferentes sindicatos de construtores ou ainda empreendedores privados como os ligados às habitações de aluguel social ${ }^{56}$ ou à Educação Nacional, publicaram documentos dessa natureza. Tal profusão de textos tendia a gerar conflitos entre os agentes da cadeia produtiva.

A originalidade da abordagem DTU foi a de propor a essas diferentes entidades que renunciassem a proporem, cada uma por si, cadernos de encargos padrões próprios, passando, em comum acordo, a um processo de capitalização da experiência de cada um e unificando esse procedimento de redação.

Nesse contexto, em 1957, surge o DTU por meio de um processo de consolidação dos "códigos de práticas" que eram usados por contratantes de obras, como as empresas de habitação para aluguel social, arquitetos, empresas de controle tecnológico, seguradoras e sindicato de construtoras. Coube ao CSTB o papel de coordenar todo esse trabalho, tarefa que exerce até hoje; de modo que se tivesse um documento comum, validado por todos os agentes da construção e, portanto, aceito pelos mesmos.

Desse modo, um contrato de execução de uma obra ou de um serviço na França contém, geralmente, duas categorias de cláusulas técnicas:

- cláusulas técnicas gerais: referem-se a um conjunto de documentos de especificações de caráter repetitivo (DTU);

- cláusulas técnicas particulares: descrevem as particularidades do empreendimento (seja por exceção frente às especificações gerais, seja por adição em se tratando de aspectos não contidos nas especificações gerais).

A partir de 1993, os DTU passaram a ter status de norma técnica, sendo incorporados pela AFNOR, por causa da unificação européia (NF-DTU). Atualmente, os documentos são apresentados com uma numeração relativa à norma francesa, mas guardam também o seu código referenciado como DTU (CARDOSO, 2000).

\footnotetext{
${ }^{56}$ Tradução do termo em francês: Habitation à Loyer Modéré (HLM).
} 
Segundo a CGNorBât (2001), os DTU acabaram se impondo após 40 anos como documentos técnicos incontornáveis dos contratos de edificações devido a duas de suas qualidades: unidade e caráter paritário, às quais se acrescenta a qualidade das redações de seus textos.

Percebe-se, portanto, que a criação prévia de documentos técnicos de referência não normativos, provenientes da compatibilização de procedimentos exigidos por diferentes agentes da cadeia produtiva da construção de edifícios local ou de práticas já consolidadas em diversas empresas, contribuiu significativamente para que o consenso entre os profissionais do setor fosse alcançado, culminando na aplicação dos DTU com caráter unificado a nível nacional, apesar da não obrigatoriedade de seu uso.

\subsection{Objetivos dos DTU}

Segundo a CGNorBât (2001), em primeiro lugar, os DTU são documentos padrão destinados a serem inseridos nos editais de escolha de empresas construtoras em obras de edifícios. Em segundo lugar, são documentos destinados a serem inseridos nos contratos. Isso quer dizer que os CCS farão parte das cláusulas administrativas do contrato e que os CCT dos documentos técnicos do contrato, o que reduz, consideravelmente, os “documentos técnicos particulares", chegando até mesmo a suprimi-los.

Os objetivos das cláusulas existentes nos DTU são, segundo a CGNorBât (2001), os seguintes:

- “caderno de Cláusulas Técnicas (CCT): tem o objetivo de lembrar algumas prescrições técnicas de execução, não muito conhecidas ou freqüentemente desrespeitadas, a fim de garantir que a obra / serviço atenda o melhor possível às expectativas do cliente, evitando-se problemas danosos às duas partes. Somente de maneira indireta é que tais documentos são didáticos, ou seja, não foram escritos como cursos de ensinamento técnico.

- Caderno de Cláusulas administrativas Especiais (CCS): são destinados a definir as obrigações mútuas entre as partes, assim como os deveres para com os outros participantes.

- Guias: funcionam, principalmente, como regras de concepção de detalhes de execução e exemplos de solução; regras de adaptação ao terreno e conselhos aos redatores dos documentos particulares do contrato. Podem ter valor normativo ou informativo".

Os CCT servem de texto base para o controlador técnico. E como tais regras foram estabelecidas em comum acordo e com a participação dos controladores técnicos, dificilmente eles as contestarão. Já os CCS serão inseridos nas cláusulas administrativas do contrato, com as vantagens decorrentes da redação comum e da unificação. Caso se queiram impor cláusulas diferentes das do CCS, elas devem 
aparecer nos documentos como exceções ao CCS, sendo, portanto, facilmente identificadas. Logicamente, se recorrerá ao CCT e ao CCS em caso de conflito entre as partes, já que eles são parte do contrato.

Pode-se perceber ainda que, de acordo com o conceito dos DTU (item 4.2), estes também podem ser considerados 'códigos de práticas', conforme definição vista no item 3.1 deste trabalho. Assim, têm o objetivo de registrar as práticas profissionais que contribuem para a melhoria da qualidade e da produtividade da construção de edifícios na França, visando a satisfazer as exigências de desempenho dos edifícios e colaborando, inclusive, com a disseminação do conhecimento local.

\subsection{Natureza e status dos DTU}

A natureza primeira e essencial de um DTU, segundo Bazin (2002), é a de constituir um elemento de contrato entre a organização que encomenda a obra de edificação e aquela que a realiza. Para tanto, os DTU adotam uma estruturação por categorias de obras / serviços e segundo as diferentes tecnologias normalmente utilizadas para realizá-las.

Um DTU não pretende ser totalmente exaustivo, pois cada empreendimento poderá complementá-lo por meio das disposições particulares da obra considerada. Sua natureza estritamente 'contratual' e a idéia da indispensável presença no contrato de outros elementos específicos ao empreendimento considerado, conferem ao DTU um caráter eminentemente voluntário. É devido a tal natureza, além de outras considerações mais diretamente ligadas ao contexto francês, que por muito tempo hesitou-se quanto a conferir a estes cadernos de encargos padrões o status de norma (BAZIN, 2002).

O autor esclarece que, efetivamente, ainda que as normas, na França, sejam por princípio de uso voluntário, uma vez adotadas elas assumem um caráter relativamente restritivo, ao menos no entendimento que têm os seus usuários. Assim, o DTU não pretende impor o que convém se fazer, mas descreve soluções consolidadas que são reconhecidamente satisfatórias. O DTU não proíbe uma outra solução, que pode ser descrita nas especificações particulares de um contrato.

\subsection{Procedimentos para elaboração de um DTU}

A produção dos DTU, segundo Cardoso (2000), desde sempre foi comandada pelo CSTB (início em 1957), que é quem normalmente fornece o profissional que prepara o seu texto de referência, assim como o coordenador do respectivo comitê de normalização. 
Os DTU são atualmente registrados na AFNOR, passando por um processo de votação, como no caso da norma tradicional. Esse processo todo é gerenciado pelo CSTB, por delegação da AFNOR.

Assim, os procedimentos para elaboração de um DTU são semelhantes aos utilizados para uma norma comum, sendo apenas realizados quando há consenso entre os agentes envolvidos. Em relação aos procedimentos adotados pela AFNOR para a elaboração de normas técnicas, Barros (2000) destaca que estes estão fundamentados na existência de comissões, das quais participam os diferentes agentes do setor, tais como: fabricantes, representantes do Estado, empresas de montagem de um determinado produto, técnicos como arquitetos e engenheiros, consumidores, laboratórios (dentre eles, o CSTB), e toda a participação dos membros, assim como no Brasil, é voluntária.

Segundo a CGNorBât (2001), pelo fato de os DTU terem se tornado normas francesas, seus redatores devem respeitar as regras de apresentação das normas, enunciadas no fascículo de documentação FDX 00-001 "Normas francesas - Regras para redação e apresentação - Conselhos práticos". Este documento oferece a flexibilidade necessária para redigir as prescrições segundo uma forma conveniente à execução das obras e à finalidade das NF-DTU. O redator, qualquer que seja sua origem, deve levar em conta que ele redige um documento prescritivo que o empreendedor impõe no seu contrato.

\subsection{Estrutura e Conteúdo de um DTU}

Um DTU, segundo a CGNorBât (2001), deve ter um campo de aplicação bem definido (em geral, delimitado aos serviços fornecidos por um contratado apenas); as cláusulas técnicas e próprias à organização do contrato e as cláusulas administrativas quanto às relações entre os agentes devem, em geral, estar separadas.

A ênfase para o presente estudo é dada aos Cadernos de Cláusulas Técnicas, destacando-se sua estrutura e conteúdo, já que as CCS e os Guias têm objetivos que não interessam diretamente aqui. Nas CCT só devem estar presentes prescrições para as quais o empreendedor poderá verificar a aplicação e, da mesma maneira, que a empresa poderá verificar que as tenha atendido satisfatoriamente. Portanto, as prescrições deverão ser precisas, quantificáveis e passíveis de serem verificadas por meios claramente definidos.

A CGNorBât (2001) salienta que um CCT não deverá ultrapassar 40 páginas, incluindo os anexos, pois documentos muito longos, segundo tal Comissão, são "mal lidos e, portanto, mal conhecidos e pouco aplicados". 
A estrutura do Caderno de Cláusulas Técnicas de um DTU deve ser organizada conforme um planopadrão, relativamente flexível. A seguir, a Figura 9 mostra um modelo de estrutura típico.

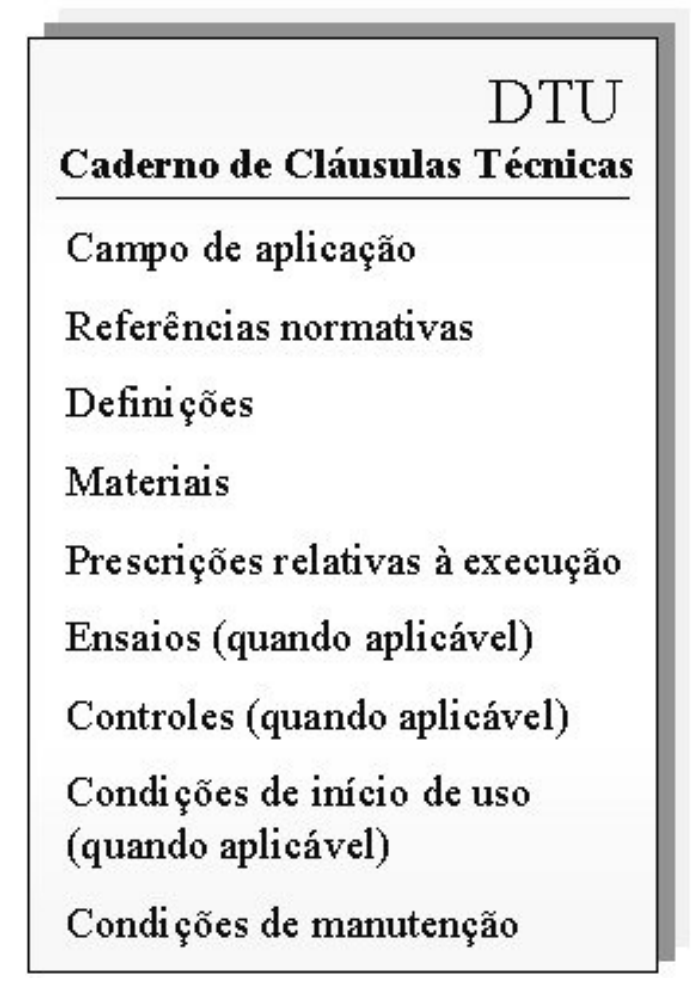

Figura 9 - Modelo de estrutura do Caderno de Cláusulas Técnicas de um DTU. (Fonte:CGNorBât, 2001)

O conteúdo de cada item citado na estrutura do documento é apresentado na seqüência, tomando como base o Manual do Redator de NF-DTU, elaborado em 2001 pela Comissão Geral de Normalização da Construção na França: a CGNorBât.

\subsubsection{Artigo 1: Campo de aplicação}

Este item trata da definição do objeto e do escopo de aplicação do DTU, podendo ser subdividido em dois artigos: um para o objeto e outro para o escopo de aplicação. As obras ou serviços para os quais se aplicam as prescrições técnicas do DTU são aqui definidos sem qualquer ambigüidade. Caso haja qualquer restrição de aplicação, esta é citada nesse item. O campo de aplicação não pode ser muito abrangente, sob a pena de incluir obras ou serviços muito diferentes como sendo objeto de prescrições comuns. 


\subsubsection{Artigo 2: Referências normativas}

Nesse item são enumerados, de forma exaustiva, todos os documentos normativos aos quais se faz referência no DTU. Esses documentos são designados pelo seu título e sua referência, sem indicação de data de publicação ou de validade, visando evitar que o texto do DTU torne-se obsoleto desde a primeira modificação de um dos textos referenciados.

\subsubsection{Artigo 3: Definições}

Apresentam-se, neste item, as definições dos termos técnicos específicos para o tipo de obra ou serviço considerado e que ainda não são definidos numa norma mais geral de terminologia. Caso já exista uma definição, esta é citada de forma idêntica e contendo a sua origem. Porém, evita-se definir palavras que existem nos dicionários comuns.

Todas as definições são feitas de forma específica, evitando-se que haja 'confusão' com a palavra empregada no seu sentido geral. Além disso, não são definidas palavras ou expressões que não apareçam no DTU, bem como não estão incluídas as prescrições relativas à natureza dos produtos utilizados ou à sua aplicação. Essas prescrições constam dos artigos "Materiais" ou "Prescrições relativas à execução".

\subsubsection{Artigo 4: Materiais}

Neste item são apresentados todos os materiais que são objetos de uma prescrição de uso no DTU, com a indicação dos documentos normativos que dizem respeito a eles.

Caso algum tipo de material não conste em normas técnicas, mas seja objeto de um ATEC, este deve ser citado, incluindo o período de validade para o emprego do mesmo. Agora, caso o material não esteja incluso na normalização e nem no ATEC, de modo excepcional, deve-se apresentar uma descrição precisa dos ensaios que permitirão aceitar ou rejeitar o seu fornecimento. O critério de aceitação ou rejeição dos materiais não pode ser vago, como, por exemplo, "o material deve ser durável”.

A CGNorBât (2001) ressalta que a definição de 'componentes' é distinta da de 'materiais', sendo conveniente apresentá-los, caso necessário, em um item específico denominado: "Componentes". Segundo a ISO 6707-1(P 00-001) apud CGNorBât (2001), tem-se a seguinte definição de 'componentes': "produtos fabricados como unidades distintas para desempenhar uma (ou várias) função(ões) específica(s)". Assim, no item relativo a estes, pode-se falar em 'desempenho de 
componentes', conceito definido pela NF P 05-300 como "comportamento de um produto em função de sua utilização".

\subsubsection{Artigo 5: Prescrições relativas à execução}

Este item compõe o "núcleo" do DTU. Como já foi citado anteriormente, o DTU não é um curso de construção, sendo direcionado aos profissionais que já conhecem o seu ofício. Portanto, as prescrições de execução devem essencialmente tratar dos pontos usualmente mal abordados na prática, num dado momento e contexto.

O DTU descreve a execução de uma obra ou serviço tradicional, visando à sua qualidade. Porém, o desempenho exigido para tal obra ou serviço não é indicado neste item, já que consta de regulamento e de leis específicas (segurança, saúde, acessibilidade, consumo energético, conforto, etc.). A linguagem utilizada é sempre clara e precisa, do tipo: "é necessário", "deve-se", "é proibido", e não: "dever-seia", "pode-se", "geralmente".

Em relação à qualificação da mão-de-obra, ou seja, dos que vão executar a obra ou serviço, a posição francesa, em especial no Comitê Europeu de Normalização (CEN), é a de que não se deve fixar a qualificação dos intervenientes nas prescrições técnicas.

Quando a obra ou serviço objeto do DTU for composta por vários subserviços independentes, impõese subdividir o artigo 5 em 5.1, 5.2, etc., cada um relativo a um subserviço.

Pode ocorrer que um serviço complexo seja realizado por várias empresas. Assim, pode ser conveniente se ter um só DTU, que figurará nos contratos celebrados com essas diversas empresas. Nesse caso, além da clara exposição da situação no CCS, deve-se tomar o cuidado de indicar no CCT qual a empresa encarregada de cada parte do serviço.

Deve-se evitar a aceitação dos serviços ou obras de uma empresa por outra que atua seqüencialmente no canteiro. A CGNorBât (2001) chama a atenção para o fato de que, na França, a aceitação é um ato jurídico, definido no Código Civil e sobre a qual somente o empreendedor pode se pronunciar. Segundo a Comissão, a solução ao problema que se quer resolver por meio da aceitação é a constatação de que as obras ou serviços precedentes executadas por outras empresas respondem às condições previstas pelo DTU para a execução dos serviços subseqüentes. É conveniente, portanto, definir no DTU o que deve ser feito, se tais condições não forem atingidas.

Enfim, se o CCT propuser várias maneiras para a execução dos serviços ou obras, deve-se prever que os documentos particulares possam ter imposto uma dentre elas. Afim de que as propostas das 
empresas sejam fundamentadas nas mesmas bases, os aspectos de projeto relativos a cada modo de execução devem ser claros e completos.

\subsubsection{Artigo 6: Ensaios (quando aplicável)}

Esse artigo só deve ser redigido caso seja necessário se prescrever ensaios que não sejam objetos de nenhuma norma.

Caso existam normas, estas são referenciadas nos artigos "Materiais" ou "Prescrições relativas à execução", no caso da definição das propriedades do material e, além disso, a norma de ensaio é citada no artigo "Referências normativas".

Caso não haja uma norma que defina o ensaio, essa definição é dada neste item. Caso esta definição seja muito extensa, pode-se, excepcionalmente, colocá-la num anexo normativo do DTU.

\subsubsection{Artigo 7: Controles (quando aplicável)}

Este item trata de verificações, durante a execução ou no recebimento, da conformidade das obras ou serviços a determinadas especificações do artigo "Prescrições relativas à execução".

Consta daqui a relação dos controles e verificações a serem exercidos. De maneira geral, destaca a CGNorBât (2001) que "as orientações dadas para o caso do artigo 5 são aqui válidas".

\subsubsection{Artigo 8: Condições de início de uso (quando aplicável)}

As prescrições desse item são de mesma natureza que as do item precedente (controles), podendo-se de modo inequívoco reuni-las num mesmo artigo.

\subsubsection{Artigo 9: Condições de uso normal e de manutenção}

Segundo a CGNorBât (2001), não se trata de impor automaticamente ao prestador do serviço de execução (construtora ou empresa especializada) a responsabilidade pela manutenção ainda que o empreendedor tenha assinado um contrato de execução e de manutenção por determinados anos de duração. Trata-se, neste item, de chamar a atenção para o fato de que as obras ou os serviços executados em conformidade com as prescrições dos artigos precedentes são somente satisfatórios, ou seja, oferecem a durabilidade e os outros desempenhos que se espera deles, se o empreendedor os 
mantiver segundo as indicações prescritas neste artigo e se ele os usa respeitando determinadas regras. Para tanto, são possíveis duas alternativas:

- redigir um documento específico para a obra ou serviço objeto do CCT descrevendo as condições de uso e manutenção normais. Esse documento pode compor um artigo do CCT ou um anexo ou Guia do mesmo, enumerando as exigências de manutenção com a precisão necessária à determinação da responsabilidade ou não responsabilidade do executor em caso de patologias; ou

- fazer referência explícita num artigo do CCT ou em anexo a documentos gerais ao fascículo de documentação P 05-100 “Condições de uso normal de uma habitação" que pode servir, com as devidas modificações, a outros tipos de edificações. Essa alternativa é a menos recomendada.

A estrutura e o conteúdo dos Cadernos de Cláusulas Administrativas Especiais não se encontram no escopo do presente estudo.

Percebe-se, após a apresentação da estrutura e do conteúdo das cláusulas técnicas do DTU, que tais documentos abordam referenciais tecnológicos de procedimentos de execução e podem incluir referenciais tecnológicos de controle do processo, quando for o caso, bem como de especificação do produto, contemplado geralmente em anexo como dados para a elaboração de projetos, por exemplo. Além disso, incluem referências para a manutenção dos edifícios.

\subsection{Vantagens e Desvantagens do Sistema DTU}

Segundo Cardoso (2000), o Sistema DTU facilita muito o trabalho de todos os agentes da cadeia produtiva, sejam contratantes, projetistas ou executores. Por exemplo, nos contratos, são estabelecidos que para a execução de um dado serviço devem ser obedecidas os DTU que neles são enumerados.

Os DTU são elementos essenciais de referência para as seguradoras e empresas de controle tecnológico, pois sua aplicação minimiza a possibilidade do aparecimento de patologias e potencializa a obtenção dos requisitos de desempenho esperados.

Uma das principais virtudes dessas coleções de textos, de acordo com Weber (2000), é que elas representam o consenso sobre determinadas práticas desenvolvidas por todos os agentes do setor da construção. São eles mesmos que periodicamente desenvolvem um esforço considerável em termos de organização e de mobilização de efetivos para mantê-los atualizados. Por ocasião de um contrato entre cliente e projetista, entre construtores e os diversos subempreiteros é necessário definir com precisão o conjunto dos serviços a serem executados. Segundo a autora, a falta de especificação quanto à natureza 
dos serviços aumenta as possibilidades de incompreensão entre as partes contratadas, com riscos para a qualidade de execução das obras, gerando conflitos entre os agentes (natureza dos serviços, atribuições de tarefas, qualidade dos materiais, etc.). A existência dos DTU validados pelo consenso de todas as partes envolvidas permite a inclusão de cláusulas contratuais típicas para todos os serviços por simples referência aos DTU, detalhando apenas os serviços não convencionais ou particulares para uma determinada edificação.

Segundo Bazin (2002), os DTU apresentam as seguintes vantagens:

- “do ponto de vista da produtividade: simplificam, consideravelmente, a preparação dos projetos, o processo de escolha das empresas construtoras e os controles do empreendimento; e

- do ponto de vista da qualidade: a existência de referencias tecnológicos precisos e que podem ser usados sistematicamente permite otimizar inúmeros fatores:

- a indústria de materiais e componentes passa a dispor de indicações precisas sobre os níveis de desempenho requeridos para as obras; isso facilita a melhoria da qualidade dos produtos, sua normalização e sua certificação de conformidade;

- na etapa de projeto, levam a um nível homogêneo de prescrições sobre seus pontos essenciais, a partir de exigências consolidadas e aprovadas por todos os agentes;

- no âmbito das empresas construtoras, constituem uma base comum a partir da qual pode-se desenvolver plenamente um "saber fazer", disposições perenes voltadas à garantia da qualidade, métodos de orçamentação mais precisos e mais rápidos, próprios a cada empresa;

- para as instituições de formação profissional, formam uma base técnica a partir da qual se articulam os diferentes programas pedagógicos;

- para a comunicação entre os agentes, oferecem uma linguagem comum permitindo limitar os riscos de equívocos ou incompreensões".

Desse modo, o DTU constitui ao mesmo tempo uma ferramenta de produtividade, qualidade e simplificação das relações entre os agentes da construção civil.

Ainda quanto às vantagens, a ANTAC (2003) cita que a elaboração dos DTU consolida o essencial das discussões e formulações que deveriam necessariamente ser feitas em cada projeto individual, caso não houvesse tais documentos. Assim, apesar de os DTU não conseguirem regular a questão do caráter singular dos empreendimentos, o qual impõem um exame sistemático de cada um deles, eles facilitam o processo de elaboração dos projetos, concentrando e limitando o esforço consagrado a esses aspectos 
singulares. A essa vantagem acrescentam-se outras, como: definir um padrão orientativo de produtos demandados pelo mercado, para a indústria de materiais e componentes e para a rede de distribuição e vendas; estabelecer aspectos essenciais do processo de produção, que possam ser integrados a programas de formação profissional nos seus mais diferentes níveis; ser flexível o suficiente para aceitar as especificidades dos diferentes projetos e, ainda, inovações tecnológicas.

Por outro lado, Bazin (2002) aponta alguns inconvenientes (desvantagens) da utilização dos DTU. Cita o risco de uma excessiva padronização das técnicas, com risco de bloquear as inovações, e com risco de, devido à facilidade que oferece, se negligenciar o estudo e a definição dos aspectos específicos de um dado empreendimento, que acabam sendo improvisados no canteiro. Nesse sentido, é importante que seja dada devida atenção a esta questão pelos profissionais do setor, no intuito de não se fazer um mau uso desses documentos.

\subsection{Reflexões sobre o contexto brasileiro e a adoção dos DTU}

Neste item, primeiramente, é traçado um paralelo entre algumas características similares e outras díspares entre a França e o Brasil, no intuito de se verificar uma possível adaptação dos documentos técnicos franceses ao contexto brasileiro.

Quanto a um aspecto comum no setor da construção civil em ambos os países analisados, tem-se a fragmentação das empresas construtoras e a predominância de empresas de pequeno porte. Segundo o Institut National de la Statistique et des Études Économiques (INSEE), a média de empregados das empresas construtoras francesas do subsetor de edificações é de um pouco menos de 24 trabalhadores (2003), próximo do limite de 19 que caracteriza uma micro empresa industrial brasileira ${ }^{57}$. De acordo com AQC (2006), as construtoras e empresas especializadas que atuam nos canteiros-de-obra com menos de dez funcionários respondem por $93 \%$ do total das empresas (268.000 empresas) e por $48 \%$ do faturamento do setor em 2004. Também, no Brasil, uma característica marcante é a preponderância de inúmeras micro e pequenas empresas construtoras (muitas das quais são também incorporadoras). Portanto, mediante ao porte de tais empresas, não haveria maiores problemas que as mesmas efetuassem a adoção dos DTU.

Outra similaridade é com relação à existência de Programas da Qualidade voltados à construção civil, já citados no início desse capítulo, programas estes que possuem princípios relativamente próximos em ambos os países, não ocasionando obstáculos para a adaptação do DTU e sua introdução no setor.

$57 \mathrm{Na}$ França, o limite que caracteriza uma microempresa é o de 9 trabalhadores. Informações disponíveis em: $<$ http://www.alisse.insee.fr/secteur_btp.html>. Acesso em: 22/3/2006. 
Entretanto, percebe-se que, no Brasil, as empresas do ramo da construção encontram-se dispersas por todo o território nacional e com um forte vínculo a determinada cidade ou região. Sendo assim, a excessiva regionalização das atividades exercidas pelas construtoras, que muitas vezes utilizam materiais e processos construtivos locais, poderia prejudicar a adoção de um documento técnico de caráter unificado, como é o DTU. Isso porque, no Brasil, existem diferenças regionais mais acentuadas, desde natureza climática, geológica, geográfica e de disponibilidade de matérias-primas até de origem cultural. Embora isso crie de fato dificuldades, na França essas mesmas diferenças existem e lá se conseguiu adotar o modelo nacional único, com o cuidado de se excluir dos documentos qualquer caráter de regionalidade. Em função disso, um modelo rigorosamente centralizado de produção de normas e documentos técnicos somente pode ser eficaz se adotar este princípio ou se permitir sensíveis adaptações às realidades de regiões específicas. Assim os documentos técnicos de referência, adaptados com bom senso, permitem que, apesar das diferenças existentes entre os produtos e formas de produção em cada local, se tenha um patamar mínimo de exigência quanto à qualidade e ao desempenho dos edifícios.

Com relação aos aspectos distintos, segundo a ANTAC (2003), é necessário considerar a diferença existente entre os dois países no que tange ao papel do Estado. Retoma-se, aqui, inclusive, o que foi abordado sobre o seguro-construção no item 4.1 desse capítulo. Sem dúvidas, a existência de um seguro desse tipo no Brasil facilitaria a adequada utilização de documentos que constituam o modelo DTU.

Algumas análises conduzidas em comum, entre profissionais da construção civil no Brasil e na França, de acordo com a ANTAC (2003), mostram que a maior diferença entre os setores de produção destes países não reside na competência de seus profissionais, nem mesmo no desenvolvimento tecnológico das indústrias e empresas, mas sim no efeito da "forte capitalização que pôde ser atingida na França, graças a mais de meio século de constância dentro das políticas do habitat conduzidas pelo Estado (orientadas principalmente no habitat social) e à relativa continuidade dos meios econômicos". Essa "capitalização" pode ser relativa à possibilidade de investimentos de capital e esforços contínuos de pesquisa aplicada, bem como a "formação das diversas categorias profissionais, a normalização dos produtos e princípios de execução das obras, a certificação dos produtos e das obras e o desenvolvimento de medidas de seguro-qualidade".

Quanto às empresas construtoras brasileiras, sabe-se que, usualmente, estas possuem seus próprios procedimentos internos relativos aos seus respectivos processos de produção, como procedimentos de execução e controle de serviços, por exemplo. Conforme já citado por Bazin (2002), há de se concordar que cada empreendimento traduz-se por um certo número de escolhas e decisões técnicas que envolvem diversos agentes intervenientes e que, portanto, devem ser especificadas de maneira 
muito precisa para que a obra construída responda ao desejado, ou seja, tenha qualidade, funcionalidade, durabilidade, etc., em conformidade com o proposto inicialmente. Por outro lado, salienta-se que mesmo sendo cada construção única e original, um certo número dessas escolhas, decisões e disposições decorrentes e comumente empregadas, desde que digam respeito a produtos e tecnologias consolidadas e ao projeto considerado, apresentam um caráter repetitivo, independentemente dos agentes específicos de um dado empreendimento. Nesse contexto, ao se considerar que cada empresa é responsável por elaborar seus próprios documentos técnicos, torna-se difícil estabelecer um padrão técnico uniforme de referência a ser exigido dessas empresas. Na prática, geralmente, essas empresas elaboram procedimentos similares ou equivalentes; porém algumas vezes divergentes ou contraditórios, o que tende a gerar 'confusões' entre os agentes do mercado. Tendo em vista essa problemática, Bazin (2002) defende a reprodução no Brasil do modelo francês do Sistema DTU.

Porém, para tanto, é importante ainda que sejam citadas algumas diferenças existentes no Brasil e na França, quanto às atividades de controle do processo de execução de um edifício. Por exemplo, na França tem-se a obrigatoriedade, na prática, da presença do controlador técnico nesse processo, inclusive por exigência do seguro. Por outro lado, no Brasil, somente alguns contratantes contratam empresas gerenciadoras, que cumprem o papel de realizar o controle do processo de execução; entretanto, cada contratante elabora o seu próprio documento, a exemplo do Manual de Controle de Obras e Serviços implementado pela CDHU, o qual será visto no capítulo que se segue. Portanto, também nesse sentido, seria interessante que o Brasil tivesse um documento técnico padrão de referência. Já quanto à especificação do produto edifício, por não ser este o foco do DTU, não cabe nesse caso uma comparação entre o Brasil e a França.

Neste item, são apresentadas algumas reflexões já realizadas por pesquisadores sobre a adoção do DTU francês no contexto brasileiro. Por exemplo, segundo Bazin (2002), o caráter específico do DTU é que ele constitui um Caderno de Encargos padrão proposto aos redatores de contratos de prestação de serviços de execução especializados ou de execução completa de obras, que têm a liberdade de utilizá-lo ou não. Seu real benefício reside, portanto, mais na frequiência ou na generalização do recurso que é feito dele pelos redatores dos contratos do que no seu status de norma em si. Portanto, um procedimento deste tipo no Brasil deveria, segundo o autor, levar em conta este efeito antes de procurar conferir ao documento um status de norma, tanto mais porque no Brasil a noção de norma tem um caráter menos "voluntário" do que o tem, teoricamente, na França.

Dando sequiência às análises de Bazin (2002), o mesmo sugere que uma etapa inicial para poder se elaborar textos segundo uma dinâmica mais rápida e menos restritiva do que a dos mecanismos tradicionais de normalização pode ser constituída partindo-se das necessidades dos contratantes de 
obras ou de agentes influentes como a CAIXA, em conjunto com as entidades setoriais ou sindicatos profissionais do Brasil. Assim, numa segunda etapa, quando tais documentos tiverem demonstrado sua utilidade e sua eficácia, uma reflexão sobre o seu status pode levar a transformá-los em normas técnicas, segundo o autor, "com a condição de que a sua natureza e os princípios que a sustentam não sejam afetados". Esse poderá ser o caso dos documentos de "Requisitos e Critérios Mínimos da CAIXA", vistos no item 3.2.12 do Capítulo 3 desse trabalho.

Para a implantação dos DTU no Brasil, Bazin (2002) propõe um procedimento que associe: a identificação das necessidades e a proposição de mecanismo gerencial e de planejamento do conjunto de ações, bem como uma metodologia de elaboração aplicável a cada documento resultante desse planejamento.

Quanto à identificação das necessidades, a definição das prioridades deve ser feita de acordo com os diferentes critérios, segundo o autor: "caráter repetitivo das técnicas visadas; freqüência dos conflitos entre agentes da construção a respeito dessas técnicas; existência de problemas patológicos prejudiciais à qualidade ou à segurança das obras; e presença de agentes do mercado capazes de sustentarem o processo de maneira voluntária e de se engajarem nas atividades de produção do texto base."

Já quanto à metodologia de elaboração, diz que "a elaboração de um projeto de DTU deve ser confiada a um redator, capaz de reunir o estado-da-arte junto aos profissionais da construção. É conveniente não negligenciar o fato de que na construção civil brasileira, parte das boas práticas e do estado-da-arte, está detida de maneira oral pelos operários e mestre-de-obras. Portanto, redigir um DTU não é levar a boa prática de cima para baixo (da universidade ao canteiro), mas muitas vezes ao contrário, num movimento coordenado de troca, entre os operários do canteiro-de-obra e da infra-estrutura do meio."

Completa ainda o autor que "o resultado dessa redação deverá então ser discutido com os representantes das diferentes profissões envolvidas, para identificar o que é objeto de um razoável consenso. Os pontos de fortes divergências ou sobre os quais se é incapaz de se tomar uma decisão, devem, se possível, conduzir a um remanejamento do escopo tratado para não se ter um atraso na conclusão dos trabalhos". Bazin (2002) sugere, também, a preparação de um modelo que oriente os redatores dos textos base, já que "um modelo para os documentos facilita a sua redação, como também a sua posterior leitura e utilização por outrem desses documentos". Seu documento de 2002 traz, em anexo, uma proposta desse modelo elaborada pela CGNorBât em 2001, válida para a França mas passível de servir de inspiração para o caso brasileiro.

Ainda com relação às reflexões para adaptação do DTU à realidade brasileira, Cardoso (2000) cita que, "como ponto de partida para sua montagem, o setor, qual seja, as empresas, via suas entidades 
setoriais, e os organismos como o Serviço Brasileiro de Apoio às Micro e Pequenas Empresas (SEBRAE) e o Serviço Nacional de Aprendizagem Industrial (SENAI), além de clientes, como a Caixa Econômica Federal e outros, apoiados por agentes de fomento à pesquisa e ao desenvolvimento: FINEP, Conselho Nacional de Desenvolvimento Científico e Tecnológico (CNPq), Fundações de Amparo à Pesquisa dos diferentes estados, entre outros, deveriam investir 'pesado' na consolidação e no avanço dos conhecimentos tecnológicos envolvidos nos diferentes serviços de obras. O CobraCon / CB-02 atuaria, evidentemente, como um agente fundamental nesse processo, assim como os organismos de pesquisas e as universidades. É importante obter recursos significativos, inclusive para viabilizar a transferência de tais conhecimentos às empresas e aos seus funcionários (capacitação)".

Quanto aos desdobramentos do tema para o PBQP-H, Cardoso (2000) destacava, já há cinco anos, a proposta de ação dos agentes do PBQP-H com o CSTB, envolvendo a implantação de Sistema equivalente ao Sistema DTU francês no Brasil (com apoio da CAIXA): “o CSTB passaria sua experiência de organização e gestão do Sistema e sobre os aspectos metodológicos envolvidos, bem como daria auxílio na interpretação dos aspectos tecnológicos existentes em DTU franceses sobre temas afeitos aos 'DTU' brasileiros a serem desenvolvidos, considerados prioritários”.

O autor apresenta, ainda, mais dois outros aprendizados do estágio realizado na França sobre o tema (Barros, 2000; Mitidieri Filho, 2000; Weber, 2000), no âmbito do Projeto de Cooperação apoiado pelo Banco Interamericano de Desenvolvimento (BID). São eles: a importância do envolvimento financeiro das entidades setoriais das construtoras brasileiras no processo de elaboração e gestão do Sistema DTU, que no caso francês suportam a estrutura de produção e gestão dos textos; e a importância de se procurar o consenso na redação dos DTU, sendo que casos complexos e polêmicos não devem ser motivos da constituição de um Comitê de redação.

Também com relação aos desdobramentos do tema para o PBQP-H, Barros (2000) destaca "a necessidade premente de se ter um mecanismo de consolidação do 'saber fazer', no Brasil, para a construção chamada de tradicional", já que "é certo que o Brasil possui, possivelmente pelas suas dimensões continentais, mas não somente por isso, uma grande diversidade de 'saber fazer'”. Segundo a autora, a forma de produção de um processo construtivo no sul do país, possivelmente, é diferente da forma no norte; além disso, os materiais e a tecnologia disponível são diferentes. Portanto, afirma que "dificuldades existem, mas deveremos suplantá-las para que possamos definir um patamar mínimo de qualidade dos produtos, independentemente do seu local de produção".

Ainda de acordo com Barros (2000), a maioria das normas técnicas nacionais disponíveis é afeita a produtos; porém, é preciso ter também as normas de processos, caso contrário, dificilmente conseguese garantir a qualidade do produto final, ou seja, do edifício. Entretanto, a autora cita que: "para que o processo de normalização possa acontecer, é premente que haja uma participação efetiva de diversos 
outros agentes da cadeia produtiva, como por exemplo as construtoras e também os consumidores (empreendedores e usuários), hoje muito distantes do processo de normalização".

Completa a autora que, nesse sentido também, é de grande importância a contribuição de um organismo como o CSTB que poderia auxiliar, "não apenas porque tem consolidado o 'saber fazer francês', mas também pela sua experiência na condução da elaboração dos processos que permitem consolidar a tecnologia construtiva em uso e mais adequada a cada situação". Destaca, ainda, que é importante "que sejam criados mecanismos para estimular o uso da normalização que passará a existir, sendo que este, certamente, constituirá um desafio ainda maior".

O CSTB, segundo a ANTAC (2003), já investiu durante dois anos em alguns dos temas abordados pelo PBQP-H, dentre eles o desenvolvimento de referenciais técnicos unificados para o Brasil. Portanto, algumas trocas de experiência já aconteceram sobre o assunto em questão, que necessitam agora proceder com ações concretas.

Neste capítulo, procurou-se discutir um modelo de referenciais tecnológicos para a construção de edifícios que estivesse sendo utilizado por um país desenvolvido, com reais benefícios para o mesmo. O modelo do DTU já é consolidado na França e, conforme foi visto, já foram realizadas reflexões para sua adaptação ao Brasil, o que foi mais um motivo que levou a selecioná-lo para este estudo. Com a apresentação do DTU, incluindo os procedimentos para sua elaboração, bem como sua estrutura e conteúdo, pretende-se transmitir informações que possam colaborar para o desenvolvimento desses tipos de documentos em âmbito nacional. As reflexões observadas nesse capítulo, feitas por pesquisadores franceses e brasileiros, mostram que, apesar das diferenças citadas e de todos os cuidados a serem tomados, a possibilidade de se adaptar o modelo do Sistema DTU para o contexto brasileiro existe e não está tão distante. Porém, é preciso começar. 


\section{Capítulo 5}

\section{Estudo do manual de CONTROle de obras e SERViços (MCOS) - EXPERIÊNCIA DA CDHU - SÃO PAULO}

Após o estudo de alguns referenciais tecnológicos nacionais, já apresentados no Capítulo 3, o presente capítulo contempla uma análise mais detalhada de um dos documentos utilizados no Brasil, particularmente no Estado de São Paulo.

A escolha pelo estudo do Manual de Controle de Obras e Serviços (MCOS) foi baseada em alguns fatores. Primeiramente, pelo fato desse documento, encomendado pela CDHU ao IPT, ter sido originário de um amplo processo de discussão com as entidades setoriais envolvidas: SindusCon-SP, APEOP e Sindicato Nacional das Empresas de Arquitetura e Engenharia Consultiva (SINAENCO); o que demonstra uma busca pelo consenso técnico entre os profissionais do setor, aspecto que é importante quando se trata de documentos técnicos de referência.

Além disso, o fato de ser um documento que está, atualmente, em vigor no Estado de São Paulo, sendo exigido pelo maior agente promotor de habitações de interesse social do país, é bastante significativo e representativo para a realização de sua análise, visando à qualidade e ao desempenho desses edifícios.

Outro fator que auxiliou na decisão refere-se à realização de um recente projeto entre a CDHU e o IPT com o objetivo de verificar a qualidade dos serviços de execução em obras ${ }^{58}$ promovidos pela Companhia, no Estado de São Paulo, por meio de vistorias técnicas que têm as disposições do MCOS como referência. É importante destacar, aqui, que a pesquisadora do presente estudo é integrante da equipe do IPT que realizou tais vistorias, participando das mesmas no decorrer dos anos de 2003 e 2004; pode, portanto, contribuir com sua experiência prática em relação ao estudo em questão. Além disso, o orientador deste estudo foi coordenador do trabalho de vistorias realizadas pela EPUSP, entre os anos de 2000 e 2001, e participou da equipe que realizou o mesmo trabalho em 2003.

\footnotetext{
${ }^{58}$ Nesse capítulo, o termo 'obra' deve ser entendido como "edifício em construção", conforme definido por Ferreira (2004).
} 
Tem-se, ainda, que o MCOS é definido como sinônimo de "Referenciais Tecnológicos de Serviços, referentes a serviços de execução" na atual versão do Regimento de Qualificação de Sistemas do Programa QUALIHAB (ver item 2.1.1).

Deve-se, no entanto, esclarecer que, nesse trabalho, não se pretende comparar o MCOS diretamente ao DTU (analisado no Capítulo 4), uma vez que o mesmo não foi criado a priori com o intuito de funcionar como o documento francês. Além disso, os DTU contemplam referenciais tecnológicos de procedimentos de execução e controle do processo de execução, incluindo especificações de projetos em anexo, eventualmente. Ao passo que o MCOS aborda somente os referenciais tecnológicos de controle do processo de execução, como se verá adiante. Assim, o estudo do MCOS é realizado em "paralelo" ao do DTU, visando refletir um pouco sobre a realidade nacional (representada pelo Estado de São Paulo).

Este capítulo, de acordo com o item 1.5, trata-se de um estudo descritivo e explanatório, pois tem o propósito de apresentar e descrever o MCOS, bem como explicar seu surgimento, sua utilização e analisar sua aplicação prática. Para tanto, adotam-se as seguintes estratégias de pesquisa para seu desenvolvimento: estudo de caso, levantamento de dados e análise de arquivos, verificando-se, por exemplo, os relatórios técnicos que continham resultados de vistorias realizadas em obras da CDHU que implantaram o MCOS. São respondidas questões como: o que é o MCOS, para que serve, o que contém, quando e onde é utilizado, por quem pode ser empregado, como e por que foi elaborado, quais os resultados obtidos com sua aplicação em obras, por que precisa ser complementado, como está sendo melhorado, etc. Ressalta-se que o MCOS é analisado, neste capítulo, de forma qualitativa, inclusive quanto à análise de sua aplicação prática.

\subsection{Conceituação do MCOS e inserção no Programa QUALIHAB}

O MCOS consiste em uma lista de verificação e desvios admitidos, aplicáveis aos diferentes serviços de execução em obras da CDHU, tratando-se de um documento de referência integrante do Sistema de Qualificação de Empresas de Serviços e Obras do QUALIHAB. Portanto, como parte integrante do Programa, o MCOS deve ser utilizado na realização das auditorias de qualificação dos sistemas de gestão da qualidade das empresas construtoras nos seus diversos níveis.

De acordo com a atual versão do Regimento do QUALIHAB, de 2003, o MCOS é "um conjunto de requisitos definidos pela CDHU que permitem a homogeneidade das ações para o seu controle de produção e de recebimento, contendo, conforme o caso, as tolerâncias permitidas" (conforme item 2.1.1). 
As verificações e os desvios admitidos nos diferentes serviços constantes do Manual devem ser considerados nas obras executadas pelas empresas construtoras e checados pelas empresas gerenciadoras. Nesse sentido, trata-se de um documento contratual imposto pela Companhia às construtoras desde o final de 2002, as quais devem levá-lo em conta em seus sistemas de gestão da qualidade. Assim, o MCOS é exigido de forma contratual pela CDHU (contratante) às empresas construtoras e gerenciadoras que a ela prestam serviços (contratadas), baseando-se na relação de comprometimento entre as partes. Essa característica também é importante para balizar um documento técnico de referência.

Deste modo, as empresas devem adequar os seus procedimentos de execução e de inspeção de serviços de tal forma que os mesmos levem a produtos que atendam não somente às especificações e exigências dos tradicionais Projetos e Memoriais Descritivos, mas, também, ao que preconiza o MCOS.

É importante relembrar aqui que, na contextualização do tema em estudo, a inserção do MCOS no Sistema de Qualificação do Programa QUALIHAB é realizada de acordo com o já exposto na Figura 4 (Capítulo 2), visando ao objetivo final da qualidade assegurada para os conjuntos habitacionais da CDHU. Assim, para o MCOS, como referencial tecnológico, tem-se quanto ao tripé de sustentação do Programa, que: o Manual foi desenvolvido atendendo à "base" relativa a implementação de normalização ou documentação técnica de referência; sendo exigido nas obras da CDHU, no âmbito da "base" do sistema de gestão da qualidade das empresas construtoras; e, considerando-se que futuramente poderá ser utilizado para auxiliar a "base" de treinamento e qualificação da mão-de-obra, juntamente com documentos técnicos complementares.

\subsection{Histórico do surgimento do MCOS}

Conforme exposto por Cardoso; Vivancos; Jesus (2001), sob a ótica do ciclo PDCA ${ }^{59}$ (JURAN; GRYNA, 1988), algumas ações foram, e estão sendo, realizadas para a retroalimentação do Programa QUALIHAB, analisando a sua efetividade de implantação e os resultados obtidos na qualidade dos edifícios entregues pela CDHU, visando identificar os pontos críticos e as necessidades de melhorias. Dentre estas ações destacam-se, para o presente estudo, as que culminaram na elaboração do MCOS.

Segundo Jesus (2004), no ano 2000, quatro anos após a instituição oficial do Programa, a CDHU entendeu ser o momento apropriado para a verificação da efetividade dos programas setoriais por ela promovidos. De acordo com a autora, a Companhia, preocupada com a qualidade da habitação que

${ }^{59}$ Ciclo PDCA: Plan-Do-Check-Act, isto é, planejar, fazer, verificar e agir rumo à melhoria contínua. 
estava sendo entregue à população de baixa renda, estabeleceu que tal verificação deveria concentrarse nos Programas Setoriais da Qualidade mais diretamente ligados à execução do produto habitação os dos setores de execução de obras e de gerenciamento de empreendimentos. Além disso, estes eram dois setores cujos programas setoriais já estavam em pleno funcionamento há quase um ano, na ocasião. A CDHU promoveu tais verificações por meio da realização de vistorias técnicas às suas obras.

As vistorias foram realizadas sem o prévio aviso das empresas envolvidas - construtoras e gerenciadoras - e somente em canteiros de obra, não sendo verificadas as atividades dos sistemas de gestão da qualidade desenvolvidas nas sedes das empresas. Desta forma, pôde-se observar como, de fato, se desenvolviam as atividades rotineiras de gestão da qualidade em canteiros de obras de empresas qualificadas no Programa QUALIHAB.

Inicialmente, foram vistoriados dez canteiros de obras por equipes de duas instituições que receberam a missão de conduzir tais vistorias, a EPUSP e o IPT, com os seguintes objetivos: observar a efetividade da implementação dos sistemas de gestão da qualidade nas empresas construtoras e gerenciadoras; verificar a qualidade dos serviços acabados ou em execução; e verificar as condições gerais dos canteiros de obras e da implantação dos conjuntos habitacionais (JESUS, 2004).

As análises dos resultados das vistorias, segundo a autora, foram capazes de provocar movimentação no setor na busca de melhorias e soluções, uma vez que a responsabilidade pelos problemas apontados deveria ser compartilhada por todos os agentes envolvidos. A CDHU atuou, na época, junto com as entidades signatárias dos acordos setoriais - SindusCon-SP, APEOP, Sinaenco e Sindicato Intermunicipal de Araçatuba das Indústrias de Construção Civil (SindusCon-OESP) - com o intuito de realizar as revisões cabíveis nos acordos setoriais, para seu realinhamento com as necessidades das partes interessadas. Verificou-se que, na maioria das obras vistoriadas, os sistemas de gestão da qualidade encontravam-se implementados de maneira parcial e as habitações ainda não haviam se beneficiado de melhorias efetivas quanto à sua qualidade.

Foi também constatado, na mesma pesquisa, que as ações relativas ao treinamento da mão-de-obra e desenvolvimento de normalização técnica, duas das pernas do tripé de sustentação do Programa, estavam menos implementadas do que aquelas relativas ao sistema de gestão da qualidade. Assim, em relação ao treinamento, principalmente dos profissionais que atuam diretamente na produção, tanto os empregados das construtoras quanto de empresas subcontratadas, ficou clara a necessidade das entidades setoriais desencadearem ações nesse sentido, o que vem sendo desde então exigido pela CDHU, tomando como base o acordo setorial. 
Já quanto ao desenvolvimento de normalização técnica, segundo a autora, ficou evidenciada sua importância e a necessidade da Companhia promover o desenvolvimento de documentos que permitissem melhor explicitar requisitos técnicos para a melhoria da qualidade e adequado desempenho que ela espera de seus conjuntos habitacionais. Portanto, ressaltou-se a importância do desenvolvimento de referenciais tecnológicos para a construção habitacional, que pudessem ser utilizados como parâmetros ou referenciais mínimos de especificação do produto, procedimentos de execução e controle do processo de produção dos empreendimentos. E é essa idéia que o presente trabalho pretende aprimorar, tendo-se visto o inicial desenvolvimento de alguns documentos técnicos de referência por parte da CDHU.

Por exemplo, foram elaborados documentos estabelecendo especificações a serem observadas ao longo das obras e pelos produtos entregues (CDHU, s.dt.a; s.dt.b; s.dt.c), que vieram a se somar às peças gráficas dos Projetos e aos Memoriais Descritivos dos diferentes empreendimentos da Companhia (JESUS, 2004). Além disso, como documentação técnica de referência para projetos da CDHU, relacionada à proposta de sistema da qualidade de projetos desenvolvida segundo IPT (1996) apud Hino (2001), foram desenvolvidos os seguintes documentos:

- Manual Técnico de Serviços: define parâmetros e diretrizes para os serviços de investigação de superfície, reconhecimento do subsolo, parecer geotécnico e topografia;

- Manual de Procedimentos para Contratação de Serviços Preliminares e Projetos: constitui regras administrativas e definição de critérios para avaliação e classificação do prestador de serviço, aspectos de cadastramento, critérios para avaliação de projetos, procedimentos para recebimento de projetos e serviços, bem como indicações para escolha de empresas que participam de licitações por carta-convite;

- Manual Técnico de Projetos: fornece orientações para a elaboração de projetos, estabelecendo procedimentos, diretrizes técnicas, produtos a serem obtidos e normas de apresentação; inclui, ainda, os Programas de Projeto de Urbanismo e Edificação, definindo-se as necessidades funcionais e sociais a serem alcançadas, bem como os parâmetros para desenvolvimento dos projetos das diversas especialidades;

- Memorial Descritivo e Especificações Técnicas: define características, de acordo com as diversas tipologias empregadas, para os componentes e elementos de processos construtivos em alvenaria estrutural ou com estrutura de concreto armado e vedações verticais de alvenaria; os serviços tratados nesses documentos são os seguintes: fundação, estrutura, alvenaria, laje, cobertura, forro, revestimento interno e externo, piso interno e externo, esquadrias, ferragens, vidros, pintura, impermeabilizações e instalações elétricas, hidráulico-sanitárias, de gás, telefônicas e de combate a incêndio. 
Dentre os documentos citados, o de maior interesse para o presente estudo é o Memorial Descritivo e Especificações Técnicas.

Entretanto, apesar da existência de tais documentos, as vistorias técnicas realizadas no ano de 2000 concluíram que ainda existia a necessidade de se desenvolver outros documentos técnicos de referência como, por exemplo, que formalizassem requisitos e parâmetros de controle da qualidade de obras e serviços de execução a serem exigidos pela CDHU, de forma padronizada. E foi assim, mediante o contexto exposto, que se iniciou o processo para a elaboração do MCOS, culminando com a sua efetiva publicação em dezembro de 2002.

\subsection{Objetivos do MCOS}

O Manual de Controle de Obras e Serviços visa homogeneizar as ações de inspeção e recebimento de serviços realizadas pelas construtoras e gerenciadoras, bem como fornecer elementos para se realizar o controle da qualidade na execução das obras promovidas pela CDHU.

Percebe-se, portanto, que o MCOS não é um referencial tecnológico de especificação do produto, nem mesmo de procedimentos de execução dos serviços. Tal Manual é, sim, um documento técnico de referência somente para o controle do processo de produção das construções habitacionais, focalizado na etapa dos serviços de execução. Assim, a CDHU consegue exigir, de forma padronizada, o que ela pretende controlar nos serviços durante a execução das obras, no intuito de que tais controles reflitam na melhoria da qualidade e do desempenho do produto final.

Além disso, o MCOS acaba também disseminando informações e conhecimento a respeito das exigências de controle do processo de produção das obras, mesmo não sendo este o seu objetivo principal.

\subsection{Estrutura e Conteúdo do MCOS}

O MCOS contém uma lista de serviços e itens de verificação para edificações verticais e horizontais. Para cada serviço são dados os parâmetros de aceitação, de acordo com suas respectivas referências técnicas, que podem ser as normas técnicas nacionais ou o Memorial Descritivo e Especificações Técnicas da CDHU. Caso o parâmetro não conste em norma nem nos documentos da CDHU, ou caso dependa de características particulares de cada edifício, a referência é dada pelo próprio projeto executivo. 
Ainda quanto aos parâmetros de aceitação, além de serem apresentados os valores requeridos conforme as normas técnicas oficiais e suas respectivas tolerâncias, são também indicadas as tolerâncias admitidas pela CDHU.

O Manual apresenta ainda um tópico de observações que, quando necessário, descreve os equipamentos utilizados para a medição e realização do controle dos serviços, além de outras observações quando pertinentes.

A seguir, o Quadro 1 mostra como a disposição desses tópicos é apresentada no Manual.

Quadro 1 - Esquema ilustrativo da estrutura do MCOS.

\begin{tabular}{|c|c|c|c|c|c|}
\hline \multirow{3}{*}{$\begin{array}{l}\text { Serviços - Itens } \\
\text { de Verificação }\end{array}$} & \multirow{3}{*}{ Referência } & \multicolumn{3}{|c|}{ Parâmetros de Aceitação } & \multirow{3}{*}{ Observações } \\
\hline & & \multicolumn{2}{|c|}{ Norma } & \multirow{2}{*}{$\begin{array}{c}\text { Tolerância } \\
\text { CDHU }\end{array}$} & \\
\hline & & Requerido & Tolerância & & \\
\hline \multicolumn{6}{|l|}{1 - Itens } \\
\hline \multicolumn{6}{|l|}{1.1 - Subitens } \\
\hline & & & & & \\
\hline & & & & & \\
\hline & & & & & \\
\hline & & & & & \\
\hline
\end{tabular}

São abordados os seguintes serviços (ou itens de verificação): serviços preliminares (instalação do canteiro e locação); fundação; estrutura (alvenaria estrutural e lajes); alvenaria de vedação; cobertura; revestimento (interno e externo); pisos (interno e externo); esquadrias (incluindo vidros); pintura (interna e externa); complementos (peitoril, soleira e suporte do tanque); aparelhos sanitários e metais; instalações hidráulicas (água fria e esgoto); instalação de gás; instalações elétricas; reservatório de água superior; hidrômetro; centro de medição; sistema de drenagem, talude natural e muro de contenção; e preparação e compactação de aterros. Cada item de verificação possui seus respectivos subitens ${ }^{60}$.

É importante ressaltar que o MCOS foi elaborado para ser utilizado como referencial tecnológico de controle da execução dos serviços, devendo ser complementado por documentos que contenham as especificações do projeto e os procedimentos de execução e inspeção dos serviços em cada uma das

\footnotetext{
${ }^{60}$ Por exemplo, para o ‘item’ fundação, os 'subitens' são: radier, estaca moldada in loco, sapata corrida, blocos e baldrames, estaca pré-moldada, tubulão e sapata isolada (MCOS, 2002).
} 
obras realizadas; sendo que os demais documentos devem ser elaborados de forma que atendam às exigências contidas no MCOS.

\subsection{Retroalimentação do MCOS (IPT/CDHU)}

Após a publicação do MCOS, suas disposições passaram a ser exigidas pela CDHU no processo de produção dos conjuntos habitacionais por ela promovidos. Assim, considerada a implementação efetiva do Manual, a CDHU solicitou ao IPT que fizesse um trabalho, cujo objetivo foi verificar a qualidade dos serviços em execução nas obras e a conformidade destes com projetos, especificações e, principalmente, com todas as referências e exigências de controle do MCOS.

O desenvolvimento do trabalho IPT/CDHU consistiu em um amplo Projeto, que teve como base a realização de vistorias técnicas em determinadas obras, as quais eram indicadas pela Companhia. $\mathrm{O}$ propósito era realizar as vistorias técnicas no decorrer das etapas do processo de produção dos conjuntos habitacionais, verificando-se a execução dos serviços ${ }^{61}$, desde os serviços preliminares, fundação, estrutura, instalações até o revestimento, acabamento final e serviços complementares. Em cada etapa, as vistorias técnicas eram feitas considerando-se os requisitos, parâmetros e tolerâncias constantes do MCOS. Como resultado, buscava-se, além de identificar e evitar a repetição de nãoconformidades nas obras, colaborar para um processo de retroalimentação do conteúdo do MCOS.

Este Projeto iniciou-se a partir do final de 2002 e estendeu-se até meados de 2004, sendo que as vistorias técnicas foram realizadas em obras que se localizavam na região metropolitana do Estado de São Paulo.

Assim, foram indicadas 65 obras, que se encontravam em andamento no período de análise. Cada obra deveria ser vistoriada, pelo menos duas vezes, no intuito de se analisar pelo menos duas etapas distintas de execução da mesma obra, bem como de se verificar se as não-conformidades observadas na etapa anterior, ou seja, na primeira vistoria, tinham sido corrigidas. Entretanto, por motivos de limitação no cronograma de prazo para o trabalho, das 65 obras em questão, somente 35 puderam ser vistoriadas duas vezes, sendo que as outras 30 obras tiveram apenas uma única vistoria técnica. Portanto, obteve-se um total de 100 vistorias realizadas no período.

\footnotetext{
${ }^{61}$ Foram verificados, além de serviços, os materiais controlados pelo QUALIHAB, definidos no documento normativo do Programa que estabelece as exigências que o sistema de gestão da qualidade das empresas construtoras deve atender; entretanto, a avaliação dos materiais não faz parte do escopo do presente estudo.
} 
Para a análise de cada uma das obras, foi estipulada, previamente, uma amostragem considerada representativa para o estudo. Definiu-se que a vistoria deveria ser feita em $1 \%$ dos apartamentos do total previsto no projeto do conjunto habitacional ${ }^{62}$, com o limite mínimo de 3 apartamentos. Além disso, os serviços de execução referentes às áreas comuns, escadarias, telhados e fachadas deveriam ser vistoriados em, pelo menos, 2 edifícios do respectivo conjunto habitacional.

Em tais amostras, para a coleta dos dados nas vistorias, foram utilizadas listas de verificação (checklists), especialmente desenvolvidas para o trabalho em questão visando homogeneizar e direcionar o estudo. Tais listas foram elaboradas com base nas exigências do MCOS. Além disso, para a realização das segundas vistorias, foi preparada uma planilha adicional visando a identificação dos itens que haviam sido corrigidos, durante o intervalo de tempo decorrido entre a primeira e a segunda vistoria ao conjunto habitacional em questão.

Para as vistorias técnicas ainda se contava com a experiência dos técnicos integrantes da equipe do IPT. Assim, quando necessário, também foram constatadas não-conformidades que estavam ocorrendo nas obras e que não constavam do Manual. $\mathrm{O}$ registro de tais não-conformidades, verificadas nos projetos ou nos serviços de execução, era feito caso as mesmas pudessem prejudicar a qualidade das obras ou o desempenho dos edifícios. Nesse caso, a indicação de aspectos que não eram citados no MCOS foi entendida como inerente ao ciclo PDCA, no sentido de agregar melhorias ao Manual.

Após a finalização de cada vistoria, o IPT emitia um relatório técnico à CDHU, informando as nãoconformidades verificadas na obra, sendo estas constantes ou não do MCOS. No relatório ainda eram recomendadas ações corretivas e preventivas para as não-conformidades citadas.

\subsection{Análise do conteúdo do MCOS à luz da aplicação prática}

A análise do conteúdo do MCOS, realizada neste item, foi motivada pelo desenvolvimento do trabalho IPT/CDHU apresentado no item anterior (5.5). Assim, a análise aqui elaborada considera os resultados qualitativos da aplicação prática do MCOS nas obras vistoriadas durante o citado Projeto.

Dessa maneira, o objetivo do presente estudo é verificar se as exigências contidas no MCOS, para a realização do controle de serviços de execução são, em geral, suficientes ou não para garantir a qualidade dos mesmos e da obra em questão. Pretende-se, assim, não somente alimentar as discussões desta dissertação sobre os referenciais tecnológicos de controle do processo de execução, como

\footnotetext{
${ }^{62}$ Entende-se, aqui, que cada conjunto habitacional é constituído por uma certa quantidade de edifícios.
} 
também colaborar com o aprimoramento de tal Manual, contribuindo para sua complementação ou para uma reavaliação de seu modelo.

Entretanto, como essa análise é baseada em um Projeto que possui escopo bastante abrangente, verificou-se a necessidade de se estipular e definir alguns critérios, segundo uma metodologia, para delimitar tal análise e focar no objetivo do presente estudo.

Primeiramente, por não ser viável, nesta dissertação, a análise do conteúdo de todos os serviços contemplados pelo MCOS, decidiu-se realizá-la apenas para um dos serviços. No caso, o critério para seleção foi o seguinte: dever-se-ia optar pelo serviço que tivesse tido não-conformidades no maior número de obras vistoriadas, isto é, o serviço analisado seria aquele que possuísse maior percentual de obras com não-conformidades em sua execução. Para facilitar o entendimento, foi elaborado um gráfico com o percentual de obras que tinham pelo menos uma não-conformidade nos respectivos serviços em execução, o qual pode ser visto na Figura 10.

Porcentagem de obras com não-conformidades nos respectivos serviços de execução (Projeto IPT/CDHU)

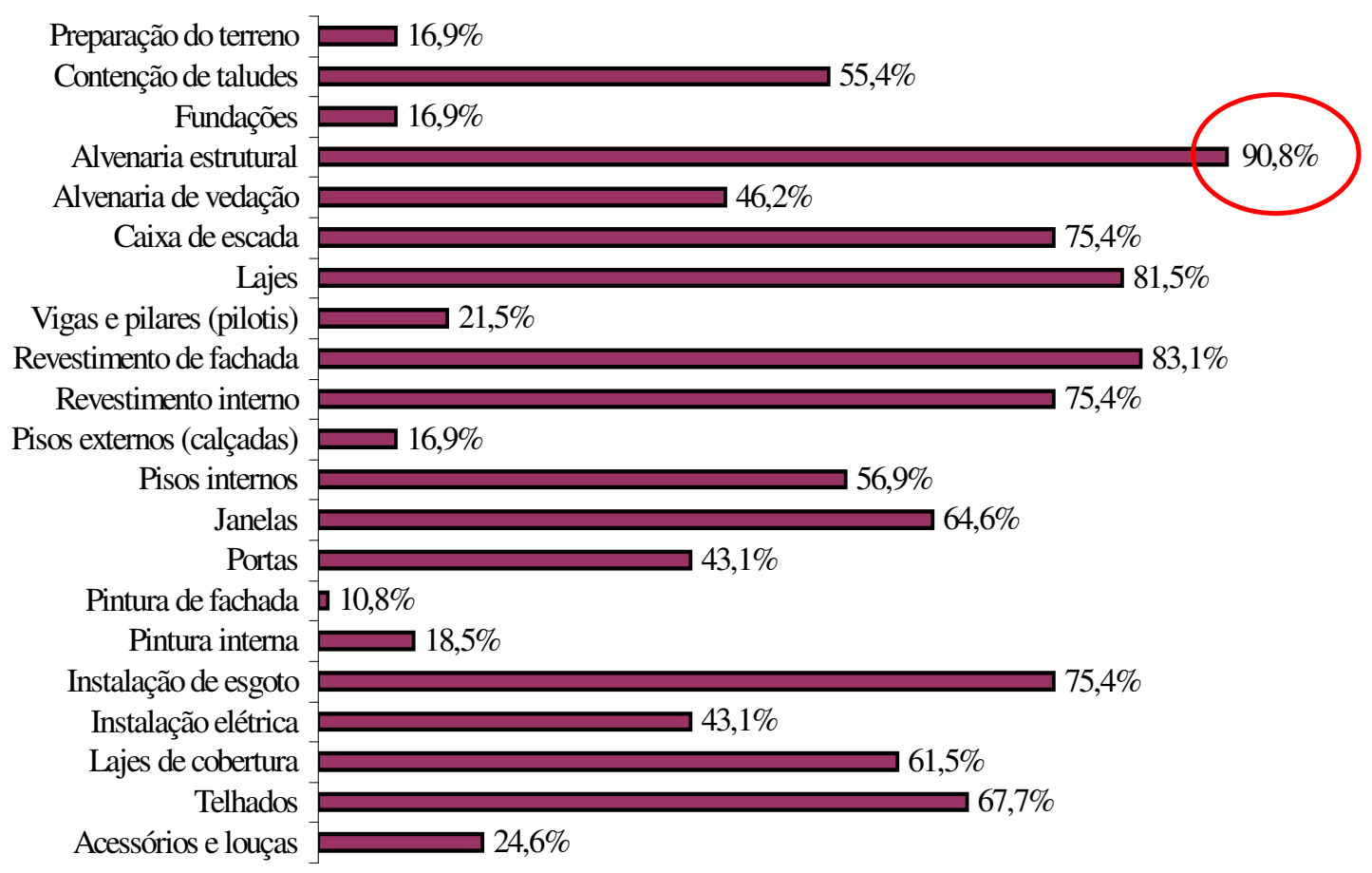

Figura 10 - Percentual de obras com não-conformidade nos serviços de execução, no Projeto IPT/CDHU. (Fonte: Baseado em IPT, 2004) 
Portanto, da observação do gráfico da Figura 10, tem-se que o serviço a ser estudado deve ser a execução da alvenaria estrutural, por apresentar pelo menos uma não-conformidade em 90,8\% das obras vistoriadas no Projeto IPT/CDHU ${ }^{63}$, durante o período de análise.

Além disso, também não seria conveniente estudar, aqui, pela quantidade, todas as obras que se encontravam na etapa de execução da alvenaria estrutural, seja na primeira vistoria ou na segunda. Para delimitar o escopo da análise, no presente estudo, decidiu-se utilizar o seguinte critério: dentre as obras que foram vistoriadas duas vezes pela equipe do IPT seriam selecionadas apenas as obras que estavam na fase de execução da alvenaria estrutural tanto na primeira quanto na segunda vistoria realizada. Desse modo, é possível observar diferentes aspectos em momentos distintos da execução desse serviço, além de verificar se algumas não-conformidades constatadas na primeira vistoria foram corrigidas ou não na segunda, conforme as exigências do MCOS. Assim, de acordo com esse critério, foram identificadas 5 obras, entendendo-se que cada obra corresponde à execução de um conjunto habitacional promovido pela CDHU. Tais obras foram nomeadas no presente trabalho: Obra A, Obra B, Obra C, Obra D e Obra E.

A título de conhecimento e caracterização das obras a serem estudadas, primeiramente, são apresentadas as descrições do projeto de implantação de cada uma delas (ver Tabela 9), sabendo-se que a tipologia dos apartamentos é: dois dormitórios, sala, cozinha, banheiro e área de serviço.

Tabela 9 - Descrição do projeto de implantação das obras estudadas (conjuntos habitacionais).

(Fonte: Baseado em IPT, 2004)

\begin{tabular}{l|c|c|c|c|c}
\hline \multicolumn{1}{c|}{$\begin{array}{c}\text { Descrição do projeto de } \\
\text { implantação }\end{array}$} & Obra A & Obra B & Obra C & Obra D & Obra E \\
\hline Quantidade de edifícios & 16 & 8 & 30 & 44 & 56 \\
\hline Quantidade de pavimentos & 5 & $11 / 10^{*}$ & 5 & 5 & $4 * *$ \\
\hline N $^{\circ}$ de apartamentos / pavimento & 4 & 5 & 4 & 4 & 4 \\
\hline Quantidade de apartamentos & 320 & 420 & 300 & 440 & 444 \\
\hline
\end{tabular}

(*) Quatro edificios com onze pavimentos e quatro com dez pavimentos mais pilotis.

(**) No andar térreo tem-se o Centro de Apoio Comunitário.

Apresentam-se, também, as principais características construtivas de cada uma das obras quanto aos serviços de fundação, estrutura, revestimento, dentre outros, que podem ser visualizados na Tabela 10.

\footnotetext{
${ }^{63}$ Foi realizado, segundo IPT (2004), um levantamento das não-conformidades encontradas nas obras vistoriadas. Foram considerados quaisquer problemas ocorridos, constantes ou não do MCOS. Salienta-se que caso a não-conformidade tivesse sido corrigida na segunda vistoria, a mesma não foi considerada para a análise. Ressalta-se que $100 \%$ das obras vistoriadas foram executadas em alvenaria estrutural, sendo 86,2\% utilizando blocos de concreto e 13,8\% blocos cerâmicos.
} 
É importante notar a repetitividade de tais características nas obras analisadas, uma vez que isto colabora para a aplicação de um documento técnico de referência padrão.

Tabela 10 - Principais características construtivas das obras estudadas (conjuntos habitacionais). (Fonte: Baseado em IPT, 2004)

\begin{tabular}{|c|c|c|c|c|c|c|}
\hline \multirow{2}{*}{\multicolumn{2}{|c|}{ Principais características construtivas }} & \multicolumn{5}{|c|}{ Obras } \\
\hline & & $\mathbf{A}$ & $\mathbf{B}$ & $\mathrm{C}$ & $\mathbf{D}$ & F \\
\hline \multirow{6}{*}{ Fundação } & Estacas escavadas & & \multirow{6}{*}{ 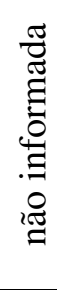 } & & & $\bullet$ \\
\hline & Estacas pré-fabricadas em concreto & $\bullet$ & & $\bullet$ & $\bullet$ & \\
\hline & Vigas baldrames pré-fabricadas em concreto & $\bullet$ & & & & \\
\hline & Vigas baldrames em concreto moldadas no local & & & $\bullet$ & $\bullet$ & $\bullet$ \\
\hline & Blocos de ligação moldados no local & $\bullet$ & & & & $\bullet$ \\
\hline & Sapata corrida & & & & & $\bullet$ \\
\hline Estrutura & Alvenaria estrutural com blocos de concreto & $\bullet$ & $\bullet$ & $\bullet$ & $\bullet$ & $\bullet$ \\
\hline \multirow{2}{*}{ Vedação } & Alvenaria de vedação com blocos de concreto & $\bullet$ & $\bullet$ & & $\bullet$ & $\bullet$ \\
\hline & Alvenaria de vedação com blocos cerâmicos & & & $\bullet$ & & \\
\hline \multirow{2}{*}{ Lajes } & Concreto armado moldadas no local & & $\bullet$ & $\bullet$ & & $\bullet$ \\
\hline & Concreto, pré-moldadas no canteiro de obra & $\bullet$ & & $\bullet$ & $\bullet$ & \\
\hline \multirow{2}{*}{ Escadas } & Concreto armado moldadas no local & & $\bullet$ & & & $\bullet$ \\
\hline & Concreto pré-moldada no canteiro de obra & $\bullet$ & & $\bullet$ & $\bullet$ & \\
\hline \multirow{4}{*}{ Revestimentos } & Interno (aptos): Argamassa & $\bullet$ & $\bullet$ & $\bullet$ & $\bullet$ & $\bullet$ \\
\hline & Interno (aptos): Gesso (áreas secas) & $\bullet$ & $\bullet$ & $\bullet$ & $\bullet$ & \\
\hline & Interno (aptos): Placas cerâmicas (banheiro) & $\bullet$ & $\bullet$ & $\bullet$ & $\bullet$ & \\
\hline & Externo (fachadas): Argamassa & $\bullet$ & $\bullet$ & $\bullet$ & $\bullet$ & $\bullet$ \\
\hline \multirow{2}{*}{ Pintura } & Interna (apartamentos): PVA & $\bullet$ & $\bullet$ & $\bullet$ & $\bullet$ & $\bullet$ \\
\hline & Externa (fachadas): Acrílica & $\bullet$ & $\bullet$ & $\bullet$ & $\bullet$ & $\bullet$ \\
\hline \multirow{4}{*}{ Pisos } & Banheiros: Cerâmica & $\bullet$ & $\bullet$ & $\bullet$ & $\bullet$ & $\bullet$ \\
\hline & Cozinhas e Áreas de Serviço (AS): Cerâmica & & & $\bullet$ & $\bullet$ & $\bullet$ \\
\hline & Cozinhas e AS: Concreto desempenado & $\bullet$ & $\bullet$ & & & \\
\hline & Áreas secas: Concreto desempenado & $\bullet$ & $\bullet$ & $\bullet$ & $\bullet$ & $\bullet$ \\
\hline \multirow{3}{*}{ Instalações } & Elétrica: embutida nas paredes e lajes & $\bullet$ & $\bullet$ & $\bullet$ & $\bullet$ & $\bullet$ \\
\hline & $\begin{array}{l}\text { Esgoto: tubo PVC soldável, embutida nas paredes } \\
\text { e expostas sob as lajes }\end{array}$ & $\bullet$ & $\bullet$ & $\bullet$ & $\bullet$ & $\bullet$ \\
\hline & $\begin{array}{l}\text { Água fria: em tubo PVC soldável, embutidas nas } \\
\text { paredes }\end{array}$ & $\bullet$ & $\bullet$ & $\bullet$ & $\bullet$ & $\bullet$ \\
\hline \multirow{3}{*}{ Esquadrias } & Janelas: Aço & $\bullet$ & $\bullet$ & $\bullet$ & $\bullet$ & $\bullet$ \\
\hline & Portas: Aço (entrada da sala) & $\bullet$ & $\bullet$ & $\bullet$ & $\bullet$ & $\bullet$ \\
\hline & Portas: Madeira (dormitórios e banheiro) & $\bullet$ & $\bullet$ & $\bullet$ & $\bullet$ & $\bullet$ \\
\hline \multirow{4}{*}{ Cobertura } & Estrutura do telhado: Metálica & & & & $\bullet$ & $\bullet$ \\
\hline & Estrutura do telhado: Madeira & $\bullet$ & $\bullet$ & $\bullet$ & & \\
\hline & Telhas: Cerâmicas tipo 'Romana' & $\bullet$ & & $\bullet$ & $\bullet$ & $\bullet$ \\
\hline & Telhas: Metálicas tipo 'Trapezoidais’ & & $\bullet$ & & & \\
\hline
\end{tabular}

Após a descrição e caracterização das obras estudadas, procede-se à análise do conteúdo do MCOS, por meio de sua aplicação prática a estas, durante as vistorias técnicas. Os dados analisados foram obtidos nos relatórios técnicos elaborados para as respectivas obras. 
A análise é feita comparando-se as não-conformidades encontradas nas obras com os respectivos requisitos e tolerâncias constantes ou não do Manual. Assim, o objetivo é verificar até que ponto o conteúdo do MCOS, enquanto exigências para evitar ou minimizar não-conformidades na execução do serviço de alvenaria, neste caso, está sendo suficiente ou não, face às constatações observadas nas obras. Porém, deve-se levar em conta que, por exigência da CDHU, as empresas construtoras atuantes em suas obras possuem sistemas de gestão da qualidade, que exigem a implementação de procedimentos de execução e de inspeção para os serviços considerados críticos, como é o caso da alvenaria estrutural.

Os requisitos e tolerâncias contemplados pelo Manual, para o serviço de alvenaria estrutural, podem ser vistos no ANEXO A (Quadro 2), do presente trabalho. Com base em tais exigências, e na experiência da equipe que realizou as vistorias, foram apontadas algumas constatações a respeito da execução do serviço de alvenaria estrutural nas obras estudadas. Para facilitar a visualização, elaborouse um resumo das principais constatações, incluindo as não-conformidades observadas durante a execução de tal serviço, tanto na ocasião da primeira vistoria quanto da segunda, em cada uma das obras. Este resumo encontra-se no APÊNDICE A (Quadro 3 ao Quadro 12).

Assim, as análises são realizadas após as constatações apresentadas em cada obra em estudo, e tendose como base o conteúdo do MCOS para o serviço de alvenaria estrutural.

Primeiramente, foi elaborada uma planilha apenas com as não-conformidades encontradas que tinham seus respectivos requisitos ou suas tolerâncias contemplados pelo MCOS. Ou seja, são nãoconformidades que poderiam ter sido evitadas, caso fosse aplicado, efetivamente, o conteúdo do Manual. Desse modo, o não atendimento das obras ao conteúdo do MCOS, nas duas vistorias realizadas em cada, pode ser visto na Tabela 11 , na página seguinte.

Neste caso, em que o serviço está sendo executado em desconformidade com as exigências já contempladas pelo MCOS, poder-se-ia pensar na possibilidade de se elaborar recomendações ou procedimentos de execução, com suficiente detalhamento, ou mesmo realizar um programa de treinamento para a mão-de-obra que efetivamente executa cada serviço. Tais medidas devem ser complementadas com os auto-controles realizados pelas empresas construtoras e com o acompanhamento dos serviços por parte das empresas gerenciadoras, para que seja evitada a ocorrência dessas não-conformidades em questão. 
Tabela 11 - Não-atendimento aos requisitos constantes do MCOS para o serviço de alvenaria estrutural, nas obras estudadas. (Fonte: Baseado em IPT, 2004)

\begin{tabular}{|c|c|c|c|c|c|c|c|c|c|c|}
\hline \multirow{3}{*}{$\begin{array}{c}\text { Não-conformidades encontradas nas obras } \\
\text { e que possuem os respectivos requisitos ou } \\
\text { tolerâncias expressos no MCOS }\end{array}$} & \multicolumn{10}{|c|}{ Obras / Vistorias } \\
\hline & \multicolumn{2}{|c|}{$\mathbf{A}$} & \multicolumn{2}{|c|}{ B } & \multicolumn{2}{|c|}{$\mathbf{C}$} & \multicolumn{2}{|c|}{ D } & \multicolumn{2}{|c|}{$\mathbf{E}$} \\
\hline & $\mathbf{1}^{\mathrm{a}}$ & $2^{a}$ & $\mathbf{1}^{\mathrm{a}}$ & $2^{\mathbf{a}}$ & $\mathbf{1}^{\mathrm{a}}$ & $2^{\mathrm{a}}$ & $\mathbf{1}^{\mathrm{a}}$ & $2^{\mathrm{a}}$ & $1^{a}$ & $2^{\mathrm{a}}$ \\
\hline Falha no alinhamento vertical (prumo) & & & & $\mathrm{x}$ & & & & & & \\
\hline $\begin{array}{l}\text { Espessura inadequada ou falha no } \\
\text { preenchimento das juntas horizontais }\end{array}$ & $\mathrm{X}$ & & $\mathrm{X}$ & $\mathrm{X}$ & $\mathrm{X}$ & & $\mathrm{X}$ & $\mathrm{X}$ & & \\
\hline $\begin{array}{l}\text { Espessura inadequada ou falha no } \\
\text { preenchimento das juntas verticais entre blocos }\end{array}$ & $\mathrm{X}$ & & $\mathrm{x}^{*}$ & $x^{*}$ & $x^{*}$ & $\mathrm{x}^{*}$ & $\mathrm{X}$ & $\mathrm{X}$ & $\mathrm{X}$ & $\mathrm{X}$ \\
\hline $\begin{array}{l}\text { Desvios de planaridade: irregularidade abrupta, } \\
\text { acima da tolerância especificada }\end{array}$ & & & & $\mathrm{X}$ & & & & & & \\
\hline $\begin{array}{l}\text { Abertura de vãos (horiz./vert.), acima da } \\
\text { tolerância especificada }\end{array}$ & & & & & & $\mathrm{X}$ & & & & \\
\hline Falha na colocação da armação horizontal & & & & & $\mathrm{X}$ & & & $\mathrm{x}$ & & \\
\hline $\begin{array}{l}\text { Procedimento inadequado para lançamento / } \\
\text { preenchimento total do graute }\end{array}$ & & & & & $\mathrm{X}$ & & & & & \\
\hline
\end{tabular}

(*) juntas secas - não preenchidas.

Entretanto, verificando-se os Quadros do APÊNDICE A, relativos às constatações de nãoconformidades para o serviço de alvenaria estrutural nas obras estudadas, observa-se que, por outro lado, muitas das não-conformidades encontradas não possuíam, no MCOS, seus respectivos requisitos ou tolerâncias segundo os quais poderiam ter sido evitadas. Assim, para auxiliar a análise sobre a necessidade de se incorporar ou não outras exigências ao Manual, foi elaborada uma planilha (Tabela 12, vista na página a seguir) somente com as não-conformidades encontradas que não têm seus respectivos requisitos ou tolerâncias citados no conteúdo do MCOS, mas que podem influenciar direta ou indiretamente a qualidade ou o desempenho dos edifícios.

É importante deixar claro, aqui, que o MCOS foi elaborado visando contemplar somente requisitos e tolerâncias relacionados ao controle da execução, propriamente dita, e do recebimento dos serviços. Mesmo assim, a análise desse estudo indica que ainda seria necessário complementá-lo quanto a algumas exigências de controle do processo de produção dos edifícios.

Considerando-se que haja o cumprimento efetivo do MCOS nas obras promovidas pela CDHU percebe-se, por meio da análise do conteúdo do Manual, que a introdução de determinados itens de verificação no documento poderiam evitar ou minimizar a ocorrência de algumas não-conformidades na execução dos serviços, contribuindo para a melhoria da qualidade das obras e do desempenho dos edifícios. 
Tabela 12 - Ocorrência, nas obras estudadas, de não-conformidades cujos requisitos ou tolerâncias não fazem parte do conteúdo do MCOS. (Fonte: Baseado em IPT, 2004)

\begin{tabular}{|c|c|c|c|c|c|c|c|c|c|c|}
\hline \multirow{3}{*}{$\begin{array}{c}\text { Não-conformidades verificadas que não } \\
\text { possuem respectivos requisitos ou tolerâncias } \\
\text { especificados no MCOS }\end{array}$} & \multicolumn{10}{|c|}{ Obras / Vistorias } \\
\hline & \multicolumn{2}{|c|}{ A } & \multicolumn{2}{|c|}{ B } & \multicolumn{2}{|c|}{$\mathbf{C}$} & \multicolumn{2}{|c|}{ D } & \multicolumn{2}{|c|}{$\mathbf{E}$} \\
\hline & $\mathbf{1}^{\mathrm{a}}$ & $2^{\mathrm{a}}$ & $1^{\mathrm{a}}$ & $2^{\mathbf{a}}$ & $\mathbf{1}^{\mathrm{a}}$ & $2^{\mathbf{a}}$ & $\mathbf{1}^{\mathrm{a}}$ & $2^{\mathrm{a}}$ & $\mathbf{1}^{\mathrm{a}}$ & $2^{\mathrm{a}}$ \\
\hline $\begin{array}{l}\text { Corte inadequado dos blocos-canaleta para } \\
\text { colocação de peitoril }\end{array}$ & & & & & & $\mathrm{x}$ & & & & \\
\hline $\begin{array}{l}\text { Execução inadequada das contra-vergas e } \\
\text { vergas de janelas e/ou portas }\end{array}$ & & & & & & $\mathrm{x}$ & & $\mathrm{x}$ & & $\mathrm{X}$ \\
\hline Escoramento inadequado das vergas & & & & & & & $\mathrm{x}$ & & & \\
\hline $\begin{array}{l}\text { Ausência de janelas de inspeção para controle } \\
\text { do grauteamento }\end{array}$ & & & & $\mathrm{x}$ & & & & & & \\
\hline Fissura nos blocos & & & $\mathrm{x}$ & $\mathrm{x}$ & $\mathrm{x}$ & $\mathrm{x}$ & $\mathrm{x}$ & & $\mathrm{x}$ & $\mathrm{x}$ \\
\hline $\begin{array}{l}\text { Quebras excessivas nas paredes para passagem } \\
\text { de eletrodutos ou tubulações }\end{array}$ & & & & $x$ & $x$ & $\mathrm{x}$ & $\mathrm{x}$ & $\mathrm{x}$ & & $\mathrm{X}$ \\
\hline $\begin{array}{l}\text { Falta de homogeneidade dos blocos (dimensão, } \\
\text { textura, tonalidade) }\end{array}$ & & & $\mathrm{x}$ & & $\mathrm{x}$ & $\mathrm{x}$ & $\mathrm{X}$ & $\mathrm{x}$ & $\mathrm{x}$ & \\
\hline Armazenamento inadequado dos blocos & & $\mathrm{x}$ & $\mathrm{x}$ & & & & $\mathrm{x}$ & $\mathrm{x}$ & $\mathrm{x}$ & \\
\hline $\begin{array}{l}\text { Cura inadequada dos blocos fabricados no } \\
\text { canteiro de obras }\end{array}$ & & & $x$ & & & $\mathrm{x}$ & $\mathrm{x}$ & $\mathrm{x}$ & $\mathrm{x}$ & \\
\hline $\begin{array}{l}\text { Ausência de ensaio ou não-conformidade no } \\
\text { ensaio de graute (consistência ou resistência) }\end{array}$ & $\mathrm{x}$ & & & & $\mathrm{x}$ & $\mathrm{x}$ & & & $\mathrm{x}$ & $\mathrm{X}$ \\
\hline $\begin{array}{l}\text { Resistência da argamassa de assentamento } \\
\text { (acima ou abaixo da especificada) }\end{array}$ & & & & & & $\mathrm{x}$ & $\mathrm{x}$ & & & \\
\hline $\begin{array}{l}\text { Ausência de ensaio ou não-conformidade no } \\
\text { ensaio de blocos (umidade e absorção) }\end{array}$ & $\mathrm{x}$ & & & & & & $\mathrm{x}$ & & & \\
\hline $\begin{array}{l}\text { Ausência de ensaio ou não-conformidade no } \\
\text { ensaio de argamassa de assentamento } \\
\text { (resistência ou consistência) }\end{array}$ & $\mathrm{x}$ & & & & & & & & & \\
\hline Eflorescências nos blocos & & & & & & & & $\mathrm{x}$ & & \\
\hline $\begin{array}{l}\text { Resistência do graute não-conforme com a } \\
\text { especificada }\end{array}$ & & & & & & & & $\mathrm{x}$ & & \\
\hline $\begin{array}{l}\text { Juntas a prumo entre as paredes, com ausência } \\
\text { ou insuficiência de amarração }\end{array}$ & & & & & & & $\mathrm{x}$ & $\mathrm{x}$ & $\mathrm{x}$ & \\
\hline $\begin{array}{l}\text { Fissuras nos vértices das janelas (vergas e } \\
\text { contra-vergas) }\end{array}$ & & & & $\mathrm{x}$ & & & & & & \\
\hline $\begin{array}{l}\text { Ausência de preenchimento das juntas verticais } \\
\text { (juntas secas) }\end{array}$ & & & $\mathrm{x}$ & $\mathrm{x}$ & $\mathrm{x}$ & $\mathrm{x}$ & & & & \\
\hline $\begin{array}{l}\text { Destacamento no encontro entre guarda-corpo } \\
\text { e paredes de alvenaria estrutural }\end{array}$ & & & & $\mathrm{x}$ & & & & & & \\
\hline
\end{tabular}


Observa-se que, além de outras não-conformidades relacionadas ao controle de execução do serviço, ainda são apontadas algumas que se relacionam com deficiências nos procedimentos de projeto, de planejamento e gestão do processo de execução da obra, bem como não-conformidades encontradas nos materiais, as quais podem prejudicar a qualidade ou o desempenho do edifício e de suas partes. Isso porque o nível de desempenho e satisfação proporcionado pela construção aos usuários vai depender da qualidade obtida em todas as etapas do processo de produção do empreendimento, assim como dos serviços de operação e manutenção.

Em relação aos serviços de execução, têm-se na Tabela 12, por exemplo, as quebras excessivas nas paredes para passagem de eletrodutos ou tubulações. Seria interessante ter recomendações para esse procedimento de execução citando, dentre outros cuidados, as ferramentas a serem utilizadas para o serviço. Tais quebras, caso não sejam adequadamente tratadas, podem, futuramente, causar fissuras na alvenaria estrutural, o que prejudica a qualidade da parede em questão e, dependendo da gravidade do caso, pode interferir também no seu desempenho. Poderia também se fazer uma recomendação de projeto (referencial tecnológico de especificação de produto), propondo o embutimento das instalações, o que traria reflexos para os procedimentos de execução.

Ainda da Tabela 12, observa-se que a não-conformidade correspondente às "juntas a prumo entre as paredes, com ausência ou insuficiência de amarração" é decorrente da etapa de projeto do edifício. Assim, essa deficiência na amarração entre as paredes, que não foi prevista em projeto, pode, no futuro, gerar uma fissura vertical no canto da parede de alvenaria, também influenciando na qualidade e no desempenho desse componente.

Tem também, por exemplo, a não-conformidade relativa à cura inadequada dos blocos de concreto utilizados para execução da alvenaria estrutural. Esse procedimento gera um material com resistência mecânica prejudicada, tendo-se um risco de desenvolvimento de fissuras nas paredes, além de um eventual prejuízo à aderência de argamassas de revestimento. Portanto, para os blocos fabricados nos canteiros de obra, seria interessante especificar o procedimento adequado para a cura dos mesmos, evitando que um material de qualidade ruim influencie a qualidade e o desempenho da alvenaria estrutural.

Quanto aos materiais, tem-se que as não-conformidades obtidas nos ensaios de grautes, argamassas de assentamento ou blocos podem comprometer a qualidade e o desempenho do sistema construtivo. Por exemplo, problemas com a consistência do graute podem causar um mau adensamento do mesmo, comprometendo o desempenho estrutural da parede; e problemas com a alta absorção dos blocos podem causar fissuras por retração após secagem, afetando a qualidade final da alvenaria. 
Alguns cuidados relativos ao planejamento e gestão do processo de produção também evitariam nãoconformidades como o armazenamento inadequado dos blocos (o assentamento de blocos úmidos pode causar eflorescências, por exemplo) ou a ocorrência de fissuras nos blocos devida, por exemplo, ao transporte e manuseio inadequado dos mesmos (os blocos já com fissuras, se utilizados, comprometem a qualidade e o desempenho das paredes de alvenaria).

O que se pretende mostrar, aqui, é que alguns aspectos relativos ao planejamento, projeto, execução, controle do processo de execução dos serviços e até mesmo controle dos materiais, que afetam direta ou indiretamente a qualidade e o desempenho do produto final, poderiam ser contemplados por documentos técnicos de referência do tipo do MCOS.

De qualquer forma, constatou-se, nessas vistorias, a importância da CDHU ter implantado um documento técnico de referência como o MCOS nas suas obras, o qual quanto ao tipo, trata-se de um referencial tecnológico de controle do processo. Isso porque, apesar da quantidade significativa de não-conformidades encontradas nas obras estudadas, verifica-se que com a continuidade do uso do MCOS, considerando-se o seu aprimoramento e sua aplicação efetiva nas obras, deve ser possível melhorar a qualidade do produto final, uma vez que esta é influenciada, também, pela qualidade dos serviços na etapa de execução do processo de produção dos edifícios.

\subsection{Opinião de um construtor sobre o MCOS}

Ainda no intuito de se verificar a aplicação prática do MCOS, foi realizada uma entrevista ${ }^{64}$ com um diretor de obras de uma empresa construtora que presta serviços para a CDHU e estava utilizando o Manual em suas obras. A empresa é de médio porte (possui 50 funcionários diretos e, aproximadamente, 400 indiretos), faz incorporação e construção de habitações de interesse social no Estado de São Paulo (tendo na época da entrevista 10 obras em andamento) e atua no mercado já há 25 anos.

Primeiramente, quanto ao processo de elaboração e desenvolvimento do MCOS, o entrevistado disse que o Manual foi criado para unificar e padronizar o entendimento da produção de edifícios da CDHU, evitando-se as dúvidas entre a construtora, a gerenciadora e o cliente. Isso porque antes cada construtora desenvolvia seus próprios parâmetros de controle, existindo "alguns qualitativos e poucos quantitativos que, geralmente, eram conflitantes entre as empresas".

\footnotetext{
${ }^{64}$ Entrevista realizada no dia 2 de agosto de 2005, na sede da empresa do entrevistado.
} 
Segundo ele, a discussão entre os agentes envolvidos na elaboração do documento, da qual fez parte das reuniões, tinham o objetivo de "conceituar os problemas observados nas obras, trabalhar as soluções e homogeneizar os entendimentos". O entrevistado afirmou ser este um processo evolutivo, no qual as condições cumpridas num dado momento são melhoradas com o tempo. Isso porque se tem ciência de que talvez hoje ainda não se tenham as condições ideais, mas sim as condições que são aceitas para se obter um patamar mínimo de qualidade. Cita que, por exemplo, "se uma exigência é muito rigorosa para os padrões desse tipo de construção, tal valor exigido é revisto, de modo a ser aplicável na prática do dia-a-dia, mesmo que não esteja em conformidade com as normas técnicas vigentes" (trata-se aqui de uma posição polêmica, que é simplesmente reproduzida, sem se discutir o mérito).

O diretor de obras entrevistado ainda expôs que o objetivo da CDHU era atender às seguintes premissas: "segurança das habitações, bom aspecto visual e diminuição de manutenção". Para tanto a elaboração do documento foi feita item a item, analisando cada serviço, com a experiência prática das construtoras e o conhecimento acumulado do IPT. Tais análises geraram discussões a respeito do controle tecnológico exercido no processo de produção dos edifícios (o que controlar exatamente e em qual amostragem), já que se trata de um documento não oficial. Houve também discussões sobre os projetos utilizados para as habitações (muitas vezes eram utilizados projetos antigos nas licitações), desencadeando uma série de reuniões e providências internas da CDHU.

Segundo o entrevistado, os procedimentos de execução são "livres" para cada empresa, uma vez que não cabe à CDHU interferir nesse processo. Entretanto, ressalta que o Memorial Descritivo da Companhia poderia ser melhorado. Além disso, cita que a primeira base para a elaboração dos Procedimentos de Execução dos Serviços (PES) e Procedimentos de Inspeção dos Serviços (PIS) foi apresentada em um curso no SindusCon-SP, por uma empresa privada, porém tais procedimentos, principalmente os de execução, traziam especificações muito detalhadas, complexas e prescritivas, o que levou a maioria das construtoras a realizar adaptações nos mesmos.

O Manual, publicado no final de 2002, não foi exigido para os contratos que já estavam em andamento, ficando estes em um "período de observação", enquanto para os novos contratos ele já passou a ser de uso obrigatório.

$\mathrm{Na}$ opinião do entrevistado, foram observadas mudanças positivas em relação à qualidade dos serviços de execução, devido à introdução de parâmetros quantitativos uniformes de controle e em relação às exigências tanto das construtoras quanto das gerenciadoras, uma vez que para estas tornou-se mais fácil de se cobrar. Quanto à produtividade dos serviços, até aquele momento, acredita que não foram verificados prejuízos na velocidade e qualidade de execução. Entretanto, o entrevistado afirma que o mercado ainda tem de se adequar, já que em alguns casos a exigência mais rigorosa acabou 
introduzindo custos adicionais e dificuldades antes não constatadas. Assim, ele enxerga os benefícios ainda a médio e longo prazo, quando os funcionários já estiverem devidamente treinados e, portanto, conseguindo cumprir todos os requisitos e tolerâncias do MCOS, visto que este é um documento contratual.

Quanto à aceitação e à adaptação ao Manual por parte dos funcionários, o diretor de obras acha que quem "mais sofreu" foram os mestres-de-obras, pois estes tinham o seu próprio conhecimento, muitas vezes adquirido por sua experiência de trabalhos anteriores, e eles mesmos disseminavam esse conhecimento entre os outros funcionários. Logo, com o surgimento do Manual, eles acharam que perderam um pouco do seu "poder", sendo que os demais funcionários estariam menos dependentes dele e passariam, então, a seguir as exigências já impostas pelo MCOS. Quanto aos sub-empreiteiros, também foram verificadas dificuldades devido ao pouco tempo que, em geral, ficam efetivamente nas obras, pois o sistema não está sendo tão ágil para permitir treinamentos nesses casos. Em relação aos engenheiros das construtoras e gerenciadoras, pelo o que ele pôde perceber, o Manual está sendo bem aceito nas obras, porém com algumas reclamações quanto a certos parâmetros ou tolerância que não estavam, ainda, conseguindo-se atingir.

Quanto ao processo para a apresentação do MCOS aos funcionários, o entrevistado deixou claro que dependia da "conveniência da obra". Geralmente, em suas obras, o treinamento era feito com um funcionário encarregado para a execução de cada um dos serviços, sendo este o responsável pela transmissão das instruções ao seu respectivo grupo, como por exemplo o de alvenaria estrutural.

Ao ser questionado quanto ao conteúdo do Manual e às modificações necessárias, o diretor de obras disse que os serviços contemplados são suficientes, porém cita que "alguns problemas na redação ainda podem gerar dúvidas de interpretação" e sugere, ainda, que algumas exigências sejam complementadas. Sugeriu que, apesar de os projetos já terem documentos específicos da CDHU, algumas exigências poderiam estar contidas nesse Manual, como por exemplo, citar que "é necessário ter um projeto de modulação dos blocos para a execução da alvenaria, que atenda a tais e tais exigências de desempenho da parede". Quanto aos materiais e componentes, a CDHU também possui fichas específicas para o controle dos mesmos, porém especificações gerais, segundo o entrevistado, poderiam ser colocadas junto aos serviços no MCOS. Com relação ao planejamento da obra, sugere não descrevê-lo, mas sim explicitar o que se espera que seja gerado com um planejamento adequado. Quanto ao uso e manutenção, apesar de se ter um Manual do Proprietário e do Síndico, os problemas ocorridos na manutenção do edifício deveriam retroalimentar as exigências das inspeções feitas no decorrer do controle do processo de produção do mesmo, de forma sistemática e rápida. Ou seja, vistas as não-conformidades no produto depois de acabado, por exemplo por meio de vistorias técnicas pósocupação, as exigências que evitariam tais problemas deveriam ser inseridas no Manual. Assim, 
sugere "verificar quais serviços geram problemas sistematicamente na manutenção dos edifícios, gerando um banco de dados que retroalimente o conteúdo do documento".

Quanto às verificações em obra, o entrevistado sugere que sejam apresentados critérios de amostragem. Cita que "seria bom que fosse explicitada uma amostragem para o recebimento dos serviços, seguindo uma norma com certo grau de confiabilidade. Isso porque segundo o PIS, tal inspeção deve ser global, isto é, em 100\% dos elementos, o que faz com que muitas empresas apenas registrem a verificação mas não a façam efetivamente".

Para otimizar o uso do MCOS, quanto ao controle dos serviços, o entrevistado sugere que seja explicitada uma amostragem diferente para cada tipo de serviço, por exemplo, classificar os serviços de acordo com as prioridades (segurança estrutural, etc). Sugere, também, verificar o nível de recorrência dos problemas, instituindo diferente importância a eles e definindo quem fiscaliza cada serviço e quantas vezes.

Outra sugestão dada pelo entrevistado é que, ao se executar pela primeira vez um serviço, que este seja feito com um maior rigor quanto ao cumprimento dos parâmetros adotados no MCOS, para que "gere um entendimento dos funcionários quanto à qualidade do trabalho exigido". A partir de então, caso o funcionário não execute adequadamente os serviços, poderia ser aplicada uma penalidade "de custo", isto é, seria retida uma porcentagem de seu salário, para que da próxima vez os mesmos erros não venham a se repetir.

Como uma crítica geral, o diretor de obras diz que o Manual cita apenas especificações exigidas dos produtos da construção, não sendo apresentado, em geral, o "como controlar" a execução propriamente dita. Além disso, existem alguns aspectos exigidos do produto que devem ser controlados na etapa de projeto e não da execução, os quais deveriam estar citados também no documento.

Por fim, o entrevistado sugere a criação de "fichas" que centralizem as informações para cada serviço, juntando informações "de todos os documentos", de modo a facilitar o entendimento e o uso, além de diminuir as chances de se ter informações divergentes em documentos diferentes.

Assim, as idéias propostas pelo entrevistado, como as sugestões para a melhoria do conteúdo de um manual desse tipo, bem como as críticas feitas à sua aplicação prática, podem ser incorporadas na elaboração e uso de novos documentos técnicos de referência, não somente no âmbito da CDHU, mas sim contribuindo para o desenvolvimento de referenciais tecnológicos que possam ser utilizados na construção de edifícios em geral, sendo que o seu adequado uso contribuiria para melhorias práticas no dia-a-dia nas obras, principalmente quanto à qualidade dos serviços e desempenho do produto final. 


\subsection{Processo de aprimoramento do MCOS}

Após o estudo iniciado neste trabalho, a equipe do IPT envolvida no Projeto das vistorias técnicas nas obras da CDHU realizou, em 2005, uma revisão de todos os serviços e itens de verificação contidos no MCOS, considerando a análise das não-conformidades encontradas em todas as vistorias realizadas.

Assim, como parte do Projeto IPT/CDHU, foram emitidos relatórios técnicos de compilação das nãoconformidades de execução dos serviços, ocorridas nas 100 vistorias efetuadas, incluindo as causas de tais não-conformidades e propostas de condutas e procedimentos para minimizar a ocorrência das mesmas. A revisão do MCOS foi feita com base no resultado de tal compilação, comparando-se as não-conformidades levantadas, com os itens de verificação e seus respectivos requisitos e tolerâncias constantes do Manual, hora em vigor. Essa revisão, proposta pelo IPT, ainda será discutida com representantes da CDHU, APEOP, SindusCon-SP e SINAENCO; porém, já se caracterizou como sendo mais um "passo" no processo de aprimoramento do MCOS.

Cabe, aqui, observar que a revisão proposta para o MCOS também incorpora somente requisitos e tolerâncias relativos ao controle da execução ou recebimento de serviços e obras, não contemplando controles relativos a materiais, projetos, gestão nem manutenção das edificações. Salienta-se que, quanto às exigências para os materiais, foram propostas fichas para controle de recebimento e uso dos mesmos, elaboradas pelo IPT em 2002. Quanto aos projetos, já existem algumas referências da CDHU, sendo que também foi feito um trabalho, em 2003, com o IPT, técnicos da CDHU e representantes do SindusCon-SP, APEOP e SINAENCO, para detectar falhas construtivas resultantes de inadequações de projeto e solucioná-las. E quanto aos procedimentos, cada empresa construtora possui seus próprios documentos técnicos de referência internos, como os usualmente denominados Procedimentos de Execução dos Serviços (PES) e Procedimentos de Inspeção de Serviços (PIS), já citados no item anterior, utilizados conforme condição exigida para a qualificação do sistema de gestão da qualidade dessas empresas.

Porém, o que se observa é que a exigência de aspectos que não constam de um documento técnico de referência padrão, isto é, que não possuem um consenso entre os agentes envolvidos, torna-se mais difícil, uma vez que tais aspectos não são realizados nem cobrados de forma homogênea. Portanto, analisando o exposto nesse estudo, questiona-se se não seria interessante complementar o próprio Manual ou desenvolver outros documentos técnicos de referência, segundo o mesmo processo de elaboração do MCOS, que contemplassem, por exemplo, especificações de projeto que fossem relevantes para garantir o adequado desempenho dos edifícios, características exigidas para os materiais a serem utilizados e recomendações de cuidados a serem tomados nos procedimentos de execução. Ressalta-se que os aspectos relativos aos procedimentos de execução devem ter como 
finalidade o atrelamento ao conceito de desempenho dos conjuntos habitacionais, ou seja, não é necessário fixar uma forma de execução rígida e padronizada para as construtoras, desde que estas atendam às condições de desempenho exigidas. Portanto, também seria importante um documento que definisse os critérios e requisitos de desempenho que se deseja obter nos edifícios.

Por fim, considerando o atual MCOS como referencial tecnológico de controle do processo de produção do edifício, verificou-se o quão importante é que sejam identificadas as principais atividades que devem ser controladas durante a execução de um determinado serviço, bem como as que devem ser verificadas para o recebimento desse serviço (ou elemento de construção) depois de acabado, evitando-se problemas patológicos futuros caso os serviços não tenham sido executados corretamente. Entretanto, analisando-se além da revisão e do aprimoramento do MCOS, observou-se que é interessante pensar no desenvolvimento de um documento técnico de referência que tenha um conceito e escopo mais abrangente, ou seja, que contemple, por exemplo, o conteúdo do caderno de cláusulas técnicas dos documentos franceses (DTU). Este documento seria um referencial tecnológico a ser aplicado e exigido pela CDHU em todas as suas obras, contribuindo para garantir a qualidade do processo de produção de seus conjuntos habitacionais.

Conclui-se, desse capítulo, que a apresentação do conceito de um referencial tecnológico de controle do processo de execução de edifícios, em vigor (nesse caso relativo às habitações de interesse social), bem como a observância de algumas das dificuldades encontradas na aplicação desse documento e ainda de certas deficiências apontadas em seu conteúdo, contribuem como experiência prática para a elaboração e aplicação de novos documentos técnicos de referência de maneira geral, aproveitando os pontos positivos do desenvolvimento do exemplo aqui visto e descartando ou minimizando os negativos. 


\section{Capítulo 6}

\section{AnÁlises e discuSsões SOBRe REFERENCIAIS TECNOLÓGICOS PARA A CONSTRUÇÃO DE EDIFÍCIOS}

Neste capítulo são apresentadas, resumidamente, algumas considerações sobre os principais assuntos tratados nesse estudo. Além disso, o objetivo é realizar análises a respeito dos documentos estudados no trabalho, discutindo aspectos relevantes e propondo orientações que possam contribuir para a elaboração e implantação de atuais referenciais tecnológicos na construção de edifícios no Brasil.

\subsection{Quanto ao contexto e às interfaces}

Partindo-se da definição previamente exposta no início do trabalho, ao se abordar o que são os referenciais tecnológicos e apresentar algumas aplicações dos mesmos, verificou-se que o contexto atual do setor da construção de edifícios reflete que, além da necessidade de se implementar uma documentação técnica de referência no país, o momento para a sua efetivação encontra-se mais propício.

Um dos motivos é o desenvolvimento de Programas da Qualidade relativos aos edifícios e à habitação, de âmbito nacional, o PBQP-H e também regional como o QUALIHAB no Estado de São Paulo, o QUALIOP na Bahia, e outros em Estados como Minas Gerais, Rio de Janeiro, etc., os quais visam a melhoria da qualidade das habitações, principalmente das de interesse social, por serem em geral as que mais necessitam de investimentos nessa área. Com isso, os referenciais tecnológicos podem, e devem, estar inseridos em tais Programas, sendo voltados à qualidade não só do processo de produção dessas edificações como também tendo o foco na qualidade do produto final. Entretanto, quanto a essa inserção, percebe-se que a efetividade de sua implementação, quanto à elaboração, ao uso e à exigência dos mesmos, ainda é uma ação incipiente. Por exemplo, no Regimento do SiAC, do PBQP$\mathrm{H}$, referente à execução de obras, tem-se que os referenciais tecnológicos, "quando vierem a existir" e forem reconhecidos pela Comissão Nacional, serão considerados nas auditorias para a certificação da conformidade do sistema de gestão da qualidade das empresas construtoras. Dessa forma, por um lado, é deixada clara a relação entre os referenciais tecnológicos e os sistemas de gestão das empresas; estas criaram uma cultura que permite não só a aceitação como o reconhecimento do interesse dos 
referenciais. No entanto, por outro lado, pode-se perceber que alguns referenciais tecnológicos ainda não existem (devido ao citado "quando vierem a existir") e, desse modo, precisam ser elaborados, ressaltando-se a importância de se desenvolver, com maior ênfase, a base relativa ao desenvolvimento de normalização técnica e documentos técnicos de referência do tripé de sustentação desses Programas da Qualidade, conforme visto na Figura 4, do Capítulo 2. O mesmo pode ser observado para o QUALIHAB, em São Paulo.

Paralelamente, o desenvolvimento da normalização técnica nacional de desempenho de edifícios habitacionais de até cinco pavimentos (que acontece mais de 20 anos após o tema começar a ser discutido no país), definindo critérios e requisitos de desempenho, contribui e facilita a inserção de padrões já homogêneos na elaboração de referenciais tecnológicos, principalmente os que dizem respeito à especificação do produto. Tais padrões de desempenho já são largamente utilizados em documentos técnicos de referência estrangeiros, como, por exemplo, o Uniform Building Code (UBC) nos EUA e o NHBC-Standards no Reino Unido, apresentados respectivamente nos itens 3.1.1 e 3.1.5 desse trabalho. Entretanto, acredita-se que, no Brasil, a cultura de especificação de desempenho dos produtos ainda precisa ser mais consolidada.

Tem-se ainda, um outro motivo indutor ao desenvolvimento dos referenciais tecnológicos, que é representado pela atual "era do conhecimento", devido à tecnologia da informação e a todos os processos de informatização que estão ocorrendo cada vez mais rápido no Brasil e no mundo. Percebese, portanto, maior facilidade em formalizar e, principalmente, disseminar o conhecimento, ações estas que são resultantes quando da elaboração e do uso de possíveis referenciais tecnológicos. Desse modo, observa-se que os referenciais tecnológicos podem colaborar não somente para a melhoria da qualidade e do desempenho dos edifícios, mas também para o processo de formalização e difusão do conhecimento, tendo, portanto, uma relação com knowledge management (gestão do conhecimento). Conseqüentemente, os referenciais tecnológicos podem ser considerados uma inovação tecnológica, com termos de informação e organização. Nesse contexto, uma outra análise a ser feita, aqui, é que os documentos mais atuais já se encontram informatizados, devido à tecnologia da informação. Assim, por exemplo o Caderno de Encargos da SUCAB e o Guia da Qualidade dos Processos Construtivos são documentos de acesso via softwares, o que permite periódicas atualizações de seus conteúdos técnicos. Além disso, alguns documentos podem ser encontrados em sites na Internet, como as Práticas da SEAP, os documentos técnicos da CAIXA, as Recomendações Técnicas HABITARE e o próprio MCOS, o que permite a facilidade de acesso a um número significativamente maior do que os documentos técnicos tradicionais, ou mais antigos, que, em geral, encontram-se exclusivamente em bibliotecas. 
Mostra-se ainda um outro aspecto positivo do ambiente, o de que importantes agentes da cadeia produtiva têm voltado seu interesse para os referenciais, como a CDHU, a CAIXA e o SENAI, para não citar um exemplo de cada tipo de agente. Observa-se, também, uma modernização de mecanismos já existentes, como os da União (SEAP) e da SUCAB.

Por outro lado, como contexto para elaboração de tais documentos deve-se considerar, também, que no Brasil os agentes envolvidos na cadeia produtiva do setor da construção civil apresentam diversos portes empresariais e diferentes níveis de tecnologia agregada em seus processos. Além disso, outra característica marcante é a preponderância de pequenas e médias construtoras (muitas das quais são também incorporadoras), dispersas pelo território e com um forte vínculo a determinada cidade ou região. Esses aspectos precisam ser pensados quando da elaboração de um referencial tecnológico no país.

Mesmo assim, conclui-se que o cenário nacional para a implementação dos referenciais tecnológicos encontra-se favorável, mais aberto a inovações, inclusive tecnológicas, tendo sofrido algumas mudanças e evoluções e estando, talvez, mais preparado do que estava antes, quando da elaboração de alguns dos documentos aqui estudados.

Portanto, para se iniciar o processo de elaboração de tais documentos seria interessante definir quais são os referenciais tecnológicos prioritários, de acordo com o contexto do setor da construção de edifícios em geral e habitacional em especial. Considera-se, primeiramente, que existe uma peculiaridade do processo produtivo do edifício que é a sua articulação em torno de empreendimentos únicos, não repetitivos e vinculados a determinado local de produção. Porém, como visto, apesar da não repetitividade estrita do produto, muitos dos procedimentos de produção permanecem os mesmos na execução de várias obras de uma mesma empresa ou de uma mesma tipologia de construção. Assim, sugere-se que sejam prioritariamente elaborados os documentos técnicos de referência que possam ser utilizados em construções que apresentem essa certa repetitividade do processo de produção, o que ocorre, por exemplo, no caso das habitações de interesse social, promovidas pelo Estado, que, geralmente, têm especificações similares de projetos, procedimentos de execução e controles.

\subsection{Quanto ao conceito de referenciais tecnológicos}

Face ao contexto propício já exposto, primeiramente, para a exigência efetiva por parte dos principais Programas da Qualidade do setor da construção civil no Brasil, é necessário que o conceito de referenciais tecnológicos seja padronizado, isto é, que seja um termo entendido da mesma forma por todos. Isso, porque, conforme visto no item 2.1 desse trabalho, atualmente, as definições de 
referenciais tecnológicos pelo QUALIHAB e PBQP-H, por exemplo, não se encontram homogêneas, pelo contrário, parecem até mesmo contraditórias; haja vista a abordagem do primeiro Programa com o foco de tais documentos em requisitos de "controle de produção e recebimento", enquanto o segundo Programa afirma serem documentos com recomendações práticas para "projeto, produção, instalação, manutenção ou utilização do produto".

Assim, de acordo com o que foi estudado nesse trabalho, especialmente quanto aos diferentes tipos de referenciais tecnológicos apresentados no Capítulo 3, pode-se sugerir que o conceito definido pelo QUALIHAB, em 2003, seja mais abrangente, tornando-se mais próximo do definido pelo PBQP-H, em 2005. Isso porque ao colocar o termo "referenciais tecnológicos referentes a serviços de execução" como sinônimo do MCOS, percebe-se que o QUALIHAB está contemplando, apenas, o tipo de documento referente ao controle do processo de construção (incluindo o controle de recebimento dos serviços), e não contendo práticas para projeto nem produção, como consta da definição do PBQP-H, nem das etapas pós-entrega do edifício.

Porém, caso o QUALIHAB não pretenda expandir o escopo do termo "referenciais tecnológicos", desejando manter a atual definição ainda como sinônimo do MCOS, sugerem-se duas alternativas: ou se deixa claro que está sendo abordado apenas o tipo de documento de controle do processo (e recebimento de serviços) ou se amplia o escopo do MCOS, incorporando as demais práticas ou procedimentos vistos no atual Regimento do PBQP-H (SiAC).

Também quanto ao conceito de referenciais tecnológicos, tem-se ainda a questão do citado documento "não normativo", conforme definição do PBQP-H. Entende-se que foi correta a escolha de uma referência clara a esse fato, por duas razões. Primeiramente, pois isso permitiu, quando da revisão do Regimento do SiAC, não se criar um ponto polêmico, cuja discussão pouco teria agregado ao processo, tendo sido mantido o essencial, qual seja, a referência explícita aos referenciais tecnológicos no texto, associando-os a uma definição abrangente, conforme visto anteriormente. Em segundo lugar, como decorrência do entendimento que os instrumentos legais brasileiros dão às normas técnicas, como o Código de Defesa do Consumidor, caracterizá-los como normas significaria criar um ambiente bastante conservador quando da elaboração de um documento, pois haveria o receio permanente deste trazer complicações futuras para as empresas; mais uma vez o que se quer é um ambiente favorável ao desenvolvimento e à implantação efetiva de referenciais tecnológicos abrangentes, sem a criação de polêmicas e pontos de bloqueio, que certamente já trarão inúmeros benefícios para os agentes da cadeia produtiva e para a sociedade em geral.

Outro ponto a ser considerado é o da referência explícita à quem tem o direito de editar um referencial tecnológico, ou seja, quem irá defini-los. No caso da definição do PBQP-H, são citados "clientes" e "entidade de classe". Mais uma vez a referência a estas na definição foi uma boa opção, na ocasião, 
por mostrar a diversidade possível de referenciais: no caso dos "clientes", a ênfase do referencial são as especificações do produto e o controle do processo de produção, o que embasaria a relação contratante versus contratado; já no das "entidades", pensando-se na de empresas construtoras, por exemplo, são os procedimentos de execução (conforme Tabela 5), podendo-se estender aos procedimentos de uso e manutenção do edifício, visando obter subsídios para atender as especificações do produto e garantir o controle de qualidade da execução dos serviços. Como se defende a idéia francesa de ter documentos únicos, de caráter consensual entre os principais agentes da cadeia produtiva para o processo de produção de edifícios, aliado ao papel de esclarecimento que, espera-se, essa dissertação venha a ter, sugere-se que, ao menos a médio prazo, esse aposto seja suprimido.

Assim, quanto à conceituação do tema, neste trabalho, sugere-se que o termo "referenciais tecnológicos" seja entendido como:

"Documentação técnica de referência, não normativa, e de caráter consensual entre os principais agentes envolvidos na cadeia produtiva, que recomenda boas práticas para o processo de produção de edificios, abrangendo desde a etapa de planejamento, projeto, execução até uso, manutenção e pós-uso (reforma ou demolição)".

Nota-se que a definição do PBQP-H, exposta no Capítulo 2, cita que os documentos podem ser para determinadas etapas do processo de produção 'ou' para outras ("projeto, produção, instalação, manutenção 'ou' utilização do produto"), enquanto a definição apresentada nesse estudo modifica o 'ou' para 'e', no intuito de que sejam contempladas e compatibilizadas todas essas etapas para um determinado serviço ou elemento da construção, minimizando os conflitos encontrados na aplicação prática de alguns documentos distintos sobre o mesmo serviço. Essa idéia foi colocada para que a documentação seja visualizada e entendida de forma sistêmica, aceitando-se, porém, que o desenvolvimento seja evolutivo, isto é, que os documentos possam ser elaborados por "etapas" até que sejam contemplados todos os aspectos essenciais.

Por fim, ressalta-se que um aspecto negativo do conceito de referencial tecnológico não deve ser aqui esquecido: o fato de poder levar à falta ou insuficiência de estudos quanto às características específicas de um dado empreendimento, devido à sua capacidade de simplificar projetos, procedimentos de execução e controles. Portanto, atenta-se para que, mesmo de posse dos documentos técnicos de referência, servindo estes como base para a tomada de decisão, os profissionais do setor analisem cada situação, verificando se não se trata, por exemplo, de uma exceção ao documento, e fazendo as suas devidas adaptações e complementações, caso haja necessidade. 


\subsection{Quanto ao conteúdo e à estrutura dos documentos}

Primeiramente, quanto ao conteúdo, não foram estudados documentos especificamente relativos à fabricação e ao controle de materiais e componentes, ao planejamento da obra, à manutenção, ao uso e pós-uso dos edifícios; restringindo a pesquisa a documentos de especificação de produtos (projeto, desempenho) e relativos à execução da obra (procedimentos e controle do processo).

Considerando essa delimitação da pesquisa, é importante notar que alguns dos documentos estudados apesar de citar os itens relativos, por exemplo, aos serviços de execução, apresentam um conteúdo técnico de certa forma "genérico", ou seja, informam o que se deve fazer, porém não estipulam objetivamente como deve ser realizado o serviço, quais ferramentas ou equipamentos devem-se utilizar, quais aspectos técnicos devem ser considerados na execução (qualitativos e quantitativos), o que exatamente deve ser controlado durante o processo e como, o que se pretende atingir quanto ao desempenho do produto final, etc.

Além disso, muitas vezes, o conteúdo técnico não é apresentado segundo uma forma ou estrutura padrão para cada serviço ou elemento da construção. Como conseqüência, a leitura fica menos didática e o entendimento dificultado, além de a abrangência do conteúdo ficar mais aprofundada em alguns itens e mais superficial em outros.

Com relação ao conteúdo técnico, os referenciais tecnológicos podem suprir a lacuna existente no conjunto normativo nacional; porém, o conceito desses documentos pode extrapolar o abordado pela normalização técnica. Isso porque os referenciais tecnológicos podem conter aspectos administrativos, os quais não poder constar das normas técnicas ABNT, já que estas, em consonância da ISO, não permitem que nelas sejam tratadas questões contratuais. Podem ser citados, como documentos desse tipo, os DTU franceses que contêm um caderno de cláusulas administrativas e, no Brasil, por exemplo, o documento de Requisitos e Critérios Mínimos da CAIXA, contendo garantias e responsabilidades da construtora e do fabricante dos componentes e sistemas construtivos.

Quanto à estrutura dos referenciais tecnológicos, os documentos nacionais são analisados entre si e, inclusive, comparados aos Documentos Técnicos Unificados da França, que é o referencial tecnológico estrangeiro de interesse para o presente estudo. Os demais documentos estrangeiros foram apresentados e discutidos nesse trabalho somente a título de informação e conhecimento dos mesmos, visando a mostrar que em alguns países, principalmente nos desenvolvidos, os documentos técnicos de referência já são realidade, apesar de cada um ter um contexto, muitas vezes distintos, de elaboração, uso e exigência de tais documentos, bem como conteúdo e estruturação diversos. 
Assim, após a análise da estrutura dos documentos estudados, é possível observar dois modelos básicos quanto à apresentação dos serviços (ou elementos da construção) e das etapas do processo de produção dos edifícios. Dessa forma, verificou-se, basicamente, duas estruturas distintas de referenciais tecnológicos:

- a subdividida por etapas do processo de produção do empreendimento ou da obra, sendo que cada etapa contempla os diversos serviços ou elementos da construção; e

- a subdividida por serviços ou elementos da construção, sendo que para cada elemento são contempladas as diversas etapas do processo de produção do empreendimento ou da obra.

Logo, quanto ao primeiro tipo de estrutura abordado, observou-se que alguns documentos têm seu conteúdo técnico estruturado de acordo com as etapas seqüenciais do processo de produção de um empreendimento ou uma obra, ou seja, são subdivididos, por exemplo, em: aspectos gerais, como processo de contratação dos serviços; planejamento da obra; materiais; especificações de projeto; procedimentos de execução; controle do processo de execução; entrega da obra; uso e manutenção do edifício; demolição ou reforma. A Figura 11 ilustra esse tipo de estrutura, exemplificada com os temas de documentos mais aprofundados nesse trabalho: projeto, execução e controle.

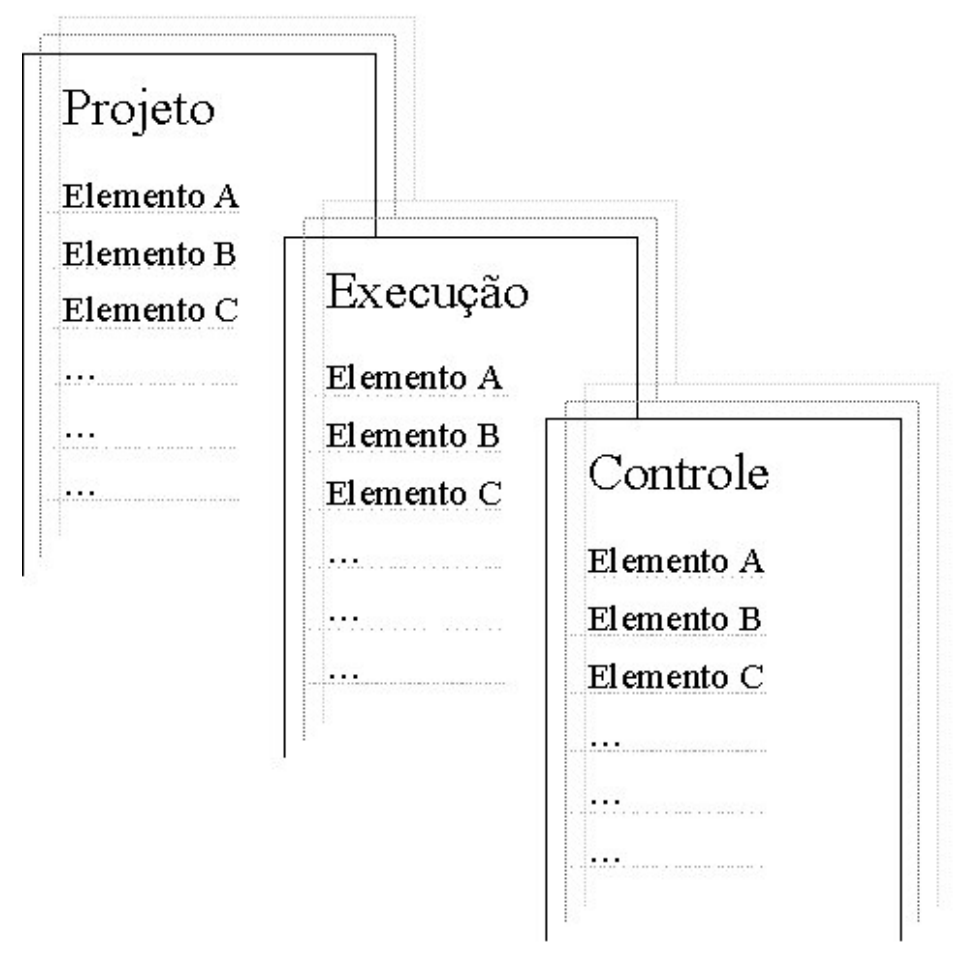

Figura 11 - Estrutura de referenciais tecnológicos subdividida por etapas do processo de produção do empreendimento ou da obra. Cada etapa contempla os diversos serviços ou elementos da construção.

Ainda com relação à Figura 11, tem-se que essas etapas podem ser consideradas em documentos separados ou como itens de um mesmo documento. Assim, um documento pode conter somente uma 
etapa ou mais, observando-se, porém, que muitas vezes não são contempladas todas as etapas para um determinado elemento da construção ou serviço. Por exemplo, a alvenaria estrutural deveria estar sendo citada no item de projeto (incluindo sua modulação, resistência, etc.), no item de materiais (especificação do bloco, traço de argamassa, etc.), no item de procedimentos de execução (como assentar os blocos, quais os equipamentos utilizados, como garantir o prumo, etc.), no item de controle do processo de execução (como verificar se o prumo está de acordo com a tolerância especificada, qual é a conformidade das espessuras das juntas entre blocos, etc.), e assim por diante.

Nesse caso, é importante que cada um dos elementos ou serviços sejam considerados em documentos ou itens referentes a todas as etapas da obra. E mais do que isso, é essencial que exista uma correlação e equivalência entre esses tipos de documentos, por exemplo, uma especificação feita no item de projeto para determinado elemento deve ser factível de acordo com o item de execução do mesmo, e um procedimento recomendado no item de execução deve ser adequadamente verificado no item de controle do processo de execução, além de ser verificado no item de controle do produto, após término de sua execução, e assim sucessivamente. Mesmo porque, muitas vezes, os profissionais que irão utilizar tais documentos são diferentes em cada uma das etapas, como projetistas, construtoras e gerenciadoras, por exemplo, e portanto, não pode haver conflitos entre os mesmos. Caso não haja essa integração entre os documentos, a incompatibilidade encontrada em seu uso, na prática, provavelmente causará não-conformidades e prejuízos na qualidade e desempenho do edifício.

Por outro lado, desde que essa integração tenha sido considerada, a estrutura em questão facilita o uso dos documentos específicos pelos agentes da cadeia produtiva, os quais são responsáveis pelas respectivas etapas do processo de produção do edifício, facilitando o seu entendimento. Por exemplo, os projetistas irão utilizar o documento de "Projeto", o qual já tem que ter sido elaborado com vistas aos mesmos. Entretanto, os projetistas não devem deixar de considerar também o conteúdo dos demais documentos.

Os tipos de referenciais tecnológicos, estudados nesse trabalho, foram definidos de acordo com essa estrutura, em: especificação de produto, procedimentos de execução e controle do processo de execução, conforme Tabela 5 do Capítulo 3.

Quanto aos documentos aqui estudados que apresentam uma estrutura similar a esta, tem-se as Práticas da SEAP subdivididas em: projeto, construção e manutenção; as antigas Práticas DASP, com normas de projeto e métodos de execução de serviços; bem como o PROCONTROL, que se divide em procedimentos para apresentação de projetos, de concepção, de execução, de "fiscalização", de programação, de orçamentação, de medição e especificações. 
Os documentos do Projeto IPT/SICCT também apresentam essa configuração, sendo estruturados em módulos de recomendações para seleção e recebimento de materiais e componentes, para elaboração e avaliação de projeto e para execução e "fiscalização" de serviços. Quanto ao uso desses documentos, segundo IPT (1984), os documentos de recomendações para o projeto, por exemplo, deveriam ser utilizados no mínimo em dois momentos do processo de produção do edifício. Primeiramente, antes de projetar os elementos e as instalações. Nesse momento, esses documentos deveriam ser incorporados às exigências de contrato de tal forma que o projetista direta ou indiretamente via a construtora tivesse acesso e conhecimento daquilo que deve projetar e apresentar, ou seja, o que seria exigido e o que deveria constar de seu projeto executivo. Posteriormente, dever-se-ia utilizá-lo na avaliação e recebimento do projeto pronto. Nessa etapa, as equipes técnicas dos agentes encarregados da avaliação e recebimento dos projetos deveriam utilizar esses documentos como roteiro de referência da qualidade daquilo que estaria sendo submetido a julgamento.

Cita-se, também, como documento de acordo com tal estrutura, o Caderno de Encargos da SUCAB, que está organizado em módulos de insumos, projetos e serviços. Os demais Cadernos de Encargos apresentam, em geral, itens de generalidades, como planejamento da obra e procedimentos de contratações; itens de materiais a empregar e equipamentos; e de procedimentos de execução da obra. Alguns, como o Caderno de Encargos do Engenheiro Paulo Costa e o Manual Técnico do DOP, apresentam, ainda, itens de orçamentação com coeficientes para composições de preços.

Existem, ainda, alguns documentos específicos para somente uma determinada etapa da obra, como é o caso, por exemplo, do Manual Técnico de Engenharia da CAIXA que apresenta condições mínimas e exigências para a etapa de projeto dos diversos elementos da construção. Pode-se citar, também, o Manual de Controle de Obras e Serviços da CDHU que é específico para a etapa de controle do processo de execução dos serviços e de alguns elementos acabados nas obras promovidas pela CDHU, apresentando as tolerâncias aceitáveis e permitidas nesse controle.

Por outro lado, quanto ao segundo tipo de estrutura dos referenciais tecnológicos, tem-se que os documentos são organizados por serviços ou elementos da construção, considerando-se que para cada um dos serviços ou elementos são contempladas todas, ou quase todas, as distintas etapas do processo de produção de um edifício, conforme ilustrado na Figura 12, a seguir. 


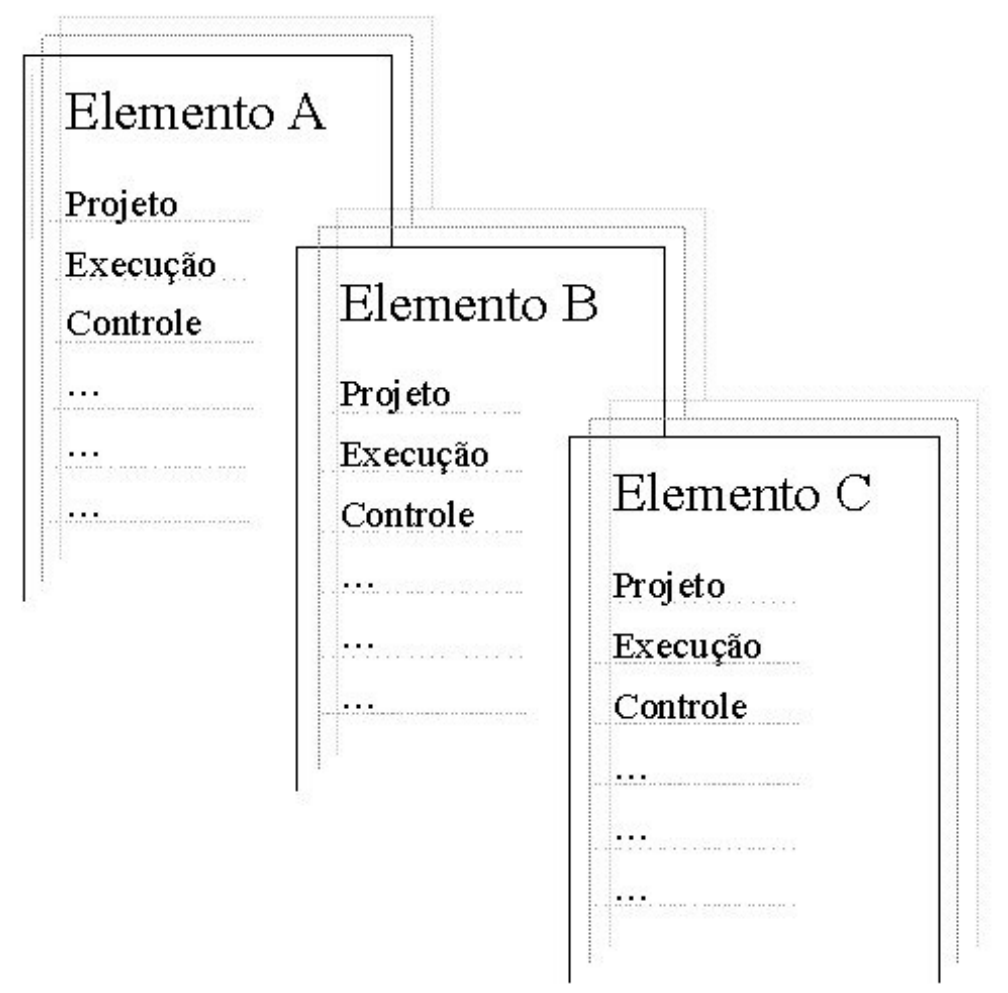

Figura 12 - Estrutura de referenciais tecnológicos subdividida por serviços ou elementos da construção. Para cada elemento são contempladas as diversas etapas do processo de produção do empreendimento ou da obra.

Segue o modelo de estruturação apresentado na Figura 12, o sistema francês de Documentos Técnicos Unificados (DTU), incluindo referenciais tecnológicos para cada serviço ou elemento da construção. Apesar de o enfoque das cláusulas técnicas desses documentos, ser dado basicamente à execução dos serviços, pode-se ainda contemplar, para o determinado elemento, regras de cálculos de projeto, especificações de materiais, controles, condições de início de uso e manutenção. Também nessa estrutura, os itens relativos a cada elemento devem ser concatenados, como o planejamento da produção com os setores de projetos, suprimentos, execução, controle e outros. Além disso, existem as cláusulas administrativas que tratam de questões contratuais.

Também de acordo com esses moldes, pode-se citar dentre os documentos estudados nesse trabalho, os de Requisitos e Critérios Mínimos da CAIXA, por exemplo. São documentos elaborados para elementos ou serviços específicos, como alvenaria estrutural, divisórias em gesso acartonado, estruturas em aço, etc. Sendo que, para cada elemento são apresentadas, exigências de desempenho, de projeto, de execução e controle de recebimento, como no caso do gesso acartonado. Além da parte técnica, tais documentos abordam aspectos contratuais, em itens relativos às garantias e responsabilidades da construtora e do fabricante dos componentes, por exemplo. Percebe-se, portanto, sua relativa semelhança aos documentos franceses, quanto ao conteúdo e estrutura dos mesmos. 
Outro exemplo é o documento da série Recomendações Técnicas HABITARE, relativo, no caso, ao revestimento de argamassa. Este documento contém boas práticas em projeto, execução e avaliação (ou controle) desse tipo de revestimento, sendo subdividido nas seguintes etapas para o serviço ou elemento em questão: projeto, planejamento, produção e conservação do revestimento de argamassa. Segundo essa estrutura e conteúdo, seria interessante que fossem feitas publicações também sobre outros serviços relevantes para a construção de edifícios.

Ainda com relação a esse segundo modelo de estrutura dos documentos, apesar da quantidade de documentos necessariamente ser maior (devido à maior quantidade de serviços existentes em relação à quantidade de etapas da obra), o conteúdo de cada documento tende a ser mais completo e com uma abordagem mais específica. A sua grande vantagem parece, no entanto, ser a facilidade na sua produção e implementação. Segundo o princípio de que a documentação seja obtida de modo consensual, é mais fácil que um tal processo se dê quando focado num serviço ou elemento da construção. Por exemplo, todos os agentes de interesse seriam mobilizados para tratarem do serviço "execução de revestimentos horizontais internos", ou mesmo acrescentando-se "em placas cerâmicas" e, para este, seriam discutidas e acordadas as exigências e critérios relativos a projeto, execução, controle, manutenção, etc.

Desse modo, e coerentemente com a definição dada em 6.2 e com o esquema da Figura 12, sugere-se, aqui, que essa estrutura seja adotada principalmente para a fase de execução dos serviços e elementos da construção, seguindo o exemplo dos DTU franceses, cujo foco do documento é o item de "prescrições relativas à execução", podendo incluir também o controle do processo de execução. Para alguns elementos também podem ser contemplados aspectos específicos de projeto. Porém, no caso de aspectos mais amplos como projetos de arquitetura, por exemplo, poder-se-ia utilizar a estrutura do primeiro modelo apresentado na Figura 11.

Assim, também de acordo com esse segundo modelo de estrutura apresentado, as informações devem ser coerentes para cada etapa de um serviço ou elemento (no mesmo documento) e para cada serviço subsequiente (nos demais documentos utilizados em um mesmo empreendimento). Cada agente específico do setor deve ter todos os documentos pertinentes aos serviços ou elementos que serão por ele contemplados na obra; por exemplo, se o projetista for realizar o projeto dos elementos A, B e C, deve estar de posse dos documentos relativos a estes, fazendo-se a leitura das especificações contidas no item de "Projeto" em cada um dos documentos, conforme mostrado em esquema ilustrativo na Figura 13. 


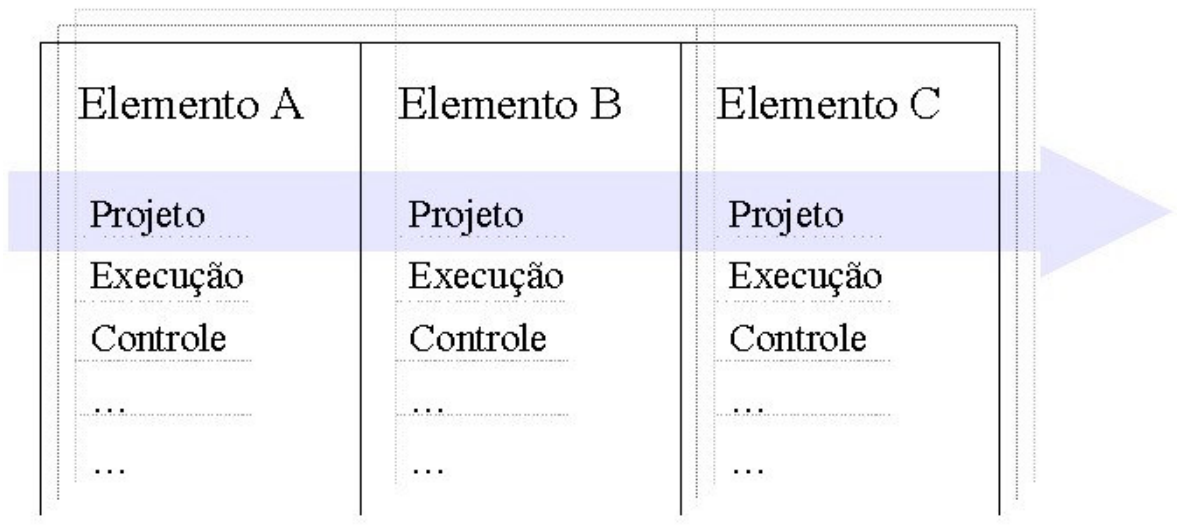

Figura 13 - Esquema ilustrativo da leitura dos referenciais tecnológicos por agentes específicos de cada etapa do processo de produção de edifícios, no caso, os projetistas.

Assim, como observado, a vantagem é que o profissional responsável pela etapa de projeto também já tem fácil acesso às informações das etapas seguintes do processo de produção do empreendimento para o determinado elemento: como será a execução, o controle, a manutenção, bem como qual será o desempenho esperado para o elemento que está sendo por ele projetado, podendo-se verificar, inclusive, a viabilidade do seu trabalho.

Uma outra análise que pode influenciar o conteúdo e a estrutura de um documento técnico de referência é saber quem são os responsáveis pela elaboração dos documentos e qual o motivo que os levou a tal elaboração, em um contexto específico. Por exemplo, dentre outros motivos os referenciais tecnológicos podem ser desenvolvidos para evitar conflitos e duplicidades, para homogeneizar boas práticas (difusão tecnológica), para formalizar e disseminar o conhecimento, para facilitar treinamentos e para auxiliar nos processos contratuais.

Por exemplo, foram vistos dois Cadernos de Encargos cujos responsáveis pelo seu desenvolvimento foram engenheiros civis, respectivamente, eng. Paulo Costa e eng. Milber Guedes. O eng. Paulo Costa foi um dos pioneiros no assunto no Brasil, tendo publicado esse documento ainda na década de $30 \mathrm{e}$ contando com a colaboração de seus colegas de trabalho. Assim, também, foi a elaboração do documento do eng. Milber Guedes, o qual possui uma versão atualizada de 2004. Percebe-se, no entanto, que o objetivo do desenvolvimento de tais referenciais tecnológicos não era realizar um consenso com o setor da construção de edifícios quanto ao conteúdo desses documentos; e sim, apenas formalizar algumas exigências, com base na experiência prática dos autores, que pudesse não só influenciar na qualidade e no desempenho das edificações, mas também e, principalmente, disseminar e socializar o conhecimento desses profissionais.

Já os Cadernos de Encargos elaborados pelos órgãos públicos, como o do Governo do Estado do Rio de Janeiro e da Prefeitura do Município de São Paulo, possuem um caráter mais contratual e de 
especificação do produto a ser exigido por tais contratantes de obras públicas. A necessidade de se especificar o que se pretende cobrar dos contratados foi provavelmente a causa da elaboração desses referenciais tecnológicos, visando à melhoria da qualidade e do desempenho das construções em cada localidade. Assim, acabam sendo, geralmente, documentos que possuem uma estrutura pouco didática, já que a disseminação do conhecimento para o setor não é o foco.

É importante, em tempo, que seja notada a diferença existente entre os Cadernos de Encargos e os documentos técnicos de procedimentos de execução, por exemplo. Os primeiros são voltados, fundamentalmente, para a especificação do produto, ainda que em boa parte deles haja uma descrição da execução. Já os procedimentos, de um manual da qualidade, por exemplo, possuem uma visão do processo e, mesmo, de controle da execução. Assim, os Cadernos de Encargos, em geral, apresentam o resultado que o contratante deseja, reunindo as obrigações do construtor, no que se refere às especificações e às normas definidas pelo contratante e pela ABNT, bem como outras de caráter administrativo. Por outro lado, os procedimentos de execução são a resposta do produtor a este objetivo, ou seja, ao que foi estipulado pelo contratante, ou ainda uma forma daquele formalizar e consolidar o seu 'saber fazer'.

Salienta-se, ainda com relação ao por quê da elaboração dos referenciais tecnológicos, o caso inserido no âmbito dos Programas da Qualidade, quanto às construções de edifícios, nos quais é importante que se tenha definido de maneira formal, ou seja, por meio de documentos técnicos de referência, as exigências e os requisitos, critérios mínimos de qualidade e de desempenho que o Estado espera das obras públicas, bem como dos serviços intermediários que levam a estas, adquirindo, deste modo, subsídios que possam ser exigidos dos responsáveis pelo processo de produção dos empreendimentos. Destaca-se, também, que somente a elaboração de um documento que formalize e consolide alguns aspectos a serem exigidos pelo agente promotor das habitações, ou das edificações em geral, não é de todo suficiente, sendo que ainda é necessário definir como será possível exigir a prática desse documento, como implantá-lo e garantir que seus requisitos sejam efetivamente cumpridos nos canteiros de obras. Mesmo assim, a elaboração de um documento como o citado já é um primeiro passo.

Em mais uma análise quanto ao conteúdo técnico dos documentos estudados, ressalta-se, ainda, a importância de se verificar a "contemporaneidade" das informações contidas nos mesmos. Alguns documentos apresentam técnicas, especificações ou procedimentos rigorosamente detalhados, inclusive especificando certos materiais e componentes, sendo que, no entanto, tais experiências e produtos já se tornaram obsoletos na prática da construção civil atualmente. Por isso, é preciso que haja uma constante atualização dos documentos técnicos de referência, incorporando inovações tecnológicas, adaptações e tendências do setor. 
Outro aspecto é o da flexibilização, para incluir práticas regionais ou locais. Esse é o caso de técnicas de execução e de materiais e componentes. Um cuidado também deve ser tomado em relação ao vocabulário técnico empregado, pois alguns termos podem não ter significado numa região, ou mesmo terem sentido diverso.

Por fim, ainda quanto ao conteúdo dos referenciais tecnológicos, poder-se-ia pensar em incluir nos documentos um tema bastante recente e discutido atualmente no país: a questão da sustentabilidade dos edifícios. A propósito, dentre os documentos estudados, a SEAP é a única que considera em suas Práticas alguns aspectos relacionadas à sustentabilidade do ambiente construído, como: "redução do desperdício", "racionalização do uso da energia", "preservação do meio ambiente", "segurança e saúde do trabalhador" e "eliminação de barreiras arquitetônicas ao acesso de deficientes físicos". Assim, não somente os princípios da sustentabilidade ambiental, mas também da econômica e da social, poderiam ser inseridos como recomendações nos documentos técnicos de referência.

Propõe-se, portanto, considerando a análise de todos os documentos estudados nesse trabalho e a experiência prática adquirida, que os referenciais tecnológicos tenham por base a estrutura apresentada no APÊNDICE B, podendo-se acrescentar, excluir ou adaptar itens e sub-itens de acordo com os elementos analisados e quando se julgar necessário.

\subsection{Quanto à elaboração e implementação dos referenciais tecnológicos: aspectos a considerar e orientações}

Ao se propor o desenvolvimento de um referencial tecnológico, deve-se primeiramente refletir sobre o contexto no qual o documento será aplicado. Qual está sendo a necessidade de sua elaboração e seu uso? Quem é o cliente que se deseja atender, isto é, qual é o público-alvo para o qual o documento está sendo destinado? Apontado o cliente, é importante conhecê-lo: quais são suas necessidades, seus objetivos, o nível de conhecimento que possuem? Quais serão as condições de aplicação desses documentos? Etc. Outro aspecto importante é saber quando serão utilizados os referenciais tecnológicos, em qual etapa da obra serão aplicados e exigidos, em uma específica ou em todo o processo de produção do edifício, por exemplo.

Além de se considerar esses aspectos, ao se elaborar um documento técnico que sirva de referência e padrão para a construção, é de suma importância que se tenha uma terminologia e uma estrutura factíveis de serem entendidas por todos os profissionais do setor, conduzindo a uma linguagem homogênea e precisa. Com relação a esse aspecto, tem-se, atualmente, o Projeto CDCON (citado no Capítulo 2), que visa, dentre outros objetivos, obter um consenso em torno de uma sistemática padronizada para terminologia aplicada às edificações. Com base nessa terminologia, aceita e inter- 
relacionada com produtos e serviços, seria possível, segundo o próprio Projeto, se implantar uma gestão de conhecimento na construção, contribuindo para que os diversos agentes da cadeia produtiva não tivessem, por exemplo, problemas de adaptação e tradução de alguns termos, o que poderia comprometer a elaboração e o entendimento dos referenciais tecnológicos.

Um outro fator importante para que os referenciais tecnológicos possam ser adotados e formalmente exigidos de forma homogênea e padronizada é ter a participação e concordância dos agentes da cadeia produtiva do setor no desenvolvimento de tais documentos. Sabe-se, no entanto, da dificuldade existente devido à quantidade e à variedade de agentes envolvidos no processo de produção de um edifício. Por exemplo, num empreendimento típico de promoção e construção de edifícios, pode-se contabilizar a participação de empreendedores / incorporadores, agentes financeiros, construtoras, fornecedores de materiais e componentes, de serviços subempreitados de obra e dos serviços de planejamento e de projeto, todos com significativas interferências e responsabilidades. Assim, o consenso não parece ser tão fácil de ser obtido, porém é preciso criar mecanismos que possam promover a sua consecução.

Quanto aos principais agentes, ou intervenientes, no processo de produção dos edifícios, Helene; Souza (1988) citaram o papel que estes assumem no processo e quais são as respectivas interferências que os mesmos têm sobre a qualidade de cada etapa da obra e do produto final, conforme foi apresentado na Tabela 3, do Capítulo 2, influenciando, inclusive, o desempenho do edifício. Portanto, os tipos de referenciais tecnológicos devem estar correlacionados aos agentes envolvidos em cada uma das etapas do processo de produção. Por exemplo, ao se elaborar um referencial tecnológico conforme o tipo de especificação do produto, devem estar envolvidos, no mínimo, os seguintes agentes: projetistas, agente financeiro, empreendedor / incorporador, construtora, gerenciadora, fabricantes, seguradora e usuário final.

Ainda quanto à elaboração do texto-base dos referenciais tecnológicos, sugere-se que também estejam envolvidas as universidades, institutos de pesquisas, entidades de defesa do consumidor, governo (representados pelo Ministério das Cidades, CDHU, SUCAB, etc.), dentre outras; uma vez que a aceitação desses documentos está diretamente relacionada, entre outros aspectos, à credibilidade dos agentes que os produz. Já quanto à condução do processo de implementação, sugere-se que esta seja feita via Programas da Qualidade, como o PBQP-H, com sustentação, inclusive financeira, via entidades setoriais ou de classe, de maior interesse. Portanto, ao se sugerir que a produção desses documentos envolva fortemente as entidades setoriais voltadas ao desenvolvimento tecnológico de materiais e componentes (como ABCP, IBS, entre outras), em conjunto com empresas do setor da construção e suas entidades representativas, assim como instituições de ensino e de pesquisa, está se 
visando abranger os principais agentes interessados da cadeia produtiva do setor, obtendo-se um consenso entre os mesmos e eliminando os conflitos na implementação dos documentos.

Além disso, outra questão relevante é como se obter esse entendimento, ou seja, considerando-se a participação de tais agentes, qual é a forma de se construir o consenso na elaboração dos referenciais tecnológicos no Brasil. Nesse âmbito, seria interessante que fosse adotado um processo similar ou baseado no modelo existente na Europa. Na França, por exemplo, o consenso é obtido junto à cadeia produtiva da construção civil, por meio de comitês. Por outro lado, se observa um modelo distinto nos EUA, onde, em geral, os Institutos, como o ICC, oferecem os referenciais tecnológicos ao mercado e os "clientes" os adotam conforme conveniência.

A partir da obtenção desse consenso entre as profissões e agentes envolvidos do setor, uma outra análise que pode ser feita é quanto à instituição, no futuro, de documentos únicos, ou seja, um sistema de documentos técnicos unificados, como na França, que fossem exigidos no Brasil. Nesse caso, outros desafios teriam que ser superados, dentre eles o de se conseguir a integração dos diferentes "Brasis" existentes, os quais possuem diferenças sociais, econômicas, físicas, climatológicas, etc. Uma outra questão, talvez ainda mais difícil do que integrar os aspectos locais a um agente específico, refere-se aos conflitos de interesse entre os próprios agentes. Hoje, para materiais e componentes, as entidades já são nacionais; para as construtoras, há a Câmara Brasileira da Indústria da Construção (CBIC); para os profissionais de projeto e gerenciamento também existem entidades nacionais, como o SINAENCO, o Instituto de Arquitetos do Brasil (IAB), a Associação Brasileira de Engenharia e Consultoria Estrutural (ABECE), dentre outras. Entretanto, o que poderia dificultar a elaboração de um documento único seria, por exemplo, a pouca flexibilidade de alguns órgãos públicos estaduais que optassem por manter suas próprias referências.

Com relação a esse modelo, no caso do Brasil, que ainda não possui os tais "códigos de práticas" a nível nacional, considera-se que, dentre os referencias tecnológicos estrangeiros apresentados, os DTU parecem ter sua adaptação ao contexto brasileiro já com um "passo a frente" dos demais, haja vista a discussão e reflexões apresentadas no item 4.9, do Capítulo 4, num processo iniciado há pelo menos cinco anos. Portanto, o estudo dessa documentação técnica de referência da França, por se tratar de um modelo eficaz e já consolidado, contribui para auxiliar na elaboração da estrutura e do conteúdo dos documentos nacionais, bem como para conhecer os mecanismos institucionais realizados para o desenvolvimento desse modelo e tentar adequá-lo ao contexto brasileiro. Apesar disso, considera-se que o modelo utilizado na Inglaterra, do NHBC (visto no item 3.1.5 do Capítulo 3), também é bastante interessante. Nesse caso, existe a ação de uma seguradora, cuja existência está diretamente vinculada ao próprio modelo, já que estes são complementares, o que poderia ser adotado no Brasil, por exemplo 
com a colaboração da CAIXA, demais bancos, companhias de seguro, Instituto de Resseguros do Brasil, dentre outros. $\mathrm{O}$ foco, aqui, poderia ser a construção habitacional.

Já com relação às experiências nacionais, tem-se que o esforço de produção de documentos técnicos de referência poderia ser facilitado a partir da busca e do estudo de conteúdos de documentos elaborados no Brasil, conforme foi visto no Capítulo 3, sendo que essa busca ainda pode, se necessário, ser mais expandida e aprofundada. Assim, também como uma contribuição desse trabalho, tem-se o aproveitamento das informações sobre os documentos técnicos de referência analisados para um desenvolvimento futuro de referenciais tecnológicos aplicados, por exemplo, a uma etapa específica da execução. Ou seja, caso sejam elaborados referenciais tecnológicos para "revestimentos de fachadas", por exemplo, algumas especificações, procedimentos ou exigências, que já foram explicitados em outros documentos levantados por essa pesquisa, podem então ser utilizados.

Nesse contexto, após o conhecimento de alguns documentos, incluindo os estrangeiros, observa-se que não é necessário idealizar algo totalmente inusitado, uma vez que já existem experiências e estas podem e devem ser aproveitadas, logicamente com suas devidas adaptações. O desafio, no entanto, é saber como partir de iniciativas isoladas e conseguir implementar uma dinâmica que leve ao estabelecimento de um modelo único de referenciais tecnológicos, contemplando os diferentes tipos existentes para cada serviço ou elemento da construção de edifícios do país, as diferentes etapas do processo de produção e sendo implantado a nível nacional.

Assim, considerando-se os estudos desenvolvidos no decorrer desse trabalho, incluindo algumas idéias apresentadas pela ANTAC (2003), sugere-se o estabelecimento de uma estrutura institucional adequada para a produção de modelos de códigos de prática e guias de práticas recomendadas, que envolvam organizações competentes, levando em conta a já citada necessidade de regionalização dos documentos, bem como a criação de mecanismos de fomento para apoiar a produção dos textos básicos. Parece ser natural que o PBQP-H possa acolher estas instâncias, tendo, no entanto, que envolver os seus dois comitês - 'Serviços e Obras' e 'Materiais e Componentes' - já que se trata de um tema que perpassa toda a cadeia produtiva.

Além disso, é importante que o processo de produção e atualização de normas técnicas seja aperfeiçoado, de forma a articulá-lo com a produção de modelos de códigos de prática e guias de práticas recomendadas. É interessante, ainda, que os responsáveis pela elaboração dos referenciais tecnológicos estudem mais modelos de código de prática e, em alguns casos, o conjunto de regulamentos e leis de outros países, principalmente aqueles relacionados a tópicos ainda em desenvolvimento no Brasil, como a eficiência energética, o desempenho ambiental e a manutenção do ambiente construído. 
Definidos os referenciais tecnológicos prioritários a serem elaborados, por exemplo de acordo com os critérios apresentados no item 6.1, salientam-se alguns aspectos quanto aos documentos propriamente ditos. Sugere-se que sejam, sempre que possível, simples, sucintos, didáticos, objetivos, adaptados à atual realidade nacional e que tenham flexibilidade para considerar especificidades locais e regionais, revisões e atualizações. Recomenda-se, ainda, que permitam considerar a adequabilidade de materiais, procedimentos, processos ou sistemas construtivos inovadores, desde que tais inovações atendam ao padrão mínimo de requisitos e critérios de desempenho exigido, contemplando-se particularmente a adaptação ao uso, a durabilidade e a manutenabilidade das edificações.

Como já citado, sugere-se, em geral, a adoção da estruturação por serviços ou elementos da construção (Figura 12), cobrindo aspectos de projeto, execução e controle, dentre outros. Assim, cada documento deve ter uma estrutura bem definida, contendo as boas práticas construtivas, algumas especificações do produto edifício focadas no desempenho esperado, os requisitos básicos relativos aos procedimentos de execução e de controle dos serviços, bem como algumas recomendações de projeto e de materiais utilizados que influenciem na qualidade dos serviços e no desempenho obra, podendo conter, também, algumas exigências contratuais. $\mathrm{Na}$ inexistência de normas ou leis e regulamentos que fixem requisitos e critérios de desempenho para edifícios de diferentes usos, o que de um modo geral ocorre no Brasil atualmente, estes teriam que ser definidos no próprio referencial. Além disso, exigências locais, por exemplo relacionadas à segurança ao fogo ou à acessibilidade, impostas por um município, desde que mais rigorosas, se superporiam ao definido no referencial.

Uma outra análise que pode ser feita é em relação aos aspectos técnicos de referência a serem exigidos nos documentos. Apesar do objetivo ser a obtenção de uma homogeneidade e um consenso no setor, padronizando alguns desses aspectos, atenta-se para que o termo "padronizar" não seja entendido de forma a "engessar" os mesmos. Por exemplo, para os procedimentos de execução dos serviços, sugerese não delimitar ou impor detalhamento excessivo que dificulte a atualização e incorporação de inovações tecnológicas advindas ao longo do tempo, e sim, se defende a idéia de documentar e formalizar a "essência" dos procedimentos de execução e controle, nesse caso, visando consolidar as ações do "saber fazer" que levam a uma obra com qualidade e desempenho adequados. Assim, não importa por exemplo se o pedreiro está pintando a parede na horizontal ou na vertical, desde que a qualidade final dessa pintura e o desempenho dessa parede sejam satisfatórios.

Desse modo, sem prejuízo à qualidade da informação, sugere-se que os documentos tenham caráter prático e conciso, já que serão dirigidos a técnicos qualificados nos respectivos assuntos. No entanto, para que possa atingir mais diretamente a mão-de-obra das fábricas e dos canteiros de obras, podem ser criadas versões de documentos com linguagem mais dirigida, com desenhos e ilustrações, etc. Além disso, todas as instruções e procedimentos têm que refletir absolutamente a atual realidade da 
cadeia produtiva, evitando-se inviabilidades técnicas ou econômicas no processo de produção do edifício.

Quanto à viabilidade e ao conhecimento técnico, conforme visto no item 3.2 do Capítulo 3, os documentos nacionais, em geral, apresentam um rico conteúdo técnico. Portanto, esse aspecto não pode ser considerado como uma dificuldade da implementação desses referenciais tecnológicos, ou seja, como o principal motivo pelo qual alguns dos documentos não obtiveram sucesso em sua implantação prática efetiva. Entretanto, não foi possível saber ao certo o por quê de não se ter conseguido essa efetividade na aplicação e exigência de alguns documentos que, pelo menos teoricamente, tinham condições de serem implementados na construção de edifícios em determinados Estados, como o Projeto IPT/SICCT em São Paulo, ou mesmo em âmbito nacional, como é o caso do PROCONTROL.

A resposta a esse questionamento não é tão fácil de se conseguir, pelo contrário. Em conversas informais com técnicos que chegaram a participar da idealização e do desenvolvimento desses trabalhos, observou-se que a efetiva aplicação dos referenciais esbarrava, freqüentemente, em questões de ordem burocrática (implicações em processos licitatórios, fiscalização e recebimento de obras), operacional (treinamento de técnicos, dimensionamento de equipes para a aplicação dos documentos) e mesmo política (interrupção ou mudança de programas de governo, limitação orçamentária), entre outros. Segundo esses técnicos também contribuiu, de forma secundária, certa deficiência na articulação da cadeia produtiva da construção civil, ocorrência de conflitos de interesses, relativa falta de preparo ou resistência do setor em absorver tais conceitos e aplicá-los na prática do dia-a-dia nas obras, dentre outras. Entretanto, são apenas hipóteses a respeito do tema, uma vez que não fazia parte do escopo desse trabalho buscar as causas pelas quais os processos foram ou não aplicados; e sim, apenas realizar um levantamento do que já foi desenvolvido e que, por algum motivo, ainda não se reconhece hoje como um verdadeiro referencial tecnológico.

Merecem destaque nessa análise, as citadas Práticas da SEAP, não só pelo seu conteúdo e estrutura mas, principalmente, pela sua importância legal, uma vez que, sendo um documento de caráter amplo e unificado no país, o conteúdo das Práticas da SEAP é legalmente exigido a nível nacional, particularmente no caso da contratação de serviços pelos diversos órgãos da União. Porém, não se tem conhecimento se o seu conteúdo é efetivamente cobrado e aplicado na prática das obras públicas de edificações, sugerindo-se, por exemplo, que este documento seja inserido oficialmente no PBQP-H.

Isso porque é possível observar que para que os profissionais e empresas de projeto, construtoras, gerenciadoras e outras, passem a adotar efetivamente os referenciais tecnológicos na prática é preciso que, dentre outras questões, se tenha um processo ou um agente "motivador". Isto é, precisam, na verdade, de algo que induza e incentive o uso de tais referenciais tecnológicos, uma vez que por si só é 
mais difícil que as empresas se conscientizem e tomem a iniciativa de implantá-los. E é aí que entra a participação do Estado, exercendo o seu poder de compra. Vale lembrar que, conforme visto na Tabela 3, no Capítulo 2, o papel do Estado no processo de produção dos edifícios é estabelecer a legislação pertinente, podendo interferir na definição da qualidade de forma geral, aprovando os projetos e sendo responsável pela punição nos casos em que há falta de qualidade. Dessa forma, portanto, é importante que a atuação do Estado estabeleça, por exemplo, maior ênfase para que o atendimento aos referenciais tecnológicos seja exigido via Programas da Qualidade voltados à construção, como itens auditáveis, sendo o cumprimento dos mesmos requerido como critério para contratação dos serviços dessas empresas.

Portanto, fica ainda a dúvida se a implementação dos referenciais tecnológicos sem a presença de um agente "forte", capaz de, pelo seu poder de compra, influenciar ou mesmo exigir o uso dos mesmos, poderá se dar de modo efetivo. A vinculação das ações definidas pelos agentes em seus Programas Setoriais da Qualidade (PSQ) às exigências dos Acordos Setoriais, para que aquelas de fato ocorram, têm sido uma prática dos Programas da Qualidade. Mas não se sabe ao certo se, atualmente, os agentes da cadeia produtiva, via suas entidades setoriais, estão suficientemente "maduros" para implementarem os referenciais tecnológicos, sem que haja "pressão" de um grande contratante (CDHU, SUCAB, etc.) ou agente financeiro (CAIXA).

Além disso, sugere-se elaborar uma sistemática de verificação e acompanhamento daquilo que está sendo executado na prática e se os critérios para avaliação e recebimento do produto acabado está sendo atendido de acordo com os referenciais tecnológicos existentes. Também se sugere a criação de um sistema de indicadores, para acompanhar o processo de implementação dos referenciais tecnológicos. Os indicadores funcionariam não somente como instrumentos gerenciais, como também para dar segurança e motivação aos agentes da cadeia produtiva, quanto às vantagens paulatinas obtidas com o sistema.

Salienta-se, no entanto, que obviamente esses documentos não prometem resolver de uma só vez todos os problemas em todas as etapas da obra, mas sim indicar as melhores práticas e recomendações que contribuam para minimizar não-conformidades e patologias nessas obras. Assim, os referenciais tecnológicos precisam ser implementados gradativamente, de forma que os sistemas e procedimentos sejam assimilados sem percalços pelos agentes envolvidos e que sejam utilizados corretamente para que tais objetivos sejam atendidos.

Portanto, quanto ao processo de produção e implementação dos referenciais tecnológicos, sugere-se que sejam cumpridas as seguintes etapas: após a realização de entrevistas com profissionais do setor e pesquisadores para se obter respostas do porquê alguns documentos não foram efetivamente implementados nas obras, procede-se à elaboração propriamente dita dos documentos, em um 
determinado contexto. São feitas, então, reuniões com agentes da cadeia produtiva para a obtenção do consenso quanto ao conteúdo dos documentos e, a seguir, efetiva-se a aplicação prática de alguns documentos em uma ou mais obras-piloto, com acompanhamento desde o início até o término do edifício. Com isso, os referenciais tecnológicos deverão ser retroalimentados a partir das considerações de ordem prática e, portanto, tais documentos devem estar abertos a sugestões, complementações e atualizações periódicas. O processo de implantação na construção de edifícios deve contar com o apoio definitivo do Estado, de seu poder de compra e da inserção nos Programas da Qualidade. Entretanto, além de engajar a ação de tais agentes da construção civil e das autoridades governamentais envolvidos no processo de desenvolvimento dos referenciais tecnológicos, é preciso que se pense em realizar treinamentos, como cursos e palestras, para os profissionais que irão, direta ou indiretamente utilizar os documentos técnicos de referência. Assim, sugere-se que seja dada priorização à capacitação e treinamento da mão-de-obra, em todos os níveis (engenheiros residentes, equipes das fábricas de materiais e componentes, mestres-de-obras, encarregados, pedreiros, etc), observando-se estratégias e cuidados especiais em relação ao treinamento da mão-de-obra terceirizada. É interessante agir principalmente na mão-de-obra responsável pela execução da obra propriamente dita, visando a que a conscientização dessas pessoas também contribua para o efetivo uso desses documentos na prática das obras.

Por fim, conclui-se que tanto as análises do conceito de referenciais tecnológicos, como de suas estruturas e conteúdos e, principalmente, as discussões e orientações aqui sugeridas contribuem para a implementação desses documentos técnicos de referência no país. Espera-se, portanto, que o cumprimento das ações propostas nessa dissertação colabore para que se consiga levar, com sucesso, o uso efetivo dos referenciais tecnológicos para o "dia-a-dia" do processo de produção dos edifícios, passando-se, então, da teoria à prática. 


\section{Capitulo 7}

\section{Considerações Finais}

Após a realização das análises e orientações a respeito dos referenciais tecnológicos, pretende-se, neste capítulo, fazer um fechamento do trabalho mostrando o atendimento aos objetivos estabelecidos e propor uma continuidade a este estudo, recomendando-se temas para trabalhos futuros.

Quanto à aplicação do conceito dos referenciais tecnológicos, conforme visto no decorrer deste trabalho, os documentos técnicos de referência podem ter um impacto bastante positivo no treinamento de projetistas, gerentes de obras e profissionais da construção civil, em geral. Conta-se também que a produção organizada desses documentos pode otimizar o esforço de elaboração de procedimentos para projeto, execução e controle de obras, atualmente muito fragmentado entre as empresas envolvidas no desenvolvimento e implementação de sistemas da qualidade. Tais documentos também podem facilitar a emissão de seguros-garantia e a elaboração de contratos, dentre outras finalidades que contribuem para a melhoria da qualidade e do desempenho dos edifícios e para a disseminação das boas práticas construtivas.

\subsection{Dos objetivos propostos}

De uma forma ampla, o principal objetivo desta dissertação era colocar em pauta um assunto que, atualmente, está sendo delineado como uma das prioridades para a construção civil no Brasil, mas que, por outro lado, ainda não tinha sistematizado efetivamente o seu conhecimento a respeito em um trabalho acadêmico. Assim, pretendia-se mostrar a importância do tema e a necessidade de seu desenvolvimento, no intuito de motivar a implementação de referenciais tecnológicos e incorporá-los à cultura das construções brasileiras.

Portanto, esse objetivo principal foi atendido como um todo, considerando-se os objetivos específicos cumpridos ao longo do trabalho. O primeiro objetivo, foi desenvolvido no Capítulo 2, com a apresentação e discussão de conceitos relativos aos referenciais tecnológicos, sua inserção na construção de edifícios e algumas interfaces, no caso, com o conceito de qualidade, desempenho e gestão do conhecimento. 
O objetivo de mostrar que já foram implementadas algumas iniciativas em relação à elaboração de documentos técnicos de referência no país, e que existem países desenvolvidos que já têm, há anos, a cultura dos códigos de práticas, foi o escopo do Capítulo 3. Nesse capítulo, foi realizado um breve levantamento do estado-da-arte de referenciais tecnológicos na construção de edifícios, analisando-se experiências estrangeiras e nacionais. Esse estudo foi descritivo e exploratório, tendo como estratégias o levantamento de dados, a análise de arquivos e uma pesquisa histórica.

Além da apresentação desses referenciais tecnológicos de forma geral, este estudo tinha o objetivo de se analisar mais detalhadamente um exemplo de modelo de documentos técnicos de referência, adotado e consolidado em um país desenvolvido e que pudesse ser adaptado ao contexto nacional perante algumas similaridades existentes com o Brasil. Assim, esse objetivo foi atendido com a realização do Capítulo 4, no qual foram estudados os Documentos Técnicos Unificados, utilizados na França. Para tanto, foram realizados um levantamento de dados e uma análise de arquivos, tratando-se de um estudo descritivo e exploratório.

Ainda tinha-se como objetivo o estudo de um documento técnico de referência que estivesse tendo uma aplicação prática, nos dias de hoje, verificando-se algumas vantagens e desvantagens, bem como a necessidade de se aprimorar tal documento, principalmente quanto ao seu conteúdo. Atingiu-se esse objetivo no desenvolvimento do Capítulo 5, ao se estudar o Manual de Controle de Obras e Serviços e o seu uso em obras habitacionais de interesse social no Estado de São Paulo. Assim, realizou-se um estudo de caso, com análise de arquivos e levantamento de dados, resultando em um estudo descritivo e explanatório.

As análises, discussões e orientações a respeito dos referenciais tecnológicos, principais objetivos desse trabalho, foram verificadas no Capítulo 6, sabendo-se, porém, que não se pretendia esgotar o assunto, mas sim realizar algumas considerações importantes e discutir aspectos de alguns documentos considerados relevantes para o estudo.

\subsection{Das recomendações para trabalhos futuros}

Como já citado anteriormente, este trabalho não esgota a pesquisa sobre os referenciais tecnológicos, primeiramente face à complexidade do assunto e depois por ser um tema que ainda precisa ser mais desenvolvido no Brasil. Por isso, sugerem-se alguns outros temas para a continuidade da pesquisa:

- proposta de alguns referenciais tecnológicos prioritários para o setor da construção de edifícios, de acordo com as orientações expostas no Capítulo 6, para determinados serviços ou elementos da construção, realizando-se ainda a validação de tal proposta, na prática, por meio de entrevistas e aplicações em obras-piloto. Para esse estudo, almejando um certo consenso, 
seria interessante realizar um projeto de pesquisa que envolvesse parcerias entre Universidades de diversos Estados (como SP, RJ, MG, SC e BA), Institutos de Pesquisas (como o IPT), com a participação de agente financeiro (como a CAIXA) e envolvendo profissionais atuantes no PBQP-H, por exemplo, por ser de âmbito nacional.

- Aprimoramento de softwares, conforme, por exemplo, o modelo que está sendo desenvolvido do Guia da Qualidade dos Processos Construtivos, enfocando as boas práticas para a produção de edifícios, desde sua concepção até seu uso, manutenção e pós-uso. Ainda no âmbito da tecnologia da informação e disseminação do conhecimento, poderiam ser realizados estudos para o aprimoramento da experiência desenvolvida na Bahia, quanto à elaboração de Cadernos de Encargos com acesso via Internet, bem como para a viabilidade de expandir essa idéia a outros Estados.

- Desenvolver uma pesquisa sobre como incluir, de forma mais marcante, a questão da sustentabilidade da construção, principalmente a questão da preservação ambiental, nos referenciais tecnológicos.

- Caso se consiga elaborar alguns referenciais tecnológicos no Brasil, obtendo-se o consenso desejável, sugere-se o desenvolvimento de um projeto para treinamento dos profissionais que irão efetivamente utilizá-los, visando à adequada implantação desses documentos técnicos. $\mathrm{O}$ estudo precisaria definir um programa de palestras e cursos práticos (incluindo principalmente a mão-de-obra responsável pela construção, propriamente dita, dos edifícios), que conseguisse levar o conhecimento expresso no papel para a aplicação prática na obra, observando-se as melhorias com relação à qualidade dos serviços e desempenho da construção de edifícios. Poderiam ser comparadas obras que, com o devido treinamento, estivessem utilizando os referenciais tecnológicos, com obras, de porte e características semelhantes, que não os utilizassem.

- Realizar uma pós-graduação "sanduiche", ou seja, incluindo parte da pesquisa realizada no exterior, por exemplo, na França, para analisar a aplicação prática dos documentos técnicos de referência, como os DTU, em obras locais, realizando um estudo de caso que contemplasse desde o início da obra (processo de contratação, concepção, projeto) até a entrega da mesma. Este estudo também poderia incluir visitas ao CSTB para o entendimento do processo de elaboração dos DTU, realizando-se entrevistas com os responsáveis por esse mecanismo. 


\section{REFERÊNCIAS BIBLIOGRÁFICAS}

AGENCE QUALITÉ CONSTRUCTION (AQC). Qualité, progressons ensemble. Agence Qualité Construction. Observatoire de la Qualité de la Construction. Bilan 1995-2005. Paris: Février 2006. $58 \mathrm{p}$.

AMORIM, S.R.L. Tecnologia, organização e produtividade na construção. 1995. 210p. Tese (Doutorado) - Universidade Federal do Rio de Janeiro, Rio de Janeiro, 1995.

. Novas tecnologias de informação e ambiente construído: realidade e potencialidades. In: SEMINÁRIO IBERO-AMERICANO DA REDE CYTED XIV.C, 4., v. 1. Anais... Capacitação e transferência de tecnologia para habitação de interesse social: em busca de novas estratégias. São Paulo, 2002.

ASSOCIAÇÃO BRASILEIRA DE NORMAS TÉCNICAS (ABNT). NBR ISO 9001:1994: Sistemas da qualidade - modelo para garantia da qualidade em projeto, desenvolvimento, produção, instalação e serviços associados. Rio de Janeiro, 1994.

Janeiro, 2000.

NBR ISO 9000:2000: Sistemas de gestão da qualidade - fundamentos e vocabulário. Rio de

NBR ISO 9001:2000: Sistemas de gestão da qualidade - requisitos. Rio de Janeiro, 2000.

NBR ISO 9004:2000: Sistemas de gestão da qualidade - diretrizes para melhoria de desempenho. Rio de Janeiro, 2000.

Projeto de Norma 02:136.01.001:2002: desempenho de edifícios habitacionais de até cinco pavimentos. Comitê Brasileiro de Construção Civil (COBRACON / CB-02), 2002. Disponível em: <http://www.cobracon.org.br>. Acesso em: 15 abr. 2005.

ASSOCIAÇÃO NACIONAL DE TECNOLOGIA DO AMBIENTE CONSTRUÍDO (ANTAC). Plano estratégico para ciência, tecnologia e inovação na área de tecnologia do ambiente construído com ênfase na construção habitacional. 2002. Disponível em:

$<$ http://www.antac.org.br/pdf/plano_estrategico.pdf>. Acesso em: 12 jun. 2005.

Cidades, ciência e tecnologia: habitação. IN: SEMINÁRIO COOPERAÇÃO BRASILFRANÇA. Rio de Janeiro, 2002. Anais... Porto Alegre : ANTAC, 2003. p.196-235.

. Boas práticas em projeto, execução e avaliação: revestimentos de argamassas. Série Recomendações Técnicas HABITARE , v. 1. Porto Alegre: Prolivros, 2005. Editores Ceotto,L.H.; Baduk,R.C.; e Nakamura,E.H. 96p. 
AUSTRALIAN BUILDING CODES BOARD (ABCB). Building Code of Australia. v.1 e v.2. Australia, 1996.

BARROS, M.M.B. Metodologia para implantação de tecnologia construtiva racionalizada na produção de edifícios. 1996. 422p. Tese (Doutorado) - Escola Politécnica da Universidade de São Paulo, São Paulo, 1996.

Projeto 00.00.11: Cooperação Técnica Bilateral Brasil / França / BID para o PBQP-H: aprovações técnicas, qualidade de laboratórios e aperfeiçoamento da normalização técnica. São Paulo, 2000. (Relatório do Estágio realizado pelo autor, documento de uso restrito)

BAZIN, M. Guide méthodologique - pour l'utilisation de textes d'inspiration DTU dans le contexte brésilien. Anexo ao Relatório Final: Décision n. M 0127 - BRESIL: Assistance pour la conception et l'élaboration des éléments constitutifs de DTU; Centre Scientifique et Technique du Bâtiment et la Direction Générale de l'Urbanisme, de l'Habitat et de la Construction, 2002. (Documento de uso restrito)

BORGES, C.A. Impacto das normas de desempenho nos processos de produção da construção civil. In: SindusCon-SP, palestra realizada em 23 set. 2004. Disponível em: <http://www.sindusconsp. com.br>. Acesso em: 27/6/2005.

CAIXA ECONÔMICA FEDERAL (CAIXA). Paredes de gesso acartonado: requisitos para financiamento pela CAIXA. 2001. 26p. Disponível em: <https://webp.caixa.gov.br/urbanizacao/ inovacoes/gesso.asp>. Acesso em: 5 jul. 2005.

Manual técnico de engenharia: orientação para apresentação de empreendimentos habitacionais do setor privado. 2002. 137 p.

Edificações habitacionais convencionais estruturadas em aço: requisitos e critérios mínimos para financiamento pela CAIXA. 2002. 16p. Disponível em: <https://webp.caixa.gov.br/urbanizacao/inovacoes/aco.asp>. Acesso em: 6 jan. 2006.

. Alvenaria estrutural - materiais, execução da estrutura e controle tecnológico:

requisitos e critérios mínimos a serem atendidos para solicitação de financiamento de edifícios em alvenaria estrutural junto à CAIXA. Prof. Dr. Fernando Henrique Sabbatini. 2003. 37p. Disponível em: <https://webp.caixa.gov.br/urbanizacao/inovacoes/alvenaria.asp>. Acesso em: 6 jan. 2006.

Sistema construtivo utilizando perfis estruturais formados a frio de aços revestidos (steel framing): requisitos e condições mínimos para financiamento pela CAIXA. 2003. 28 p. Disponível em <https://webp.caixa.gov.br/urbanizacao/inovacoes/steel_framing.asp>. Acesso em: 6 jan. 2006. 
Avaliações de sistemas construtivos e estabelecimentos se requisitos para edificações

térreas com paredes de concreto celular. Dezembro de 2003. 298 p. Disponível em

$<$ https://webp.caixa.gov.br/urbanizacao/inovacoes/concreto.asp>. Acesso em: 6/1/2006.

CARDOSO, F.F. Projeto 00.00.11: Cooperação Técnica Bilateral Brasil / França / BID para o

PBQP-H: aprovações técnicas, qualidade de laboratórios e aperfeiçoamento da normalização técnica. São Paulo, 2000. (Relatório do Estágio realizado pelo autor, documento de uso restrito)

Certificações 'setoriais' da qualidade e microempresas: o caso das empresas especializadas de construção civil. 2003. 210p. Tese (Livre Docência) - Escola Politécnica da Universidade de São Paulo, São Paulo, 2003.

CARDOSO, F.F. et al. Nível "B" do programa evolutivo QUALIHAB de certificação da qualidade: avaliação do impacto nas empresas de construção de edifícios. In: RESENDE, M.F. et al. (eds.). SIMPÓSIO BRASILEIRO DE GESTÃO DA QUALIDADE E ORGANIZAÇÃO DO TRABALHO: A COMPETITIVIDADE DA CONSTRUÇÃO CIVIL NO NOVO MILÊNIO. Recife, GEQUACIL/DPE/DEC/POLI/UPE-ANTAC, 1999. p.157-166.

Public policy instruments to encourage construction innovation: overview of the brazilian case. In: MANSEAU, A.; SEADEN, G. (edited by). INNOVATION IN CONSTRUCTION: AN INTERNATIONAL REVIEW OF PUBLIC POLICIES. Spon Press, Chapter 6, 2001. p.61-97.

CARDOSO, F.F.; VIVANCOS, A.G.; JESUS, C.N. The Qualihab experience - benefits and difficulties of a quality program in brazilian housing construction. In: CASALS, M. (edited by). CIB W99 / TG 36 INTERNATIONAL CONFERENCE ON COSTS AND BENEFITS RELATED TO QUALITY AND SAFETY AND HEALTH IN CONSTRUCTION. Proceedings... Barcelona, Spain, 2001. p.207-216.

CENTRE SCIENTIFIQUE ET TECHNIQUE DU BÂTIMENT (CSTB) ET LA DIRECTION GÉNÉRALE DE L'URBANISME, DE L'HABITAT ET DE LA CONSTRUCTION. Décision $\mathbf{n}^{\circ} \mathbf{M}$ 0127 - BRESIL : Assistance pour la conception et l'élaboration des éléments constitutifs de DTU. RAPPORT FINAL. 2002. (Documento de uso restrito)

CENTRE SCIENTIFIQUE ET TECHNIQUE DU BÂTIMENT (CSTB). Les règres techniques de la construction: CD-Reef.. v.3. France, set. 2005. CD-ROM.

CENTRO DE TECNOLOGIA DE EDIFICAÇÕES (CTE). Sistema de gestão da qualidade para empresas construtoras. São Paulo: SEBRAE, SindusCon-SP, 1994.

COMMISSION GÉNÉRALE DE NORMALISATION DU BÂTIMENT (CGNorBât). Manuel du redacteur de NF - DTU. DG 100 Mod 1. 2001. (Documento de uso restrito) 
COMPANHIA DE DESENVOLVIMENTO HABITACIONAL E URBANO DO ESTADO DE SÃO DE PAULO (CDHU). Programa QUALIHAB - Referência de fiscalização. Comitê interno da qualidade. São Paulo, CDHU, s.dt.a. 40p. (Documento de uso restrito)

. Programa QUALIHAB - Planilhas de verificação: edificações de até 2 pavimentos. Comitê interno da qualidade. São Paulo, CDHU, s.dt.b. 15p. (Documento de uso restrito)

. Programa QUALIHAB - Planilhas de verificação: edificações com mais de 2 pavimentos. Comitê interno da qualidade. São Paulo, CDHU, s.dt.c. 20p. (Documento de uso restrito)

. Programa QUALIHAB - Regimento de qualificação de sistemas do programa da qualidade da construção habitacional do Estado de São Paulo. Revisão 2. Secretaria Executiva, Comitê de Projeto e Obras (CPO), 2001. 47 p.

Programa QUALIHAB - Manual de controle de obras e serviços (MCOS): Lista de verificação e desvios admitidos. Versão 1, revisão 1. CDHU, APEOP, SindusCon-SP, SINAENCO, IPT. 46p. São Paulo: CDHU, 2002. Disponível em: <http://www.cdhu.sp.gov.br>. Anexo ao Regimento do Programa QUALIHAB. Acesso em: 10 mar. 2005.

Programa QUALIHAB - Regimento de qualificação de sistemas do programa da qualidade da construção habitacional do Estado de São Paulo. Revisão 5. Secretaria Executiva, Comitê de Projeto e Obras (CPO), 2003. 53p. Disponível em: <http://www.cdhu.sp.gov.br/ aplicacoes/documentos/regimento_qualificacao.pdf>. Acesso em: 10 mar. 2005.

CONSTRUCTION SPECIFICATIONS INSTITUTE (CSI). The project resource manual - CSI manual of practice: Preface. 2004. Disponível em <http://www.csinet.org/s_csi/docs/ 9700/9611.pdf>. Acesso em: 25 out. 2005.

COSTA, P. Caderno de encargos para a construção de edifícios. 1.ed. Rio de Janeiro: Editora Rodrigues \& Cia., 1939. 272p.

Caderno de Encargos. 8ed. Rio de Janeiro: Editora Científica, 1962. 502p.

DEPARTAMENTO DE EDIFICAÇÕES DA SECRETARIA DE SERVIÇOS E OBRAS DA PREFEITURA DO MUNICÍPIO DE SÃO PAULO (EDIF). Caderno de encargos. 1.ed. São Paulo, 1983.

DEPARTAMENTO DE EDIFÍCIOS E OBRAS PÚBLICAS DA SECRETARIA DOS SERVIÇOS E OBRAS PÚBLICAS DO GOVERNO DO ESTADO DE SÃO PAULO. Manual técnico do DOP. 1.ed. São Paulo, 1972.

Manual técnico do DOP: Tomo III - Caderno de Encargos de Edificações. 3.ed. São Paulo: Imprensa Oficial do Estado S.A (IMESP), 1976. 566 p. 
DEPARTAMENTO DE ENGENHARIA DA SECRETARIA DE OBRAS DO GOVERNO DO ESTADO DO RIO DE JANEIRO. Caderno de encargos. 1.ed. Rio de Janeiro, Niterói: Editora Diálogo Ltda., 1971. 353p.

DIVISÃO DE EDIFÍCIOS PÚBLICOS DO DEPARTAMENTO ADMINISTRATIVO DO SERVIÇO PÚBLICO (DASP). Obras de edifícios públicos: normas de projeto e métodos de execução de serviços e discriminação orçamentária. Brasil: Fundação Getúlio Vargas (FGV), 1964. 227 p.

Práticas DASP. Brasil, 1985. Disponível em: <http://www.planalto.gov.br/CCIVIL_03/ decreto/1980-1989/ D92100.htm>. Anexo ao Decreto no 92.100. Acesso em: 18 jul. 2005.

FARAH, M.F.S. Tecnologia, processo de trabalho e construção habitacional. 1992. 297p. Tese (Doutorado) - Faculdade de Filosofia, Letras e Ciências Urbanas da Universidade de São Paulo, São Paulo, 1992.

FEDERAÇÃO DAS INDÚSTRIAS DO ESTADO DE SÃO PAULO (FIESP). ConstruBusiness: acesso à moradia com qualidade de vida. In: SEMINÁRIO DA INDÚSTRIA BRASILEIRA DA CONSTRUÇÃO, 6. São Paulo, 3 out. 2005.

FEDERAÇÃO E CENTRO DAS INDÚSTRIAS DO ESTADO DE SÃO PAULO (FIESP/CIESP). Referências Fiesp n.7: agenda de política para a cadeia produtiva da construção civil. Estudo encomendado à empresa E3 Escritório de Estudos Econômicos S/C Ltda, coligada à empresa LCA Consultores. 2004. Disponível em: <http://www.fiesp.com.br/download/publicacoes_economia/ referencias7.pdf>. Acesso em: 5/5/2005.

FERREIRA, A.B.H. Novo dicionário da língua portuguesa. 3.ed., edição eletrônica, versão 5.0. Editora Positivo, 2004. CD-ROM.

FORMOSO, C.T. et al. Coletânea Habitare: normalização e certificação na construção habitacional. v.3. Capítulo 9: Contribuições para revisão da NR-18 - condições e meio ambiente de trabalho na indústria da construção. Porto Alegre, 2003. p.174-207.

GARVIN, D. Gerenciando a qualidade. Rio de Janeiro: Qualitymark Editora, 1992.

GUEDES, M.F. Caderno de encargos. 1.ed. São Paulo: Editora PINI, 1982. 204p.

Caderno de encargos. 4.ed. São Paulo: Editora PINI, 2004. 736p.

HELENE, P.R.L.; SOUZA, R. Controle da qualidade na indústria da construção civil. In: Tecnologia de Edificações. São Paulo: IPT / PINI, 1988. p.537-542. 
HENRIQUES, F.M.A. A noção de qualidade em edifícios. In: CONGRESSO NACIONAL DA CONSTRUÇÃ̃. Universidade Nova de Lisboa, Instituto Superior Técnico. Lisboa, 2001.

HINO, M.K. Emprego do conceito de desempenho para a melhoria da qualidade do projeto de empreendimentos habitacionais de interesse social. 2001. 123p. Dissertação (Mestrado) - Escola Politécnica da Universidade de São Paulo, São Paulo, 2001.

HUNT, G.P.C. Australia's performance-based building regulatory system. Austrália, 2005. Disponível em: <http://www.branz.co.nz/branzltd/pdfs/GraemeHunt.pdf>. Acesso em: 20 dez. 2005.

INSTITUTO DE PESQUISAS TECNOLÓGICAS DO ESTADO DE SÃO PAULO (IPT). Programa de controle da qualidade das construções habitacionais (PROCONTROL): critérios gerais de organização do Programa. São Paulo: IPT, 1981a. (Relatório Técnico 15.754)

Programa de controle da qualidade das construções habitacionais (PROCONTROL): Relatório Técnico de andamento do Programa. São Paulo: IPT, 1981b. (Relatório Técnico 16.199)

Programa de controle da qualidade das construções habitacionais (PROCONTROL): pré-caracterização do sistema de controle e fiscalização. São Paulo: IPT, 1982. (Relatório Técnico 16.573)

Programa de controle da qualidade das construções habitacionais (PROCONTROL): Relatório Final. São Paulo: IPT, 1983. (Relatório Técnico 17.985)

Elaboração de normas mínimas de desempenho para habitações de interesse social. São Paulo: IPT, 1995 (Relatório Técnico nº 33.800)

Estudos para o controle da qualidade dos componentes, elementos e do produto final de conjuntos habitacionais: Relatório Final. São Paulo: IPT, 1984. (Relatório Técnico 21.363)

Critérios mínimos de desempenho para habitações térreas de interesse social. São Paulo: IPT, 1998.

Conclusões preliminares do trabalho de acompanhamento técnico de obras e serviços em execução de conjuntos habitacionais da CDHU. São Paulo: IPT, 2004. (Relatório Técnico 71.474)

INTERNATIONAL CODE COUNCIL (ICC). International Building Code. Estados Unidos da América, 2000.

INTERNATIONAL CONFERENCE OF BUILDING OFFICIALS (ICBO). Uniforme Buiding Code. 3.ed., v.1 e v.2. Estados Unidos da América, Califórnia, 1994. 
IOSHIMOTO, E. Incidência de manifestações patológicas em edificações habitacionais. In: Tecnologia de Edificações. São Paulo: PINI / IPT, 1988. p.545-548.

JESUS, C.N. Implementação de programas setoriais da qualidade na construção civil: o caso das empresas construtoras no Programa QUALIHAB. 2004. 145p. Dissertação (Mestrado) - Escola Politécnica da Universidade de São Paulo, São Paulo, 2004.

JURAN, J.M.; GRYNA, F.M. Juran's quality control handbook. 4.ed. Editora McGraw-Hill, 1988.

MACHADO NETO, N.R. Gestão de conhecimento como diferencial competitivo. In: SEMINÁRIO GERENCIAMENTO DA INFORMAÇÃO NO SETOR PÚBLICO E PRIVADO, 4. Anais... Brasília, 1998.

MEKBEKIAN, G. Desenvolvimento de sistemas da qualidade para indústrias de pré-fabricados de concreto de acordo com as diretrizes da série de normas NBR ISO 9000. 1997. 161p. Dissertação (Mestrado) - Escola Politécnica da Universidade de São Paulo, São Paulo, 1997.

MELHADO, S.B. Gestão, cooperação e integração para um novo modelo voltado à qualidade do processo de projeto na construção de edifícios. 2001. 235p. Tese (Livre-Docência) - Escola Politécnica da Universidade de São Paulo, São Paulo, 2001.

MESEGUER, A. G. Controle e garantia da qualidade na construção. Tradução de Roberto J.F. Bauer; Antonio Carmona Filho; Paulo R.L. Helene. São Paulo: Editora Sinduscon-SP/Projeto/PW, 1991.

MITIDIERI FILHO, C.V. Avaliação de desempenho de componentes e elementos construtivos inovadores destinados a habitações: proposições específicas à avaliação do desempenho estrutural. 1998. 218 p. Tese (Doutorado) - Escola Politécnica da Universidade de São Paulo, São Paulo, 1998.

Projeto 00.00.11: Cooperação Técnica Bilateral Brasil / França / BID para o PBQP-H: aprovações técnicas, qualidade de laboratórios e aperfeiçoamento da normalização técnica. São Paulo, 2000. (Relatório do Estágio realizado pelo autor, documento de uso restrito)

MOTTA, C.F.A. Tecnologia e qualidade: os novos desafios para o IPT. In: SIMPÓSIO INTERNACIONAL DE SISTEMAS DE GARANTIA DA QUALIDADE NA CONSTRUÇÃO, 1. 1995. Seminário de políticas urbanas e cidadania: o desafio da habitação no Brasil. Brasília. Anais... São Paulo: IPT, 1995.

NATIONAL HOUSE-BUILDING COUNCIL (NHBC). National house-building council standards. v.1 e v.2. London: NHBC Publications Dept., 1991. 
Buildmark: the new home warranty only from NHBC. London, 1990.

NONAKA, I.; TAKEUCHI, H. Criação de conhecimento na empresa. Rio de Janeiro: Campus, 1997.

ORSI, A. Incorporação de bases externas de conhecimento: a gestão do conhecimento nas fusões e aquisições de empresas. 2003. 137p. Dissertação (Mestrado) - Faculdade de Economia, Administração e Contabilidade da Universidade de São Paulo, São Paulo, 2003.

PEREIRA, E.C. Monitoramento de normas e patentes como ferramenta para a inteligência competitiva. Apostila de curso elaborada para a Agência Paranaense de Propriedade Industrial (APPI), do Instituto de Tecnologia do Paraná (TECPAR). Curitiba, 2003. Disponível em: <http://www.tecpar.br/appi/News/Propriedade\%20industrial1.pdf>. Acesso em: 19 dez. 2005.

PERROTTI, E. Estrutura organizacional e gestão do conhecimento. 2004. 206 p. Dissertação (Mestrado) - Faculdade de Economia, Administração e Contabilidade da Universidade de São Paulo, São Paulo, 2004.

PICCHI, F.A. Sistemas da qualidade: uso em empresas de construção de edifícios. 1993. 461p. Tese (Doutorado) - Escola Politécnica da Universidade de São Paulo, São Paulo, 1993.

PROGRAMA BRASILEIRO DA QUALIDADE E PRODUTIVIDADE DA CONSTRUÇÃO HABITACIONAL (PBQP-H). Regimento do sistema de qualificação de empresas de serviços e obras (SiQ). Ministério das Cidades, Secretaria Nacional da Habitação. 2002. Disponível em: $<$ http://www.cidades.gov.br/pbqp-h/SIQ/Regimento_SIQ.pdf>. Acesso em: 20 abr. 2005.

Regimento do sistema de avaliação da conformidade de empresas de serviços e obras da construção civil - SiAC. Ministério das Cidades, Secretaria Nacional da Habitação. 2005. Disponível em: <http://www.cidades.gov.br-pbqp-h-SiAC-Regimento_SiAC_completo.pdf $>$. Acesso em: 30 jun. 2005.

REVISTA ENGENHARIA. CPOS, o braço técnico nas obras públicas. n.539. São Paulo, 2000. Disponível em: <http://www.brasilengenharia.com.br/ed539.htm>. Acesso em: 1 jul. 2005.

SABBATINI, F.H. Processo construtivo de edifícios de alvenaria estrutural sílico-calcária. 1984. 298p. Dissertação (Mestrado) - Escola Politécnica da Universidade de São Paulo, São Paulo, 1984.

Desenvolvimento de métodos, processos e sistemas construtivos: formulação e aplicação de uma metodologia. 1989. 336p. Tese (Doutorado) - Escola Politécnica da Universidade de São Paulo. 
SANCHES, P. Normalização: uma responsabilidade do setor da construção civil nacional. In: ENCONTRO NACIONAL DA INDÚSTRIA DA CONSTRUÇÃO (ENIC), 75., nov. 2003. Disponível em: <http://www.sindusconsp.com.br>. Acesso em: 27 jun. 2005.

SANTIAGO, J.R.S.J. O desenvolvimento de uma metodologia para a gestão do conhecimento em uma empresa de construção civil. 2002. 127 p. Dissertação (Mestrado) - Escola Politécnica da Universidade de São Paulo, São Paulo, 2002.

SCARDOELLI, L.S.; SILVA, M.F.S. Melhorias de qualidade e produtividade: iniciativas das empresas de construção civil. Rio Grande do Sul, Porto Alegre: SEBRAE, 1994.

SECRETARIA DE ESTADO DA ADMINISTRAÇÃO E PATRIMÔNIO (SEAP). Práticas da SEAP: projeto, construção e manutenção. Manual de obras públicas - edificações. 1997. Disponível em: <http://www.comprasnet.gov.br>. Acesso em: 10 nov. 2005.

SERVIÇO NACIONAL DE APRENDIZAGEM INDUSTRIAL DO ESTADO DO RIO DE JANEIRO (SENAI-RJ) et al. Guia da qualidade dos processos construtivos. Software em desenvolvimento. (Acesso restrito com uso de senha).

SOUZA, R. A avaliação de desempenho aplicada a novos componentes e sistemas construtivos para habitações. In: SIMPÓSIO DE APLICAÇÃO DA TECNOLOGIA DO CONCRETO, 5. Campinas, 1982.

A contribuição do conceito de desempenho para a avaliação do edifício e suas partes: aplicação às janelas de uso habitacional. 1983. 181p. Dissertação (Mestrado) - Escola Politécnica da Universidade de São Paulo, São Paulo, 1983.

Metodologia para desenvolvimento e implantação de sistemas de gestão em empresas construtoras de pequeno e médio porte. 1997. 335p. Tese (Doutorado) - Escola Politécnica da Universidade de São Paulo, São Paulo, 1997.

SUPERINTENDÊNCIA DE CONSTRUÇÕES ADMINISTRATIVAS DA BAHIA (SUCAB). Caderno de encargos da Bahia. Disponível em: <http://www.sucab.ba.gov.br/trab_tec_caderno_ encargos.asp>. Acesso em: 29/6/2005. (Acesso restrito, com uso de senha)

TEIXEIRA FILHO, J. Gerenciando conhecimento: como a empresa pode usar a memória organizacional e a inteligência competitiva no desenvolvimento de negócios. Rio de Janeiro: SENAC, 2000. 192p.

TOURINHO, M.C.L. Diretrizes para a melhoria da qualidade em empresas construtoras e incorporadoras de pequeno porte. 2001. 170 p. Dissertação (Mestrado) - Instituto de Pesquisas Tecnológicas do Estado de São Paulo, São Paulo, 2001. 
TRISTÃO, A.M.D. et al. Padrões internacionais para a troca e comunicação de dados na indústria da construção civil. In: SEMINÁRIO DE TECNOLOGIA DA INFORMAÇÃO E COMUNICAÇÃO NA CONSTRUÇÃO CIVIL (TIC), 2. Anais... São Paulo, 2005.

VIVANCOS, A.G. Estruturas organizacionais de empresas construtoras de edifícios em processo de implementação de sistemas de gestão da qualidade. 2001. 169p. Dissertação (Mestrado) Escola Politécnica da Universidade de São Paulo, São Paulo, 2001.

WEBER, M.S.C. Projeto 00.00.11: Cooperação Técnica Bilateral Brasil / França / BID para o PBQP-H: aprovações técnicas, qualidade de laboratórios e aperfeiçoamento da normalização técnica. São Paulo, 2000. (Relatório do Estágio realizado pelo autor, documento de uso restrito)

YIN, R.K. Estudo de caso: planejamento e métodos. 2. ed. Tradução de Daniel Grassi. Porto Alegre: Editora Bookman, 2001. 


\section{BIBLIOGRAFIA ADICIONAL}

ASSUMPÇÃO, J.F.P. Planejamento da produção de edifícios: um processo em evolução. Revista Qualidade na Construção, n. 14, p.25-29. São Paulo, 1999.

BANCO NACIONAL DE DESENVOLVIMENTO ECONÔMICO E SOCIAL (BNDES). Novas estimativas do modelo de geração de empregos do BNDES. Sinopse Econômica n.133, mar. 2004. Sheila Najberg e Roberto de O. Pereira. Disponível em: <http://www.bndes.gov.br/conhecimento/ estudos/estimativas.pdf>. Acesso em: 6 mai. 2005.

BARROS NETO, J.P. Proposta de um modelo de formulação de estratégias de produção para pequenas empresas de construção habitacional. 1999. 342p. Tese (Doutorado) - Faculdade de Administração da Universidade Federal do Rio Grande do Sul, Porto Alegre, 1999.

BAZIN, M. Démarche DTU - Centre Scientifique et Technique du Bâtiment (CSTB). Apresentação realizada no Rio de Janeiro, 2002. (Documento de uso restrito)

BRITISH STANDARDS INSTITUTION (BSI). BS-5628 (Part 1): Code of practice for structural use of masonry - part 1: unreinforced masonry. London, BSI, 1978.

CARDOSO, F.F. Estratégias empresariais e novas formas de racionalização da produção no setor de edificações no Brasil e na França: o ambiente do setor e as estratégias empresariais. In: ESTUDOS ECONÔMICOS DA CONSTRUÇÃO. São Paulo: SindusCon-SP, 1996. p.97-156.

CARDOSO, F.F. et al. Uma primeira avaliação do Programa QUALIHAB e de seu impacto nas empresas de construção de edifícios. In: CONGRESSO LATINO-AMERICANO TECNOLOGIA E GESTÃO NA PRODUÇÃO DE EDIFÍCIOS: SOLUÇÕES PARA O TERCEIRO MILÊNIO. Anais... v.2. São Paulo: EPUSP / PCC, 1998. p.609-618.

CARDOSO, F.F.; PINTO, C.A.P. O sistema de certificação QUALIHAB de empresas construtoras. In: INTERNATIONAL CONGRESS OF INDUSTRIAL ENGINEERING, 3. \& ENEGEP, 97: ENCONTRO NACIONAL DE ENGENHEIROS DE PRODUÇÃO, 17. ABEPROUFGRS, Gramado, 1997. p.67 (resumos) e texto integral no CD-ROM do evento.

CARDOSO, F.F.; VIVANCOS, A.G.; SILVA, F.B.; ALBUQUERQUE NETO, E.T. The Qualihab Program and the new contracts and contractual relationships between firms in Brazil. In: SERPELL, Alfredo (edited by). INFORMATION AND COMMUNICATION IN CONSTRUCTION PROCUREMENT. PUC, Santiago, 2000. Proceedings... CIB W92 Procurement System Symposium, Santiago, Chile, 2000. p. 233-247.

CENTRE SCIENTIFIQUE ET TECHNIQUE DU BÂTIMENT (CSTB). Lês Règles de Construction. Mieux lês connaître pour mieux les appliquer. Guide Pratique. Paris, 2002. 
CONSEIL INTERNATIONAL DU BÂTIMENT (CIB). Performance concept and its terminology. Rotterdam, 1975. Report n.32. Disponível em: <http://bcn.arch.ufl.edu/cib/info.htm>.

FORMOSO, C.T. Estratégias e ações prioritárias para ciência, tecnologia e inovação na área de tecnologia do ambiente construído. In: SEMINÁRIO IBERO-AMERICANO DA REDE CYTED, 4. 2002.

FRABIS, A.; AMORIM, S.R.L. Padronização de especificações de produtos para construção civil. In: SEMINÁRIO DE TECNOLOGIA DA INFORMAÇÃO E COMUNICAÇÃO NA CONSTRUÇÃO CIVIL, 2. São Paulo, 2005.

FUNDAÇÃO JOÃO PINHEIRO. Relatório déficit habitacional no Brasil 2000. Baseado no Censo Demográfico de 2000, realizado pelo Instituto Brasileiro de Geografia e Estatística (IBGE). 2000.

GROSS, J.G.K. Developments in the apllication of the performance concept in building. In: INTERNATIONAL SYMPOSIUM APPLICATIONS OF THE PERFORMANCE CONCEPT IN BUIDING, 3., Tel-Aviv, 1996. Proceedings... Tel-Aviv, NBRI/Technion, 1996. v.1.

INSTITUTO DE PESQUISAS TECNOLÓGICAS DO ESTADO DE SÃO PAULO (IPT). Formulação de critérios para avaliação de desempenho de edificações. São Paulo: IPT, 1988. (Relatório Técnico 16.277)

. Elaboração de Documentação Técnica de Referência para Projetos. São Paulo: IPT, 1996. (Relatório Técnico 34.275)

JURAN, J. M. China's ancient history oh managing for quality: part 1. Quality Progress. 1990a. p.31-35.

Juran na liderança pela qualidade: um guia para executivos. São Paulo: Editora Pioneira, $1990 b$.

MAIA, M.A.M. Organização do trabalho a partir da padronização da produção de edifícios. In: ENCONTRO NACIONAL DE TECNOLOGIA DO AMBIENTE CONSTRUÍDO. Rio de Janeiro, 1995. Qualidade e tecnologia na habitação. Anais... Rio de Janeiro: UFRJ/ANTAC, 1995. v.1, p.193198.

Histórico da qualidade na indústria: qualidade na construção civil - evolução no Brasil e no exterior. Notas de aula da disciplina PCC-5830: Qualidade na Indústria da Construção Civil I. Escola Politécnica da Universidade de São Paulo, São Paulo, 2003.

MELHADO, S.B.; SOUZA, A.L.R. A construção civil na França: primeira parte. Revista Qualidade na Construção, v.3., n.24, 2000. 
MINISTERE DE L'EQUIPEMENT, DES TRANSPORTS ET DU LOGEMENT. La construction en Europe en 1997. Paris, Direction des Affaires Économiques et Internationales, 1999.

Grands agrégats économiques de la construction en 1999. Paris: Direction des Affaires Économiques et Internationales, 2000.

PROHAB. Manuais de procedimentos para planejamento, projeto, execução e avaliação da habitação. São Paulo: Instituto de Pesquisas Tecnológicas, Convênio BNH / APEOP / IPT. Publicação n.1128. 1979.

REIS, P.F. Análise dos impactos da implementação de sistemas de gestão da qualidade nos processo de produção de pequenas e médias empresas de construção de edifícios. 1998. 253p. Dissertação (Mestrado) - Escola Politécnica da Universidade de São Paulo, São Paulo, 1998.

REVISTA DE TECNOLOGIA DA CONSTRUÇÃO (TECHNE). A versão 1.0 da habitação. São Paulo: PINI. n. 36. set./out., 1998. p.24-27.

SOUZA, R.; MITIDIERI FILHO, C.V. Avaliação de desempenho de sistemas construtivos destinados à habitação popular: conceituação e metodologia. In: Tecnologia de Edificações. São Paulo. PINI / IPT, 1988. p.139-142.

SOUZA, R.; SILVA, M.A.C. Estudo da competitividade da indústria brasileira: competitividade do complexo de materiais de construção. Nota Técnica. Campinas: Consórcio UNICAMP/UFRJ/FDC/ FUNCEX, 1993.

THOMAZ, E. Requisitos técnicos e operacionais visando a qualidade na construção de edifícios. 1999. 474p. Tese (Doutorado) - Escola Politécnica da Universidade de São Paulo, São Paulo, 1999.

TOURINHO, M.C.L; MITIDIERI FILHO, C.V. Qualidade nas pequenas incorporadoras e construtoras. Revista TÉCHNE, n.57. 2001. p 64-67.

VIVANCOS, A.G.; CARDOSO, F.F. Reflexos da implementação de sistemas de gestão da qualidade na organização e no meio ambiente de trabalho de empresas construtoras de edifícios. In:

ENCONTRO NACIONAL DE TECNOLOGIA NO AMBIENTE CONSTRUÍDO: MODERNIDADE E SUSTENTABILIDADE (ENTAC), 7. Anais... ANTAC/UEFS/UFBA/ UNEB/UPE/UNIFOR, Salvador, 2000.

YAZIGI, W. A técnica de edificar. São Paulo: SindusCon-SP, Editora PINI, 1998. 


\section{ANEXOA}

Manual de Controle de Obras e Serviços - Desvios e Tolerâncias Admitidas:

serviço de alvenaria estrutural 
Anexo A - Manual de Controle de Obras e Serviços - Desvios e Tolerâncias Admitidas: Serviço de Alvenaria Estrutural

Quadro 2 - Manual de Controle de Obras e Serviços - Desvios e Tolerâncias Admitidas: serviço de alvenaria estrutural. (Fonte: CDHU, 2002) (Continua)

\begin{tabular}{|c|c|c|c|c|c|}
\hline \multirow{3}{*}{ Serviços - Itens de Verificação } & \multirow{3}{*}{ Referência } & \multicolumn{3}{|c|}{ Parâmetros de Aceitação } & \multirow{3}{*}{ Observações } \\
\hline & & \multicolumn{2}{|c|}{ Norma } & \multirow{2}{*}{ Tolerância CDHU } & \\
\hline & & Requerido & Tolerância & & \\
\hline \multicolumn{6}{|l|}{ 3. Estrutura } \\
\hline \multicolumn{6}{|l|}{ 3.1 Alvenaria Estrutural } \\
\hline Alinhamento Vertical (Prumo) & $\begin{array}{l}\text { NBR-08798 } \\
\text { (p. 25) }\end{array}$ & $\begin{array}{l}\text { Atender ao } \\
\text { especificado }\end{array}$ & $\begin{array}{l} \pm 2 \mathrm{~mm} / \mathrm{m} \\
\pm 10 \mathrm{~mm} / \mathrm{pav} \\
\pm 25 \mathrm{~mm} \text { na altura } \\
\end{array}$ & $\begin{array}{l} \pm 2 \mathrm{~mm} / \mathrm{m} \text { em relação à altura, verificação } \\
\text { nas fachadas, máximo de } 5 \mathrm{~cm} ; \pm 15 \mathrm{~mm} / \\
\text { pavimento. }\end{array}$ & \\
\hline Alinhamento Horizontal & $\begin{array}{l}\text { NBR-08798 } \\
\text { (p. 25) }\end{array}$ & $\begin{array}{l}\text { Atender ao } \\
\text { especificado }\end{array}$ & $\begin{array}{l} \pm 2 \mathrm{~mm} / \mathrm{m} ; \\
\text { máximo: } \pm 10 \mathrm{~mm}\end{array}$ & $\begin{array}{l}5 \mathrm{~mm} / \text { régua de } 2 \mathrm{~m} \text {; máximo de } \pm 10 \mathrm{~mm} \\
\text { em relação ao comprimto total da parede }\end{array}$ & $\begin{array}{l}\text { equipamento: régua de alumínio } \\
\text { de } 2 \mathrm{~m} \text { (diferença no meio da } \\
\text { régua) }\end{array}$ \\
\hline $\begin{array}{l}\text { Nível: Respaldo de paredes no } \\
\text { mesmo Pavimento }\end{array}$ & $\begin{array}{l}\text { NBR-08798 } \\
\text { (p. 25) }\end{array}$ & $\begin{array}{l}\text { Atender ao } \\
\text { especificado }\end{array}$ & $\pm 1 \mathrm{~mm} / \mathrm{m}$ & $\begin{array}{l}\text { máximo de } 15 \mathrm{~mm} \text { entre paredes do mesmo } \\
\text { pavimento }\end{array}$ & equipamento: nível de mangueira \\
\hline Junta Horizontal Espessura & $\begin{array}{l}\text { NBR-08798 } \\
\text { (p. 25) }\end{array}$ & $10 \mathrm{~mm}$ & $\pm 3 \mathrm{~mm}$ & $-3 \mathrm{~mm},+5 \mathrm{~mm}$ & equipamento: trena metálica \\
\hline Junta Horizontal Nível & $\begin{array}{l}\text { NBR-08798 } \\
\text { (p. 25) }\end{array}$ & $\begin{array}{l}\text { Atender ao } \\
\text { especificado }\end{array}$ & $\begin{array}{l} \pm 2 \mathrm{~mm} / \mathrm{m} ; \\
\text { máximo: } \pm \\
10 \mathrm{~mm}\end{array}$ & $\begin{array}{l}5 \mathrm{~mm} / \text { régua de } 2 \mathrm{~m} \text {; } \\
\text { máximo: } \pm 10 \mathrm{~mm}\end{array}$ & equipamento: trena metálica \\
\hline Junta Vertical Espessura & $\begin{array}{l}\text { NBR-08798 } \\
\text { (p. 25) }\end{array}$ & $10 \mathrm{~mm} /$ outras & $\pm 3 \mathrm{~mm}$ ou $30 \%$ & $\begin{array}{l}-3 \mathrm{~mm},+5 \mathrm{~mm} \\
\text { exceto bloco de fechamento } \\
\text { (sem tolerância) }\end{array}$ & equipamento: trena metálica \\
\hline Pé Direito & & & & $\pm 25 \mathrm{~mm}$ & equipamento: trena metálica \\
\hline $\begin{array}{l}\text { Desvios de Planaridade: } \\
\text { Irregularidade Gradual }\end{array}$ & & & & $\begin{array}{l}\text { alvenaria sem revestimento: } 5 \mathrm{~mm} \text {; } \\
\text { alvenaria entregue com revestimento: } 8 \mathrm{~mm}\end{array}$ & $\begin{array}{l}\text { equipamento: régua de alumínio } \\
\text { de } 2 \text { m e trena metálica (diferença } \\
\text { no meio da régua) }\end{array}$ \\
\hline
\end{tabular}


Anexo A - Manual de Controle de Obras e Serviços - Desvios e Tolerâncias Admitidas: Serviço de Alvenaria Estrutural

Quadro 2 - Manual de Controle de Obras e Serviços - Desvios e Tolerâncias Admitidas: serviço de alvenaria estrutural (Fonte: CDHU, 2002). (Continuação)

\begin{tabular}{|c|c|c|c|c|c|}
\hline \multirow{3}{*}{ Serviços - Itens de Verificação } & \multirow{3}{*}{ Referência } & \multicolumn{3}{|c|}{ Parâmetros de Aceitação } & \multirow{3}{*}{ Observações } \\
\hline & & \multicolumn{2}{|c|}{ Norma } & \multirow{2}{*}{ Tolerância CDHU } & \\
\hline & & Requerido & Tolerância & & \\
\hline \multicolumn{6}{|l|}{ 3. Estrutura } \\
\hline \multicolumn{6}{|l|}{ 3.1 Alvenaria Estrutural } \\
\hline $\begin{array}{l}\text { Desvios de Planaridade: } \\
\text { Irregularidade Abrupta (dente) }\end{array}$ & & & & máximo: $5 \mathrm{~mm}$ & \\
\hline Desvio de Esquadro & & & & $\begin{array}{l}\text { máximo de } 15 \mathrm{~mm} \text { no comprimento total } \\
\text { das paredes do cômodo }\end{array}$ & $\begin{array}{l}\text { Medição no prolongamento da } \\
\text { linha - equip.: esquadro } 60 \mathrm{x} \\
\text { 80x } 100 \mathrm{~cm} \text {, trena metálica e linha }\end{array}$ \\
\hline $\begin{array}{l}\text { Abertura de Vãos (Horizontal / } \\
\text { Vertical) }\end{array}$ & $\begin{array}{l}\text { Projeto } \\
\text { Executivo }\end{array}$ & $\begin{array}{l}\text { Atender ao } \\
\text { especificado }\end{array}$ & & $-0,+20 \mathrm{~mm}$ & equipamento: trena metálica \\
\hline $\begin{array}{l}\text { Vãos - Posicionamento (Horizontal } \\
\text { / Vertical) }\end{array}$ & & & & $\pm 20 \mathrm{~mm}$ & equipamento: trena metálica \\
\hline Armação Vertical & $\begin{array}{l}\text { Projeto } \\
\text { Executivo }\end{array}$ & $\begin{array}{l}\text { Atender ao } \\
\text { especificado }\end{array}$ & & $\begin{array}{l}\text { Desvio na distância entre estribos: } \pm \\
\text { 10mm; Desvio no comprimento e } \\
\text { espaçamento dos arranques: } \pm 20 \mathrm{~mm} \text {, } \\
\text { mantendo-se no interior da célula do } \\
\text { bloco (sem "engarrafamentos") }\end{array}$ & equipamento: trena metálica \\
\hline Armação Horizontal & $\begin{array}{l}\text { Projeto } \\
\text { Executivo }\end{array}$ & $\begin{array}{l}\text { Atender ao } \\
\text { especificado }\end{array}$ & & & inspeção: visual \\
\hline Desobstrução Células Graute & & & & desobstruídas & inspeção: visual \\
\hline $\begin{array}{l}\text { Lançamento / Preenchimento Total } \\
\text { do Graute }\end{array}$ & & & & $\begin{array}{l}\text { Grauteamento cf indicação de proj., } \\
\text { altura máx.: } 1,60 \mathrm{~m} \text {; Preenchimento } \\
\text { completo da coluna, obrigatoriedade de } \\
\text { janela de inspeção no bloco inferior de } \\
\text { cada grauteamento }\end{array}$ & inspeção: visual \\
\hline Posição de Eletrodutos & \begin{tabular}{|l} 
Projeto \\
Executivo
\end{tabular} & $\begin{array}{l}\text { Atender ao } \\
\text { especificado }\end{array}$ & & no limite da alvenaria & \\
\hline Posição de Quadros e Caixas & & & & & Vide item: Instalações Elétricas \\
\hline Limpeza Final da Parede & $\mathrm{MD} / \mathrm{CDHU}$ & $\begin{array}{l}\text { Atender ao } \\
\text { especificado }\end{array}$ & & & \\
\hline
\end{tabular}




\section{APÊNDICE A}

Resumo das constatações apontadas nas vistorias às obras:

$$
\text { serviço de alvenaria estrutural }
$$




\section{OBRA A}

\section{VISTORIA 1}

Físico acumulado da obra: $\pm 15 \%$

Principais serviços em execução: fundação e alvenaria estrutural

Responsáveis pela obra presentes na vistoria: $2 \mathrm{eng}^{\circ} \mathrm{s}$ - construtora; $1 \mathrm{eng}^{\circ}$ - gerenciadora

Principais constatações para o serviço de alvenaria estrutural:

$>$ Os blocos estavam armazenados sobre pallets, a fim de se evitar o contato direto com o solo e facilitar o transporte dos mesmos; prática considerada adequada.

> Os resultados dos ensaios de resistência à compressão, consistência, absorção de água e outros, tanto dos blocos de concreto, argamassa de assentamento, quanto do graute, não estavam disponíveis na obra. Portanto, não foi possível verificar se esses ensaios estavam ou não sendo realizados.

$>$ As paredes de alvenaria estrutural dos edifícios vistoriados não apresentavam desvios de planeza (irregularidades graduais ou abruptas) que suplantassem as tolerâncias admitidas pelo MCOS.

$>$ Foram encontradas juntas verticais sem preenchimento em um dos edifícios vistoriados. Além disso, verificou-se a necessidade de se garantir a uniformidade no preenchimento de algumas juntas horizontais.

$>$ A ligação das paredes do shaft à alvenaria de vedação era realizada com a utilização de uma tela metálica a cada duas fiadas; prática considerada adequada. 


\section{OBRA A}

VISTORIA 2

Físico acumulado da obra: $\pm 50 \%$

Principais serviços em execução: alvenaria estrutural e revestimento

Responsáveis pela obra presentes na vistoria: 1 eng $^{\circ}$ - construtora e o mestre-de-obras

Principais constatações para o serviço de alvenaria estrutural:

$>$ As juntas entre os blocos da alvenaria estrutural encontravam-se com espessuras e preenchimento uniformes.

$>$ Os resultados dos ensaios de resistência à compressão, consistência, absorção de água e outros, tanto dos blocos de concreto, quanto do graute, estavam disponíveis na obra e atendiam às especificações.

$>$ Observou-se a utilização de junta em amarração entre os blocos, especialmente nas extremidades das paredes; prática considerada adequada.

> A ligação das paredes do shaft à alvenaria de vedação era realizada com a utilização de uma tela metálica a cada duas fiadas; prática considerada adequada.

$>$ As células dos blocos de concreto que compõem as ombreiras das portas foram grauteadas, buscando assim maior segurança / resistência para aparafusar os marcos das portas nas ombreiras (alvenaria); prática considerada adequada.

$>$ Alguns blocos de concreto estavam sendo armazenados sobre pallets, a fim de evitar o contato direto com o solo e facilitar o transporte dos mesmos; prática considerada adequada. Entretanto alguns blocos estavam diretamente sobre o solo, sendo recomendável que esses fossem armazenados sobre plataformas. 


\section{OBRA B}

\section{VISTORIA 1}

Físico acumulado da obra: $\pm 15 \%$

Principais serviços em execução: alvenaria estrutural

Responsáveis pela obra presentes na vistoria: 1 eng $^{\circ}$ - construtora; 1 encarregado (obra)

Principais constatações para o serviço de alvenaria estrutural:

$>$ Utilização de junta em amarração entre os blocos; prática considerada adequada. No entanto, algumas 'pastilhas' estavam com juntas horizontais irregulares.

$>$ Juntas horizontais mal preenchidas e com espessuras não uniformes, suplantando as tolerâncias indicadas no MCOS, em três dos edifícios vistoriados.

> As juntas verticais não tinham preenchimento (junta seca), o que poderia repercutir em um menor desempenho da alvenaria frente à ação de cargas laterais, resistência ao fogo, isolação acústica e estanqueidade.

> Foram observadas fissuras em alguns blocos de concreto das paredes estruturais (externas e internas) de um dos edifícios vistoriados. Tais fissuras podiam ser provenientes da qualidade dos blocos ou do manuseio / transporte inadequado dos mesmos. Recomenda-se maior controle na fabricação dos blocos estruturais no canteiro, evitando-se o emprego de blocos fissurados e também de blocos "verdes" (com insuficiência de cura), o que poderia levar à posterior fissuração das alvenarias.

$>$ Os blocos, no período de cura (dois dias), eram armazenados em local descoberto, e estavam sendo umedecidos com mangueira, durante um intervalo que permitia secagem das peças, especialmente, em dias com elevada temperatura e baixo teor de umidade. Após a fabricação, esses blocos deveriam permanecer úmidos (imersos em água ou cobertos com lona plástica), evitando-se perda de água e, conseqüentemente, retração nas primeiras idades.

> Os blocos estavam sendo armazenados diretamente sobre o solo. Seria recomendável que os blocos fossem armazenados sobre plataformas, a fim de se evitar contato com o solo, impedindo que sujassem ou tornassem-se úmidos.

$>$ Alguns blocos apresentavam diferenças entre suas texturas (uns mais rugosos outros menos), decorrentes, talvez, da utilização de britas com dimensões diferentes, o que podia gerar lotes de blocos com características não similares. 


\section{OBRA B}

VISTORIA 2

Físico acumulado da obra: $\pm 70 \%$

Principais serviços em execução: alvenaria estrutural e revestimento

Responsáveis pela obra presentes na vistoria: 1 eng $^{\circ}$ - construtora

Principais constatações para o serviço de alvenaria estrutural:

$>$ Foi implantada bomba d'água para melhorar o umedecimento dos blocos durante o período de cura. Ação corretiva para a constatação feita na primeira vistoria.

$>$ Os blocos encontravam-se armazenados sobre lastro de brita / pedrisco. Ação corretiva para a constatação feita na primeira vistoria.

$>$ As juntas verticais das paredes de fachada continuavam sem preenchimento, conforme especificação de projeto (junta seca).

$>$ As paredes da fachada de um dos edifícios vistoriados encontravam-se com desvio de alinhamento vertical (prumo e planeza) na região das lajes, em razão das abas laterais das fôrmas das lajes terem aberto na etapa de concretagem. Tais desvios deveriam ser corrigidos (apicoar o concreto da borda da laje), antes da aplicação do revestimento.

$>$ Observaram-se destacamentos nos encontros entre os guarda-corpos em alvenarias da sacada de circulação e as paredes de alvenaria estrutural do $1^{\circ}$ pavimento de um dos edifícios vistoriados.

$>$ Foram observadas fissuras na extremidade dos vãos das janelas dos banheiros dos Centros de Apoio Comunitário de todos os edifícios vistoriados, em razão da ausência de contra-verga nessas janelas. Segundo informação da construtora, as paredes onde se localizam essas janelas seriam quebradas para introdução de contra-vergas.

$>$ Os eletrodutos foram adequadamente embutidos nas paredes estruturais. 


\section{OBRA C}

\section{VISTORIA 1}

Físico acumulado da obra: $\pm 16 \%$

Principais serviços em execução: alvenaria estrutural

Responsáveis pela obra presentes na vistoria: 1 eng $^{\circ}$ - construtora e o mestre-de-obra

Principais constatações para o serviço de alvenaria estrutural:

$>$ Os blocos estruturais em concreto estavam armazenados sobre pallets de madeira; prática considerada aceitável.

> Foi realizado ensaio de graute para determinação da resistência mecânica do mesmo, porém não foi analisada sua consistência (slump test). O graute devia apresentar consistência adequada para que toda a seção da célula vazia do bloco seja preenchida.

$>$ As juntas horizontais entre componentes não estavam preenchidas em diversos pontos das paredes de dois dos edifícios vistoriados. As juntas verticais eram 'juntas secas', ou seja, sem preenchimento de argamassa, devendo-se tomar os cuidados já apontados para a Obra B.

$>$ Foram constatadas fissuras em alguns blocos nas paredes de todos os edifícios vistoriados.

$>$ Observaram-se quebras para a passagem dos eletrodutos em algumas paredes que suplantavam as tolerâncias do MCOS.

$>$ Existiam armaduras expostas na maior parte das contra-vergas das janelas de dois dos edifícios vistoriados.

$>$ Segundo informações da construtora, o grauteamento das alvenarias foi realizado somente na última fiada de cada pavimento, impedindo saber se as células dos blocos estruturais foram convenientemente preenchidas. Ressalta-se que o MCOS recomenda grautear até uma altura máxima de $1,60 \mathrm{~m}$, com preenchimento completo da coluna e obrigatoriedade de janela de inspeção nos blocos inferiores de cada grauteamento.

> Os blocos canaletas armazenados no canteiro apresentavam desvios significativos em relação às suas formas geométricas. Esses desvios, provavelmente, eram decorrentes do controle inadequado na etapa de fabricação.

$>$ Foi constatado que os blocos utilizados nas paredes dos apartamentos vistoriados não se apresentavam homogêneos. A homogeneidade da base (alvenaria) visa assegurar as mesmas condições de aderência em toda a extensão de aplicação do revestimento, evitando a ocorrência de superfícies com capacidade de absorção ou texturas diferenciadas em um mesmo pano de alvenaria.

> Foram verificadas falhas no projeto de modulação da alvenaria, quanto à espessura das juntas verticais (algumas maiores do que o recomendado). 


\section{OBRA C}

\section{VISTORIA 2}

Físico acumulado da obra: $\pm 50 \%$

Principais serviços em execução: alvenaria estrutural e revestimento

Responsáveis pela obra presentes na vistoria: $1 \mathrm{eng}^{\circ}$ - construtora

Principais constatações para o serviço de alvenaria estrutural:

$>$ Foram encontradas, novamente, fissuras em blocos-canaleta armazenados no canteiro.

$>$ As juntas verticais continuavam não preenchidas, entretanto, em relação à primeira vistoria, as irregularidades das espessuras das juntas entre componentes foram minimizadas.

$>$ Constatou-se, como já visto na primeira vistoria, a falta de homogeneidade dos blocos de concreto tanto em paredes internas quanto de fachadas.

$>$ Os ensaios de consistência do graute ainda não haviam sido realizados.

$>$ As juntas secas entre os blocos de concreto das paredes internas aos apartamentos estavam sendo preenchidas com argamassa para viabilizar a aplicação de revestimento de gesso sobre a alvenaria. No caso das paredes de fachada, as juntas secas com espessuras que ultrapassam os limites de tolerância do MCOS também estão sendo preenchidas, a fim de viabilizar a aplicação do chapisco e, posteriormente, do emboço. Práticas consideradas adequadas.

$>$ Foram observados, em um dos edifícios vistoriados, rasgos e quebras excessivas nos blocos de concreto que constituem os requadros das portas.

$>$ Verificou-se, segundo a análise dos resultados de ensaio da resistência à compressão das argamassas de assentamento, que essa resistência não se encontrava conforme especificação de projeto.

> Para a ligação entre as paredes de vedação e as paredes estruturais estava sendo utilizada tela metálica a cada duas fiadas; prática considerada adequada se essas telas estiverem adequadamente fixadas.

$>$ Observou-se que foram utilizadas contravergas pré-moldadas de concreto nas janelas do banheiro, com comprimento limitado à largura do vão. Nessas condições, as contravergas não têm capacidade de redistribuir tensões que se concentram nos vértices inferiores das aberturas, sendo desejável que as mesmas ultrapassem em pelo menos $25 \mathrm{~cm}$ cada lado do vão.

$>$ Os blocos cerâmicos estavam sendo armazenados sobre plataforma de madeira; prática considerada adequada. 


\section{OBRA D}

\section{VISTORIA 1}

Físico acumulado da obra: $\pm 20 \%$

Principais serviços em execução: fundação e alvenaria estrutural

Responsáveis pela obra presentes na vistoria: $3 \mathrm{eng}^{\circ} \mathrm{s}$ - construtora, $1 \mathrm{eng}^{\circ}$ - gerenciadora

Principais constatações para o serviço de alvenaria estrutural:

$>$ As paredes apresentavam janelas de inspeção sob as colunas grauteadas (células vazias dos blocos) da alvenaria estrutural; prática considerada adequada.

$>$ As juntas entre componentes (blocos em concreto), tanto vertical quanto horizontal, apresentavam-se com espessuras não uniformes.

> Foram verificados blocos fissurados ou quebrados em algumas paredes, principalmente os blocos-canaleta sobre as vergas de porta, podendo ser em razão do manuseio / transporte inadequado ou do próprio carregamento da estrutura. Constataram-se quebras e trincas, também, nos blocos estruturais na linha de passagem dos eletrodutos, em todos os apartamentos vistoriados.

$>$ Observou-se falta de homogeneidade entre blocos que compunham algumas paredes, principalmente quanto às diferentes texturas, podendo influenciar no comportamento de aderência entre a base e o revestimento. Segundo informação da construtora, alguns blocos foram comprados de fornecedores externos e outros fabricados na obra.

$>$ Foram utilizadas juntas a prumo entre os blocos na extremidade das paredes da fachada, conforme especificação de projeto, utilizando-se ganchos em formato "U" e estribos a cada 3 fiadas da alvenaria. Porém, ainda assim, é possível ocorrerem destacamentos no local. Recomenda-se utilizar tela de galinheiro antes da aplicação do revestimento, e realizar uma retroalimentação dos projetos inserindo juntas 'em amarração' e não 'a prumo'.

> A cura dos blocos de concreto fabricados no canteiro de obras estava sendo realizada de maneira inadequada: blocos umedecidos com mangueira e armazenados em local descoberto. Ver recomendações e cuidados citados na Obra B.

$>$ Os blocos de concreto estavam sendo armazenados diretamente sobre o solo. No entanto, seria recomendável estarem sobre plataformas para não danificá-los. Além disso, observou-se a utilização inadequada de blocos como escoramento de fôrmas na execução das vergas.

$>$ Não foram constatados relatórios de ensaios referentes à retração e à absorção de água dos blocos de concreto. Esses ensaios são importantes para avaliar a qualidade do bloco e influenciam no comportamento do revestimento aplicado sobre a alvenaria.

$>$ Verificou-se que os resultados dos ensaios de resistência à compressão da argamassa de assentamento atendem às especificações dos projetos fornecidos pela CDHU. Porém, não havia relatórios de ensaios de retenção de água e teor de ar incorporado. 


\section{OBRA D}

\section{VISTORIA 2}

Físico acumulado da obra: $\pm 50 \%$

Principais serviços em execução: alvenaria estrutural e revestimento

Responsáveis pela obra presentes na vistoria: 1 eng $^{\circ}$ - construtora e o mestre-de-obra

Principais constatações para o serviço de alvenaria estrutural:

$>$ Em relação à vistoria anterior, foram constatados, novamente, os seguintes itens:

- juntas a prumo nas extremidades das paredes de fachada e entre paredes estruturais e de vedação;

- juntas entre blocos com preenchimento irregular;

- cura inadequada dos blocos;

- falta de homogeneidade (textura) entre os blocos;

- armazenamento inadequado dos blocos; e

- quebras excessivas nas paredes para passagem de eletrodutos.

$>$ Foi observada, em alguns dos apartamentos vistoriados, a ausência de ganchos ou ferros tipo 'cabelo' na ligação entre a parede estrutural e a parede do shaft do banheiro, o que podia agravar a ocorrência de destacamentos nessa região. Recomenda-se adotar tela de viveiro no local, antes da aplicação do revestimento.

$>$ Observou-se, em algumas paredes dos apartamentos que os blocos de concreto apresentavam diferentes texturas, podendo influenciar na aderência entre a base e o revestimento.

$>$ Verificou-se a formação de eflorescências nos blocos estruturais nas paredes de alguns dos apartamentos vistoriados, o que prejudicar a aderência do revestimento no substrato.

$>$ Não foram realizados ensaios referentes à retenção de água e teor de ar incorporado para a argamassa de assentamento. Quanto aos ensaios de graute, os resultados de resistência à compressão aos 28 dias foram inferiores aos especificados em projeto. Recomenda-se o parecer do calculista sobre essa não-conformidade.

$>$ Constataram-se quebras e trincas nos blocos de vedação na linha de passagem das tubulações de hidráulica e elétrica de alguns dos apartamentos vistoriados. Recomenda-se a utilização de serra de disco (tipo "maquita") na execução de cortes para passagem de tubulações.

$>$ Foram verificadas, ainda, armaduras expostas na verga da janela do banheiro de um dos apartamentos vistoriados. 


\section{OBRA E}

\section{VISTORIA 1}

Físico acumulado da obra: $\pm 9 \%$

Principais serviços em execução: fundação e alvenaria estrutural

Responsáveis pela obra presentes na vistoria: $2 \mathrm{eng}^{\circ} \mathrm{s}$ - construtora; $1 \mathrm{eng}^{\circ}$ - gerenciadora

Principais constatações para o serviço de alvenaria estrutural:

$>$ Os blocos de concreto não tinham aparência homogênea e apresentavam dimensões de agregado maiores do que o recomendado pela NBR 6136: "Bloco vazado de concreto simples para alvenaria estrutural".

$>$ Foram utilizadas juntas 'em amarração' entre os blocos de concreto, exceto no encontro entre paredes de fachada, onde se constituíram juntas 'a prumo' em toda a altura do edifício. Para evitar destacamentos entre as paredes em função de movimentações higrotérmicas foram utilizados estribos de $6,3 \mathrm{~mm}$ de diâmetro entre as paredes a cada três fiadas, conforme recomendação de projeto. Cabem as recomendações e cuidados observados na Obra D.

$>$ Observou-se que as juntas entre os blocos de concreto, especialmente as juntas verticais, não se encontravam com espessuras uniformes.

$>$ Os blocos de concreto estavam sendo fabricados no próprio canteiro de obra por uma empresa terceirizada. Foram verificados blocos com fissuras nas pilhas de armazenamento.

$>$ Os blocos de concreto estavam sendo armazenados diretamente sobre o solo, sob o risco de tornarem-se sujos e úmidos.

$>$ Foram verificados problemas na etapa de cura dos blocos fabricados no canteiro, não havendo controle rigoroso do tempo e do tipo de cura dos blocos. Os cuidados e recomendações são os mesmos citados para a Obra B.

$>$ Constatou-se que não estava sendo realizado ensaio para analisar a consistência do graute. Cabe salientar que o MCOS, estabelece que o graute deve ter consistência mínima de $15 \pm 2 \mathrm{~cm}$, ideal para preencher as células dos blocos e evitar "vazios".

> A ligação entre as paredes estruturais e de vedação podia ser considerada adequada, uma vez que foi utilizado estribo ou ferro cabelo entre as paredes a cada três fiadas da alvenaria. 


\section{OBRA E}

\section{VISTORIA 2}

Físico acumulado da obra: $\pm 60 \%$

Principais serviços em execução: alvenaria estrutural e revestimento

Responsáveis pela obra presentes na vistoria: $1 \mathrm{eng}^{\circ}$ - construtora

Principais constatações para o serviço de alvenaria estrutural:

$>$ Foram encontradas fissuras nos blocos de algumas paredes de vedação.

$>$ Como visto na primeira vistoria, a obra não possui ensaios de graute referente à, consistência (slump), porém foram realizados ensaios de resistência à compressão.

$>$ Os blocos encontram-se armazenados sobre lastro de brita. Prática que pode ser considerada adequada, sendo esta uma ação corretiva da primeira vistoria.

> Continuavam sendo utilizadas juntas a prumo encontro entre paredes de fachada, conforme recomendação de projeto, possibilitando a ocorrência de destacamentos. Os cuidados e recomendações estão apresentados na Obra D.

$>$ Foram observadas quebras excessivas nas paredes estruturais de um dos apartamentos vistoriados. Nessas regiões é recomendável utilizar tela de galinheiro, antes da aplicação do revestimento, para que sejam evitadas fissuras.

$>$ As juntas entre blocos apresentavam-se com espessuras não-uniformes e preenchimento irregular em dois dos edifícios vistoriados.

$>$ Os blocos das paredes de alguns dos apartamentos vistoriados não se encontravam com superfície homogênea, cabendo as mesmas recomendações feitas para a Obra C.

$>$ Os blocos de concreto estavam sendo fabricados no canteiro, com procedimento de cura inadequados que podiam prejudicar a qualidade e o desempenho dos mesmos. As recomendações a serem seguidas foram apresentadas para a Obra B.

$>$ Verificou-se, que alguns blocos que constituíam a verga da janela do banheiro de um dos apartamentos vistoriados encontravam-se quebrados. 


\section{APÊNDICE B}

Proposta de base para estrutura de um modelo de documento técnico de referência para a construção de edifícios 


\section{PROPOSTA DE BASE PARA ESTRUTURA DE UM MODELO DE DOCUMENTO TÉCNICO DE REFERÊNCIA PARA A CONSTRUÇÃO DE EDIFÍCIOS}

\section{1 - Introdução e contexto}

Citar aspectos relevantes para o adequado entendimento do documento técnico de referência, bem como do contexto no qual está inserido. Apresentar sub-itens como:

\subsection{Objetivo}

Deixar claro o que se pretende atingir com o uso do documento e qual o resultado esperado.

\subsection{Escopo da aplicação}

Delinear onde o documento pode ser utilizado e quando pode ser aplicado, citando situações e ocasiões específicas de uso.

\subsection{Restrições / Limitações}

Explicitar as exceções e particularidades a serem consideradas, principalmente quanto à aplicação e abrangência do documento.

\subsection{Definições e Terminologia}

Termos técnicos ou expressões específicas que precisam ser homogeneizados e que são importantes para a correta interpretação do documento. Caso já exista uma definição em norma técnica nacional, esta deve ser citada juntamente com sua fonte.

\section{2 - Etapa de projeto}

Devem ser apresentados os aspectos essenciais que devem constar de um projeto de edifícios que visem à garantia da qualidade e ao atendimento ao desempenho requerido.

\subsection{Exigências técnicas de projeto}

Aspectos qualitativos e quantitativos que colaborem para a execução de um bom projeto do componente, elemento ou sistema em questão. Podem ser estabelecidas diretrizes para desenvolvimento, análise e aprovação do projeto. Deve-se exigir o nível de detalhamento, a compatibilidade das soluções e a sua construtibilidade. Caso se pretenda adotar princípios de sustentabilidade, destacando-se o foco ambiental, algumas exigências também devem ser consideradas nessa etapa.

\subsection{Requisitos e critérios de desempenho}

Citar o desempenho esperado para o produto, com o intuito que o seu projeto já considere as características necessárias para tal atendimento. Adotar, caso existam, requisitos e critérios normalizados, principalmente considerando a norma técnica nacional de desempenho (em fase de elaboração), devendo-se atentar à durabilidade e à manutenabilidade do componente, elemento ou sistema. 


\section{3 - Etapa de seleção de materiais}

Apresentar dados suficientes para que materiais com qualidade possam ser selecionados.

\subsection{Especificação dos materiais}

Definir as características exigidas para todos os materiais que compõem o componente, elemento ou sistema construtivo em questão, citando as normas técnicas correspondentes. Caso não exista normalização para o material, deve-se apresentar uma descrição precisa dos ensaios que permitirão aceitar ou rejeitar o seu fornecimento (ver item 3.3).

\subsection{Materiais qualificados}

Caso já existam materiais qualificados no Programa da Qualidade relativo ao determinado componente, elemento, ou sistema, desde que estejam de acordo com as exigências adotadas pelo contratante da obra, aqui estes podem ser citados como sendo recomendados ao uso.

\section{$\underline{3.3 \text { Ensaios laboratoriais }}$}

Citar os ensaios que devem ser feitos para comprovar a qualidade e garantir o desempenho do material, caso este não esteja qualificado no respectivo Programa da Qualidade, relacionando as normas técnicas adotadas (de requisitos e métodos de ensaios). Somente caso não exista normalização vigente, os requisitos e procedimentos de ensaios devem ser descritos. Definir a periodicidade da realização do ensaio que deve ser exigida.

\subsection{Recebimento do material em obra}

Citar as instruções para o recebimento de materiais nos canteiros de obras, incluindo produtos qualificados, certificados ou sem nenhum desses processos (prevendo-se o controle adequado para este último caso). Definir os critérios para avaliação da conformidade desses materiais como formação de lotes para ensaios, análises por amostragens, inspeção visual, controles ou ensaios expeditos, etc. Caso já exista definição em normas técnicas, somente citar a norma a ser adotada.

\section{4 - Etapa de execução}

Aqui são citadas as melhores práticas construtivas, definidas em conjunto entre os profissionais do meio acadêmico e os que têm experiência prática em obras.

\subsection{Procedimentos de execução}

Devem ser citados apenas os aspectos essenciais para a boa execução do serviço ou elemento, não devendo ser por demais prescritivos ou rígidos. Não se deve ater a descrever minuciosamente o "como executar", sendo este um passo determinado pelas próprias empresas, desde que o desempenho final do produto seja garantido. São recomendações para que o modo de execução tenha qualidade e, portanto o produto obtido também a tenha; devendo ser respeitadas as exigências colocadas no item 2 (Etapa de Projeto). Quando o serviço objeto do documento for composto por vários sub-serviços independentes, pode-se dividir este item em sub-itens, sendo cada um relativo a um sub-serviço. 


\subsection{Capacitação da mão-de-obra}

Podem ser citadas determinadas características exigidas da mão-de-obra que vai executar o serviço ou elemento da construção, além da necessidade de capacitação técnica específica e treinamentos quando for o caso, a fim de que os profissionais estejam aptos a executar o que está sendo prescrito.

\subsection{Controle do processo de execução}

Definir como será feito o controle, estipulando os critérios e a amostragem para análise. O controle deve ser feito verificando-se o cumprimento de determinadas prescrições relativas à execução, abordadas no sub-item 4.1. Definir todas as tolerâncias e desvios aceitáveis durante o processo de execução. Citar quem fará o controle, qual a periodicidade das vistorias e inspeções e qual deve ser o procedimento caso sejam constatadas não-conformidades nessa etapa. (Pode-se relembrar aqui que as não-conformidades devem ser anotadas para retroalimentar os procedimentos de execução.)

\section{5 - Etapa de entrega do elemento ou serviço}

Definir os requisitos de controle e critérios de recebimento do produto acabado, especificando as providências a serem tomadas caso verifique-se o não-atendimento aos mesmos.

\section{6 - Etapa de uso}

Estabelecer procedimentos para o uso adequado do elemento e, inclusive, recomendações para a sua manutenção e reforma.

\section{7 - Garantias e Responsabilidades}

Podem ser colocados aspectos administrativos e contratuais, como por exemplo, períodos de garantia e direitos e deveres dos principais responsáveis em cada uma das etapas citadas anteriormente.

\section{8 - Bibliografias de referência}

Citar as referências técnicas, normativas ou não, que foram utilizadas para a elaboração do documento e que deverão ser adotadas na prática. As referências também devem ser citadas nos seus respectivos itens ou sub-itens. 